UNIVERSIDADE DE SÃO PAULO:

FACULDADE DE FILOSOFIA, LETRAS E CIÊNCIAS HUMANAS

DEPARTAMENTO DE FILOSOFIA

\title{
Pintura e fotografia (Andy Warhol e Gerhard Richter).
}

(Versão Corrigida)

Tiago dos Santos Mesquita

Tese apresentada ao Programa de PósGraduação do Departamento de Filosofia da Faculdade de Filosofia, Letras e Ciências Humanas da Universidade de São Paulo, para a obtenção do título de Doutor

Orientador: Prof. Dr. Lorenzo Mammì

São Paulo, 2017 
Autorizo a reprodução e divulgação total ou parcial deste trabalho, por qualquer meio convencional ou eletrônico, para fins de estudo e pesquisa, desde que citada a fonte.

Catalogação na Publicação

Serviço de Biblioteca e Documentação

Faculdade de Filosofia, Letras e Ciências Humanas da Universidade de São Paulo

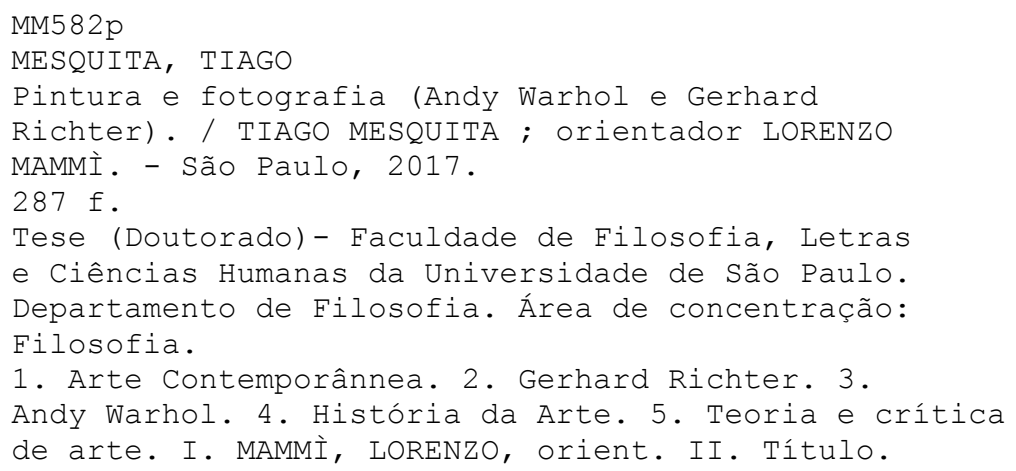




\section{Resumo:}

Na segunda metade do século XX, a relação entre pintura e fotografia se modifica.. Pintores como Andy Warhol e Gerhard Richter partem de imagens ordinárias e esquemáticas como modelo para as suas pinturas. Warhol assume os procedimentos gráficos e seriais dos meios de comunicação de massa, Richter representa com óleo sobre tela a superfície e a luz da imagem fotográfica. Essas novas práticas têm impactos decisivos na história da arte. Esta tese pretende levantar as relações entre pintura e fotografia na obra de Warhol e Richter. Tentaremos relacioná-los com um contexto mais amplo da arte do pós-guerra na Europa e nos Estados Unidos e entender como isso sugere uma mudança no sentido da arte depois da década de 1960.

\section{Abstract:}

From mid 20th century, the relations between painting and photography changes.

Painters like Andy Warhol and Gerhard Richter use ordinary and schematic images as a model for their paintings. Warhol assumes the graphic and serial procedures of the mass media, Richter represents with oil on canvas the surface and the light of the photographic image. These new practices have a decisive impacts on the history of art. This thesis aims to raise questions on the impact of the photography in the work of Warhol and Richter. We will try to relate them to a wider context of postwar art in Europe and the United States and to understand how this suggests a change in the direction of the visual arts after the 1960s. 
SUMÁRIO

$\begin{array}{ll}\text { Agradecimentos } & \text { p. } 06\end{array}$

$\begin{array}{ll}\text { Introdução } & \text { p. } 07\end{array}$

$\begin{array}{ll}\text { Capítulo } 1 & \text { p. } 18\end{array}$

$\begin{array}{ll}\text { Capítulo } 2 & \text { p. } 57\end{array}$

$\begin{array}{ll}\text { Capítulo } 3 & \text { p. } 118\end{array}$

$\begin{array}{ll}\text { Considerações finais } & \text { p. } 174\end{array}$

$\begin{array}{ll}\text { Bibliografia } & \text { p. } 182\end{array}$

$\begin{array}{ll}\text { Imagens } & \text { p. } 207\end{array}$ 
$\underline{\text { AVISO }}$

O trabalho vem acompanhado de um caderno de imagens. As obras mencionadas no texto são acompanhadas de números que servem como um índice dessas obras. 


\section{AGRADECIMENTOS}

Muitos dos questionamentos que tentei responder aqui surgiram durante as minhas atividades profissionais como professor de história da arte e crítico de arte. Por isso, sou muito grato aos alunos, amigos e colegas que escutaram o que eu tinha para dizer. Eu espero ter incorporado os questionamentos e as objeções do pessoal.

O meu orientador Lorenzo Mammì sempre foi generoso e paciente comigo. A tese não ficaria de pé sem ele. Guilherme Wisnik e Taísa Palhares, membros da banca de qualificação, junto com Lorenzo orientador, trocaram a biruta do aeroporto por uma bússola e ofereceram um caminho mais consistente para o trabalho. Os funcionários do departamento de Filosofia da Universidade de São Paulo conseguiram as melhores condições de trabalho. Agradeço Kerstin Küster, Dietmar Elger e todos do Gerhard Richter Archiv do Staatliche Kunstsammlungen, em Dresden.

Lauro Mesquita, meu irmão, também demonstrou interesse em ler tudo o que eu escrevo com entusiasmo, alegria e solidariedade. Ele me salvou muitas vezes e ajudou a salvar o texto. Agradeço ao trabalho da Lucimara Carvalho, que fez uma leitura muito atenta e generosa.

Amigos como Demétrio Toledo, Juliana Delamare, Joaquim Toledo Jr., Flávia Lima, Agustina Commas, Rafael Carvalho, Ana Prata, Alice Riff, Juliana Vettore, Cláudia Mesquita, Renata Lucas, Juliana Frontin, Bela Sister, Bruno Dunley, Rodrigo Andrade, Fábio Miguez, Sérgio Sister, Nara Rivitti, Lucas Arruda, Marina Rheingantz, Rodrigo Bivar, Lucia Koch, Suiá Ferlautto, Germana Monte-Mor, Paulo Monteiro, Paulo Pasta, Nuno Ramos, Mauro Restiffe, José Augusto Ribeiro, Agnaldo Farias, Fernanda Pitta, Patrícia Mourao, Alexandre Barbosa, Rita Vidal, Bárbara Rodrigues, Rafael Campos Rocha, João Bandeira, Thyago Nogueira, Andrés Sandoval, Marcos Gerez, Beatriz Matuck, Edmundo Clairefont, Marko Mello e Marcelo Bárbara, estiveram comigo esse tempo todo e me ensinaram muito mais do que imaginam. Rodrigo Naves, não bastasse todo o resto, convidou-me para lecionar em sua sala, onde pude desenvolver muitas das ideias da tese.

Além disso contei com a amizade e a solidariedade de Sergio Martins, Mario Cappi, Alexandre Casatti, Marcio José de Macedo, Maria Carolina Trevisan, Alexandre Britto Rocha, Nilza Micheletto, Camille Sproesser, Rodrigo Siqueira, Thaís Rivitti, Mateus Araujo, Maria Chiaretti, Christian Von Ameln, Ricardo Pereira, Nilza Micheletto, Felipe Narvaez, Mateus Potumati, Danilo Costabile, Maria Letícia Zioni Gomes, Frederico Meinberg, Vilma Eid, Heleno Augusto, Natalia Vieira, André Dulci, Cauê Alves, Murilo Brasileiro, Paula Oliveira, Munir Murad, José Guilherme Pereira Leite, Itaquê Santana Barbosa, Pedro Keppler, Marcela Vieira, Ciça Winter, Wagner Malta Tavares, Jordão Correa, Marina Weffort, Felipe Cohen, Leonardo Ferreira, Juliana Nolasco, Gustavo Vidigal, Fábio Maleronka, Rodrigo Moura, Thomas Rohrer, Bella, Juliano Soprani, Davi e Rafael Bernardo, Rogério Martins, Aline Valli, Isabel Diegues, André Calvente, Fabiano Scodeler, Marcos Nobre, Pedro Vieira, Maurício Takara, Guilherme Granado e Fernando Cappi .Minha família me manteve de pé e não sei como agradecer aos meus pais Marcos e Vânia, Carolina Monteiro, minha cunhada, e José. Mais do que qualquer um, devo muito à Juliana Carvalho, que com seu amor e a sua bondade deixam a vida boa. 
INTRODUÇÃO 
No começo dos anos 1960, a relação das artes de exposição com imagens reprodutíveis - como os impressos, a publicidade, as fotografias de álbuns e revistas, o cinema e, sobretudo, a televisão - é redefinida. As obras de Andy Warhol e de Gerhard Richter são centrais nessa discussão. Em perspectivas diferentes, eles redefinem esse debate. A partir do estudo da trajetória de um e de outro, se tentará entender algumas formas de aproximação entre pintura e fotografia no pós-guerra.

A relação da pintura com a fotografia - e com outros campos da produção de imagem - contudo, antecede essa produção em mais de um século. Assim que daguerreótipos e calótipos se popularizaram (19-20), Jean Auguste Dominique Ingres, ${ }^{1}$ então o artista mais importante da Academia, começou a utilizá-los. ${ }^{2}$ Isso provavelmente aconteceu entre os anos 1830 e 1840, logo depois das primeiras formas de registro fotográfico. As imagens eram vantajosas para a realização de encomendas como os retratos. Com a fotografia não seriam mais necessárias longas sessões de pose. Embora a imagem achatasse o campo e modificasse a luz natural, ela conseguia um grau satisfatório de precisão e até sugeria novas poses, diferente das já convencionais em pintura.

O uso de fotografias para pinturas de gênero, sobretudo depois do surgimento da fotografia reprodutível, torna-se difuso. ${ }^{3}$ Artistas acadêmicos como Jean-Léon Gerome utilizam a foto como rascunho, como ponto de partida. Entre outros artistas interessados em fotografias, Simon Scharf menciona Horace Vernet, Thomas Couture, Jean-François Milliet, Charles Daubigny, Eugene Delacroix e Gustave Courbet. ${ }^{4}$ Todos voltaram os olhos para esse tipo de imagem entre os 1830 e 1840 (1- 4).

\footnotetext{
${ }^{1}$ SCHARF, Aaron. Art and photography. Penguin Books, 1978 (reimpressão, $1^{\text {a }}$ edição de 1968). p. 48. ${ }^{2}$ Van Deren Coke relembra duas declarações do artista sobre as fotografias: "Esta é a exatidão que eu gostaria de atingir". Assumindo sua atração por fotografias Ingres disse: "Elas são admiráveis, mas isso não pode se admitir". Em COKE, Van Deren. The painter and the photograph. Albuquerque: The University of New Mexico Press, 1964.

${ }^{3}$ SCHARF, Aaron. Art and photography. Penguin Books, 1978 (reimpressão, $1^{\text {a }}$ edição de 1968). p. 36.

${ }^{4}$ Idem, p. 37.
} 
As mútuas influências entre fotografia e pintura - sobretudo o modo como as fotografias impactavam o trabalho de alguns pintores - eram discutidas desde 1853, quando é publicado um estudo pioneiro feito pelo crítico inglês Robert Hunt. ${ }^{5}$ No texto aparecem questões importantes da época: discute-se, entre outros pontos, a exatidão da pintura vis-à-vis com a fotografia; as capacidades descritivas de cada forma de produção visual; e também em que medida poderíamos pensar o estilo na fotografia. A posição do autor é pensar a fotografia como uma imagem sem estilo. ${ }^{6}$ Daí em diante, alguns autores celebraram a novidade como um novo código visual; outros a repudiaram. De qualquer modo, as novas técnicas provocaram a imaginação visual e tiveram impacto estético imediato.

Para além de seu sentido estético, a fotografia criou seu próprio campo. As novas técnicas se legitimaram como uma forma de registro que não precisava ser necessariamente artística. A imagem fotográfica, de pronto, foi associada ao desenvolvimento técnico e científico e tratada como uma invenção, destinada a ajudar no progresso da ciência. A fotografia, segundo Britt Salvensen, irá animar debates importantes na ótica, na química e na psicologia. ${ }^{7}$

A foto funda um campo próprio de atuação e produção visual. Por vezes, ele tangenciaria o campo das artes, outras vezes não. De qualquer modo, ela passa a se dedicar a formação de arquivos e a funcionar como um relatório de informações. Tal função faz com que os fotógrafos substituam, desde o século XIX, diversos outros profissionais que se dedicavam a técnicas tradicionais de desenho, gravura e pintura sem a ambição de produzir arte de exposição. Vários pintores mais modestos, dedicados à

\footnotetext{
${ }^{5}$ COKE, Van Deren. The painter and the photograph. Albuquerque: The University of New Mexico Press, 1964. p. 8.

${ }^{6}$ Como veremos no Capítulo 3, é essa concepção que animará a aproximação de Richter com a fotografia.

${ }^{7}$ SALVESEN, Britt. See The Light: Photography, Perception, Cognition. Nova York: Prestel, 2013. p. 48-50.
} 
produção de retratos, miniaturas, registro de curiosidades, são desempregados pelos fotógrafos, assim como os miniaturistas e os desenhistas naturalistas. ${ }^{8} \mathrm{Com}$ a popularização dos dispositivos automáticos, são eles que começam a substituir os profissionais.

Uma das primeiras vítimas da fotografia como ofício foram os gravadores que se dedicavam à reprodução de pinturas famosas. ${ }^{9}$ Esse ofício, que na época já possuía cerca de quatro séculos, aos poucos se tornou obsoleto. ${ }^{10}$ Em um curto artigo, o historiador Giulio Carlo Argan nos conta como os gravadores que copiavam foram importantes para a difusão e a interpretação de uma cultura europeia entre os séculos XVII e XVIII. ${ }^{11}$ Com o fim desse ofício, era previsível que existisse alguma indisposição estética de parte dos artistas de ofício com os fotógrafos. A fotografia se torna o meio dominante na reprodução dos trabalhos de arte.

Independente das pendengas corporativas, a fotografia será pensada por vários críticos e artistas como uma espécie de alter ego da arte moderna. Um meio que as belas-artes identificam como uma forma outra de se produzir imagem, que pode ser inspiradora de novas formas de atuação, mas frequentemente é tratada como o exemplo do que a arte de vanguarda não deveria ser.

\footnotetext{
${ }^{8}$ SCHARF, Aaron; Art and photography. Penguin Books, 1978 (reimpressão, $1^{\text {a }}$ edição de 1968). p. 49. ${ }^{9} \mathrm{O}$ crítico Jules Janin saudou a invenção do daguerreótipo. Segundo ele, a nova técnica serviria aos artistas que não possuíam tempo para fazer esboços das pinturas baseados em vistas. Janin atribui à nova técnica um papel que já foi das gravuras, da reinterpretação e popularização das obras dos grandes mestres. Para ele, a arte ganhava um alcance muito maior com as reproduções fotográficas. Idem, p. 26. ${ }^{10}$ SCHARF, Aaron. Art and photography. Penguin Books, 1978 (reimpressão, $1^{\mathrm{a}}$ edição de 1968). p. 34.

${ }^{11}$ ARGAN, Giulio Carlo: "O valor crítico da gravura de tradução". Em . Imagem e persuasão: ensaios sobre o barroco. Org. Bruno Contardi. Trad. Maurício Santana Dias. São Paulo: Companhia das Letras, 2004. p. 16-21.
} 
Em textos e entrevistas, artistas distintos, como Picasso, ${ }^{12}$ Matisse $^{13}$ e Giacometti, afirmam, em menor ou maior grau, essa separação de tais regiões da criação visual. A imagem fotográfica excluiria o estilo e a subjetividade artística. Para alguns, até mesmo a verdade, o próprio Matisse não se cansa de lembrar, citando Delacroix, que “exatidão não é verdade". ${ }^{14}$

Nessa concepção, a fotografia é associada a um registro naturalista da arte, oposto ao esforço da arte moderna de criar novas formas de representação que destoassem das formas convencionais. Inclusive, em seus primeiros anos, parte da "fotografia de arte" também se guiará por valores modernos de originalidade, espontaneidade e busca por imagens únicas (11-14). Essa produção buscava a semelhança com a pintura para ser arte.

Quando olhamos pinturas modernas, tão distantes no tempo, que partiram de fotografias, como Neige fondante à Fontainebleau (1879-1880), de Paul Cézanne (5-6), e La Combe III (1951), de Ellsworth Kelly (9-10), ${ }^{15}$ notamos que ambos partem do mesmo princípio e ambos procuram a construção de uma especificidade da forma que os afaste da imagem original. Os dois artistas apagam as informações que fazem daquele lugar um pedaço reconhecível do mundo ou que façam lembrar uma fotografia. As pinturas lidam com suas próprias arquiteturas formais e com uma espacialidade distinta das referências de que partiram. O princípio é de transformação, da criação de uma nova percepção sobre o visível que destoa da percepção comum. O sentido artístico dos

\footnotetext{
${ }^{12}$ DUBOIS, Philippe $O$ ato fotográfico e outros ensaios. Trad. Marina Appenzeller. Campinas: Papirus, 1993. p. 31

${ }^{13}$ MATISSE, Henri. “Comentários anotados por Tériade”. Em Trad. Denise Bottmann. São Paulo: Cosac Naify, 2007.

${ }^{14}$ MATISSE, Henri. "Entrevista a Jacques Guenne". Em Denise Bottmann. São Paulo: Cosac Naify, 2007. p. 82.

${ }^{15} \mathrm{O}$ caso de Kelly é específico, pois, nessas pinturas feitas na França, ele partia de suas próprias fotografias para construir uma composição abstrata, planar e geometrizada. . Escritos e reflexões sobre arte. . Escritos e reflexões sobre arte. Trad.
} 
trabalhos, incusive, é dado pela capacidade de o estilo do criador adicionar algum significado a mais do que os encontrados na informação fotográfica.

No início desta pesquisa, pretendia-se estudar a produção de alguns pintores contemporâneos que, dos anos 1980 para cá, trabalharam a partir de imagens fotográficas, impressos industriais, stills e cenas de cinema. A princípio, seria comparado o uso da pintura na obra de artistas como Luc Tuymans, Wilhelm Sasnal, Peter Doig e Neo Rauch. Esses artistas começaram a trabalhar em um período em que a arte contemporânea está plenamente consolidada. Além disso, onde os dispositivos de produção de imagem reprodutível são absolutamente generalizados e acessíveis à parte significativa das sociedades industrializadas. O sistema de produção e difusão da arte contemporânea é absolutamente integrado com os modos de comunicação de massa e a indústria cultural.

Tal como os pintores do século XIX, artistas como Doig e Tuymans têm uma atitude interpretativa diante dos temas fotográficos. Embora preservassem a aparência gráfica, esses trabalhos apontavam para outra direção. Tuymans, Doig e Sasnal atribuem significados literários, decorativos e formais aos motivos de que se apropriam.

Em certo sentido, as pinturas restituem certa distinção entre a arte e outros meios de produção de imagem. Isso não era feito da mesma maneira que nas vanguardas modernas, pois existia uma distância, mesmo que mínima, entre fotografia e pintura. Artistas como Peter Doig, por exemplo, mudam a saturação das cores, inserem formas fantásticas e uma espacialidade etérea nos temas. Parte da imagem da fotografia, mas adiciona efeitos a ela. Tal operação retórica pretende tornar a vista renovada, particular.

Luc Tuymans deve ser o mais importante dos listados anteriormente. Seu trabalho sintetiza as questões dos outros artistas. O pintor belga começa muito jovem, em um período em que o tipo de pintura que lhe interessava era tido como antiquado, 
passadista e obsoleto. Não por acaso, ele decide fazer quadros com a aparência de objetos antigos, que simulariam relíquias.

Como afirma Ulrich Loock: "Ele [Tuymans] nega, desde o começo, a legitimidade histórica da sua própria prática artística, chama o que faz de pintura de antiquário e, em suas próprias palavras, nutre a sensação de que seu trabalho nasce com 40 anos a mais, por isso ele cobre alguns deles com um craquelado cuidadosamente produzido". ${ }^{16}$ Por isso, o artista se identificará com a figura do falsário. Ele cita explicitamente o caso de Han Van Meegeren, e passa a pintar quadros que ele diz ser "autenticamente falsos".

Tal como as primeiras fotografias de Cindy Sherman, produzidas a partir dos cacoetes das imagens de divulgação de filmes, as pinturas de Luc Tuymans também seriam o que Rosalind Krauss chamou de "cópias sem original". ${ }^{17}$ Ele criaria a imagem como uma relíquia, que teria suas propriedades estéticas intrínsecas, mas encenaria um sentido histórico que não necessariamente lhe pertencia. Pensaria a tela quase como uma relíquia. Um objeto portador de uma memória falsificada. A pintura aqui é um objeto farsesco. O colorido de suas telas é apagado, como que envelhecido. Tuymans trabalha como se acrescentasse idade às obras.

$\mathrm{O}$ artista afirma ter começado a trabalhar em um período em que a televisão era o modo de produção de imagens hegemônico,. ${ }^{18}$ portanto, logo afastou de si a possibilidade de criar a partir de imagens originais. Sua ideia era elaborar algum tipo de

\footnotetext{
${ }^{16}$ LOOCK, Ulrich: "On layers of sign-relations, in th light of mechanically reproduced pictures from tem years of exhibitions". Em SPECTOR, Nancy. Luc Tuymans. Londres: Phaidon Press, 2003. p. 34.

${ }^{17}$ KRAUSS, Rosalind: “Cindy Sherman: Untitled (1993)". Em BURTON, Johana. (Org.) Cindy Sherman (October Files). Cambridge: MIT Press, 2006. p. 98.

${ }^{18}$ ALIAGA, Juan Vicente. "Conversation with Luc Tuymans", Em SPECTOR, Nancy. Luc Tuymans. Londres: Phaidon Press, 2003. p. 34.
} 
sentido visual ou literário para as imagens escolhidas e apropriadas. Para ele, era possível narrar a partir desse material.

Embora pertença a uma tradição de pintura centenária - a pintura flamenga Tuymans pensa os seus quadros não só como imagem, mas como objeto; da mesma maneira que aquilo que é pintado se distingue marcadamente de seu motivo. As obras vão ser pensadas como documentos de uma outra época. Nos quadros de Tuymans, superfície, formas, figuras e imagem importam muito, mas o pintor também pensa a tela como um objeto portador de uma memória farsesca, como uma antiguidade inventada. Séries como Heimat (1995) (145) e Mwana Kitoko (2000), para além de sua qualidade como pintura, são pensados como símbolos e relíquias da história.

Esse modo de criar a obra de arte só foi possível com a aproximação entre formas de produção de imagem que antes não pareciam pertencer ao mesmo campo. Tal aproximação da arte moderna com o mundo do entretenimento, dos produtos comerciais em série, das imagens de cinema, fotografia e televisão tem início na segunda metade do século XX. Naquela época, artistas diferentes parecem buscar uma aproximação entre a cultura de massa e as vanguardas.

Embora se pintasse a partir de foto desde o século XIX, na segunda metade do século XX artistas começam a pintar como foto, emulando os efeitos e cacoetes da máquina fotográfica.

Artistas como Andy Warhol, Gerhard Richter e Richard Hamilton pretendiam anular a ideia moderna de estilo, de originalidade e de especificidade da arte. Mesmo que pintada a mão, a imagem da pintura quer se parecer com um objeto reprodutível. Na tela, Richter e Warhol copiavam a composição, a cor, os defeitos gráficos e por vezes a textura 
de imagens criadas por aparelhos mecânicos ou eletrônicos. Os artistas procuram acentuar a semelhança entre a chamada arte elevada e as outras imagens do mundo.

Por conta da semelhança dessas obras com outras formas de imagem, voltei a questões que havia explorado na minha dissertação de mestrado, Através do espelho, ${ }^{19}$ defendida em 2009, neste mesmo Departamento de Filosofia. Naquele trabalho, pesquisei o movimento da obra de Warhol em direção a formas industriais de criação. A troca do modo de pintar artesanal por uma maneira mecânica de transferir a imagem para a tela (a serigrafia).

No entanto, no trabalho de mestrado não se investigou a relação que Warhol faria entre o meio de arte e um novo "regime de imagens", inaugurado pela comunicação de massa e pela sociedade de consumo. Mais, não se pensou o momento em que Andy Warhol passa a manipular esses meios de comunicação produzindo as suas próprias imagens, o seu próprio estrelato. A dissertação era sobre a passagem da pintura tradicional para os recursos gráficos. Na produção posterior, Warhol tornava ainda mais explícito o diálogo travado com os meios de comunicação de massa.

A perda de especificidade do objeto artístico, a tentativa de alguns artistas aproximarem "obras de museu" das imagens reprodutíveis se tornou mais interessante do que a tentativa de atribuir sentidos retóricos por meio de efeitos de pintura a imagens fotográficas refeitas na tela. A pesquisa se concentrou em operações como a de Andy Warhol, mas buscou como contraponto a obra de Gerhard Richter. ${ }^{20}$ Dois usos distintos

\footnotetext{
${ }^{19}$ MESQUITA, Tiago. Através do espelho: a constituição da pintura inicial de Andy Warhol (19561968). Dissertação de Mestrado apresentada ao Departamento de Filosofia da Faculdade de Filosofia, Letras e Ciências Humanas da Universidade de São Paulo (FFLCH-USP) São Paulo, 2009.

${ }^{20}$ A banca de qualificação, formada pelos professores Lorenzo Mammì, Taísa Palhares e Guilherme Wisnik, foi decisiva para que eu tomasse essa decisão. As suas sugestões indicaram que o caminho do trabalho era esse.
} 
das imagens reprodutíveis em dois contextos igualmente diferentes no capitalismo avançado do Atlântico Norte: Estados Unidos e Alemanha.

Com isso, pretende-se discutir algumas das especificidades da produção artística no pós-guerra e sua relação com uma sociedade totalmente transformada pelos dois conflitos mundiais, a internacionalização da indústria cultural e a hegemonia americana.

Para entender o novo sentido dessas obras, sobretudo a ausência de promessa redentora nelas, é preciso compará-las com formas de criação anteriores ou contemporâneas a elas. Tomar-se-á a relação entre fotografia e pintura como eixo para explicitar essa diferença, sobretudo entre a produção moderna e essa primeira produção contemporânea.

Arranhando a superfície, serão expostas algumas posições da pintura em relação à fotografia no século XIX e no século XX. Pretende-se apresentar como alguns artistas e intelectuais fizeram essa comparação e o que isso revela de uma especificidade da arte moderna. Esse conjunto de características transborda das técnicas tradicionais, como a pintura, a escultura e o desenho e chega a dizer respeito à fotografia para ser vista em museu e a outras linguagens mais recentes. Trata-se de um capítulo que tenta demonstrar como pintores que mimetizam as técnicas reprodutíveis em suas linguagens redefinem a ideia do que era específico na arte desde o século XVIII.

No estudo sobre Andy Warhol, tentaremos entender o sentido da diluição de sua obra em um amontoado de signos da cultura de massa. Sua pintura utiliza clichês gráficos e fotográficos apropriados da cultura de consumo, transforma-os em mancha gráfica e os desloca para a tela. 
Warhol fazia isso por meio da serigrafia. Por isso, como uma máquina, podia reproduzir em série, indefinidamente, a mesma imagem. $\mathrm{O}$ artista produzia em massa. Não por acaso, começa a trabalhar com meios reprodutíveis: cinema, fotografia e meios de comunicação de massa, como revistas e televisão. Warhol produz um diagnóstico, em parte resignado, em parte entusiasmado, da adesão inevitável às formas industriais de produção de imagem. Sua pintura é trabalhada como participante desse circuito.

Diferentemente, Richter não mergulha no consumo delirante. O que lhe interessa na fotografia não são os ícones, nem as figuras reconhecíveis dos famosos. Formado na Alemanha Oriental, sob a inflexível educação do realismo socialista, ele parece ter um interesse estrutural pela fotografia. No começo de sua carreira, chega a dizer que não faz pintura, mas fotografia por outros meios. ${ }^{21}$ Trata-se de um momento de negação da autoria e das especificidades do estilo na pintura. Ele equipara essa forma de produção de imagem, a fotografia, com outras convenções criativas, associadas à pintura tradicional e à arte de vanguarda. Parece buscar o que há, se é que há algo, por trás dessas camadas de significados.

Este trabalho pretende entender esses dois momentos importantes que participam de uma redefinição da arte do século XX. Na época em que tal produção começou, a relação das vanguardas com um novo sistema de imagens era explorada de outra forma. Tratava-se de pensar uma forma de produção visual em oposição a outra. Esses artistas parecem abrir caminho para outra compreensão do papel e do significado histórico da arte.

\footnotetext{
${ }^{21}$ ELGER, Dietmar; OBRIST, Hans Ulrich. Gerhard Richter. Text: Writings, Interviews and Letters. Londres: Thames And Hudson, 2009.
} 
CAPíTULO 1 


\section{Espaços discursivos}

Em meados do século XIX, na França, surgem as primeiras tecnologias fotográficas. Mais ou menos na mesma época, pintores, escultores e desenhistas propõem novas formas de representação que contestam o convencionalismo classicista das Academias de Arte. Embora existam relações entre a captura de uma imagem em uma superfície sensibilizada e as novas formas de representação plástica ${ }^{22}$, elas não podem ser descritas como parte do mesmo fenômeno. ${ }^{23}$

A contestação das formas clássicas de representação na pintura e na escultura europeias muitas vezes busca reforçar o caráter contemplativo da obra de arte. Desde 1880, a parte importante da pintura europeia moderna nos faz perceber um descompasso entre a representação e o seu referente.

A fotografia estabelece, em seus primórdios, uma nova relação com a representação. A imagem fotográfica tem especificidades que a tornam diferente de todas as outras. O trabalho de quem opera a máquina é lidar com os modos de captação da luz por meio desse aparelho. As figuras são capturadas pelas lentes. Assim, as escolhas são

\footnotetext{
${ }^{22}$ Jonathan Crary afirma não haver uma relação de causalidade da criação da fotografia e as ousadias estéticas do século XIX, segundo o autor: "Evidentemente, não proponho uma relação causal de qualquer tipo entre essas duas formas [a pintura e o estereoscópio]. (...) Em vez disso, sugiro que tanto o "realismo" do estereoscópio como os "experimentos" de certos pintores eram igualmente inseparáveis e uma transformação muito mais ampla do observador, que possibilitou o surgimento desse novo espaço opticamente construído. O estereoscópio e Cézanne têm muito mais em comum do que se supõe". Em CRARY, Jonathan: Técnicas do observador: visão e modernidade no século XIX. Rio de Janeiro, Contraponto, 2012 (p. 124).

${ }^{23}$ Quando discute o declínio do retrato pintado na França do século XIX, Meyer Schapiro relativiza o papel da fotografia: "O declínio da arte do retrato é um fenômeno complexo que não pode ser explicado pelo advento da fotografia. Muito tempo depois de a câmera tornar o retrato acessível a baixo custo a quase todas as pessoas, o retrato pintado permaneceu símbolo de riqueza e importância social do indivíduo, acompanhando a decoração doméstica onde era pendurado. Mas em Paris, por volta do fim do século XIX, e, na geração seguinte, em outros lugares tornara-se um objeto menos comum para a exibição pública no Salão anual. (...) Talvez as mudanças na vida pública e doméstica, menos submissas agora aos velhos modelos de autoridade, costumes e discurso, tenham feito que as imagens conspícuas dos ancestrais como defensores de linhagens familiares e os parâmetros de distinção social parecessem supérfluos". Em SCHAPIRO, Meyer. Impressionismo: reflexões e percepções. São Paulo: Cosac Naify, 2002. p. 171-2.
} 
muito diferentes das feitas pelo artista, que determina a proporção, a volumetria e o lugar de cada elemento em uma pintura, um desenho, uma escultura, um relevo.

Mesmo que o artista das técnicas tradicionais trabalhe observando o seu referente, ele recorre a convenções e técnicas para definir onde fica cada elemento e como ele será descrito. A foto recorre a linguagens, mas as escolhas são de enquadramento, luz, do que entra e do que não entra em quadro. São duas formas distintas de produção de imagem, que em sua origem atuavam em campos próprios e ganharam sentidos sociais igualmente diferentes.

Rosalind Krauss chama esses contextos distintos de significação de "espaços discursivos". ${ }^{24}$ Segundo ela, as belas-artes e a fotografia atuavam em "dois campos culturais distintos, [que] pressupõem expectativas diferentes por parte do espectador e veiculam dois tipos distintos de saber". 25

Mesmo assim, essas formas de produzir imagem conversaram, aprenderam muito uma com a outra, se repeliram mutuamente e, desde então, parecem se comparar. A imagem fotográfica e as belas-artes às vezes se pensam uma como o contraponto da outra; às vezes se pensam como complementares. O diálogo das diferentes técnicas ligadas às belas-artes com formas de produção visual destinadas a outros contextos não é novo. No século XV, época em que a pintura e a escultura ainda lutavam para conquistar o caráter de reflexão autônoma que ganharam posteriormente, esse dialogo já acontecia.

Em muitos estudos da iconologia, de autores como Aby Warburg, Edgar Wind e Erwin Panofsky, aprendemos como o vocabulário de representação de temas antigos foi recriado pelo Renascimento a partir de fontes tão diferentes como a literatura

\footnotetext{
${ }^{24}$ KRAUSS, Rosalind. "Os espaços discursivos da fotografia". Em Editorial Gustavo Gili, 2002. p. 41. . O fotográfico. Barcelona:

${ }^{25}$ Idem.
} 
e as esculturas da antiguidade, mas também a partir de folhetos astrológicos, representações populares, cenografia e outras formas de representação muito distantes dos contextos de criação dos diferentes ofícios artísticos da época.

$\mathrm{O}$ que aconteceu entre o século XIX e o século XX é que muitas vezes intelectuais e artistas se valeram da diferença que as artes de exposição tinham das outras formas de produção de imagem para reforçar o sentido estético de suas obras. Tal esforço de distinção servia para a arte reivindicar um grau maior de reflexividade intelectual. Por exemplo, o artístico se comparou ao fotográfico em raciocínios diversos: fosse para afirmar o que havia de específico na pintura, fosse para afirmar o que havia de artístico na foto. De qualquer modo, os códigos de leitura que atribuíam um sentido ou outro a diferentes formas de produção de imagem provinham das formas estéticas consolidadas entre os séculos XVIII e XIX. Sua interpretação veio das ideias debatidas em torno das primeiras exposições de arte. Portanto, eram códigos das belas-artes.

\section{Arte e fotografia}

A França em meados do século XIX era um lugar de debate público intenso. Formulavam-se as mais variadas teorias e havia opiniões divergentes sobre a fotografia. Questionava-se o efeito das fotografias na nova sensibilidade, se elas seriam capazes de substituir a arte e se elas seriam a forma mais confiável de registro da natureza.

Jean-François Milliet, pintor da escola de Barbizon, convivia com muitos fotógrafos e tinha uma ótima impressão da fotografia, mas a circunscrevia a um campo específico de atuação. Ele pensava esse tipo de imagem dentro do código das belasartes, ${ }^{26}$ por isso atribuía à fotografia o papel de "molde da natureza", ${ }^{27}$ que é útil, é

\footnotetext{
${ }^{26}$ Cf. SEKULA, Allan. "On the invetion of photographic meaning". Em GOLDBERG, Vicki. Photography in print. Nova York: Simon and Schuster, 1981.

27 SCHARF, Aaron. Art and photography. Penguin Books, 1978 (reimpressão, $1^{\text {a }}$ edição de 1968 ). p. 92.
} 
interessante, mas nunca se tornaria uma escultura. Segundo seus argumentos, a fotografia seria um bom ponto de partida, mas ninguém chegaria à arte tendo a imagem fotográfica como fim.

Milliet via limites na fotografia. A ele parecia uma maneira de produção de imagens que dispensa a necessidade de composição. ${ }^{28}$ Sua capacidade descritiva não seria construtiva. As relações entre os elementos que constituem a imagem seriam dadas de antemão, ao fotógrafo restaria pouco a fazer. Por isso, o artista entendia a fotografia como fonte de informação visual, talvez a melhor disponível, mas só isso. Aqui, a informação é pensada como algo inferior à reflexão, à idealização presente na arte. Derivando seu raciocínio, na fotografia parecia haver muito para olhar, para processar, mas pouco a ser contemplado.

O intelectual britânico John Ruskin vai na mesma direção. Segundo Daniela Kern, embora Ruskin tenha comemorado o surgimento do daguerreótipo, ${ }^{29}$ ele associava a técnica a uma apreensão especular do real. ${ }^{30} \mathrm{~A}$ técnica, para Ruskin, possui limites muito estritos no esforço de captura da "poesia da natureza". ${ }^{31}$ Daniela Kern faz a seguinte citação do britânico: “a fotografia é utilitária enquanto registro (...), mas nunca será arte devido a sua natureza mecânica". ${ }^{32}$ Ruskin argumenta que a imagem fotográfica possui

\footnotetext{
28 “Comentando a situação das paisagens no Salão de 1855, Edmond About achou que uma era idêntica à outra. Originalidade, ele sugeriu, foi sacrificada no altar da verdade fotográfica. Uma homogeneidade aborrecida de estilo prevaleceu." Idem, p. 94.

${ }^{29}$ Citação de Ruskin: "É quase como transportar o próprio palácio; cada pedaço de pedra e vitral está ali, e evidentemente não há erros sobre proporções. (...). É uma nobre invenção - digam o que quiserem dela (...). Estou bastante encantado com meus daguerreótipos". Em KERN, Daniela. "John Ruskin, arte e fotografia: aceitação e resistência". Em Anais do XXX Colóquio do Comitê Brasileiro de História da Arte, Rio de Janeiro, CBHA, 2010. p. 113.

${ }^{30}$ Idem, p. 112.

${ }^{31}$ SCHARF, Aaron: Art and photography. Penguin Books, 1978 (reimpressão, $1^{\text {a }}$ edição de 1968), p. 102.

${ }^{32}$ KERN, Daniela. "John Ruskin arte e fotografia: aceitação e resistência". Em Anais do XXX Colóquio do Comitê Brasileiro de História da Arte, Rio de Janeiro, CBHA, 2010. p. 112.
} 
"limitada fidelidade à natureza". ${ }^{33}$ Como se tratava de um momento de hegemonia das artes plásticas como modelo de criação visual, a foto é tida como ofício menor.

Alguns intelectuais que tentaram uma ontologia da fotografia, fizeram restrições muito mais severas à imagem fotográfica. Logo depois de seu surgimento, pergunta-se se a memória dos homens se modificaria, para pior, com o advento da fotografia. ${ }^{34}$

Uma das questões mais prementes dizia respeito a sua credibilidade. A imagem já não se apresentava como uma recriação artesanal de uma visão, mas surgia como um aparecimento. A foto seria um análogo do real, um objeto especular, sem estilo, sem o trabalho do artífice. Alguns acreditaram que esse caráter foi responsável por uma forma mais exata de produzir imagens, outros que essa exatidão da imagem a tornava menos verdadeira. Essas noções variaram muito. Por vezes, a verdade dizia respeito a uma autêntica obra de arte; por outras era o registro mais confiável; por outras, ainda, a imagem era capaz de mobilizar e comover.

De acordo com a narrativa de Phillipe Dubois, em $O$ ato fotográfico, a atribuição de fidelidade à imagem fotográfica - nos séculos XIX e XX - era usada tanto para celebrar quanto para atacar as novas técnicas. Todos se voltavam para sua assombrosa capacidade especular. Para muitos a fotografia era vista "como a imitação mais perfeita da realidade". ${ }^{35}$

\footnotetext{
${ }^{33}$ Idem, p. 114.

${ }^{34}$ Dentre os autores que conheço, quem explora melhor essa hipótese do esquecimento por meio da fotografia é um ensaísta do século XX, Siegfried Kracauer. KRACAUER, Siegfried. "A fotografia”. Em . Ornamento da massa. Trad. Carlos Eduardo Jordão Machado e Marlene Holzhausen). São Paulo: Cosac Naify, 2009.

${ }^{35}$ DUBOIS, Philippe. O ato fotográfico e outros ensaios. Trad. Marina Appenzeller. Campinas: Papirus, 1993. p. 27.
} 
Dubois nos conta que boa parte do pensamento do século XIX vai tomar a fotografia como um lugar onde o sujeito criador não tem vez. Por isso, seria um lugar da objetividade, da certeza, e não da arte. O debate é rico, já que durante os anos 1850, na França, diversos fotógrafos, por conta da discussão sobre o realismo, reclamam a si o estatuto de arte. ${ }^{36}$ Mesmo assim, tanto nos salões de Paris quanto nas exposições internacionais a produção da imagem fotográfica é exibida na seção de invenções.

É interessante que os fotógrafos, já com um campo de atuação marcado, quisessem participar dos domínios das belas-artes e serem aceitos como criadores de obras que o espectador pudesse contemplar em uma exposição. Diante desse dilema de captação do real, alguns fotógrafos tentam mostrar a capacidade compositiva da foto nos termos da pintura e da escultura. De acordo com as concepções do século XIX expostas anteriormente, os fotógrafos, lidos pelo conjunto de códigos das belas-artes, não construiriam nada, retirariam uma imagem do seu contexto original como se paralisassem um reflexo no espelho.

Philippe Dubois chamará essa interpretação da fotografia de "discurso da mimese fotográfica" ${ }^{37} \mathrm{O}$ espaço discursivo da fotografia estaria ligado umbilicalmente às ideias de registro, de documentação, de arquivo. A fotografia estaria impossibilitada de qualquer imaginação ou elaboração mais complexa. Por isso, para alguns intelectuais do século XIX, pensá-la como uma forma de "arte poética", seria desastroso. Sua objetividade e técnica seriam a expressão de certa burocratização da sociedade, dos hábitos e dos gostos. Charles Baudelaire, tão atento às invenções, defensor de um caráter

\footnotetext{
36 KERN, Daniela. "John Ruskin, arte e fotografia: aceitação e resistência". Em Anais do XXX Colóquio do Comitê Brasileiro de História da Arte, Rio de Janeiro, CBHA, 2010. p. 113.

${ }^{37}$ DUBOIS, Philippe. O ato fotográfico e outros ensaios. Trad. Marina Appenzeller. Campinas: Papirus, 1993. p. 33.
} 
autônomo da obra de arte - como posicionamento reflexivo - é quem expressou com maior talento a rejeição à fotografia como imitação precisa, mas insossa da realidade.

Em sua diatribe contra a fotografia, ${ }^{38}$ em 1859, por conta da primeira exposição de fotografias adjacente ao Salão de Belas-Artes, Baudelaire, pela mesma razão que ataca a técnica, explica seu uso e importância. Não se trata de um texto de absoluta recusa à fotografia, mas, como as declarações de Milliet e Ruskin, de delimitação de um território.

Nos trechos dedicados à nova tecnologia, ele vê a fotografia como uma invenção útil. O seu temor surge quando essa ferramenta salta do terreno da técnica para o reino imaginativo das artes. Para Baudelaire, a utilização da fotografia não possuiria a densidade intelectual de qualquer projeto estético de interesse. Não lhe parece que a fotografia possa ser poética, imaginativa ou um saber estético.

Mais que isso, Baudelaire teme que o gosto por fotografia rebaixe o debate estético que acontecia ao longo do século XIX. Em texto inflamado, ele diz que a foto é incapaz de criar por ser pouco imaginativa, por ser muito próxima do "natural". Em outras palavras:

$\mathrm{Na}$ França, o pintor natural, como o poeta natural, é quase um monstro. O gosto exclusivo pelo Verdadeiro (tão nobre quando limitado às suas verdadeiras aplicações) reprime e sufoca o amor pelo belo. Onde seria necessário ver tão somente o belo, nosso público busca apenas o Verdadeiro. Ele não é artista, artista por natureza; talvez filósofo, moralista, engenheiro, apreciador de historietas instrutivas, tudo o que

\footnotetext{
38 "O público moderno e a fotografia". Em BAUDELAIRE, Charles. "Salão de 1859", Charles Baudelaire: poesia eprosa. Rio de Janeiro: Nova Aguilar, 1995.
} 
se quiser, mas espontaneamente artista, jamais. Ele sente, ou melhor, ele julga sucessiva e analiticamente. Outros povos, mais favorecidos, sentem de imediato, simultânea e sinteticamente. ${ }^{39}$

A fotografia parece a Baudelaire um subproduto do mesmo gosto que dá origem ao naturalismo literário e pictórico. A ele não interessa nem uma coisa nem outra. O naturalismo se afiaria na exatidão como valor estético e na objetividade como verdade, Baudelaire suspeita de ambas as certezas. Por isso, o poeta critica inclusive a exatidão da foto. Baudelaire duvida dela. ${ }^{40}$ Não vê verdade na descrição daquele dispositivo. Ele vê como um triunfo da cópia, não da criação humana. Entende como um registro preciso, mas morto. Por isso, também vê risco no gosto pela exatidão fotográfica, por sua função especular, credita seu sucesso a sua incapacidade de recriar experiências.

Em um dado momento, elogia a fotografia por sua capacidade de documentar, de preservar informações e documentos. Inclusive a compara a nobres ofícios como a estenografia, o jornalismo e instrumentos como o bloco de notas. ${ }^{41}$ Assim, divorcia a fotografia de qualquer exercício criativo, ao menos de qualquer exercício que se relacione com o campo das artes de exposição. Para Baudelaire, um dos problemas da fotografia seria se filiar, de forma ainda mais rebaixada, ao que haveria de pior no gosto da época: certo positivismo naturalista.

Segundo a régua das belas-artes, a foto como criação poética seria um desastre, embora tivesse outros usos. Aaron Scharf diz que o raciocínio de Baudelaire vê na fotografia uma "influência malévola". ${ }^{42}$ Sua busca por precisão poderia colocar em

\footnotetext{
${ }^{39}$ Idem, p. 801.

${ }^{40}$ No texto, chama os que creem nas garantias de exatidão da foto de "insensatos". O público ávido por fotografia recebe nomes menos lisonjeiros: são "adoradores do sol" e "gaiatos". Em BAUDELAIRE, Charles. "Salão de 1859", Charles Baudelaire: poesia e prosa. Rio de Janeiro: Nova Aguilar, 1995. p. 801-2.

${ }^{41}$ Idem, p. 803.

${ }^{42}$ SCHARF, Aaron; Art and photography. Penguin Books, 1978 (reimpressão, $1^{\text {a }}$ edição de 1968). p. 144.
} 
risco a arte como domínio do "impalpável e do imaginário". ${ }^{43}$ A fotografia seria para ele um inventário de objetos, uma listagem sem idealização, que empilharia dados como uma espécie de relatório de má infinitude. Um lugar em que qualquer sentido a ser dado à composição como um todo, como um tableau, se tornaria impossível. O texto é uma reação à entrada, pela primeira vez, depois de vinte anos, da fotografia nos salões. Na época, era uma imagem que seduzia um gosto ávido por verossimilhança, mas fora da arena institucionalizada da arte.

Ao rejeitar a fotografia, na verdade, o poeta afirma seu gosto por um tipo de arte anticlássica, romântica, que pede um novo tipo de contemplação, uma busca por singularidade formal, por singularidade subjetiva do estilo e por certa especificidade do objeto artístico. Em sua concepção, as artes tendem a se distinguir do olhar imitativo, do que Baudelaire atribui ao olhar fotográfico. ${ }^{44} \mathrm{~A}$ arte seria dotada de uma especificidade que a foto não possuiria. A técnica seria o domínio de uma repetição fria, sem subjetividade. $^{45}$

Mas essa não seria a única reação à difusão da fotografia em salões artísticos. Para além dos argumentos corporativos e críticos, o pintor Paul Huet questiona o uso da fotografia como modelo para a pintura. Segundo Huet, a foto reduziria as possibilidades de composição e atuaria, como afirma também Baudelaire, como inimiga da invenção e

\footnotetext{
${ }^{43}$ Idem, p. 146.

${ }^{44}$ No século XX, quem levou o discurso da "mimese fotográfica" mais longe foi Roland Barthes, em seu primeiro esforço de pensar a fotografia, $\mathrm{m}$ um ensaio seminal sobre a mensagem fotográfica de 1961, anterior, portanto, a sua obra mais importante sobre o assunto, A câmara clara. No texto de 1961, Barthes afirma que a fotografia transmite "o real literal". Por isso cria a definição complicada da existência na imagem fotografada de uma "mensagem sem código". Embora fale que essa "mensagem sem código" seja transmitida por meio de símbolos que nos trazem uma série de significados culturais, vemos o que vemos, não o que o fotógrafo criou a partir da matéria informe. O discurso será sofisticado em obras posteriores, mas aqui, com muito rigor, o autor mantem algo do tal caráter especular da foto. Cf.

BARTHES, Roland. "A mensagem fotográfica". Em O óbvio e o obtuso. Trad. Isabel Paschoal. Lisboa: Edições 70, 2009. p. 13.

${ }^{45}$ Cf. SALVESEN, Britt. See The Light: Photography, Perception, Cognition. Nova York: Prestel, 2013. p. 32 .
} 
da imaginação, necessárias para qualquer obra de arte. ${ }^{46}$ Aqui, é a ausência de estilo, o caráter protocolar atribuído à foto que o incomoda. A fotografia não estaria à altura do complexo de códigos da arte.

Os intelectuais mencionados pensam a fotografia como um sucedâneo empobrecido, embrutecido da imitação visual. Leem as imagens a partir do código cultural das belas-artes. Lá a fotografia é o oposto da composição, da construção de sentido a partir da disposição de materiais e formas em uma determinada ordem. A fotografia é o oposto da composição, para o bem e para o mal. É um indicativo de objetos registrados, mas que não diria nada sobre esses objetos.

Nos anos 1880, parte dos pensadores das vanguardas se valerá do exemplo fotográfico para radicalizar suas novas propostas formais. A fotografia, interpretada como um análogo visual, sem estilo, sem composição, servirá por vezes como modelo, em outras vezes como contraponto à produção de pintura.

A foto ajudaria alguns artistas a encontrar novas formas de representação visual a partir dela ou contra ela. Tudo dependia da relação que os artistas estabeleciam entre a fotografia e a banalidade das convenções acadêmicas ou da interpretação anedótica do realismo. Essa busca por formas de representação que destoassem dos critérios convencionais de verossimilhança fazem da fotografia uma questão. Mas como os artistas e intelectuais anteriores, esses artistas pensavam o sentido da fotografia em relação a um código consolidado das artes plásticas.

Antes dos anos 1880, a fotografia foi motivo de entusiasmo dos artistas que se incomodavam com a disposição tradicional das figuras na pintura. Com a fotografia

\footnotetext{
${ }^{46}$ SCHARF, Aaron. Art and photography. Penguin Books, 1978 (reimpressão, $1^{\text {a }}$ edição de 1968). p.
} 147. 
são sugeridos novos cortes, novas poses que as linguagens mais convencionais não haviam previsto. Certas noções de movimento e uma luz artificial também vão interessar a pintores como Edouard Manet ${ }^{47}$ e Edgard Degas. ${ }^{48}$

Degas, inclusive, fotografa e pensa as fotografias como parte de seu raciocínio visual. ${ }^{49}$ Com o surgimento da fotografia instantânea, na década de 1870 , a fotografia passa a ser fonte para a apreensão do efêmero, do fugidio e de um olhar anônimo sobre a cidade que consegue capturar o trânsito veloz das pessoas na metrópole. Embora a fotografia não seja integralmente responsável pelo sentido da pintura de artistas como Degas, Manet, Caillebotte, ela ajuda na construção de pontos de vista alternativos aos modelos acadêmicos de composição. ${ }^{50}$

A celebração, no entanto, é acompanhada de uma advertência. Quando transposta para a tela, a fotografia usada como modelo deveria escapar do que o teórico simbolista Albert Aurier chamava de "o impessoal e banal das fotografias". 51 A imagem deve evitar a verossimilhança fotográfica e buscar as novas formas de significar o mundo. A imagem deveria, portanto, ser transformada, sintetizada, reinterpretada pelos meios artesanais da arte. Ela ganha sentido quando codificada por esses meios. Melhor, quando apresenta novas maneiras de olhar para o mundo, tal como fizeram artistas como Cézanne, Van Gogh, Seurat e Gauguin.

\footnotetext{
${ }^{47}$ Aaron Scharf faz uma aproximação convincente entre a pintura de Manet Execução do Imperador Maximiliano, de 1867, e a reportagem fotográfica. SCHARF, Aaron. Art and photography. Penguin Books, 1978 (reimpressão, $1^{\text {a }}$ edição de 1968). p. 66-75.

${ }^{48}$ KOSINSKI, Dorothy. "Vision and visionaires: the camera in the contexto of symbolist aesthetics". Em Art, 2000. p. 18. (Org.) The artist and the câmera. New Haven: Yale University Press / Dallas: Dallas Museum of

${ }^{49}$ Cf. SCHAPIRO, Meyer. Impressionismo: reflexões e percepções. São Paulo: Cosac Naify, 2002. p. 180.

${ }^{50}$ KOSINSKI, Dorothy. "Vision and visionaires: the camera in the contexto of symbolist aesthetics". Em (Org.) The artist and the câmera. New Haven: Yale University Press / Dallas: Dallas Museum of Art, 2000. p. 14.

${ }^{51}$ Idem, p. 16.
} 
O crítico Félix Fénéon traduz melhor essa necessidade de modificar uma imagem a que se atribui transparência valendo-se de um tratamento formal mais radical:

[quantos] milhares de detalhes insignificantes o olho percebe? Alguém deve selecionar o essencial, trata-lo e reproduzi-lo - ou, melhor, produzi-lo. (...) Desprezando a fotografia, o pintor se propõe a reter, com o menor número possível de linhas e cores características, a realidade íntima, a essência do objeto que ele seleciona. ${ }^{52}$

O raciocínio enfatiza a escolha e um caráter ideal da arte que a diferenciaria de uma mera imitação do olhar. Fénéon iguala a fotografia ao gosto naturalista que ele considera vulgar. Ele identifica nessa nova tecnologia uma imagem do passado, que assume as tarefas menos reflexivas da arte e as banaliza. O seu interesse é em artistas que proporiam novas maneiras de perceber o mundo. Por isso, aposta nas novas sínteses de cor de artistas como os neoimpressionistas Georges Seurat e Paul Signac.

A imagem fotográfica é lida como mais do mesmo. Fénéon, portanto, faz coincidir uma crítica das convenções tradicionais da arte com uma crítica da fotografia. Inclui essa imagem fotográfica não como um sistema próprio de imagens, mas como um barateamento de um tipo de pintura que, a seus olhos, se tornara obsoleto. Aliás, mais do que isso, com a fotografia a pintura deveria radicalizar os seus recursos interpretativos na forma. Fénéon abre o campo para uma interpretação comum da relação entre fotografia e arte no século XX. A interpretação que atribui o surgimento da arte moderna ao novo papel desempenhado pela foto.

\footnotetext{
${ }^{52}$ Félix Féneon sobre o salão de 1889. Citado em SCHARF, Aaron. Art and photography. Penguin Books, 1978 (reimpressão, $1^{\text {a }}$ edição de 1968). p. 250.
} 
Foi comum associar a fotografia a um novo episódio da história da arte. Essa narrativa opera por uma lógica de substituição tecnológica. ${ }^{53}$ As técnicas antigas são substituídas por novidades que assumem, no ritmo do avanço técnico, algumas de suas atribuições tradicionais. Nesse raciocínio, com maior ou menor sofisticação, diz-se que ao desobrigar a arte de algumas demandas, a foto liberava a pintura, por exemplo, de inventar outras coisas, de ousar e de experimentar.

A pintura chegava às experimentações do século XIX por estar desobrigada a fazer o que a fotografia passaria a fazer. Nesse tipo de associação, pensa-se que a fotografia e a arte atuavam no mesmo campo ou, de acordo com Rosalind Krauss, no mesmo "espaço discursivo". ${ }^{54}$ Em narrativas sobre as origens míticas da arte moderna é comum afirmar que as técnicas artísticas manuais não precisavam mais se ocupar da descrição do imediatamente visível. A pintura, a escultura, o desenho e a gravura estavam livres desse esforço. Como se um encargo fosse deixado de lado e, agora, ele coubesse à fotografia.

Por conta disso, duas noções são definidas. A fotografia se ocupa de uma representação mais acurada da verossimilhança e da capacidade de produzir ilusão e de nos trazer à mente elementos que estão ausentes. Mas a arte reencontra nesse raciocínio sua vocação moderna e se vê livre de impedimentos outros. Ela agora lida com sua própria matéria e reinventa mesmo o espaço de representação. A arte diante de uma técnica objetiva agora poderia ser arte de verdade.

\footnotetext{
${ }^{53}$ Criticada na nota 1, pelo trecho de Meyer Schapiro. Em SCHAPIRO, Meyer: Impressionismo: reflexões e percepções. São Paulo: Cosac Naify, 2002. p. 171- 2.

${ }^{54}$ KRAUSS, Rosalind. "Os espaços discursivos da fotografia”. Em Gustavo Gili, 2002. O fotográfico. Barcelona:
} 
No texto "Ontologia da imagem fotográfica", 55 escrito em 1945, depois da Segunda Guerra Mundial e já em um período triunfante das vanguardas, André Bazin expõe um raciocínio sobre o papel da fotografia no surgimento da arte moderna muito semelhante ao argumento das primeiras vanguardas do século XIX. O artigo é muito interessante, importante e tem como vetor um esforço de legitimação do cinema como linguagem artística autônoma. Para isso, o autor coloca o surgimento da foto como estopim de uma visão mais moderna da arte.

Para Bazin, a fotografia é portadora de uma “objetividade essencial”. Por isso, se ocuparia de nobres tarefas realistas, como as que ele chama, de maneira vaga, de "revelações do real". Tal esforço seria feito de modo impessoal, pela captura de algum detalhe ou algum gesto que nos fizessem entender melhor o espaço fotografado. ${ }^{56}$ Nesse aspecto, Bazin é mais sofisticado que os outros autores do raciocínio mimético aqui expostos anteriormente. A fotografia é capaz de produzir sugestões visuais instantâneas e inusitadas. Por mais que Bazin reforce o papel de certo olhar fotográfico, ele mantém e sintetiza parte de um argumento que pensa o começo da arte moderna como uma resposta à verossimilhança fotográfica. Bazin, bastante hiperbólico, conclui:

A fotografia vem a ser, pois, o acontecimento mais importante da história das artes plásticas. Ao mesmo tempo sua libertação e manifestação plena, a fotografia permitiu à pintura ocidental desembaraçar-se definitivamente da obsessão realista e reencontrar a sua autonomia estética. ${ }^{57}$

\footnotetext{
${ }^{55}$ BAZIN, André: "Ontologia da imagem fotográfica". Em O que é o cinema. Trad. Hugo Mader. São Paulo: Cosac Naify, 2014.

${ }^{56}$ Idem, p. 33.

${ }^{57}$ Idem, p. 34.
} 
Parafraseando Rosalind Krauss, essas leituras incluem a fotografia como um episódio da história da arte. Ela atenderia aos sentidos da arte feita para ser vista em exposição e responderia aos gêneros das belas-artes e suas especificidades estilísticas. Rosalind Krauss discorda desse ponto de vista. Comentando críticos e curadores contemporâneos, ela objeta:

Quando decidiram que o lugar da fotografia do século XIX era dentro dos museus, que a ela era possível aplicar os gêneros do discurso estético e que o modelo da história da arte muito bem lhe convinha, os especialistas contemporâneos foram longe demais. (...) eles determinaram que era possível aplicar outros conceitos do discurso estético ao arquivo visual. ${ }^{58}$

Rosalind Krauss identifica como problema metodológico fundamental dos críticos de fotografia a submissão da lógica da foto ao espaço discursivo das artes. Tal discurso se basearia no sentido expositivo da imagem, que se tornaria lugar de contemplação, pendurada em uma parede. Segundo a autora, o trabalho desses fotógrafos era feito em outra lógica. Sua imagem não era pensada como única, mas trabalhada como parte de um arquivo, ${ }^{59}$ parte de um catálogo ${ }^{60}$ Krauss percebe uma lógica específica do fotográfico, que demandaria outra forma de percepção do público, outra relação com a autoria e com a ideia de obra.

Na verdade, os códigos das belas-artes serão, por muitos anos, hegemônicos para se determinar tanto a especificidade da obra de arte como o seu valor de exposição. A fotografia que se pretende artística, no fim do século XIX e começo do século XX opera

\footnotetext{
${ }^{58}$ KRAUSS, Rosalind. "Os espaços discursivos da fotografia”. Em . O fotográfico. Barcelona: Gustavo Gilii, 2002. p. 49.

${ }^{59}$ Idem, p. 48.

${ }^{60}$ Idem, p. 55.
} 
dentro desses códigos. Por isso, boa parte das interpretações que lemos acima usa a foto como contraposição não a toda a arte, mas ao que a arte deveria ser: um espaço idealizado de contemplação, que se diferencia do mundo. A arte até pelo menos o meio do século XX é um espaço que pretende fornecer alguma dissonância em relação ao mundo visível. Mais que isso, às formas convencionais de organizá-lo visualmente.

Mesmo as interpretações mais amigáveis da fotografia parecem não estar falando de sua especificidade, mas de como essa forma de produção de imagem se relaciona com uma longa linhagem de obras visuais produzidas de acordo com os códigos da história da arte - disciplina que se consolida entre os séculos XVIII e XIX. ${ }^{61}$

A maioria desses textos tenta determinar um campo para a fotografia a partir dos códigos da arte. Mesmo um trabalho mais recente, como o artigo de André Bazin, diz que, por conta da fotografia, a arte precisou encontrar outros critérios de afirmação de sua especificidade. A arte se afirmaria porque a foto ocuparia um pedaço do seu campo como parte de sua história. ${ }^{62}$ A delimitação do papel dos diferentes campos de atuação visual, nesse momento, parece ser controlada pelas artes de exposição, as artes plásticas.

\section{Arte na era moderna}

Os códigos de leitura que afirmavam o artístico nos textos mencionados são baseados em uma concepção de arte que ganha corpo com a consolidação europeia de um sistema das artes centralizado nas academias. Tal forma de pensar dá continuidade aos esforços renascentistas de fazer reconhecer a arte como uma tradição intelectual respeitável. Podemos adotar como marco inicial dessa nova forma de organizar o meio

\footnotetext{
61 “A ideia de uma história universal da arte afirmou-se, fora dos círculos estreitos dos artistas, somente no século XIX, na medida em que a matéria da qual ela cada vez mais se apropriava descendia de todos os séculos e milênios precedentes". BELTING, Hans. O fim da história da arte: uma revisão dez anos depois. São Paulo: Cosac Naify, 2006. p. 25.

62 Bazin afirma categoricamente que a fotografia é um momento central da história da arte. BAZIN, André. "Ontologia da imagem fotográfica". Em Paulo: Cosac Naify, 2014. O que é o cinema. Trad. Hugo Mader. São
} 
de arte europeu a fundação da Academia de Paris em 1648. Diferente das academias italianas que existiam anteriormente, o modelo francês possui currículo rígido e horário para as aulas. É uma instituição que pretende organizar não só o ensino, mas toda a cadeia produtiva.

Por meio dela seriam determinados novos critérios de prestígio artístico e novas categorias de avaliação das obras. Em torno da academia, são promovidas conferências, premiações e exposições. O empreendimento está ligado à ascensão do poder real. ${ }^{63}$ A Academia se torna o lugar de produção, difusão e discussão das artes. Rapidamente, um modelo mais ou menos parecido com o francês se espalha por toda a Europa.

A Academia reorganiza a carreira dos artistas. Centralizada, retira poder das oficinas espalhadas pela cidade e passa a avaliar os artistas por meio de novas estruturas públicas. O prestígio e o reconhecimento dos trabalhos agora têm lugar em exposições e premiações organizadas pela instituição. As exposições tornam-se regulares em $1737 ;^{64}$ suas premiações e as escolhas da Academia transformam-se em assunto público cerca de dez anos depois. A partir daí as escolhas do júri de premiação, do júri de seleção e o gosto do público se tornam temas de debate público.

No começo do século XVIII, o reinado, sob a regência de Felipe II, volta a governar a partir de Paris. O círculo de literatos, artistas e pensadores que se dedicava a pensar o gosto se desloca da aristocracia para círculos maiores que os previamente

\footnotetext{
${ }^{63}$ Cf. PEVSNER, Nikolaus. Academias de arte. Trad. Vera Maria Pereira). São Paulo: Companhia das Letras, 2005. p. 143.

${ }^{64}$ HABERMAS, Jürgen. Mudança estrutural na esfera pública: investigações quanto a uma categoria da sociedade burguesa. Trad. Flávio Kothe. Rio de Janeiro: Tempo Brasileiro, 1984. p. 56.
} 
existentes. Isso modifica a relação dos intelectuais e artistas com a mera relação de mecenato. $^{65}$

Pouco a pouco, mais gente passa a prestar atenção no que era feito na Academia e a discutir essa produção. Burguês, menos interessado em um gosto galante do que em um debate de ideias, esse público moderno ${ }^{66}$ faz com que a arte se libere "de funções de representação social" e se "torne objeto da livre escolha e de tendências oscilantes. O "gosto", pelo qual, a partir de então se orienta, expressa-se no julgamento de leigos sem competência especial, pois no público qualquer um pode reivindicar competência. ${ }^{67}$

O debate passa a se dar em bases menos utilitárias e não está necessariamente ligado ao gosto da corte. O público é crescente em meados do século XVIII e passa a ser disputado. A Academia, inclusive, com esse público alargado tenta chamar a si um papel pedagógico. Seria responsável pela orientação e pela formação de valores cívicos e morais dessa audiência. $\mathrm{O}$ debate entre críticos, artistas e historiadores acontece não apenas na disputa pelo "julgamento dos leigos", ${ }^{68}$ mas também pelo mercado de arte. Essa instituição se fortalece. É agora uma das formas de financiamento de todas as artes. ${ }^{69} \mathrm{O}$ que modifica a relação do público com as obras.

\footnotetext{
65 “(...) a nobreza e a grande burguesia dos banqueiros e dos burocratas que assimilava a ela se encontravam com a 'intelectualidade' como que em pé de igualdade. Nos salões das damas do mundo, da aristocracia e da burguesia circulam filhos de príncipes e de condes, bem como de relojoeiros e merceeiros. Nos salões, o espírito não é mais um serviço prestado ao mecenas; a 'opinião' se emancipa dos liames da dependência econômica". Idem, p. 49.

${ }^{66} \mathrm{~A}$ medida em que as exposições públicas atraem circuitos mais amplos, pondo as obras de arte em contato imediato com o público mais amplo e passando por cima da cabeça dos entendidos, estes não podem mais manter a sua posição, pois a função deles já se tornou dispensável: agora ela é assumida pela crítica profissional" Em idem, p. 57.

${ }^{67}$ Idem, p. 56.

${ }^{68}$ Idem.

${ }^{69}$ PEVSNER, Nikolaus. Academias de arte. Trad. Vera Maria Pereira. São Paulo: Companhia das Letras, 2005. p. 205.
} 
De acordo com Michael Fried, por volta de 1747, a reação acadêmica ao rococó traz de volta debates que no século anterior haviam definido o gosto da nobreza e o ensino das artes. Assuntos como a hierarquia dos gêneros e mesmo o papel público da arte produzida ${ }^{70}$ passam a ser rediscutidos, agora a partir do "interesse público" das artes. Em nome da clareza de princípios e de um papel mais mental da arte, recuperam-se valores estéticos clássicos contra o caráter decorativo, luxurioso e pitoresco do rococó de corte francês.

As obras debatidas por artistas e intelectuais não deveriam se concentrar em sentidos decorativos como, por exemplo, na pintura de François Boucher. A pintura, a escultura, o desenho, sobretudo o desenho, ${ }^{71}$ eram lugar de se articular raciocínios visuais que orquestrassem uma relação de elementos complexos. A relação da figura com o espaço, com a luz, a articulação de olhares dos personagens da pintura e o sentido de cada elemento disposto sobre a superfície. A pintura deve resolver sua unidade pictórica $^{72}$ a partir de suas relações internas, sem prestar atenção no efeito que ela teria no lugar em que fosse colocada. São esses arranjos compositivos que dariam sentido ao trabalho. $\mathrm{O}$ modo como cada elemento se relacionaria dentro dos limites da tela. O sentido se desprenderia tanto do espaço de instalação, como da função social da pintura. Por isso, Fried, para explicar o período, retoma o conceito setecentista de "ficção suprema". ${ }^{73}$

\footnotetext{
${ }^{70}$ Cf. FRIED, Michael. Absorption and theatricality. Chicago: University of Chicago Press, $1988\left(1^{\text {a }}\right.$ edição de 1980).p. 35.

71 "O desenho deve ter primazia sobre a cor no espírito do artista. De acordo com Winckelmann, o desenho deve ocupar o primeiro, o segundo e o terceiro lugar numa obra de arte. (...) Por esse motivo os promotores do novo movimento [neoclássico] não davam muito valor ao brilho da pintura a óleo. (...) E diz-se que Schiller chegou a referir-se aos quadros do Museu Dresden nos seguintes termos: 'Tudo estaria bem se os desenhos não estivessem preenchidos pela cor'. Em PEVSNER, Nikolaus. Academias de arte. Trad. Vera Maria Pereira. São Paulo: Companhia das Letras, 2005. p. 197.

${ }^{72}$ FRIED, Michael. Absorption and theatricality. Chicago: University of Chicago Press, 1988 ( $1^{\text {a }}$ edição de 1980). p. 76.

${ }^{73} \mathrm{O}$ conceito diderotiano de tableau cumpre papel fundamental nessa definição, Cf. Idem, p. 96.
} 
Ao interpretar os textos de Denis Diderot, o crítico diz que naquele momento “a pintura como um todo também deveria ser tal sistema de causas e efeitos dramáticos e expressivos". ${ }^{74}$ Fried a partir do seu conceito de absorção, ${ }^{75}$ tipifica um trabalho que se isola completamente do espaço em que está instalado, como se ignorasse a presença do espectador, para que a cena se desenrole como um ilusionismo perfeito, uma obra à parte dos acontecimentos da vida $(15-17)$. O importante é que as obras abandonam o seu sentido decorativo habitual e perdem sua relação íntima com o espaço onde seriam instaladas, ${ }^{76} \mathrm{O}$ seu sentido é determinado pela unidade da obra em si mesma, por suas relações internas. Por isso, deve ser avaliado pelo tema, pela disposição das figuras no espaço e pela capacidade de convencer o público, que agora se posta diante da tela como contempla o teatro e a música, como em um espetáculo público. ${ }^{77}$

A obra passa a se relacionar com esse público e a produção crítica também. Os trabalhos são endereçados a esse novo tipo de espectador. São obras que dialogam com a produção dos críticos e dos outros artistas. Nikolaus Pevsner mostra o quanto esse debate intelectual do que a arte deveria fazer em relação ao público foi importante para a difusão do neoclassicismo em toda a Europa. Pevsner, entende esse interesse renovado pelo classicismo expresso em um debate de ideias que aconteceria a partir de $1745 .{ }^{78}$ Uma

\footnotetext{
${ }^{74}$ Idem, p. 86.

${ }^{75}$ A absorção seria uma forma em que a arte se comportaria de maneira autocontida e autossuficiente. Ela não inclui o espectador no seu campo de visão, mas se endereça a ele. O exemplo mais bem-acabado desse tipo de pintura, no seu nascedouro, é o trabalho de Jean-Baptiste-Siméon Chardin. O interessante é que as pinturas tidas por Fried como "teatrais" também se endereçam ao espectador. O historiador tipifica dois grupos de obras do século XVIII com base no modo de a obra se endereçar ao espectador ${ }^{76}$ MAMMÌ, Lorenzo. “As bordas”. Em O que resta: arte e crítica de arte. São Paulo: Companhia das Letras, 2012. p. 60.

77 "Eu creio que jaz no coração da concepção antirrococó de pintura uma relação entre pintura e espectador. Para Diderot e seus colegas, a tarefa do pintor era, sobretudo, alcançar a alma do espectador por meio dos seus olhos." FRIED, Michael. Absorption and theatricality. Chicago: University of Chicago

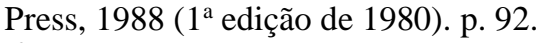

78 PEVSNER, Nikolaus. Academias de arte. Trad. Vera Maria Pereira. São Paulo: Companhia das Letras, 2005. p. 194.
} 
série de livros sobre a produção visual da antiguidade começa a ser publicado a partir daí. $^{79}$

Sob a influência do historiador da arte Johann Joachim Winckelmann, boa parte do pensamento acadêmico reage ao rococó, antes dominante, em nome de uma produção clara, feita de narrativas exemplares, convincentes, baseadas no desenho. ${ }^{80} \mathrm{~A}$ obra é pensada como o tableau, uma imagem idealizada à parte que articula ideias em um espaço delimitado sem se relacionar com o espectador ou com o espaço ao seu redor. ${ }^{81}$

Falando sobre os salões franceses do século XIX, que se ampliam muito e se tornam um espetáculo de massa, radicalizando o que acontecia no século anterior, Lorenzo Mammì precisa esse novo tipo de especificidade que a arte reclama para si. Em um trecho, o crítico de arte define como se dá essa mudança na relação com o espaço:

A obra de arte se torna independente de sua colocação no espaço renunciando inclusive às mediações rituais que o Renascimento estabelecera - porque o espaço já lhe foi subtraído. Extraída de seu lugar físico em prol de uma categorização abstrata - baseada em critérios não valorativos como o gênero ou as dimensões -, reage contra essa classificação transferindo para o seu interior a ordem que deveria situa-la em um contexto. A obra passa a valer por sua ordenação interna contra o contexto em que é colocada. A ausência de lugar próprio, que permitia estocagem, se torna então ponto de partida para uma

\footnotetext{
79 "Embora seja fácil identificar em qual estilo ou filosofia os ataques desses artistas e pensadores miravam, é impossível definir em poucas palavras o conteúdo exato do novo movimento”. Idem, p. 195. ${ }^{80}$ PEVSNER, Nikolaus. Academias de arte. Trad. Vera Maria Pereira. São Paulo: Companhia das Letras, 2005. p. 196.

${ }^{81}$ FRIED, Michael. Absorption and theatricality. Chicago: University of Chicago Press, 1988 ( $1^{\text {a }}$ edição de 1980). p. 95-105.
} 
autonomia radical, que reage justamente a toda classificação e acumulação. ${ }^{82}$

Depois da década de 1880, a arte moderna não só continua a experiência da imagem autocontida em seus limites como a amplia. Alguns artistas adotam outros critérios de verossimilhança. A imagem não é mais ou menos verdadeira por se aparentar mais com o mundo visível. A pintura, como um objeto que se resolve a si mesmo em boa parte da arte moderna, lança um juízo crítico sobre as maneiras de descrever e pretende fornecer um jogo sensorial e intelectual mais elevado do que as percepções mais ordinárias.

Segundo Lorenzo Mammì, "as condições perceptivas" da arte a partir do impressionismo têm necessidade de isolamento, o que muda inclusive a maneira de se exibirem os trabalhos e apreciá-los. ${ }^{83}$ Os trabalhos pedem um intervalo maior entre uma obra e outra, molduras mais discretas, um espaço expositivo supostamente mais neutro e condições de contemplação mais concentradas. ${ }^{84}$ Eles mostram a sua distância e sua diferença da apreensão mais imediata do mundo o tempo todo. A arte moderna reconstrói a representação a partir de outros princípios que nos fariam, inclusive, problematizar a nossa percepção com seu contraponto às formas de apreensão dadas pela cultura. ${ }^{85}$

\footnotetext{
${ }^{82}$ MAMMİ, Lorenzo. "As bordas". Em O que resta: arte e crítica de arte. São Paulo: Companhia das Letras, 2012. p. 60.

${ }^{83}$ MAMMİ, Lorenzo. "As bordas". Em Companhia das Letras, 2012. p. 68-73.

${ }^{84}$ Aqui também me apoio no ensaio de Lorenzo Mammì, "Agora a coerência só se dá no quadro, e se dá apenas porque é um quadro. A superficialidade da impressão, o plano bidimensional da tela, o enquadramento que se apresenta explicitamente como recorte são condições dessa conciliação impossível de outra maneira, ao mesmo tempo que confessam sua precariedade. A perspectiva e a modelagem pelo claro-escuro se tornam, antes de tudo, hipócritas. A moldura é inútil porque já não há um mundo externo a ser mantido a distância, apenas um fluxo descontínuo de experiências. Apenas o quadro é um mundo. É necessário, então, inventar mediações que afastem o caos para mais longe, ou o suguem para dentro da obra, onde poderá ganhar sentido". Idem, p. 73.

${ }^{85}$ Aqui vale lembrar a máxima modernista do cineasta Jean-Luc Godard: "Cultura é regra, arte é exceção".
} 
A produção acadêmica e o próprio salão haviam perdido o prestígio, suas formas de representação também se vulgarizaram. Desde meados do século XIX, a pintura acadêmica que emulava o gosto neoclássico do século anterior imitava Ingres, tornara-se um arremedo de convenções legíveis. Ela era ainda bastante apreciada por um gosto burguês nostálgico, que identificava naquelas convenções a única forma de arte possível. Na mesma época, essas convenções apareciam nos impressos, nas embalagens, na cenografia, nos elementos de uma cultura industrial do espetáculo nascente, que embora moderna, emulava uma figura pálida da tradição.

Era contra essa tradição que a arte moderna, pelo menos até a Segunda Guerra Mundial, se insurgiu. A rejeição às formas consolidadas de representação, baseadas na perspectiva linear, é também a rejeição a um passado que não parecia guardar relação com a experiência urbana da época e parecia se afundar em clichês.

Os artistas europeus do fim do século XIX e começo do século XX pesquisam novas formas de representação para escapar desse vocabulário de cacoetes. Embora se insurjam contra o passado e contra as formas tradicionais, fazem isso para preservar a arte. Para preservar e intensificar a experiência privada e contemplativa de observação desinteressada ${ }^{86}$ Esses artistas, mesmo quando matam a arte, o fazem para preservar a possibilidade de que a sua experiência reflexiva e intelectual permaneça. $O$ antiilusionismo da pintura moderna é um esforço nesse sentido.

T.J. Clark, em sua análise da obra de Picasso, enumera qualidades de diversos artistas, como Schwitters, Matisse, Brancusi, Tatlin, Mondrian, Bonnard, Maliévitch,

\footnotetext{
86 "O modernismo no sentido convencional do termo, começa com a marginalização forçada da vocação artística. (...) A vanguarda deixou para trás as preocupações mais antigas da arte pública oficial, não por qualquer rebelião especial por parte dos seus membros, mas porque seus representantes políticos haviam descartado as instituições e ideais pelos quais a arte oficial metaforicamente representava. " Em CROW, Thomas. Modern art and the common culture. New Haven: Yale University Press. p. 17.
} 
Duchamp, Pollock e também Picasso, para encontrar uma nota melancólica em comum entre todos eles. Para o autor, essa melancolia reforçava essa reflexividade radical da melhor arte do século passado, que por meio do estilo, processa um mundo horrendo ${ }^{87}$ que ela prefere evitar. A arte recua ao mundo privado, à reflexão solitária para tomar distância de um século de catástrofes, como as duas guerras mundiais, o holocausto, a miséria, a bomba atômica e a decadência da sociedade burguesa.

Clark se pergunta se "a arte moderna não seria então uma longa recusa, uma longa forma de evitar as catástrofes, um conjunto de encantos contra um presente intolerável?"” ${ }^{88}$ A pergunta é retórica. O autor pensa assim afirmativamente. O que nos interessa aqui é como, a partir de uma relação com a história social, o autor encontra na obra de arte um refúgio reflexivo diante do risco de o mundo se identificar com sua imagem mais banal. Por isso, os artistas modernos desenvolvem suas obras como um lugar absolutamente distinto do mundo e de qualquer imagem que pretenda se confundir com ele. ${ }^{89}$

Lorenzo Mammì ao comentar as ideias de espacialidade moderna do crítico de arte Clement Greenberg sintetiza de maneira mais precisa: "Um quadro moderno é um espaço outro que se opõe de modo irredutível ao espaço natural". ${ }^{90}$ A preservação desse

\footnotetext{
${ }^{87}$ Clark se vale do diagnóstico de Mark Mazower sobre a primeira metade do século XX, de promessas e catástrofes agigantadas. MAZOWER, Mark. Dark Continent: Europe's Tentieth Century. Londres: Penguin Group, 1998.

${ }^{88}$ CLARK, T.J. Picasso and truth: from cubism to Guernica. Princeton: Princeton University Press, 2013. p. 14.

${ }^{89}$ Curiosamente, essa é a mesma razão que Gerhard Richter declarará, para refazer fotografias domésticas em pintura. Segundo o artista: "[A pintura deve ser considerada] como uma realidade em si mesma, sem relação com realidade alguma, exceto ela mesma". RICHTER, Gerhard: "Interview with Irmeline Lebeer, 1973”. Em ELGER, Dietmar; OBRIST, Hans Ulrich. Gerhard Richter. Text: Wrintings, Interviews and Letters. Londres: Thames \& Hudson, 2009. p. 79. Ao contrário dos artistas modernos, esse mundo em si não contrasta com as formas de representação convencional. Ele reafirma os esquemas de representação como estruturas previamente dadas, independente de qualquer coisa. Na verdade, as reafirma. Como se nunca víssemos diretamente, mas por códigos que por vezes precisam ser anunciados, por vezes desbastados.

${ }^{90}$ MAMMİ, Lorenzo; “As bordas”. Em Companhia das Letras, 2012. p. 96. O que resta: arte e crítica de arte. São Paulo:
} 
espaço distinto da arte, que parece estimular a busca por formas mais complexas na pintura abstrata, também leva às considerações sobre a fotografia expostas anteriormente.

Segundo Thomas Crow, a resistência de Greenberg e de outros pensadores, como Adorno, às formas convencionais era a sua restrição criativa, ampliada pela ascensão de um gosto médio barateado, reproduzido pela indústria cultural, crescente no meio do século XX. Para Crow, o que preocupava Greenberg "era nada menos que uma crise material e social que ameaçou as formas tradicionais da cultura do século XIX de extinção. Essa crise era o resultado de uma indústria dedicada à simulação da arte sob a forma de mercadorias culturais reprodutíveis, isto é, a indústria da cultura de massa. Em busca de matéria-prima, a cultura de massa apropriou-se progressivamente das qualidades comercializáveis da arte tradicional, deixando como único caminho remanescente para a autenticidade um alerta permanente contra tudo o que fosse estereotipado e préprocessado". ${ }^{91}$ Trata-se de um esforço de distinção em um momento em que as artes aprofundam seus vínculos, como todos os outros produtos culturais, com o mundo do espetáculo.

A relação dessas obras modernas com a fotografia e com outras imagens acontece também sob essa chave. Segundo Simon Scharf, o que fará esse espírito baudelairiano, moderno, distinguir as artes da fotografia é o esforço para proscrever a representação pretensamente objetiva do naturalismo. Essa mentalidade moderna identifica na fotografia, segundo Scharf, o símbolo "mais visível e a mais tangível expressão de uma mentalidade que, para os espíritos rebeldes daquela época, era ofensiva". 92

\footnotetext{
${ }^{91}$ CROW, Thomas: Modern art and the common culture. New Haven: Yale University Press. p. 9. ${ }^{92}$ SCHARF, Aaron. Art and photography. Penguin Books, 1978 (reimpressão, $1^{\mathrm{a}}$ edição de 1968). p. 249.
} 


\section{Fotografia moderna}

Como foi dito anteriormente, os primeiros fotógrafos que se pensaram como artistas, entre o fim do século XIX e começo do século XX, também encontraram sentido expositivo nos seus trabalhos ao se aproximar das concepções de estilo, autoria ${ }^{93}$ e composição próprias das belas-artes. Na passagem do século XIX para o XX, a divisão das esferas do saber já começa a ficar clara, mas a fotografia ainda não tinha lugar determinado. Seu espaço discursivo podia estar no ramo do arquivo, da documentação, da geologia, da ciência, da tecnologia. Em um primeiro momento, os fotógrafos artistas, tal como os pintores, tentam escapar do análogo fotográfico ${ }^{94}$ buscando estratégias que fizessem com que a imagem não se parecesse com algo que pudéssemos ver.

Annateresa Fabris ao comentar o chamado pictorialismo de fotógrafos como Alvin Langdon (11), Alfred Stieglitz (até certo ponto) (12), Edward Steichen (14)e Henry Peach Robinson (13) fala da necessidade da fotografia emular a pintura para se afirmar como arte: “A fotografia, ao contrário, ao longo do século XIX, irá frequentemente escamotear suas qualidades fundamentais, tentando emular a pintura inclusive no campo da alegoria". ${ }^{95} \mathrm{Ou}$ "os fotógrafos partidários da fotografia de alta qualidade artística" enveredam francamente pelo caminho da alegoria, da imitação da pintura holandesa e

\footnotetext{
${ }^{93}$ Segundo Aaron Scharf, a questão da autoria aparece na fotografia e no seu questionamento como arte desde os seus primeiros anos. Diferentes intelectuais e artistas se perguntam: qual seria a intervenção ou manipulação do fotógrafo diante do seu referente? O que faria daquilo um trabalho de arte? Em 1861, o gravador e fotógrafo Menut-Alophe separa, como na Idade Média, os fotógrafos artistas e os fotógrafos mecânicos. Na mesma época, debates jurídicos sobre a autoria da foto também acontecem na Inglaterra. Cf. SCHARF, Aaron. Art and photography. Penguin Books, 1978 (reimpressão, $1^{\mathrm{a}}$ edição de 1968). p. 150-2.

94 BARTHES, Roland “A mensagem fotográfica”. Em O obvio e o obtuso. Trad. Isabel Paschoal. Lisboa: Edições 70, 2009.

${ }^{95}$ Em FABRIS, Annateresa. O desafio do olhar. v. I., São Paulo: WMF Martins Fontes, 2013. p. 17.
} 
inglesa, das expressões contemporâneas, compondo naturezas-mortas, cenas de gênero e religiosas e buscando inspiração em poemas e figuras literárias, lendárias e heroicas". ${ }^{96}$

Tal raciocínio vale para fotógrafos modernistas como Edward Weston, Tina Modotti, Aaron Siskind e Otto Steinert. ${ }^{97}$ No entanto, esses fotógrafos em vez de emular a tradição ou a pintura impressionista, aproximam-se da abstração e de linguagens modernas. ${ }^{98}$ Esses artistas distanciam-se da referência imediata ao reconhecível para trazer à fotografia algo de um exercício criativo menos limitado por condições de verossimilhança. A arte aqui era um trabalho na superfície da fotografia, começava onde o seu sentido utilitário terminava ${ }^{99}$. O potencial estético estava dado pela semelhança da imagem com as pinturas e esculturas. O objeto fotográfico autônomo tomava distância do referente para se aparentar com uma imagem idealizada.

A fotografia se modificou muito entre os séculos XIX e XX. Com as máquinas de clique instantâneo, sobretudo as máquinas portáteis e com visor, a técnica

\footnotetext{
${ }^{96}$ Idem, p. 18.

97 Jean- François Chevrier descreve a prática desses fotógrafos do século XX, que " desvincularam a arte fotográfica de uma estética naturalista derivada da prática funcional", como uma perspectiva já historicista da fotografia, que se aproveitava das características específicas próprias da técnica. Em CHEVRIER, Jean-François. "Advetures of the picture form in the history of photography". Em FOGLE, Douglas. The last picture show: Artists using photography: 1960-1982. Minneapolis: Walker Art Center, 2003. p. 117.

98 "Dentro da prática modernista da fotografia foram incorporadas não uma, mas duas tradições de prática e teoria abstracionistas que, em conjunto, são responsáveis por grande parte da fotografia que foi admirada como arte nos quarenta anos entre 1920 e 1960. Em uma margem temos o purismo insistente de Alfred Stieglitz, afirmando que as fotografias, para serem arte, devem alcançar o plano da metáfora mesmo aderindo a ideias estritas sobre aparições fotográficas. Na outra margem, temos o exemplo da fotografia europeia praticada nas décadas de 1920 e 1930 na Alemanha, na Bauhaus; na França, pelos surrealistas; e na União Soviética, pelos construtivistas. Para simplificar uma história complexa, artistas como Alexander Rodchenko, Lászlo Moholy-Nagy e Man Ray trataram a fotografia como uma investigação experimental, usando-a para remodelar a experiência óptica em termos completamente"modernos". GRUNDBERG, Andy. "The representation of abstraction/The abstraction of represetation". Em Crisis of the real. Nova York: Aperture Foundation. p. 160.

${ }^{99}$ WALL, Jeff: "Marks of Indifference" em Selected Essays and Interviews. Nova York, The Museum of Modern Art, 2007 (p.147).
} 
ganha outro sentido. Nos anos 1930, de acordo com Jean-François Chevrier, a fotografia passa a ser estudada com interesse renovado. ${ }^{100}$

Segundo Chevrier, em países de língua alemã surgem os primeiros estudos em que a história da fotografia é dissociada da história da arte. Heinrich Schwarz publica a primeira monografia sobre um fotógrafo em 1932. ${ }^{101}$ Nos Estados Unidos, a primeira história da fotografia é publicada em 1937. O volume é organizado por Beaumont Newhall, para uma exposição no Museum of Modern Art (Moma), de Nova York. A partir dali o debate em torno da fotografia se modifica. Fotógrafos e intelectuais procuram as qualidades estéticas da fotografia em aspectos próprios da técnica. A busca é por uma autonomia da imagem, distinta de sua semelhança com formas de arte mais antigas. ${ }^{102}$

Tais concepções abriram o caminho para uma fotografia que registrava fragmentos do mundo de maneira mais realista. Os artistas que criaram o fotojornalismo pensam o esforço documental como um esforço criativo. Em seu ensaio seminal, "O instante decisivo", o fotógrafo Henri Cartier-Bresson afirma que, ao fotografar momentos efêmeros, o fotógrafo de reportagens deve “tomar decisões" com o olho. Essa composição instantânea procura fissuras momentâneas que se revelariam a reconfiguração de uma paisagem visível dada por um ato, um fenômeno ou uma relação inusitada.

\section{Para Bresson:}

\footnotetext{
100 CHEVRIER, Jean-François. “Advetures of the picture form in the history of photography”. Em FOGLE, Douglas. The last picture show: artists using photography, 1960-1982. Minneapolis: Walker Art Center, 2003. (Publicado originalmente em francês, em 1989.) p. 116.

101 Idem.

102 "A ideia fortemente hegeliana de Riegl de Kunstwollen, ou "impulso artístico", foi retomada por [Beaumont] Newhall [curador da primeira grande mostra de fotografia do Moma], que a usou para postular que a história da fotografia procedia primeiro da necessária invenção de uma ferramenta artística, seguida pelo desenvolvimento, não menos necessário, de um estilo em conformidade com essa ferramenta. (...) Segundo esse modelo, o pictorialismo como a assimilação da fotografia nas artes plásticas e a sujeição da técnica de registro aos paradigmas pictóricos representam um ponto de crise na culminação de um estilo.” Idem, p. 116-7.
} 
A fotografia é (...) o reconhecimento, na realidade, de um ritmo de superfícies, de linhas e de valores; o olho recorta o tema, e a câmera tem apenas que cuidar do seu trabalho, imprimir sobre o filme a decisão do olho. Uma foto se vê em sua totalidade, de uma só vez, como um quadro; a composição é uma coalizão simultânea, uma coordenação orgânica de elementos visuais. Não se compõe gratuitamente, é preciso que haja uma necessidade, e não há como separar o fundo e a forma. $\mathrm{Na}$ fotografia, se dá uma plástica nova, função de linhas instantâneas; trabalhamos em meio ao movimento, numa espécie de pressentimento da vida, e a fotografia deve captar o equilíbrio expressivo em meio ao movimento. ${ }^{103}$

Aqui, a arte se reconcilia com o caráter realista da fotografia. Esse caráter tem sentido forte. Ele não é conquistado a partir da captura objetiva e sem intermediários da imagem, mas pela construção da composição, feita pela decisão do fotógrafo em escolher um enquadramento, uma luz específica que enfatize determinadas relações presentes diante dele.

No tipo de fotografia defendido por Cartier-Bresson, o "artístico" surge no que há de mais específico em sua técnica. Ele pretende documentar um acontecimento em um lugar reconhecível. No entanto, o sentido estético aparece não na descrição dos elementos visíveis, mas na relação entre alguns elementos, que se não fosse enfatizada na imagem, passaria despercebida. Um gesto, um modo da luz bater, uma relação entre o personagem e seu entorno. Essa relação abre algum tipo de fratura, permitindo que a imagem provoque um encontro renovado com o real. Tal concepção de instante decisivo

\footnotetext{
${ }^{103}$ CARTIER-BRESSON, H. “O instante decisivo.” Trad. Samuel Titan Jr. Revista Zum, n. 1, São Paulo, Instituto Moreira Salles, out. 2011, p. 149.
} 
guarda semelhanças com a ideia surrealista de André Breton de "acaso objetivo", aquelas ocorrências inesperadas que nos fazem perceber uma situação impensada, promovendo o que é chamado de "deslocamento factual". ${ }^{104}$

O significado de arte de Cartier-Bresson parece ser consequência de valores específicos do modernismo histórico. A fotografia aqui diz algo a mais do que uma descrição obediente do visível. O fotógrafo resistia ao anedótico o quanto podia. ${ }^{105} \mathrm{O}$ que importa a ele é capturar relações novas, não percebidas e inusitadas, o registro de um momento que não se repetirá. O sentido, portanto, é de uma associação, espontânea, que registra com apuro estético uma experiência única, insubstituível e reveladora.

Como na obra moderna, a fotografia para Cartier-Bresson procura a originalidade, tenta perceber o mundo de maneira diferente da percebida pelo olhar comum sobre os objetos. Seu trabalho pretende certa espontaneidade e busca construir um estilo próprio e inconfundível. Assim, mesmo que reconhecendo a especificidade de seu meio, aliás, inclusive por isso, Cartier-Bresson também opera dentro dos marcos da arte moderna. Mais que isso, reivindicando certa distinção de sua imagem de formas de representação visual ordinárias. Essa dissonância em relação à experiência ordinária parece permear boa parte da obra moderna.

\section{Pós-guerra}

Essa relação da fotografia com a arte começa a se modificar a partir dos anos 1950. Na segunda metade do século XX, alguns trabalhos de arte passam não só a se inspirar em modelos e temas saídos da cultura de massa, mas a copiá-los. Em lugares

\footnotetext{
${ }^{104}$ CHENIEUX-GENDRON, Jacqueline. O surrealismo. Trad. Mario Laranjeira. São Paulo: Martins Fontes, 1992. p. 95.

105 “Cartier-Bresson (...) sob o feitiço do surrealismo, lança sua rede para capturar justaposições surpreendentes e casualidade momentânea. Em última análise, suas fotografias perduraram por causa de suas composições complexas, não pelos méritos do seu assunto. Em GRUNDBERG, Andy. "Magnum's postwar paradox”. Em Crisis of the real. Nova York: Aperture Foundation. p. 192.
} 
diferentes, por motivos diferentes, artistas abriam mão de uma aparência da obra inédita, complexa e avessa à banalidade e mergulhavam na platitude do que existe de mais comum e ordinário.

Aparecem jovens artistas desinteressados em discursos mais esotéricos da arte na França, na Inglaterra, na Alemanha e nos Estados Unidos. É a primeira geração de artistas a despontar na segunda metade do século, com uma experiência histórica e uma compreensão da arte moderna completamente nova. A eles, pouco interessa preservar a relação de contemplação tradicional. Por isso, muitos vão se interessar pelo caráter niilista do Dadá, outros por novas formas de representação visual saídas do cinema, da fotografia, da publicidade.

Algo dessa mudança é percebido como uma recusa à ideia de distinção da experiência artística, a crítica da contemplação como ato reflexivo por excelência. O caráter específico, de transformação do referente, da representação modernista será questionado em diversas latitudes. Essa recusa aparece, por exemplo, na crítica de Yves Klein à forma intrincada da abstração tachista e ao discurso lírico de seus defensores; ${ }^{106}$ do outro lado do Atlântico, aparece no gesto iconoclasta de Rauschenberg quando apaga um desenho de Willem de Kooning. ${ }^{107}$

Klein tinha uma história familiar por trás da sua repulsa ao discurso lírico. Era filho da pintora abstrata Marie Raymond ${ }^{108}$ e conviveu com a narrativa da

\footnotetext{
${ }^{106} \mathrm{O}$ artista fala sobre a abstração lírica: "Eu desprezo artistas que se descarregam em suas pinturas, como ocorre hoje, com frequência. Que mórbido! Em vez de pensar no belo, no bom, no verdadeiro, eles vomitam, ejaculam, cospem toda a sua horrível complexidade, apodrecida e infecciosa, em suas pinturas, como se fosse para se desonerar e atirar o peso nos 'outros', 'os espectadores' do trabalho, com toda a carga de sua frustração e amargura ressentida". Citado em BOIS, Yves-Alain. "A relevância de Klein hoje." ARS, v. 8, n. 15, São Paulo, 2010. p. 61.

${ }^{107}$ Em ambos os casos, a recusa se dá pelo uso do monocromo.

${ }^{108}$ De acordo com Yve-Alain Bois, os primeiros monocromos de Klein "eram, acima de tudo, gestos parricidas, que de modo algum haviam sido concebidos como trabalhos de arte”. BOIS, Yves-Alain. "A relevância de Klein hoje.” ARS, v. 8, n. 15, São Paulo, 2010. p. 62.
} 
espontaneidade e do sofrimento da pintura abstrata informal desde os seus primeiros anos. Por conta de essa pintura prometer mais do que entregava e por conviver com uma crise existencial vazia, ao ver de Klein, ela era mistificadora. Por isso, ele mesmo se torna um "místico e mistificador", ${ }^{109}$ nos dizeres de Thierry de Duve. Um artista que faz do fetiche em torno de uma espacialidade misteriosa um espetáculo. Para salvar a obra de Klein de uma crítica que o vê como um bufão da indústria cultural, ${ }^{110}$ Yve-Alain Bois afirma que a qualidade de Klein seria uma dissimulação. O artista "nos mostra como desmoralizar o espetáculo da indústria cultural encenando um ardil ainda maior que o dela". ${ }^{111}$

Muitos intelectuais, militantes e artistas, foram mais longe na aproximação entre alta cultura e indústria cultural. Um deles foi Guy Debord. Contemporâneo de Yves Klein, ${ }^{112}$ Debord, que vinha de uma tradição surrealista e marxista, funda em 1957 a sua Internacional Situacionista.

Em seu A sociedade do espetáculo, de 1967, ele afirma que a cultura se tornou "a mercadoria vedete da Sociedade do Espetáculo". ${ }^{113}$ Ela abrira o caminho para o consumo das "ideias", que, para Debord, desempenharia papel semelhante ao do automóvel na valorização do capital das sociedades contemporâneas. ${ }^{114}$ A ideia de um produto imaterial de valor intangível. As vanguardas não ofereceriam resistência a esse modo de ordenação, tampouco problematizariam seus significados. Na verdade, elas seriam "a tendência mais moderna da sociedade do espetáculo". ${ }^{115}$

\footnotetext{
${ }^{109}$ DUVE, Thierry de. "Yves Klein, or the dead dealer". Em Sewn in sweatshops of Marx: Beuys, Warhol, Klein, Duchamp. Chicago: The University of Chicago Press, 2012. p. 42.

${ }^{110}$ BUCHLOH, Benjamin. "Plenty or nothing: from Yves Klein's Le vide to Arman's Le plein (1998)". $\mathrm{Em}$ _. Neo-avantgarde and Culture Industry: essays on European and American Art from 1955 to 1975. Cambridge: MIT Press, 2000. p. 259.

${ }^{111}$ BOIS, Yves-Alain. "A relevância de Klein hoje”. ARS, v. 8, n. 15, São Paulo, 2010. p. 72.

${ }^{112}$ Segundo Yve-Alain Bois, eles conviveram por um tempo, depois romperam. Idem, p. 66.

${ }^{113}$ DEBORD, Guy: A Sociedade do Espetáculo. Trad. Estela dos Santos Abreu. Rio de Janeiro:

Contraponto, 1997. p. 126. Fragmento 193.

${ }^{114}$ Idem, p. 127.

${ }^{115}$ Idem, p. 126.
} 
Para Debord, a especialização autorreferente da arte autônoma a interditaria a criatividade de reorganizar a cultura e a linguagem e de atuar diretamente na história. Ao concentrar-se na investigação de questões internas, em que a história da arte é separada do resto da história, a arte torna-se o que Debord chama de "representação ilusória do não vivido". ${ }^{116}$

Independente da consistência do argumento, o que é relevante para nós é a associação feita a partir de então entre as vanguardas modernas e a indústria cultural. A oposição entre vanguarda e kitsch, para membros dessa geração que desponta no pósguerra, já não parecia fazer o mesmo sentido de antes.

Por isso, a busca por uma forma intrincada para alguns artistas do Atlântico Norte era uma preocupação das gerações anteriores. A geração que nasce na grande depressão, cresce com a guerra e se torna adulta na consolidação da hegemonia americana denuncia o envelhecimento dos projetos de futuro das gerações imediatamente anteriores. Embora expressassem admiração pelo modernismo, passam a contestar alguns de seus discursos.

Não custa lembrar que àquela altura já existiam instituições catalogando, organizando, pensando cronologicamente o modernismo há décadas. A defesa de uma arte mais radical formalmente já não era novidade e nem precisava do esforço de legitimação de décadas anteriores. A arte tradicional, bem como as categorias mais tradicionais da sociedade, pareciam estar se despedindo naquele período do capitalismo avançado. A ideia de resíduos que atariam as pessoas ao passado vai se tornando uma ideia cada vez mais distante.

\footnotetext{
${ }^{116}$ Idem, p. 121.
} 
É nesse momento também que o chamado "cubo branco" se consolida como o espaço expositivo das galerias e museus. A arquitetura realiza o ideal modernista de isolamento da obra para contemplação em paredes brancas e grandes intervalos entre uma parede e outra. Lorenzo Mammì afirma que é durante o aparecimento dessas neovanguardas que esse tipo de espaço se consolida. ${ }^{117}$

A juventude se forma como categoria social potente no Hemisfério Norte. Surge no pós-guerra como a principal consumidora de uma produção cultural de massa, uma indústria de crescente importância no capitalismo tardio. Essa produção era totalmente moldada na indústria. Uma indústria que se refaz com o esforço de guerra e se generaliza por todo o Atlântico Norte. Parte dos símbolos distintivos dessa nova categoria social estão ligados à produção industrial e à vida urbana, em oposição à tradição do artesanato e à vida rural.

A cultura dos jovens e sua imagem refletida surgia nos filmes, na literatura pulp, de ficção científica, terror, mistério e nos romances água com açúcar. Surgia também nas peças de design, nas revistas, na moda, mas, sobretudo, na televisão e nas histórias em quadrinhos. Apesar de algumas dessas linguagens manterem o tradicionalismo kitsch, muitas eram modernas desde o nascimento. ${ }^{118}$ Essas linguagens são pensadas e estudadas em um período de vertiginosa expansão universitária em boa parte do mundo. ${ }^{119}$

\footnotetext{
117 “Os rituais de apresentação da arte moderna, elaborados a partir do modernismo clássico e da escola de Nova York, tornam-se mais importantes do que nunca. Na verdade, é justamente na década de 1960, a partir do momento em que passa a ser criticado, que o espaço neutro modernista, em fase de definição há duas décadas, adquire o seu significado pleno." MAMMİ, Lorenzo. "As bordas". Em O que resta: arte e crítica de arte. São Paulo: Companhia das Letras, 2012. p. 95.

${ }^{118}$ Talvez o exemplo mais bem-acabado dessa linguagem industrial moderna seja os quadrinhos dos anos 1930.

${ }^{119}$ CROW, Thomas. The long march of pop: art, music and design, 1930-1995. New Haven: Yale University Press, 2014. p. 117-119.
} 
Para além disso, uma nova relação com a imagem se estabelece. Boa parte das pessoas entra em contato com as obras de arte modernas por suas representações fotográficas. Progressivamente, as pessoas passam a saber das notícias do mundo e a conhecer seus ídolos através da imagem. Aliás, desde o início do século XX, sabe-se que algo aconteceu pela imagem da fotografia.

A partir de 1936, abre-se o caminho para uma relação doméstica com a imagem em movimento. No dia 2 de novembro daquele ano, a $\mathrm{BBC}$ faz a primeira transmissão televisiva da história. Em 1939, a televisão chega a outros países da Europa e aos Estados Unidos. ${ }^{120}$ Embora, as transmissões tenham sido interrompidas na Europa durante a Segunda Guerra, elas se ampliam nos Estados Unidos. A expansão se dá de fato com a prosperidade americana dos anos 1950. De 1950 a 1955, o número de lares com televisores nos Estados Unidos cresce de 3,9 milhões para 30,7 milhões. Por conta do novo sistema norte-americano de telecomunicações, a televisão torna-se onipresente depois da guerra. ${ }^{121}$

A produção de imagens ganha uma escala inédita. Alguns artistas resolvem lidar com esse universo das imagens que se multiplicavam do cinema para a TV, dela para as revistas, para os produtos de supermercado. As relações do capitalismo avançado são todas permeadas por essas imagens midiáticas produzidas industrialmente. Essas representações visuais parecem não mais dialogar com a história da arte ou com a história da fotografia, mas atendem interesses comerciais, preocupam-se com os números da audiência e chegam a um público gigantesco.

\footnotetext{
${ }^{120}$ WILLIAMS, Raymond: Televisão: tecnologia e forma social. São Paulo. Boitempo: Belo Horizonte, PUC-MG, 2016. p. 41.

${ }^{121}$ PAUTZ, Michelle. "The Decline in Average Weekly Cinema Attendance". Issues in Political Economy, 2002, v. 11. Disponível em: http://org.elon.edu/ipe/pautz2.pdf. Acesso em: jan. 2016.
} 
Estabelece-se uma nova relação com a imagem. Ela é generalizada nos meios de comunicação e cria ficções sobre o noticiário, a propaganda, as disputas políticas e a vida das pessoas famosas. John J. Curley - a partir da frase de Marshall McLuhan, de que "a Guerra Fria foi uma batalha elétrica de informações e imagens" - afirma que a ubiquidade dessas imagens, como forma onipresente de contato com a realidade, fazia com que as certezas sobre os acontecimentos se turvassem (21). ${ }^{122}$ A relação da imagem com o seu referente se torna ambígua. Por conta dessa ambiguidade, alguns artistas decidem se dedicar a essas representações e passam a trabalhar a partir do material pronto desses meios de comunicação homogêneos, onde tudo é parecido com a publicidade

Alguns artistas pensam sua prática tal como pensam as outras representações visuais. Nos anos 1970, não só a crítica deixa de questionar o caráter artístico da fotografia, já que isso não era mais um problema, ${ }^{123}$ como passa a tentar entender o caráter fotográfico da arte contemporânea. ${ }^{124}$

Segundo Jean-François Chevrier, a aproximação contemporânea entre a arte e a fotografia, no caso específico da interpretação de Jean Clair, da contraposição do fotográfico como superior ao artístico, ${ }^{125}$ parte das experiências conceituais de se diluir a obra em registros de ações diretas na vida. A obra seria a ação, o acontecimento; a fotografia seria o veículo da informação desse ato em processo. ${ }^{126}$ Segundo Chevrier, para os artistas associados à arte conceitual $(92-97)$,

\footnotetext{
${ }^{122}$ CURLEY, John J. A Conspiracy of Images. New Haven/Londres: Yale University Press, 2013. p. 8. ${ }^{123}$ DUBOIS, Philippe. O ato fotográfico e outros ensaios. Trad. Marina Appenzeller. Campinas: Papirus, 1993. p. 254.

${ }^{124}$ Rosalind Krauss fala de uma "calibragem fotográfica" da arte contemporânea, que agora, sob a influência de Marcel Duchamp, faz da imagem uma espécie de índice de algo existente a atuar no mundo. Cf. KRAUSS, Rosalind. "Os espaços discursivos da fotografia". Em O fotográfico. Barcelona: Gustavo Gili, 2002. p. 16.

${ }^{125}$ CHEVRIER, Jean-François. "Advetures of the picture form in the history of photography". Em FOGLE, Douglas. The last picture show: artists using photography, 1960-1982. Minneapolis: Walker Art Center, 2003. p. 113.

${ }^{126}$ Idem, p. 114.
} 
a fotografia se tornara extremamente útil como uma técnica de registro e um meio de informação. Produziria meros documentos e não trabalhos autônomos, não seria necessário se endereçar ao espectador (observador) para aludir à ideia, ação e processo desenvolvido pelo artista. Uma imagem já não era oferecida nem em si, para o prazer público, nem para a liberdade de percepção ou interpretação; em vez disso, era produzida para que o público pudesse, através dela, descobrir e reconstituir uma abordagem, uma experiência (no sentido científico), um procedimento ou um sistema. ${ }^{127}$

A imagem apropriada e desenvolvida não é artística nem no sentido tradicional e nem no sentido moderno. A partir dos anos 1960, alguns artistas invertem a relação entre arte e fotografia, na qual o modo de funcionamento da pintura ou da escultura norteavam o sentido da fotografia para exposição. Alguns trabalhos contemporâneos procuram emular as imagens mais ordinárias, produzidas de acordo com os critérios dos meios de comunicação de massa.

O que nos importa aqui, é que alguns artistas contemporâneos parecem inverter mesmo os princípios de grupos industrialistas da arte, como o De Stjil, a Bauhaus e a Escola de Ulm. Ali, a técnica artística pretendia transformar a produção industrial. A arte humanizaria e transformaria os modos de trabalho. Na produção que estudaremos, os artistas mimetizam as técnicas reprodutíveis, muitas vezes, diluindo sua obra em outros objetos do mundo. A obra perde a especificidade que possuía ao menos desde o século XVIII.

\footnotetext{
${ }^{127}$ Idem, p. 120.
} 
Muito da relação com a imagem se modificou na produção artística. Nos capítulos seguintes, pretende-se descrever diferentes momentos dessa relação da imagem com um novo repertório de "imagens-produto". Primeiro, falaremos de como o trabalho de Andy Warhol procura diluir a obra de arte em outras formas de produção de imagem.

Depois, migraremos para a Alemanha, no capítulo central deste trabalho, para estudar a assimilação do pop por Gerhard Richter, que a interpreta como mais uma convenção engessada. $\mathrm{O}$ artista parece procurar um significado novo para a pintura depois de ela ser completamente inserida no mundo das imagens reprodutíveis. 


\section{CAPÍTULO 2}

Repetition in the music and we're never going to lose it President Carter loves repetition Chairman Mao he dug repetition Repetition in China Repetition in America Repetition in West Germany Simultaneous suicides

(MARK E. SMITH) $^{128}$ lançada no compacto "Bingo-Master's Break-Out! ”, em 1978. 
A obra de Andy Warhol é exemplar de uma mudança na relação da pintura com as imagens produzidas por meios mecânicos na segunda metade do século XX. Diz respeito ao modo como artistas começaram a se apropriar de material impresso, fotográfico, cinematográfico e de vídeo depois da era da televisão. A apropriação não era novidade. As vanguardas do século XX se valeram do cinema, da fotografia, de objetos retirados de outro lugar. Warhol, no entanto, radicaliza e leva esse processo para outra direção - faz com que a obra de museu aspire a ser um objeto mercantil ordinário, uma “imagem-produto". ${ }^{129}$

Neste capítulo, pretende-se organizar as variações de significado que essas imagens produzidas em outros campos tiveram no trabalho de Andy Warhol. Embora seja possível traçar uma trajetória linear dessa noção em sua obra, ela é cheia de desencontros e desvios. Pretendemos nos ater às razões para Warhol trabalhar com esse tipo de imagem e às contribuições que o artista traz para a compreensão do novo regime de imagens que passa a vigorar com os meios de comunicação de massa, a urbanização acelerada, as mudanças no capitalismo depois da hegemonia americana com o Plano Marshall e a Guerra Fria.

No capítulo anterior, verificamos algumas interpretações que davam conta da relação das artes plásticas de exposição com novos regimes de imagem. Meios gráficos, fotográficos, cinematográficos atuaram como uma espécie de alter ego da arte moderna desde o século XIX. A arte que pretendia ser mais reflexiva, questionadora das 
convenções da pintura e queria reordenar suas formas, muitas vezes recorreu à fotografia ou a outros espaços discursivos ${ }^{130}$ de criação de imagem como modelo ou algo a se contrapor.

Essas imagens eram vistas às vezes como diluição das convenções reconhecíveis na arte ou um novo sistema de códigos que em nada se relacionava com ela. Na arte moderna, alguns artistas quiseram manipular esses códigos e atribuir sentido estético a eles. O sentido estético era dado pela relação reflexiva e contemplativa com o objeto, não pela comunicação e pelos códigos de mensagem dos meios de comunicação de massa. O que parece acontecer com a pop art é o inverso.

Aqui falaremos de sua ressignificação pela produção artística dos anos 1960 nos Estados Unidos. A imagem ganhou novos usos, novos sentidos sociais depois das duas grandes guerras mundiais, da invenção do fotojornalismo, das novas suspeitas criadas em relação à fotografia ${ }^{131}$ e das promessas frustradas da modernidade. Warhol não é o único, mas talvez seja o artista que tenha problematizado de maneira mais radical a mediação das relações estéticas pela multiplicação de imagens, pelo mass media e sua reprodutibilidade. Ele indica de forma marcante uma nova relação com a arte e com a própria subjetividade.

1.

$130 \mathrm{O}$ conceito de espaços discursivos sai da importante interpretação de Rosalind Krauss. Em KRAUSS, Rosalind; $O$ Fotográfico. Barcelona: Gustavo Gili, 2002. p. 41. No decorrer do texto, a intelectual chega a falar da relação entre fotografia e arte como a de dois campos distintos que se influenciam mutuamente. 131 CURLEY, John J. A Conspiracy of Images. New Haven/Londres: Yale University Press, 2013. p. 8. 
Warhol decidiu radicalizar o aspecto gráfico de suas pinturas por volta de 1962. A sugestão foi dada por seus amigos Emile De Antonio ${ }^{132}$ e Ivan Karp. ${ }^{133}$ Segundo Hal Foster, quando Emile De Antonio viu que Warhol pintava duas telas da mesma garrafa de Coca-Cola, uma com marcas de gestualidade, outra inteiramente gráfica, disse que era perda de tempo ele se dedicar ao gestual. Para De Antonio, o trabalho tinha de buscar a experiência do produto. O interesse era a identificação completa da representação com a imagem reconhecível que lhe servia de motivo ${ }^{134}$. Embora não tenha destruído a tela gestual, como sugeriu De Antonio, Warhol só expôs a versão gráfica.

Warhol pintará cada vez mais à semelhança dos impressos, das embalagens e dos projetos gráficos. Seus quadros grandes são ainda mais gráficos que suas ilustrações, feitas de desenhos irregulares e impressões falhadas de carimbo. Aliás, mais tarde, ele insistirá no caráter reprodutível da pintura e se dedicará a refazer a mesma imagem diversas vezes, como quem afirma que aquele quadro individual não é um original.

A imagem da pintura daí em diante não poderia emular afetações gestuais, mas deveria ser mecânica, precisa como a prensa gráfica. Warhol evita as marcas de pincelada, apagamentos, rasuras e tudo o que parece pintura (27-28). Trabalha o gesto artístico como repetitivo, reiterativo e mecânico. O artista se reinventa como pintor mergulhando em um mundo de imagens reprodutíveis sempre idênticas. Como ele mesmo afirmou depois: "Eu queria uma coisa mais forte, que produzisse o efeito de uma linha de

132 Cf. WARHOL, Andy; HACKETT, Pat. Popismo: os anos 60 segundo Warhol. Trad. José Rubens Siqueira. Rio de Janeiro: Cobogó, 2013. p. 13. Emile de Antonio era nessa época, o seu interlocutor privilegiado a respeito dessas questões. Antonio era um agitador cultural das vanguardas de Nova York. Organizou exposições de Johns, Rauschenberg e Larry Rivers. Mais tarde, ele se tornaria um dos grandes documentaristas da esquerda norte-americana.

133 WARHOL, Andy; HACKETT, Pat. Popismo: os anos 60 segundo Warhol. Trad. José Rubens Siqueira. Rio de Janeiro: Cobogó, 2013. p. 14-18; e KARP, Ivan. “Andy Starts to paint”. Em GOLDSMITH, Kenneth. (Org.) Andy Warhol Giant Size. Londres/Nova York, 2006. p. 86. 134 FOSTER, Hal. The first pop age. Princeton: Princeton University Press, 2012. p. 120. 
montagem". ${ }^{135}$ Assim, se ele possuía um estilo inconfundível na ilustração, agora o estilo precisaria ser apagado. Os seus trabalhos passam a evitar qualquer traço de personalidade. Imitam exatamente o seu tema: uma imagem ordinária, reprodutível e esquemática.

Naquela época, em Nova York, nada poderia ser mais distante do sentido da arte do que a estética do produto pronto, sem originalidade, sem distinção, que sempre seria o mesmo. A arte do expressionismo abstrato procura relações inéditas feitas por gestos espontâneos. Segundo Thomas Crow, são apostas distintas. “A aposta de geração de Pollock era que os momentos imprevisíveis de espontaneidade poderiam preceder e constituir, em última análise, o ato de construção [da composição]". ${ }^{136}$

Warhol radicaliza a aparência de não originalidade, de cópia e de simulação em suas pinturas. Usa os temas mais ordinários possíveis: geladeiras, dólares e latas de sopa. E se os artistas do expressionismo abstrato como Pollock e Rothko insistiam na construção de uma forma que não se identificava com nada, que evitava qualquer caráter afirmativo, a pintura de Warhol era pura identidade. Aliás, nem se identificava com um objeto qualquer, mas imitava sua imagem. É uma pintura que imita um símbolo, que imita outra imagem. Tantas ordens de representação se sobrepunham que mal víamos o objeto.

A decisão de figurar esses temas não era trivial àquela época. Sobretudo, da maneira como o artista fazia. Mas também não era exatamente nova. Warhol já conhecia e admirava a distância a obra de artistas que se apropriavam de códigos visuais saídos de outros universos, mais especificamente, de artistas que se valiam de símbolos legíveis e

135 WARHOL, Andy; HACKETT, Pat. Popismo: os anos 60 segundo Warhol. Trad. José Rubens Siqueira. Rio de Janeiro: Cobogó, 2013. p. 34.

136 CROW, Thomas. The long march of pop: art, music and design, 1930-1995. New Haven: Yale University Press, 2015. p. 79. 
reconhecíveis. ${ }^{137}$ Tão reiteradamente reconhecíveis que pareciam não ter autor: como os alvos e bandeiras dos Estados Unidos, de Jasper Johns.

Os trabalhos chamados de neodada, ou neorrealistas, partiam de um acervo previamente coletado. Os artistas trabalhavam sobre um imaginário popular reconhecível e difuso em suas obras. O trabalho de Jasper Johns e de Robert Rauschenberg consistia em relacionar imagens de um imaginário previamente dado. A ideia forte aqui é a de símbolos facilmente reconhecíveis pelo "homem comum"138. Embora muito distante do imaginário pop, da cultura de massa, a pintura gira em torno de uma estrutura pronta de fácil identificação.

Thomas Crow associa a formação desse repertório das formas de Rauschenberg e de Johns a um esforço modernista americano que transcende a contraposição à estética da pintura expressionista-abstrata. Em seu livro de 2015, ${ }^{139}$ Thomas Crow comenta como esse repertório que antecede a pop - e a influencia - foi constituído em paralelo à formação de um conceito de cultura popular que tentava definir o significado de sociedades tradicionais que se tornavam marginais ao longo das drásticas mudanças da sociedade da industrialização maciça dos Estados Unidos ao longo do século XX.

Segundo Crow, tal uso, sobretudo na arte americana, acompanha a formação de um repertório de formas reconhecíveis associado ao imaginário popular. Isso é

137 Em Popismo, Warhol narra em diversos momentos o esforço feito por ele e por Emile De Antonio para obter atenção e respeito de Jasper Johns e Robert Rauschenberg. WARHOL, Andy; HACKETT, Pat. Popismo: os anos 60 segundo Warhol. Trad. José Rubens Siqueira. Rio de Janeiro: Cobogó, 2013. Na ótima biografia de Warhol, Victor Bockris conta que tanto Johns quanto Rauschenberg repeliam Warhol, inclusive por ele ser afeminado. Embora fossem gays, não gostavam de ser identificados como tal e mantinham um tipo de masculinidade viril da geração anterior de pintores. Cf. BOCKRIS, Victor. Warhol: The Biography. Boston: Da Capo Press, 2003. (E-book, entrada 46\%).

138 Essa é uma rica discussão do período, animada tanto por folcloristas como por curadores do primeiro modernismo americano, como Alfred Baar e Holger Cahill. Alfred Baar fala de seu "compromisso igualitário com a arte do homem comum". CROW, Thomas. "Alias: Smith and Johns". Em long march of pop: art, music and design, 1930-1995, New Haven: Yale University Press, 2015. The 139 Idem. 
relacionado ao esforço intelectual de criação de grandes acervos de música popular, organizados por Charles Seeger, John Lomax, Alan Lomax e Harry Smith, como a tentativa de capturar arquivos da vida popular castigada pela miséria rural da Grande Depressão e da vida das pessoas comuns. Como expressões visuais vigorosas, Crow menciona as reportagens de fotógrafos como Dorothea Lange e Walker Evans e a formação e o estudo de coleções de arte popular iniciadas por Holger Cahill e Alfred Baar, em instituições como o Museum of Modern Art (Moma), de Nova York. Em um os modos de vida eram documentados e ficcionalizados; em outro formava-se um repertório visual da iconografia das pessoas comuns, aliás, com bandeiras e mapas (166-168). ${ }^{140}$

Johns cria a partir da combinação e da manipulação desses símbolos amplamente reconhecíveis. Como Crow formula:

Mudanças calculadas juntamente com combinações e recombinações repetidas operam no corpo das obras de Johns ao longo do tempo e de peça para peça. Elas criam constelações que surgem e se desenvolvem em um processo dinâmico que esvazia os imperativos estéticos por uma síntese formal definitivamente unificada. ${ }^{141}$

Essa iconografia feita de signos coletados aqui e ali e legíveis é trabalhada em uma pintura formalmente muito complexa. A pintura de Johns é feita com encáustica e tinta óleo. A encáustica não é uma técnica de grande prestígio na arte moderna, mas foi importante para Johns conseguir os seus resultados. Sua pintura inicial é feita de uma gestualidade marcada, reforçada pela viscosidade encáustica.

${ }^{140}$ Idem.

141 Idem, p. 52. 
Johns pinta suas telas como uma superfície animada de gestos, que apontam para várias direções. A composição indica um campo irregular e heterogêneo. As cores são contrastadas e não naturalistas, e as formas são planas, tudo como na pintura do expressionismo abstrato. No entanto, apesar das características comuns, os resultados são diversos. As pinceladas dispersas e multidirecionais não organizam um espaço complexo de relações formais diversas. O esforço resulta na figuração de objetos ordinários como alvos, bandeiras dos Estados Unidos, mapas, números e letras. Os quadros por vezes são tão parecidos que se confundem com os objetos. Como cita Leo Steinberg em seu clássico texto sobre Johns: "coisas que a mente já conhece"142. Então, a ordenação das pinceladas configura não uma nova forma, mas um objeto banal.

Tanto o significado da forma, quanto o significado dos ícones pintados se modificam na pintura. Aquilo é tanto uma pintura, como um símile de um objeto que qualquer americano comum seria capaz de identificar. $\mathrm{O}$ artista fala explicitamente que gostaria de ver como signos que todos reconhecem podem ser pensados de maneira distinta em contextos diversos. ${ }^{143}$

Na pintura de Johns, tanto as figuras, quanto os gestos estão, de alguma maneira, deslocados. Há uma espécie de deslizamento duchampiano no significado das partes e da imagem final configurada. A forma abstrata acaba conformando uma estrutura reconhecível. Por isso, se o caráter gestual, expansivo e plano da pintura tem no expressionismo abstrato um sentido ideológico, associado à liberdade e a espontaneidade, aqui esse sentido se perde. Não se conquista uma libertação das amarras da racionalidade, não se encontra o impensável, a beleza transcendental a uma entrega aos gestos. Os gestos

142 STEINBERG, Leo. "Jasper Johns: os sete primeiros anos de sua arte”. Em Outros Critérios. São Paulo: Cosac Naify, 2008. p. 54.

143 Citado em VARNEDOE, Kirk. "Introduction: a sense of life". Em Jasper Johns: a retrospective. Nova York: The Museum of Modern Art, 1996. (p. 34). 
encontram as convenções mais convencionais possíveis. Na pintura de Jasper Johns, esse modo de formalizar é associado a estruturas elementares, esquemáticas.

Robert Morris, um dos pioneiros do minimalismo, chama Johns de code breaker. ${ }^{144}$ Para Morris, o artista teria tomado símbolos antitéticos da liberdade americana (um no plano artístico, outro no plano patriótico ou imperial) e os teria superposto no mesmo lugar, até o ponto em que fossem indistinguíveis. Assim a gestualidade libertadora da abstração lírica americana, com sua promessa de emancipação transcendental, se mistura a bandeiras patrióticas, a mapas estratégicos, a números e letras gráficas blocados, como os usados para pintar equipamento militar. ${ }^{145} \mathrm{O}$ incômodo é ver essa promessa libertária, subjetiva, lado a lado com a freedom imperialista de uma hegemonia militar recém-conquistada, em plena Guerra Fria, depois da bomba atômica, quando os sonhos de uma liderança americana, como uma ampliação dos direitos democráticos para o resto do planeta, soavam ilusórios. Como o próprio Morris afirma, esse sentido político, provavelmente não foi intencional. ${ }^{146}$ Mas para ele, isso não importa. O que nos interessa aqui é a capacidade do artista de esvaziar o sentido tanto de um objeto ordinário, quanto da pintura. E fazer isso, preservando as duas coisas.

Há um trecho de Leo Steinberg em que ele expressa muito bem essa ansiedade:

(...) os quadros de Jasper Johns acabaram me impressionando como uma cidade fantasma o faria - mas uma cidade fantasma de terrível familiaridade. Só restam objetos - signos feitos pela mão das pessoas e

144 MORRIS, Robert. "From a chomskian couch". Em Have I Reasons: Work and Writings. Duke University Press Books, 2008. p. 174.

145 MORRIS, Robert: "Jasper Johns: the first decade". Idem.

146 Idem, p. 227. 
que, na ausência delas, tornaram-se objetos. E Johns antecipou o seu abandono. ${ }^{147}$

O que parece ser importante para nós nos dois argumentos é o esvaziamento dos sentidos ideológicos atribuídos tanto a certas escolhas estéticas, quanto a símbolos amplamente reconhecíveis. Johns esvazia os códigos mais complexos e mais evidentes.

Essa iconografia de Johns, feita de signos legíveis, aproximará o seu trabalho daquilo que mais tarde será conhecido como pop. Mas é enganoso tomar o repertório de Johns como pop. O artista lida com elementos de uma cultura popular, como foi dito antes, ligada a obsessão do modernismo norte-americano com o folk e o "homem comum". Mais, sua iconografia vem do mundo do trabalho artesanal, a expansão do capitalismo fordista parece torná-la antiquada. Ele lida com muitos símbolos envelhecidos. Mesmo assim, sua pintura abrirá o caminho para uma geração de artistas que lida com essa iconografia saída de um repertório distante da história da arte. ${ }^{148}$

O impacto foi imediato. A geração imediatamente posterior de artistas novaiorquinos se dedicou a refazer as imagens da crescente indústria de consumo. Tal geração aparece no auge do expressionismo abstrato. Boa parte dos artistas sai daí e mantém uma admiração inquestionável pela arte americana dos anos 1940 e 1950. Também testemunham as primeiras indagações sobre certos sentidos estético-ideológicos do movimento. O discurso antirracionalista, místico, transcendentalista dessa obra, bem como a sua melancolia pós-guerra tornam-se questões. As promessas metafísicas da pintura abstrata são problematizadas por Johns, Rauschenberg e Twombly.

147 STEINBERG, Leo. “A arte contemporânea e a situação de seu público”. Em Outros Critérios. São Paulo: Cosac Naify, 2008. p. 34.

148 Em texto de 1962, Michael Fried fala em "pintores que hoje trabalham a serviço de uma iconografia popular". FRIED, Michael. "From New York Letter". Em MADOFF, S.H. (Org.) Pop Art: a critical history. Berkeley: University of California Press, 1997. p. 267. 
A geração de Warhol, que surge poucos anos depois, trabalhará com a massa de imagens da indústria cultural. Na década seguinte, eles seriam chamados de "artistas pop". No entanto, faziam o que faziam sem responder a manifestos, sem trabalhar coletivamente nem pensar que construíam uma nova vanguarda ou estilo de arte moderna.

Esses criadores desenvolvem suas linguagens isoladamente, sem um saber no que o outro trabalhava. Respondem a um clima cultural difuso, voltam-se para uma arte figurativa, de contornos gráficos e colorido estridente, saído de tintas sintéticas, com aparência artificial. O repertório desses artistas é similar. Como se imprimissem, replicam imagens de rótulos de produtos, de histórias em quadrinhos, fotografias, cartazes, anúncios, páginas de revista e stills de cinema. Assim, refazem as imagens da crescente indústria de consumo

Não era a primeira vez que artistas nos Estados Unidos se dedicavam à representação do imaginário da mercadoria, das celebridades e da imprensa. No século XIX, artistas de trompe l'oeil, como John Frederick Peto e Jefferson David Chalfant, pintam notas de dólar como grandes falsários. Na modernidade, rótulos, letreiros de lojas e vitrines foram assunto da fotografia de Walker Evans e de muitos outros. Um insuspeito Willem De Kooning pinta Marilyn Monroe em 1954, oito anos antes de Warhol trabalhar sobre a fotografia da atriz. O que é particular é o modo como esses artistas da geração pop se dedicarão a esse imaginário.

Eles representam essas imagens fortemente ancorados nas linguagens da comunicação visual de massa, da publicidade e do design. Andy Warhol repete rótulos de sopas Campbell na tela com o apuro de quem imprime um logotipo no outdoor. Roy Lichtenstein (34) procura emular com perfeição o reticulado ben-day. Faz isso sem recorrer a recursos gráficos das revistas e jornais, mas pintando a mão. Aliás, tal tratamento torna possível aproximá-lo dos divisionistas como Seurat, Signac e Cross. Os 
artistas tentam fazer pintura e escultura, objetos de contemplação, para museu e galeria, com as convenções de outros campos de produção de imagem. Como afirma Benjamin Buchloh: "Warhol está razoavelmente preparado para reconciliar as contradições que emergem do colapso da alta cultura em direção à indústria cultural e tomar parte nisso com suas técnicas e perícia de artista comercial". ${ }^{149}$ Resta saber se a conciliação é possível.

Pela primeira vez, de maneira desarticulada, um grupo de artistas realiza trabalhos de museu, a serem contemplados em uma sala silenciosa, assemelhados aos clichês de uma nova e vibrante cultura visual que brotava nos meios de comunicação de massa. Não se trata de repetir ou desenvolver as convenções da arte tradicional ou da vanguarda. Embora o diálogo exista e seja importante, esses artistas mergulham suas pinturas e esculturas em um novo regime de imagens.

A obra deles não busca a originalidade dos artistas abstratos americanos que foram os seus antecessores. Não há procura por relações formais inéditas, inusitadas, feitas de formas não referenciais brutais, gestos espontâneos a compor um espaço indescritível, difícil de ser identificado com qualquer coisa antes vista. A ideia de pop vem um tanto desse caráter de uma cultura feita de produtos comerciais, reprodutíveis e ordinários. Ela parece se misturar com a problematização que Johns faz do modernismo na pintura americana. Ele parte de materiais totalmente organizados pela racionalidade mercantil, com função, com praticidade, para mostrá-los como "finalidades sem fim", como objetos a serem contemplados.

É um período curioso. Nos anos 1940, no fim da Segunda Guerra Mundial, algumas utopias, já gastas pelos totalitarismos, pela Grande Depressão, por duas guerras 
mundiais e por promessas constantemente frustradas, fazem com que a arte procure novos caminhos para a ideia de emancipação e transcendência.

Os maiores artistas dos Estados Unidos, como Jackson Pollock, Mark Rothko, Barnett Newman, vivem essa crise e reelaboram uma resposta artística a essa experiência brutalizada e de expectativas decrescentes sobre o futuro. Boa parte deles passou de alguma maneira pelo radicalismo político. Depois de trabalhar com pinturas de cunho mais realista, muitos vão se aprofundar nas questões surrealistas da consciência e estudar a psicanálise e a psicologia junguiana e desenvolver críticas da racionalidade. No entanto, em vez de se figurarem esses conflitos, os artistas decidem pensar essas questões na organização do espaço, na disposição de cores em uma dimensão, talvez pela primeira vez, cinematográfica de pintura abstrata.

Ainda existia o horizonte bastante modernista de se livrar das amarras atávicas do passado, mas agora o caminho não é uma busca por promessas do futuro, mas um mergulho nas complexidades existenciais. Livrar-se da sufocante tradição era se livrar de formas convencionais e irrefletidas de organizar a imagem na pintura. Por isso, alguns intelectuais da época entenderam tanto a indeterminação espacial das pinturas de Pollock quanto sua gestualidade como uma catarse, uma busca de liberação vinda da fisicalidade do gesto utilizado para compor as pinturas. Em sua análise carregada, Serge Guilbaut lembra críticos como Harold Rosenberg pela associação do gesto solto na pintura com uma espécie de emancipação psíquica. ${ }^{150}$

Outros autores, como Clement Greenberg, Michael Fried, William Rubin e Irving Sandler, vão tratar da complexidade da forma, da tentativa de se pensar uma imagem não referencial, uma imagem que não afirmasse um gosto, uma noção, uma 
espacialidade previamente identificável, mas buscasse a complexidade das relações formais e colorísticas. Em ambos os casos, o sentido da liberdade formal, da novidade artística se deve não a questões externas à pintura, à temática, mas a uma busca de formulações visuais puras e radicais. Segundo Guilbaut, boa parte desses artistas passa a ver esse mergulho em formas mais subjetivas de liberação como uma alternativa ao modelo soviético de emancipação humana e suas academias de ginástica.

O modernismo se sedimenta como a linguagem do chamado "mundo livre". Mais do que isso, como a interpretação americana do que é o modernismo. Uma interpretação que se apoia nas ideias de liberdade formal, de busca por uma complexidade estrutural e pela tentativa de evitar as convenções. De qualquer modo, trata-se de um esforço altamente intelectualizado. Parece não dizer mais respeito às linhagens mais rebeldes e literárias das vanguardas, ${ }^{151}$ como o surrealismo e o dadaísmo, mas a uma linguagem que procura se renovar a partir de regras já estabelecidas desde o fim do século XIX. O ar maldito da arte moderna parece ter ficado para trás. Embora o trabalho desafie o empobrecimento de um gosto médio, faz isso por meio da complexidade estrutural. As questões culturais e temáticas mais imediatas são menos importantes.

Na década de 1950, os artistas abstratos foram decisivos no trabalho de artistas como Warhol, Oldenburg, Johns e Rauschenberg, mas o caminho deles é bastante diferente. A arte como lugar da experiência distinta, complexa, capaz de superar a experiência ordinária é problematizada simultaneamente em vários lugares do mundo.

\section{Sobre a pop}

Preocupados com um novo papel para a vanguarda e sua intervenção na indústria, um grupo de artistas, arquitetos e intelectuais britânicos, o Independent Group,

151 Em 1951, o pintor abstrato Robert Motherwell publica a compilação Dada painters and poets. O livro é muito influente no meio de arte nova-iorquino. 
reflete sobre a produção da indústria cultural com interesse genuíno. Eles são os primeiros que se dedicam ao estudo da pop como arte; sem condescendência ou menosprezo. Formado em 1951, com integrantes como o crítico Lawrence Alloway, os arquitetos Peter e Alison Smithson e os artistas Eduardo Paolozzi e Richard Hamilton, o grupo se interessa pela nova iconografia dos quadrinhos, dos letreiros, das revistas, do design italiano e do cinema americano.

A Inglaterra do pós-guerra era um país curioso. Apesar de industrializado, acabara de perder o protagonismo imperial para os Estados Unidos; sofria com a guerra, mas mantinha muitos traços aristocráticos. Pior: sobreviviam aspectos profundamente conservadores e reacionários em uma sociedade que gostava de se gabar como uma das democracias mais antigas do mundo. Lá, a homossexualidade foi crime até 1967. A censura oficial a teatros existiu até 1966 e o repertório das rádios era controlado pelo Ministério de Comunicações anos depois da Segunda Guerra. A legislação dos anos 1950, no entanto, se contrapunha à realidade inglesa: os jovens escutavam rock e se deleitavam com os produtos e o estilo de vida dos seus contemporâneos americanos. Suas identidades se formaram na aspiração de um estilo de vida que se não existia em suas ruas, era projetado nas telas de cinema e transmitido não pelas rádios inglesas, mas pela Voice of America.

A cultura de massa para eles surge como uma linguagem libertadora, não aristocrática, na qual os salamaleques da tradição não tinham vez. Nesse sentido, têm muito do antitradicionalismo modernista. Os artistas e intelectuais do Independent Group concebem os produtos da indústria cultural como um mundo novo. Um mundo jovem, de relações mais diretas, que pensa - de maneira desabusada - questões tradicionais da história da arte europeia. Aliás, um mundo de fortes apelos sexuais e construção de novos comportamentos. Essa produção, que eles chamam de pop, é tratada como uma antevisão 
de um futuro vanguardista. Para eles, a pop não é a produção deles, mas da indústria, onde pretendem intervir.

O termo "pop" já existia desde o século XIX, mas era uma classificação arbitrária. Segundo o crítico de rock Jon Savage, o seu primeiro registro aparece para identificar a música popular, como sinônimo de plebeu. ${ }^{152}$ A mudança se dá mais de meio século depois, quando "pop" começa a aparecer nas revistas inglesas de música, como a Melody Maker, nos anos de 1940. Entre os anos 1950 e 1960, a palavra ganha uso corrente.

O Independent Group será o primeiro grupo de artistas e intelectuais a tratar a ideia de pop com seriedade nas artes plásticas. Em 1947, Eduardo Paolozzi estampa a palavra "pop" em sua colagem I Was a Rich Man's Plaything (163). ${ }^{153}$ Diante do rosto da pinup sorrindo de modo sedutor para nós, a palavra é tanto a onomatopeia de tiro, o ruído de surpresa diante de tamanho fascínio sexual, quanto a marca de um novo tempo. O mundo passa a ser representado por um acúmulo de figuras ruidosas, formas saídas de imagens reprodutíveis e de comunicação imediata.

Quando define pop art, ${ }^{154}$ o Independent Group traça menos um partido estético ou uma poética a ser perseguida, do que anuncia, deslumbrado, um novo imaginário que parecia se formar a partir das imagens de Hollywood, dos quadrinhos, da televisão, das

152 SAVAGE, Jon. "The Simple Things You See Are All Complicated". Em KUREISHI, H; SAVAGE, J. (Orgs.). The Faber Book of Pop. Londres: Faber \& Faber, 1995. p. xxiv.

153 Algo como: "Eu era um brinquedo de um ricaço".

154 O crítico inglês Lawrence Alloway usa o termo pela primeira vez em 1954. Segundo Lynne Cooke: "Alloway cunha o termo "pop" inicialmente para referir-se ao largo interesse na cultura popular expresso pelos membros do Independent Group em suas discussões, palestras e outras atividades. [...] Em 1962, Alloway se muda para os Estados Unidos, onde rapidamente se torna um curador influente de exposições pioneiras dedicadas ao trabalho dos participantes principais no que emergia sob diversas rubricas antes de finalmente se tornar conhecido como Pop Art". "From the Independent Group: British and American Pop Art, a Palimpcestous Legacy" [1990]. Em S. H. Madoff. (Org.) Pop Art: A Critical History. Berkeley: University of California Press, 1997. p. 390. Em 1963, Jason Reichardt define o que significava pop arte para Lawrence Alloway em 1954: segundo, Reichardt o crítico inglês falava de "propagandas em revistas, cartazes nas portas dos cinemas, panfletos, toda a literatura descartável comunicando a mesma mensagem". "Pop Art and After". Em S. H. Madoff. (Org.), op. cit., p. 14. 
revistas pulp, dos automóveis e da música radiofônica. Era a imagem de um futuro que chegara. Sintomaticamente, a exposição-manifesto do grupo, realizada no Institute of Contemporary Art de Londres (ICA) em 1956, chamava-se This is Tomorrow (164). ${ }^{155}$

Em uma carta de 1957 para seus colegas Alison e Peter Smithson do Independent Group, Richard Hamilton define a pop art como:

Popular (concebida para um público massa). Transitória (soluções a curto prazo). Dispensável (fácil de esquecer). De baixo custo. Produzida em massa. Jovem (destinada à juventude). Espirituosa. Sexy. Artificiosa. Glamourosa. Big Business. ${ }^{156}$

De fato, era tudo muito novo, veloz e fascinante. A pop aqui era uma produção cultural, não uma vanguarda ou um estilo de arte.

A pop tem algumas propriedades distintas da produção cultural associada, por exemplo, ao kitsch. Ela é necessariamente industrial e distante das linguagens tradicionais do artesanato. O kitsch almeja o grande gosto da tradição, por isso, realiza versões barateadas de formas narrativas e figurativas reconhecíveis, absolutamente convencionais. O “criador" exacerba as características estilísticas do que ele faz para que o objeto seja inquestionavelmente "artístico" ${ }^{157}$ O kitsch parte de características de um gosto estabelecido. Quer parecer arte.

155 Nome da segunda grande exposição do Independent Group. Aconteceu em 1956, na Whitechappel Gallery, em Londres.

156 HAMILTON, Richard. "Letter to Peter and Alison Smithson” [1957]. Em Mark Francis; Hal Foster. (Orgs.) Pop (Themes and Movements). Londres: Phaidon, 2005. p. 198.

157 Em 1939, o crítico Clement Greenberg publica na Partisan Review o ensaio "Vanguarda e Kitsch". Nele, o autor contrapõe uma produção que desafia e problematiza as noções convencionais de arte, a vanguarda, e outra que reafirma um sentido convencional e imutável da arte e da cultura: o kitsch. O kitsch definiria um conjunto de artefatos culturais que procurariam parecer o que não eram: grande arte. Para se passar por seu modelo mais sério, buscava as semelhanças mais conservadoras possível. O kitsch simulava o que um senso comum embrutecido entendia pelas emoções da arte e as suas categorias mais regressivas. Era uma representação edulcorada, irrefletida e de mau gosto das formas mais tradicionais de sensibilidade artística. $\mathrm{O}$ kitsch era a repetição de convenções irritantemente compreensíveis do que seria uma obra de arte. Como Greenberg explica: "O kitsch, usando como matéria-prima os simulacros 
Em 1945, Theodor Adorno usou o kitsch como um exemplo da cultura afirmativa em um fragmento da sua Minima Moralia. No trecho, o filósofo dá uma definição divertida dos anões de jardim, globos de vidro com paisagens, melodramas e canções de rádio. Chama-os de "coisas horripilantes, acumuladas pela casa, pela sua semelhança com obras de arte" ${ }^{158}$ O interessante é que essa semelhança não é necessariamente a face da pop. Embora o pop possa ser kitsch, ele não o é necessariamente; responde mais a critérios industriais pragmáticos do que a um bom gosto nostálgico.

Sendo assim, a pop parece ser um campo com alguma autonomia em relação aos meios de validação tradicionais da criação visual. Assim, embora possa se apoiar em uma figuração kitsch, que retoma um gosto simplificado da arte, a imagem pop não presta contas ao meio de arte.

O que vai interessar ao Independent Group é essa nova relação com a linguagem cultural industrial que estaria nos filmes, na literatura barata, nos cartazes, nos eletrodomésticos, nos móveis fabricados industrialmente, nas revistas, nas fotografias e, sobretudo, na televisão. Os produtos que interessam ao Independent Group são feitos não para ser mostrados em galerias, mas em meio ao frenesi do consumo. Mesmo assim, os artistas do grupo exibem esses badulaques junto a trabalhos de arte, espaços arquitetônicos, imagens de toda a ordem como se um fosse continuidade do outro; quase como uma inversão dos princípios construtivos da Bauhaus, onde os artistas agora sairiam dos ateliês para interferir e recriar a produção industrial. Aqui, para recriar uma arte do

\footnotetext{
degradados e academicizados da cultura genuína, acolhe e cultiva esta insensibilidade, que é fonte de seus lucros. O kitsch é mecânico e opera por fórmulas. $\mathrm{O}$ kitsch é experiência vicária e sensações falsas. $\mathrm{O}$ kitsch muda de acordo com o estilo, mas permanece sempre o mesmo. O kitsch finge não exigir nada de seus clientes a não ser dinheiro - nem mesmo o seu tempo". GREENBERG, Clement. "Vanguarda e kitsch". Em Arte e cultura. São Paulo: Ática, 1996. p. 29.

158 ADORNO, Theodor. Fragmento 145: "Figura de arte". Em Minima Moralia: reflexões a partir da vida lesada. Trad. Gabriel Cohn. Rio de Janeiro: Beco do Azougue, 2008. p. 223.
} 
futuro, artistas como Eduardo Paolozzi e Richard Hamilton começam a tomar os elementos sedutores que a indústria lhes oferece. ${ }^{159}$ Assim, não é a arte que vai à indústria, para que essa aprenda com os seus procedimentos racionais, mas o contrário. A arte passa a tentar aprender a falar a linguagem da indústria cultural.

No caso dos artistas ingleses, essa relação não se dá de maneira tão direta. Eles jamais aderiram ao modelo de produção e relação com as imagens para consumo de massa como os americanos. Essa identidade absoluta entre a obra e o referente apropriado não existe na produção dos artistas do Independent Group.

O que importa notar aqui é um esforço de desierarquização entre a produção culta e um regime industrial de produção. Os membros do Independent Group aproximam a produção gráfica de massa e a arte de museu. Procuram esse diálogo como uma possibilidade de intervir no mundo e tornar a arte mais presente no debate público. Identificam figuras de robôs com peças de Shakespeare ${ }^{160}$ e displays de musas do cinema com quaisquer outras figuras da tradição. Parecem trabalhar com a continuidade entre alta cultura e cultura de massa. A cultura de massa seria colocada em debate com as questões da tradição artística e das vanguardas e, segundo os membros do Independent Group, teria muito o que ensinar. Não por acaso, trata-se de uma produção otimista. Nesses primeiros anos da década de 1950, há a promessa de um mundo novo, resultado da mudança dos hábitos culturais, sexuais e familiares. O Independent Group encarna o desejo de fazer a arte funcionar dentro das linguagens reprodutíveis. Isso parece ligeiramente distinto do

159 Segundo Alfred Baar, a Bauhaus "preencheu a lacuna entre o artista e o sistema industrial, rompendo uma hierarquia que separava as 'belas-artes' das artes 'aplicadas"”; em pedagogia, "estabeleceu a diferença entre o que pode ser ensinado (técnica) e o que não pode (invenção criativa), tendo reunido mais artistas de talento do que nenhuma outra escola de arte do nosso tempo o fizera"; em arte, "desenvolveu uma forma de beleza nova e moderna". Citado em RICKEY, George. Construtivismo: origem e evolução. São Paulo: Cosac e Naify, 2002. p. 67.

160 CROW, Thomas. The long march of pop: art, music and design 1930-1995. New Haven: Yale University Press, 2014. p. 86-8. 
que acontece na pop americana, pois, aqui, não se trata de se estabelecer um diálogo entre a produção artística tradicional e as linguagens de consumo. Trata-se do momento em que a arte de museu se dedica a replicar as imagens de consumo, em refazer sua imagem. A pop torna-se outra coisa quando retorna ao seu berço: os Estados Unidos. ${ }^{161}$

3.

No final dos anos 1950, artistas americanos, também se interessam pelas imagens produzidas em massa e tensionam a sofisticada pintura gestual americana com uma iconografia comum, facilmente identificável. Influenciados por Jasper Johns e Robert Rauschenberg, todos se dedicam a reproduzir a iconografia da cultura de consumo. Artistas como Claes Oldenburg, Robert Indiana, Roy Lichtenstein, Andy Warhol, Ed Ruscha, Billy Al Bengston e James Rosenquist imitam cartazes de cinema, histórias em quadrinhos, imagens das vitrines das lojas, logotipos de marcas. Não se trata apenas de coletar uma iconografia da cultura de massa, mas de copiá-la. A obra de arte não tenta manipular os signos, faz com que a obra estabeleça uma identidade total com eles.

O impacto foi imediato. Mesmo críticos entusiasmados com a produção de Jasper Johns, Robert Rauschenberg e Jim Dine, como Barbara Rose, se sentiram desafiados. Por ocasião da exposição Six painters and the object, no Guggenheim, curada por Lawrence Alloway, Rose publicou sobre Warhol ou Lichtenstein: “Eu considero essas imagens ofensivas; estou aborrecida por ter que olhar em uma galeria o que sou forçada a ver no supermercado. Eu vou à galeria para fugir do supermercado, não para repetir a

161 "A Arte Pop é um fenômeno americano que tem como ponto de partida o clichê da grande, indômita e bisonha América que se tornou corrente quando o expressionismo abstrato triunfou internacionalmente (...) Mais importante: o pop é um produto híbrido resultante de duas décadas dominadas pela abstração, e como tal, herdeira de uma tradição mais abstrata do que figurativa." LIPPARD, Lucy. A Arte Pop. Lisboa: Verbo, 1973. p. 9. 
experiência". ${ }^{162}$ Ultrajada, a autora não põe em dúvida que aquilo é arte, só parece certa de que não é bom e não é uma boa escolha para um museu. ${ }^{163} \mathrm{O}$ incômodo se manifesta com a possibilidade de o museu, a instituição mais digna e importante do mundo da arte, endossar a cultura de consumo. Ou seja, do espaço da reflexão estar sendo tomado por outros regimes de imagem.

Em uma correspondência enviada de Los Angeles para a revista Art International, em 1962, Jules Langsner lamenta o trabalho de artistas que replicavam imagens do cotidiano em telas de larga escala. Langsner era um crítico californiano que apoiou o trabalho de artistas como Philip Guston e Franz Kline. Embora o seu texto demonstre desconfiança profunda da pop, ele é bastante educado. Parece preocupado em apontar um novo espaço criativo que essas obras anunciam. Ele comenta a exposição New Paintings of Common objects, no Pasadena Museum of Art, que reunia a nova figuração na pintura americana, associando-a a um acontecimento transatlântico que se comunicava tanto com a nova objetividade francesa como com sua equivalente alemã.

No artigo, ${ }^{164}$ Langsner utiliza o termo "pop", mas não para falar de um novo estilo. Para ele, pop é uma cultura comercial, baseada em uma produção feita para ser serial, fruto da indústria de comunicação visual veloz e banal. Provavelmente, ele se vale das definições britânicas, de Lawrence Alloway, dos anos 1950. Os artistas não são apresentados como parte de um movimento e nem de um estilo. Não por acaso, o crítico saca vários termos para falar do que eles fazem: New social realism, Common object painting e até o trocadilho de Andy Warhol, Commonism.

162 Originalmente publicada na revista Art International 8, n. 5, de 25 de maio de 1963. ROSE, Barbara. "Pop Art at the Guggenheim". Em MADOFF, Steve Henry. Pop Art: critical history. Berkeley: University of Californa Press, 1997. p. 84.

163 Idem.

164 LANGSNER, Jules. "From Los Angeles Letter”. Em MADOFF, Steve Henry. Pop Art: critical history. Berkeley: University of Californa Press, 1997. p. 33-4). Originalmente publicado na revista Art International, em setembro de 1962. 
Ele diferencia artistas que partem dos objetos para realizar uma pintura figurativa mais convencional, dos que se atêm a copiar com maior precisão as imagens que lhes servem de motivo, imitando, a partir das técnicas de pintura, como a pincelada e o estêncil, a superfície e os modos de trabalhar da gráfica. No primeiro grupo, inclui Philip Hefferton, Robert Dowd e Wayne Thiebaud; no segundo, sobretudo Andy Warhol e Roy Lichtenstein.

Os trabalhos do último grupo o incomodam. Eles parecem similares demais às imagens das quais partem. Para ele, havia pouco trabalho artístico, pouca intervenção, pouca elaboração. Para um intelectual que sempre prezou a originalidade formal, aquilo era só cópia. Assim, para Langsner, como para vários outros críticos da época, era difícil encontrar alguma elaboração para além de um uso de uma imagem não artística na obra.

Não haveria significado acrescentado às imagens retiradas de outro lugar. As imagens parecem pouco artísticas e nada oferecem a quem se dispõe a contemplá-las. Embora reconheça aquilo como uma empreitada ousada, acha que o "impulso criador" daqueles trabalhos é "insuficientemente estético". ${ }^{165}$

Como parte dos que se entusiasmam ou rejeitam aquela produção nos seus primeiros dias, Langsner vê aquilo mais como uma empreitada vanguardista, a questionar os limites da definição de arte e sua relação tanto com o avanço nada reflexivo da forma mercadoria, quanto com a diluição da contemplação artística nos deleites velozes e simplórios da indústria cultural. Será comum a afirmação de que a obra de Lichtenstein, Warhol, Indiana e, até, Ruscha, interessaria mais aos departamentos universitários 
interessados na definição conceitual dos objetos e no alargamento e na crítica do conceito de obra de arte do que a quem procurasse uma genuína e original elaboração artística. ${ }^{166}$

Mas de forma geral, o que está expresso nesse texto é o despontar de um novo fenômeno estético nos Estados Unidos. São artistas menos interessados nas questões do expressionismo abstrato e mais ligados a um imaginário cultural juvenil, veloz, simplificado, de linguagem limpa, moderna e de comunicação direta. Vários textos no começo dos anos 1960 indicam esse clima cultural que toma distância da complexidade da pintura abstrata americana e mergulha, por alguma razão, em um mar de banalidade.

Nas discussões, debate-se o interesse de artistas em um novo efeito estético, em uma relação menos reticente com a imagem; levantam-se discussões sobre a reprodução, o anonimato, a autoria e a cultura de massa. O novo Leviatã produtor das imagens invadira o mais reflexivo dos meios. ${ }^{167}$ Entre 1962 e 1963, em meio a um rico debate, a produção desses artistas é nomeada pop art. O termo havia sido criado na Inglaterra, em 1954, com outros propósitos, pelo crítico Lawrence Alloway, e agora nomeava uma novidade na história da arte. ${ }^{168}$

Os artistas da pop americana procuram atribuir ao objeto único, a pintura, por exemplo, a aparência da imagem reprodutível. O trabalho perderia a sua feição artística, igualando a mercadoria específica e rara da arte com a mercadoria produzida em série. Assim, o que está em exposição se assemelharia ao produto das gôndolas. Os artistas

166 “(...) the enterprise may have significance, but not as painting or sculpture”. Idem, p.34. 167 Um bom sumário da discussão dos anos 1960 está em MADOFF, Steve Henry. Pop Art: critical history. Berkeley: University of California Press, 1997. Recomendo como uma síntese desses primeiros debates o texto do galerista Sidney Janis. JANIS, Sidney. On the theme of exhibitions. p. 39-40); de John Coplans. COPLANS, John. The new paintings of common objects. p. 43-46); e de Barbara Rose. ROSE, Barbara. Dada, then and now. p. 57-64.

168 Segundo Jason Reichardt, a categoria se estabelece com a ida de Lawrence Alloway para Nova York em 1962. REICHARDT, Jason. "Pop art and after". Em MADOFF, S.H. (Org.). Pop Art: A critical history. Berkeley: University of California Press, 1997. p. 14. Tudo indica que foi o próprio Alloway que batizou essa série de manifestações de vanguarda, ou neovanguarda, com o nome que ele utilizara para falar da produção visual que não respondia a questões nem da arte moderna e nem da tradição; e era vista nas vitrines, nas bancas de jornal, nos cartazes, nas lojas, não nos museus e galerias. 
fazem réplicas ampliadas ou reduzidas de símbolos amplamente reconhecíveis dos moradores das cidades americanas daquela época, com um tratamento tal, que muitas vezes a obra de arte e a imagem que a inspirou se tornam quase indistintas.

Aliás, Andy Warhol, em pinturas relativamente grandes feitas em 1961, parece reforçar a imagem gráfica dos trabalhos. Quer que elas soem mais banais, menos artísticas, menos detalhadas que os anúncios de jornal. Telephone (1961) e Typewriter (1961) (27-28) foram feitos a partir de anúncios da primeira metade do século XX. ${ }^{169}$ Nas pinturas, os matizes de cinza e os modelados dos objetos são atenuados. O artista força o contraste entre preto e branco, achata os objetos e os pinta como grandes carimbos. A arte se mistura de uma maneira mais ou menos próxima da inflação de imagens que começa a tomar as metrópoles dessa época.

Embora a pop se afaste da abstração americana dos anos 1940, ela aprende procedimentos de escala e de uma dimensão sangrada e espetacular da obra com os artistas abstratos. ${ }^{170}$ As obras de Rosenquist e Warhol desejam a dimensão do outdoor (Billboard), como os trabalhos de Pollock. No calor da hora, Lucy Lippard afirmou, provocando os críticos mais antigos, que: "A arte pop está mais relacionada com o postpainterly abstraction de Ellsworth Kelly e Kenneth Noland do que com o realismo contemporâneo". ${ }^{171}$

169 Telephone parte de uma ilustração na propaganda da Bell System Telephone Service, de 1928, e Typewritter imita uma imagem de divulgação da Royal Typewritter de 1936. As imagens podem ser comparadas em GOLDS9

MITH, Kenneth (Org.) Andy Warhol Giant Size. Londres/Nova York, 2006. p. 92-3.

170 Em uma perspectiva muito diferente, ligada às posições de classe dos artistas, T.J. Clark permite uma aproximação entre a abstração americana e a pop ao qualificar a primeira como espetacular e vulgar.

CLARK, T.J. "Em defesa do expressionismo abstrato". Em Modernismos: ensaios sobre política, história e teoria da arte. São Paulo: Cosac Naify, 2017.

171 LIPPARD, Lucy. A Arte Pop. Lisboa: Verbo, 1973. p. 10. 
As pinturas de Robert Indiana, como A divorced man has never been the president (1961) (29-30)serão associadas ao imaginário das placas de sinalização, aos painéis de jogo de fliperama. ${ }^{172} \mathrm{O}$ artista, no entanto, chegou a esses efeitos a partir do estudo das formas da abstração hard-edge, em seu aprendizado com pintores abstratos contemporâneos como Agnes Martin e, sobretudo, Ellsworth Kelly. ${ }^{173}$ Isso ele identificará com um repertório da iconografia popular, típico da Americana, como mencionado por Alfred Baar em 1961. ${ }^{174}$

Em vez de distinguir os procedimentos da vanguarda da sinalização mambembe, Indiana parece igualar as coisas, à maneira de Johns. Embora carregasse nesses esquemas rígidos, de cores gráficas, frases irônicas, a pintura era muito próxima da comunicação visual. $\mathrm{O}$ artista estabelece um jogo de espelhos entre a formalização da pintura abstrata, a iconografia popular e os produtos de comunicação de massa, que nos convidam a pensar sua indistinção.

Da mesma forma, as telas que Roy Lichtenstein desenvolve a partir de 1961 tornam-se cada vez mais próximas das vinhetas que ele retira de figurinhas de chiclete, ilustrações de livros infantis e histórias em quadrinhos (34). Mas ao mesmo tempo em que suas imagens são escolhidas de fontes gráficas "não artísticas", Lichtenstein pinta, enquadra, e amplia imagens que nos rememoram as convenções mais tradicionais da história da arte europeia. Ao transpor os quadrinhos para a tela grande, ele busca semelhanças dos desenhos das histórias em quadrinhos com modelos de composição e gêneros da história da arte (31-33).

172 LIPPARD, Lucy. “O 'Pop' de Nova York”. Em A Arte Pop. Lisboa: Verbo, 1973. 173 Idem, p. 133.

174 CROW, Thomas. The long march of pop: art, music and design 1930-1995. New Haven: Yale University Press, 2014. p.139. 
Ainda em 1962, Donald Judd fala do ultraje ${ }^{175}$ causado pelas pinturas de Lichtenstein. Comentando a tela $O$ beijo (1962), ele não responde aos argumentos da controvérsia, mas se mostra interessado e intrigado pela capacidade de Lichtenstein articular elementos formais mecânicos, absolutamente banais, a uma composição tradicional, que Judd chama de obsoleta. Poderíamos dar um sem número de exemplos, mas o que importa ao raciocínio é o diálogo estabelecido entre os meios de comunicação de massa e as linguagens próprias da arte de exposição, assim como uma imagem da arte, que começa a despontar nos primeiros anos da década de 1960, em que essa obra pouco se diferencia de objetos ou imagens ordinárias, banais. ${ }^{176}$

Os dois artistas parecem brincar com um jogo de espelhos em que convenções da história da arte são encontradas de algum modo em um repertório totalmente alheio a essa narrativa. Ambos lidam com esses objetos estranhos ao mundo da arte. A radicalidade do trabalho de Andy Warhol é que, aos poucos ele parece inverter a equação. Nos seus trabalhos, sobretudo a partir de 1962, é a arte que tenta se diluir no imaginário banal, sem deixar nenhum resquício do que já foi.

4.

Não por acaso, pensadores de trajetórias e orientações teóricas tão distintas como Arthur C. Danto ${ }^{177}$ e Andreas Huyssen ${ }^{178}$ vão abordar o trabalho de Warhol como um desafio para o meio de arte. Mais do que como uma fabulação visual, tratam o trabalho como um questionamento meta-artístico, do sentido cognitivo ou social da obra de arte

\footnotetext{
175 A reação negativa deve ter sido significativa. Dois anos depois, quando a carreira do artista estava consolidada, uma matéria na revista Life de 31 de janeiro de 1964 se perguntava se Lichtenstein seria o pior pintor dos Estados Unidos.

${ }^{176}$ A questão não é nova. O estudo mais antigo que a pesquisa encontrou sobre o assunto é o livro de FINCH, Christopher. Pop art: object and image. Londres: Studio Vista, 1968.

${ }^{177}$ DANTO, Arthur C. A transfiguração do lugar comum. São Paulo: Cosac Naify, 2006.

${ }^{178}$ HUYSSEN, Andréas. "A política cultural da Pop”. Em Memórias do Modernismo. Rio de Janeiro: Editora da UFRJ, 1996.
} 
na sociedade do capitalismo avançado. Em uma perspectiva mais lógica ou em outra mais crítica do capitalismo, ambos tentam entender o novo sentido que a obra de Warhol traz à arte. Melhor, qual seria o desafio formulado por Warhol, seja na inserção da obra de arte no processo de valorização do capital, seja nas formas de acomodação racional dos objetos às convenções intelectuais?

Danto, ao analisar as Brillo Boxes (1964) aponta um caráter aporético ${ }^{179}$ de provocação na obra. O trabalho de Warhol surge menos como uma formulação particular $^{180}$ e mais como um questionamento estético e conceitual, ao que o pensador definiu como o "mundo da arte". 181

A análise de Huyssen parte da assimilação alemã da pop, que analisaremos no próximo capítulo. Como a Danto, interessa a ele o caráter fronteiriço do trabalho de Warhol: entre arte e não arte. Nisso, ele vê uma espécie de política cultural, que mais do que criar situações específicas em cada obra, pretende mostrar, assim como Jean Baudrillard, ${ }^{182}$ uma reificação de todas as coisas. A obra de arte aqui afirma perigosamente sua condição mercantil. Entrega o jogo, e como numa crítica institucional,

\footnotetext{
${ }^{179}$ SILVEIRA, Cristiane. "O mundo e os mundos da arte de Arthur C. Danto: uma teoria filosófica em dois tempos". Revista ARS, v. 12, n. 23, São Paulo, jan./jun. 2014.

${ }^{180}$ É importante enfatizar que no caso de Danto, a sua análise se modifica. Em seu livro dedicado à obra de Warhol, ele vê nas caixas de Brillo e Kellogs não só um desafio ao mundo da arte, ao modo ready made. Embora insista na ideia de um jogo com o mundo da arte entre o original e o imitado, ele também se aprofunda no interesse genuíno do artista pelos objetos. Warhol registraria aí um modo de beleza que é sempre o mesmo; um elogio da prosperidade democrática da sociedade americana do pós-guerra. Em DANTO, Arthur C. Andy Warhol. São Paulo: Cosac Naify, 2012. p. 85-6.

${ }^{181}$ DANTO, Arthur C. "The Art World Revisited: Comedies of Similarity". Em Beyond the Brillo Box: the visual arts in post-Historical Perspective. Nova York: Farrar, Strauss \& Giroux, 1992. No artigo, o filósofo leva adiante a resposta para duas questões nas quais ele trabalhava desde os anos 1970: "O que torna possível que algo como a Brillo Box fosse classificada como uma obra de arte?" "Qual a razão de outras caixas idênticas no supermercado não serem consideradas como tal". A sua resposta se baseia largamente no conceito de "mundo da arte". A Brillo Box de Warhol é arte por responder a um determinado contexto semântico da história da arte e interrogar as teorias da arte e dos artistas. Como melhor explica Cristiane Silveira em seu artigo sobre as mudanças de significado do conceito de "mundo da arte" em Danto, a Brillo Box funciona como uma aporia dessa inteligência. Em SILVEIRA, Cristiane. "O mundo e os mundos da arte de Arthur C. Danto: uma teoria filosófica em dois tempos". Revista ARS v. 12, n. 23, São Paulo, jan./jun. 2014.

${ }^{182}$ BAUDRILLARD, Jean. "Pop: arte de consumo" (publicado originalmente em 1970). Em A Sociedade de Consumo. Lisboa: Edições 70, 2007.
} 
diz a que veio. A arte estaria atada incontornavelmente a sua condição mercantil. ${ }^{183}$ Não pretendo me deter em nenhuma das formulações. ${ }^{184}$ Mais importante é mostrar como o caráter de antiarte da pop foi significativo no debate crítico.

No entanto, pretendo seguir outro caminho a partir da trajetória de Warhol e tentar entender como ele elaborou a imagem reprodutível na obra de arte. A confusão entre sua obra e outros artefatos visuais do mundo parece insuficiente para pensar que tipo de operação estética acontece aí.

Ele não parece buscar uma cópia perfeita dos objetos, mesmo quando pinta as sopas Campbell ou replica em madeira as caixas de sabão em pó Brillo. Mesmo porque, ele pintou poucas vezes os objetos. Interessava-lhe a reprodução das imagens. Imagens saídas de outras imagens que ao fim se desprenderam do seu referente.

Talvez por isso, abordar Warhol como um artista dedicado a problematizar e inverter as hierarquias da arte culta e da indústria cultural parece pouco. Não são os artefatos da cultura de massa que ele mostra em seus trabalhos; são esses artefatos codificados por um novo sistema de signos.

Embora seja verdadeira e poderosa a ideia de Baudrillard ${ }^{185}$ de que o que está figurado nos trabalhos de Warhol não é exatamente o referente, mas seu sucedâneo em imagem, seu sucedâneo fetichista, o artista faz algum comentário sobre o que ele pinta,

\footnotetext{
${ }^{183}$ No texto de Huyssen, ele interpreta críticos que pensam isso como crítica à sociedade de consumo, críticos que pensam isso como rendição e outros, ainda que pensam como uma intervenção na vida cotidiana, tal os situacionistas e o Grupo Fluxus. HUYSSEN, Andréas. "A política cultural da Pop". Em Memórias do Modernismo. Rio de Janeiro: Editora da UFRJ, 1996.

${ }^{184}$ Em minha dissertação de mestrado, tive a oportunidade de trabalhar essas análises: MESQUITA, Tiago. Através do espelho: A constituição da pintura inicial de Andy Warhol (1956-1968). Dissertação de Mestrado apresentada ao Departamento de Filosofia da Faculdade de Filosofia, Letras e Ciências Humanas da Universidade de São Paulo (FFLCH-USP), São Paulo, 2009.

${ }^{185}$ BAUDRILLARD, Jean. "Pop: arte de consumo" (publicado originalmente em 1970). Em A Sociedade de Consumo. Lisboa: Edições 70, 2007. p. 126.
} 
filma ou grava. Mais que isso, faz esse comentário ao produzir filmes que mostram o mesmo objeto à exaustão e quando faz com que a mesma imagem se degenere em sombra.

Warhol faz pinturas a partir de fotos capturadas por ele, realiza filmes, mostra as suas fotografias e faz gravações em áudio. Não me parece que essa busca por novas imagens seja movida apenas por um apetite pela construção de simulacros turvos, que demonstrem a falência da representação nem apenas por uma provocação dada a mover os limites da arte.

Por isso, outras vertentes da interpretação da obra de Warhol reforçam a importância do significado simbólico das imagens que o artista utiliza. ${ }^{186}$ Ao levar essas imagens às galerias, ele parecia comunicar algo possível, a partir dessa relação indireta com o mundo. O tema, seja lá como ele seja formalizado, ganha importância. O artista escolheria as imagens a serem produzidas, repetidas e reproduzidas nas telas para formular recados e juízos sobre episódios privados e públicos. Aliás, o modo de formalizar também passa a se relacionar com essa maneira de pensar.

Muitas vezes, a interpretação busca nexos entre os trabalhos do artista e sua biografia. $\mathrm{O}$ artista construiria um diálogo com outros criadores que lhe interessariam, como escritores, cineastas, músicos, dançarinos e pintores. ${ }^{187}$ Warhol pensa sua técnica, seus temas, o sentido de cada obra em particular como um esforço intelectual, uma tentativa de seu trabalho dar conta de problemas propostos por outros campos da cultura. Esses campos também envolvem a tentativa de dar forma digna e grandiosa a manifestações sociais de importância para ele.

\footnotetext{
${ }^{186}$ Entre os autores trabalhados aqui, podemos mencionar Thomas Crow, James Curley, Douglas Crimp e Jeniffer Doyle.

${ }^{187}$ WOLF, Reva. Andy Warhol: Poetry and Gossip in the 1960s. Chicago: University of Chicago, 1997.
} 
Douglas Crimp vê a forma de seus filmes como o lugar em que os personagens do universo marginal da cultura gay masculina surgem aos olhos de quem não esteve lá. ${ }^{188}$ Mas esses símbolos também são interpretados como respostas diretas a situações históricas dos Estados Unidos a partir de sugestões alegóricas. ${ }^{189}$

Esses símbolos não seguiram um caminho natural, pois envolvem o diálogo de Warhol com os seus afazeres, com a visualidade pop fora do mundo da arte e com uma atração trágica do artista pelo sucesso. De maneiras às vezes mais lineares, às vezes menos, tais significados se fazem e se desfazem na obra de Warhol. Cabe descrever trechos da sua trajetória.

Logo que resolveu se dedicar à pintura, Andy Warhol estava certo que precisava se reinventar como artista. Ele passava das artes comerciais para a chamada “arte séria”. Embora não considerasse uma necessariamente melhor que a outra, ${ }^{190}$ não lhe parecia adequado misturar os campos de atuação. Aliás, seus colegas de escritório de design não entendiam a razão para Warhol migrar para outro ramo. Como Thomas Crow afirma, ele construíra uma reputação invejável como artista comercial, ${ }^{191}$ e o que vinha para ele nas artes plásticas era nebuloso. De qualquer modo, era importante forjar uma nova identidade estética.

Por isso, era comum o artista esconder dos colecionadores os desenhos feitos durante o período em que ele foi designer em tempo integral. Warhol tinha a impressão,

${ }^{188}$ CRIMP, Douglas. Our Kind of Movie: The Films of Andy Warhol. Cambridge, MA: MIT Press, 2012; DOYLE, Jennifer; FLATLEY, Jonathan; MUÑOZ, José Esteban (Orgs.) Pop Out: Queer Warhol. Durham/Chappel Hill (NC): Duke University Press, 1996. Esta coletânea de artigos explora bem a interlocução de alguns dos símbolos explorados por Warhol com a nascente cultura gay nova-iorquina. ${ }^{189}$ CROW, Thomas. Saturday night disasters: trace and reference in early Warhol. Em MICHELSON, Anette. (Org.) Andy Warhol (October Files). Cambridge: MIT Press, 2001.

${ }^{190}$ Até aí ele considerava uma de suas grandes influências o pintor e ilustrador Ben Shahn, que obteve maior sucesso como ilustrador do que como artista de museu. O debate sobre o estatuto da arte é extensamente frutífero no capítulo 7 do livro CROW, Thomas. The long march of pop: art, music and design 1930-1995. New Haven: Yale University Press, 2015. Nele, Crow enumera os dilemas de Warhol e James Rosenquist no trabalho publicitário.

${ }^{191}$ Idem, p. 167. 
muito acertada, de que os galeristas, artistas e críticos que visitavam seu ateliê tenderiam a desvalorizar o que ele tentava criar. Para eles, soaria como uma continuação de sua lida do dia a dia. Embora mais de um autor observe a mútua influência entre o trabalho gráfico e o feito para as paredes das galerias, a ideia era tratá-los como duas áreas distintas. ${ }^{192}$

Era o fim dos anos 1950. Naquela época, Warhol já era um artista comercial reconhecido e ilustrava páginas de revistas importantes. Havia feito um bom número de capas de disco e de páginas publicitárias. Era premiado em um meio de design que favorecia cada vez mais a fotografia em detrimento da ilustração. Sabia, no entanto, que não poderia, na ocasião, ter um pé em cada canoa. ${ }^{193} \mathrm{Em}$ depoimentos recentes, personagens importantes da biografia do artista confirmam essa hesitação e contam como ela foi superada. ${ }^{194}$

O fato de a fotografia tomar o lugar das ilustrações feitas a mão no design gráfico talvez fosse uma razão importante para o artista mudar de ramo, mas parece pouco. Ciente do arrivismo de Warhol, Thomas Crow afirma que quando essa mudança começa, Warhol "percebe uma diminuição de espaço" em seu campo de atuação. "As

\footnotetext{
${ }^{192}$ A transição de artista comercial para artista plástico, bem como a confusão de um campo com o outro é discutida em textos como: BUCHLOH, Benjamin. Andy Warhol's onze dimensional art. Em MICHELSON, Atente (Org.) Andy Warhol (October Files). Cambridge: MIT Press, 2001; e CROW, Thomas. Saturday night disasters: trace and reference in early Warhol. Em MICHELSON, Anette (Org.) Andy Warhol (October Files). Cambridge: MIT Press, 2001.

O tema da continuidade do trabalho entre a ilustração e as artes de museu é discutido desde os anos 1980. Dois textos muito importantes para essa discussão são: BUCHLOH, Benjamin. Andy Warhol's one dimensional art. Em MICHELSON, Anette (Org.) Andy Warhol (October Files). Cambridge: MIT Press, 2001; e RATTCLIFFE, Carter. Andy Warhol. Nova York: Abeville Press, 1983.

Em um estudo mais recente, John J. Curley aponta continuidades interessantes entre a produção comercial e a produção para galerias a partir da ideia de blotted line. CURLEY, John J. "Chapter 2: The development of Andy Warhol's Pop Eye”. Em CURLEY, John J. A Conspiracy of images: Andy Warhol, Gerhard Richter and the art of the Cold War. New Haven: Yale University Press, 2013.

${ }^{193}$ Em WARHOL, Andy; HACKETT, Pat. Popismo: os anos 60 segundo Warhol. Trad. José Rubens Siqueira. Rio de Janeiro: Cobogó, 2013. O artista escreve que "(...) Se você queria ser considerado um artista 'sério' não podia ter nada a ver com a arte comercial". p. 22.

${ }^{194}$ KARP, Ivan. "Andy Starts to paint”. Em GOLDSMITH, Kenneth (Org.) Andy Warhol Giant Size. Londres/Nova York, 2006.
} 
artes plásticas aparecem tanto como necessidade quanto como aspiração". ${ }^{195}$ Não há ainda nada de definitivo que explique a prioridade que Warhol passa a dar às artes plásticas, mas o argumento de Crow é convincente. Os depoimentos de época reforçam a diferença entre uma coisa e outra no trabalho de Warhol. No entanto, por mais que expurgasse o artista comercial que morava nele, Warhol carrega algumas das convenções e questões do trabalho anterior em sua pintura. ${ }^{196}$ Mais que isso, as questões da ilustração parecem ser aprofundadas nas primeiras pinturas exibidas por Warhol. ${ }^{197}$ Um caráter falhado, apagado, incompleto dos desenhos é central por toda a trajetória do artista.

Como ilustrador, Warhol parecia levemente antiquado. Era muito elegante, mas remetia ao desenho dos realistas americanos, especialmente a Ben Shahn. ${ }^{198}$ Seu estilo era frágil, feito com uma técnica que tornava a linha quebradiça, um pouco manchada; surgia o contorno de suaves silhuetas, mostradas parcialmente, em um espaço

\footnotetext{
${ }^{195}$ CROW, Thomas. The long march of pop: art, music and design 1930-1995. New Haven: Yale University Press, 2014. p. 167.

${ }^{196}$ BUCHLOH, Benjamin. Andy Warhol's one-dimensional art. Em MICHELSON, Anette (Org.) Andy Warhol (October Files). Cambridge: MIT Press, 2001; e CROW, Thomas. Saturday night disasters: trace and reference in early Warhol. Em MICHELSON, Anette (Org.) Andy Warhol (October Files). Cambridge: MIT Press, 2001. FOSTER, Hal. "Andy Warhol, or the distressed image". Em The first pop age. Princeton: Princeton University Press, 2012.

${ }^{197}$ Benjamin Buchloh comenta a ambiguidade de Warhol, que se apresenta como artista de museu no mundo das artes gráficas e mente ser autodidata nas suas primeiras exposições. As duas blagues são vistas como maneiras de uma parte do trabalho tentar validar a outra: "These strategically brilliant blagues (encoding the avant-garde's communication with its bourgeois audience, most aptly practiced by Baudelaire, Wilde, and Duchamp and brought up to late twentieth-century standards by Warhol) indicate Warhol's early awareness of the rapidly changing relationships between the two spheres of visual representation and the drastic changes of the artist's role and audience's expectations at the beginning of the 1950s". Em BUCHLOH, Benjamin. Andy Warhol's one dimensional art. Em MICHELSON, Anette. (Org.) Andy Warhol (October Files). Cambridge: MIT Press, 2001. p. 3-4.

${ }^{198}$ A influência de Ben Shahn na formação de Warhol é apontada em boa parte da bibliografia. Thomas Crow menciona o artista ao falar das idas e vindas de Warhol entre as artes plásticas e a arte comercial. CROW, Thomas. The long march of pop: art, music and design 1930-1995. New Haven: Yale University Press, 2014. p. 168-171). James Curley ao comentar os primeiros desenhos de Warhol, de conteúdo politico, também menciona Shahn: "The sincere, politically engaged work of Ben Shahn, evident in the working-class subjects was model for Warhol (...) Shahn was a prevailing hero of the period. Jackson Pollock and other Abstract Expressionists are largely unknow in Pittsburgh. Em CURLEY, John J. A Conspiracy of images: Andy Warhol, Gerhard Richter and the art of the Cold War. New Haven: Yale University Press, 2013. p. 55.
} 
em branco sem cenário. Como o contorno mostrava falhas, as figuras lineares, desprovidas de sapatos, saias, cabeças pareciam desvanecer.

A "linha borrada" (blotted line), sua assinatura, era uma espécie de monotipia. O artista desenhava sobre superfície pouco absortiva e depois imprima o seu desenho em uma folha em branco. Frequentemente, tomava esse papel ainda molhado e o pressionava sobre outro papel. A imagem usada como clichê gráfico, em geral, era a segunda impressão do papel. O original era descartado. Tal como o artista trabalhará mais tarde, essa imagem se mostra como uma lembrança distante do objeto figurado, como um resquício de uma representação. De fato, o papel que víamos era uma cópia de uma imagem, uma versão indireta de outra representação. Claro que se olharmos, por exemplo, para os anúncios da loja de sapatos I. Miller, de 1957 (36), essa ideia de imagem reprodutível não está presente, mas talvez ela fosse uma questão. Tanto que essa figuração falhada, manchada, com dificuldades de visualização da figura, feita a partir de um original descartado, será reinterpretada pelo artista de outros modos ao longo de sua carreira. Isso aparecerá na serigrafia e até em alguns filmes do artista. ${ }^{199}$

De qualquer forma, tanto a vontade de se livrar dos temas e das técnicas anteriores, como de aprofundar questões da ilustração apareceram nas suas primeiras pinturas dos anos 1960. Warhol escolhe temas gráficos recortados de pedaços de anúncios e de histórias em quadrinhos. Depois os refaz com um tratamento pictórico mais despojado, gestual. Em geral, pinta com tinta sintética ou diluída em caseína. A tinta é bastante líquida, escorre, como o material de Pollock, e nos faz ver as marcas de pinceladas largas de outras demãos antes da última camada de pintura.

\footnotetext{
${ }^{199}$ Penso, sobretudo, na primeira parte, mais desfocada, de Poor Little Rich Girl.
} 
Se tomarmos Dr. Scholls Corns (1960) (35) e Nancy (1960) (37), ${ }^{200}$ notamos algumas recorrências em termos de escolha do tema a ser trabalhado e da maneira como o artista trabalhava. O desejo de se distanciar da publicidade aqui se mostra de diversas formas. Embora se valha dos temas saídos de impressos da publicidade, ou do mundo do entretenimento, o artista escolhe temas ligados não à satisfação, mas ao incômodo. Pinta um anúncio de emplastos para a cura de calos e um trecho todo recortado e editado de Nancy, criação genial de Ernie Bushmiller (38-40), ${ }^{201}$ congelando sob a neve. Nancy era uma história em quadrinhos apresentada em uma arquitetura muito clara, com distribuição dos espaços retilíneos, com pouca variação de imagens de um quadrinho para outro. ${ }^{202}$ Uma das graças era essa discreta mudança de percepção.

Na pintura de Andy Warhol, as linhas que delimitam os quadrinhos se tornam irregulares. Alguns elementos distintivos da personagem, que reclama de frio, são apagados. Um branco irregular retira a solidez de todos os elementos, desfazendo, inclusive, o limite entre o quadrinho de cima e o de baixo. Warhol retira o colete de Nancy, retira o contorno de suas botas vermelhas e usa um branco dramático para enfatizar o frio da personagem. Ela surge levemente desfeita, perdendo os pés na massa branca desobediente que se faz neve.

\footnotetext{
${ }^{200}$ As fontes utilizadas não são conclusivas na datação das pinturas. Ambas aparecem em alguns livros como telas de 1961. Uso a periodização do catálogo da retrospectiva do Museum of Modern Art de Nova York (MoMA) para datar os trabalhos.

${ }^{201}$ É possível identificar as razões que levam Warhol a escolher alguns personagens das histórias em quadrinhos e não outros. Além de Nancy, Warhol pintou Superman (criado por Joe Shuster e Jerry Siegel); Batman (criado por Bob Kane); Popeye (criado por E.C. Seagar); Dick Tracy (criado por Chester Gould); e Little King (criado por Otto Soglow). Todos são personagens de uma era de ouro dos quadrinhos, que coincide com a Grande Depressão. Esses personagens todos representam inovações narrativas e gráficas aos quadrinhos e à comunicação de massa de uma forma geral. Abandonam-se as narrativas mais livrescas, por um ritmo mais veloz e pop. Nancy é especialmente moderna. Estudos como "How to Read Nancy", de Mark Newgarden e Paul Karasik, vão discutir o caráter modernista da tira de Ernie Bushmiller, sua economia de traços e sua brincadeira com a verossimilhança da narrativa e a imagem. Cf. NEWGARDEN, Mark; KARASIK, Paul. "How to Read Nancy". RAW Magazine, v. 1, 1986. pp. $98-105$.

${ }^{202}$ Não por acaso, Bushmiller se torna um dos ídolos de Samuel Beckett. Eles chegam a se corresponder nos anos 1950. Cf. HAMRAH, A. S. "The Beckett/Bushmiller Letters". Hermenaut, n. 15, 1999. Disponível em: http://theamericanreader.com/the-beckettbushmiller-letters/. Acesso em: mar. 2016.
} 
Em Dr. Scholl's Corns (35), Warhol refaz um pequeno anúncio de jornal dos Zino-Pads daquela marca: emplastros que, segundo o anúncio, curariam quaisquer calos, joanetes ou dedos doloridos. O artista amplia o anúncio e retira o leve sombreado tanto do pé pintado quanto do dedo da mão que retira um dos pads que havia no anuncio gráfico. O pé aparece em cinza, como se, de maneira primitiva, buscasse uma cor que não é própria da pintura, mas da fotografia, mais especificamente, da fotografia tal como publicada na imprensa. O dedo indicador levanta um dos emplastros e justamente nos mostra uma marca de ferida no terceiro dedo.

No anúncio gráfico original, há dois letreiros. O primeiro vem no cabeçalho, quase como uma manchete: "Corns" (na primeira linha) e "Callouses, Bunions or Sore toes?" (na segunda linha). Embaixo, logo acima do pé, aparece um balão crispado com os dizeres: “Dr. Scholl's Zino-pads/ STOP PAIN/ Almost Instantly”. Ou seja, o design, como nas formas mais tradicionais de publicidade, apresenta um problema na primeira parte do texto, ilustra-o na base e oferece uma solução no balão.

Na transposição para a pintura, contudo, Warhol faz modificações, não só no desenho do pé, mas também nos balões e nos letreiros. O balão é pintado de maneira gestual, irregular. O canto esquerdo é deixado em branco. A tinta é líquida e escorre sobre o dedão. $\mathrm{O}$ canto esquerdo inferior do balão não é preenchido por tinta, mas por uma camada irregular de giz de cera. Aliás, esse mesmo giz de cera risca uma coluna torta no canto da tela, colorida de maneira rápida e descuidada. Toda a imagem parece fora de esquadro, com os dizeres desarrumados.

Mais do que entortar o arranjo gráfico, o artista apaga algumas palavras. No alto do quadro, à esquerda, levemente na diagonal, lemos "Corns", com as letras manchadas e mal coloridas. No balão, meio que se apagando, lemos apenas o nome da marca de produtos ortopédicos, “Dr. Scholl”. Diferente do anúncio, aqui os calos são 
diretamente associados à marca. Não se trata de um anúncio de um emplasto curativo, mas de um anúncio de calos. Como bem observa John J. Curley, não é o alívio que é enfatizado na pintura, mas o incômodo. ${ }^{203}$

O historiador vai ainda mais longe, relaciona a pintura $D r$. Scholl's às campanhas publicitárias de sapato que Warhol criava para a I. Miller. A pintura irregular, manchada, atabalhoada e incompleta de Warhol parece se distinguir do design limpo e sintético de seus anúncios. Se na propaganda o sapato era apresentado, dentro do discurso publicitário adequado, como um complemento dos pés, um sinal de perfeição e elegância, na pintura o corpo aparece desajeitado, perturbado, para os critérios das artes gráficas. ${ }^{204}$ Assim, o significado da obra poderia ser interpretado como a descrição dos efeitos colaterais de se adequar à elegância mostrada no anúncio de sapato, os efeitos escamoteados pela campanha publicitária. Embora o argumento soe forçado, pois não parece haver evidência de que Warhol seja um crítico per se do consumismo, ${ }^{205}$ essa relação entre a imagem e uma existência física dissociada dele é verdadeira.

Em outra interpretação importante, Thomas Crow vê a série de pinturas Tunafish disasters (1963) (41) ${ }^{206}$ como um avesso da publicidade. A tela é mais composta, embora feita com serigrafia. Nela, Warhol sobrepõe três elementos em diferentes disposições: imagens de uma lata de atum, o retrato de duas mulheres de Detroit (Mrs. Brown e Mrs. MacCarthy) que morreram em decorrência de uma intoxicação alimentar do produto contaminado e legendas que sugerem o que aconteceu.

\footnotetext{
${ }^{203}$ CURLEY, John J. A Conspiracy of images: Andy Warhol, Gerhard Richter and the art of the Cold War”. New Haven: Yale University Press, 2013. p. 70.

${ }^{204}$ Idem, p. 73.

${ }^{205}$ Curley se apoia nos seus desenhos de Pittsburgh e em um debate sobre o que há de farsesco na imagem e nas notícias da época. Idem, capítulo 1.

${ }^{206}$ CROW, Thomas. Saturday night disasters: trace and reference in early Warhol. Em MICHELSON, Anette. (Org.) Andy Warhol (October Files). Cambridge: MIT Press, 2001. p. 57.
} 
A tragédia havia sido noticiada na revista Newswee ${ }^{207}$. Warhol compõe a tela a partir das fotografias das senhoras e do produto publicadas na revista. ${ }^{208}$ Ele alterna as imagens serialmente, dispondo as fotografias sobre as latas e as legendas sob as latas. São seis fotos alternadas das duas vítimas, três fotos da mesma lata de peixe estragado e a legenda equivalente a cada uma das latas ${ }^{209}$.

A tragédia não é anunciada nas imagens. A fotografia da lata é protocolar e o retrato das duas senhoras é bastante simpático. A princípio trata-se da associação de um produto com duas desconhecidas. A tela poderia ser, inclusive, confundida com uma campanha publicitária dos anos 1950. Entendemos as circunstâncias porque embaixo da lata se explica o caráter mortífero do produto. Diz a legenda: "Remessa apreendida: uma escapou e matou..."210 Mais uma vez, o acidente não está na imagem. A fotografia, como o próprio Warhol afirma, traz uma dimensão incompleta dos retratados, uma "meiadimensão". ${ }^{211}$ A tragédia acontece ao redor da imagem, na vida. Aliás, como afirma Barbara Miller, a corrosão da lógica do consumo, de sua satisfação se dá no interior do produto, não em sua aparência. ${ }^{212}$

Crow, ao comentar esse trabalho, insiste na relação no mínimo problemática de Warhol com a sociedade de consumo. Não tenho elementos nem para comprovar nem para refutar inteiramente a tese ${ }^{213}$ porém, há, tanto nas análises de Crow, como nas de

\footnotetext{
${ }^{207}$ MILLER, Barbara L. "Gingerbread Houses: art, food and the postwar architecture of the domestic places". Em HORWITZ, Jamie; SINGLEY, Paulette (Orgs.) Eating Architecture. Cambridge: MIT Press, 2006. p.139.

${ }^{208}$ A versão comentada tanto no texto de Thomas Crow como aqui é a que está na Saatchi Gallery, em Londres.

${ }^{209}$ Existem outras variações dessa pintura com ligeiras mudanças de disposição e de significado.

210 "Seized shipment: did a leak kill..."

${ }^{211}$ WARHOL, Andy. A filosofia de Andy Warhol. Rio de Janeiro: Cobogó 2008. p. 79.

${ }^{212}$ MILLER, Barbara L. "Gingerbread Houses: Art, food and the postwar architecture of the domestic places”. Em HORWITZ, Jamie; SINGLEY, Paulette. (Orgs.) Eating Architecture. Cambridge: MIT Press, 2006. p. 139.

${ }^{213} \mathrm{Hal}$ Foster, em um argumento convincente, acredita que o engajamento que Crow vê em Warhol é uma projeção dele e do seu gosto. Em FOSTER, Hal. O retorno do real. Trad. Célia Euvaldo. São Paulo: Cosac Naify, 2014. p. 125.
} 
Curley, uma oposição útil, que parece presente na trajetória de Warhol o tempo todo: a oposição entre os acontecimentos na imagem e no mundo. Assim como Curley opõe o trabalho de arte à publicidade, Crow mostra um aspecto ambíguo das imagens em relação à tragédia.

Mais do que falar da denúncia do capital, Curley acredita que Warhol fala dos códigos, dos códigos ideológicos que parecem significar todas as relações daí em diante. ${ }^{214}$ Por isso, quando comenta pinturas como Thirty-Five Jackies (1964) (42), o autor acredita que não podemos chamá-las de pinturas históricas. ${ }^{215}$ No entender de Curley, elas se aparentam mais com a conspiratória ideia de mensagem criptografada. ${ }^{216}$ Uma imagem que ninguém entende muito bem o que comunica, que parece comunicar algo pela metade.

Dessa forma, como em Tunafish disasters (1963) (41), a imagem apropriada se mostra como uma narrativa que corre em paralelo aos acontecimentos factuais. Seja para amplificar um personagem, seja para anestesiar um fato, a narrativa é a linguagem da propaganda, da persuasão, de certo fascínio. No entanto, ela olha para a vida e vê ali algo de ordinário. Essas imagens foram feitas em um momento em que Warhol abandona a pintura tradicional e começa a manipular fotografias, fotogramas de filme e fotolitos. Esse sentido foi construído nesses poucos anos.

Nessas imagens de que Warhol se apropria, os objetos, as personagens, os produtos, tudo ganha um grau de idealização publicitária que as torna lisas, perfeitas,

\footnotetext{
${ }^{214}$ CURLEY, John J. A Conspiracy of images: Andy Warhol, Gerhard Richter and the art of the Cold War. New Haven: Yale University Press, 2013. p. 119.

${ }^{215}$ Indiretamente, o autor aqui polemiza com o importante artigo de Robert Rosenblum, "Warhol as art history. Em McSHINE, Kynaston. (Org.) Andy Warhol: A retrospective. Nova York: The Museum of Modern Art, 1989.

216 "They are more like encrypted communiques than historical narratives. Instead of history painting, they offer conspiracy theory, challenging viewers to see through the conflict's [no caso, a Guerra Fria] ideological blindness". Idem, p. 118-9.
} 
sedutoras. Ainda de maneira mais ingênua, as duas pinturas de 1961 parecem mostrar o avesso disso. Nelas, aquelas imagens parecem incompletas, mal-ajambradas, escorridas e físicas. Warhol associa esse caráter incompleto a um caráter mais ordinário, atabalhoado e doloroso da vida. Usa isso para se contrapor à perfeição das imagens, suas convenções de sedução e sua promessa de felicidade. Nesse sentido, esse caráter "criptografado", reivindicado por Curley, é verdadeiro. A imagem midiática é capaz de trazer sentidos que o objeto, a pessoa e o produto não têm na vida, assim como elimina alguns dos predicados corpóreos. $^{217}$ Daí em diante, Warhol abandona o caráter pictórico e seu trabalho se aprofunda na lógica e na manipulação das imagens que antes ele pintava a mão. Parece fazer pouco sentido reproduzir narrativas, composições e personagens que só conhecemos por imagens do cinema, da televisão e da foto. Por isso, o artista decide transferir a imagem fotográfica diretamente para a tela, mas sem que aquilo parecesse uma colagem. Warhol passa a pensar a partir desses códigos que se multiplicam, que ganham sentido diverso de acordo com o contexto e se esvaziam na medida em que se repetem sobre uma superfície.

Em 1962, Warhol decidiu abandonar os pincéis e adotar processos gráficos bastante simples para ocupar a tela. $\mathrm{O}$ artista tentou estêncil, carimbos, decalques e outros métodos antes de adotar a serigrafia (silkscreen).

\footnotetext{
${ }^{217}$ Em dois trechos de A Filosofia de Andy Warhol, o dualismo entre o que acontece no cinema, nas fotos e o que acontece na vida é explorado: "dizem que o jeito como as coisas acontecem nos filmes é irreal, mas na verdade é o jeito como as coisas acontecem com você na vida que é irreal. O cinema faz as emoções parecerem tão fortes e reais, enquanto as coisas que acontecem na realidade são como assistir tevê - você não sente nada" (p. 107); ou "As únicas belezas inequívocas são as das estrelas de cinema, e na vida nem as estrelas de cinema chegam perto dos padrões que elas estabelecem nos filmes" (p. 84). Em WARHOL, Andy. A filosofia de Andy Warhol. Rio de Janeiro: Cobogó, 2008.
} 
Até aí, Warhol havia eliminado muito do que o aproximava da ideia que se fazia de pintura moderna ${ }^{218}$ em Nova York. ${ }^{219}$ As marcas de pincelada, a irregularidade do plano, o escorrido da tinta e as mudanças nas imagens não estavam em trabalhos importantes como 32 Sopas Campbell (1962) (165). Exposto pela primeira em 1962 na Ferus Gallery, em Los Angeles, e mais tarde, em Nova York, na coletiva The New Realists, na galeria de Sidney Janis, ${ }^{220}$ o trabalho mostra um desinteresse tanto pela ideia de originalidade quanto pela ideia de estilo moderno. O artista, por meio de estêncil, transfere a mesma imagem para 32 telas. É a reprodução gráfica das latas dos 32 sabores disponíveis das sopas Campbell. A variação é mínima. Basicamente, a diferença é o que vem escrito no rótulo. ${ }^{221}$

$\mathrm{O}$ artista repete a imagem como um logotipo, um ícone comercial que toma a tela e identifica a obra com o produto dos mais ordinários. Aliás, ele distribui as imagens em uma composição serial, como em uma prateleira. Assim como o sabor das sopas é sempre o mesmo, as pinturas também são. Aqui, a ideia de série parece bastante diversa do uso que se fez das séries na pintura moderna.

Um dos pioneiros nas séries modernas foi Claude Monet. Quando realizava as suas paisagens em momentos distintos do dia, se valia de uma estratégia para capturar a mesma vista de maneiras distintas. Naquelas séries, nunca temos a mesma experiência

\footnotetext{
${ }^{218}$ Cf. GUILBAUT, Serge. How New York Stole the Idea of Modem Art: Abstract Expressionism, Freedom, and the Cold War. Chicago: University of Chicago Press, 1993.

${ }^{219}$ Esse é o tema central da minha dissertação de mestrado. MESQUITA, Tiago. Através do espelho: A constituição da pintura inicial de Andy Warhol (1956-1968). Dissertação de Mestrado apresentada ao Departamento de Filosofia da Faculdade de Filosofia, Letras e Ciências Humanas da Universidade de São Paulo (FFLCH-USP), São Paulo, 2009.

${ }^{220}$ Por conta dessa exposição, entre 31 de outubro e 1 de dezembro de 1962, Brian O'Doherty, em um artigo importante em The New York Times, atesta que é chegada a era da pop. Critica a escolha do nome europeizado da exposição, "Novos realistas", Pois essa mostra parece dizer respeito a outra coisa. Sem saber se gosta ou não do que vem por aí, ele afirma: "With this show, "pop' art is officialy here". O’DOHERTY, Brian. “Art: Avant-garde revolt (1962)”. Em MADOFF, S.H. (Org.) Pop Art: A critical history. Berkeley: University of California Press, 1997. p. 42.

${ }^{221}$ Há uma pequena diferença na pintura que copia a lata de Cheddar Cheese. Ela possui duas faixas amarelas com letreiros. Um diz que a sopa é um novo sabor, outra avisa que a sopa é "ótima como molho também! ".
} 
diante do mesmo lugar. As descrições em cada representação são inteiramente distintas. Muda a cor, muda o modo de pintar, muda a atmosfera, só não muda o tema. Warhol não lida mais com a busca de uma imagem única, irreprodutível, resultante de um estilo inconfundível. O estilo aqui é a falta de estilo. Como nota Benjamin Buchloh: “A posição de Warhol de afirmação implacável [do caráter serial e idêntico das pinturas] cancela qualquer aspiração e liquida a dimensão metafísica do legado modernista por submeter cada pintura a um enquadramento idêntico enquanto produto, imagem e preço". 222

Benjamin Buchloh ressalta que embora as diferenças entre a primeira e a segunda gerações da escola de Nova York sejam notórias, é importante enfatizar que não se trata de uma mudança súbita de paradigma. Os expressionistas abstratos ainda não haviam atingido o cume do seu prestígio quando os artistas da pop começaram. Além disso, embora buscassem efeitos estéticos opostos, artistas mais jovens como Johns, Oldenburg e Warhol não se cansavam de expressar "contínua e enfaticamente sua afiliação e veneração ao legado do expressionismo abstrato em seus trabalhos e declarações, da mesma forma em que enfatizavam igualmente a impossibilidade de atingir, muito menos continuar, seus padrões e suas aspirações artísticas transcendentais. $^{223}$

Warhol especificamente parece interessado não só nessas novidades comerciais, mas também em uma imagem que sempre é a mesma. O trabalho sugere não uma relação contemplativa, mas de consumo rápido. Aqui, mais importante do que representar um produto banal, é representar uma imagem de um produto, que não se confunde com o caráter físico dele e é invariável. O artista vai mais longe que negar a originalidade, a autoria, a afirmação romântica de um tipo de subjetividade moderna. Ele

\footnotetext{
${ }^{222}$ BUCHLOH, Benjamin. Andy Warhol's one-dimensional art. Em MICHELSON, Anette (Org.) Andy Warhol (October Files). Cambridge: MIT Press, 2001. p. 32.

${ }^{223}$ Idem, p. 12.
} 
faz isso a partir de um elemento dado, retirado de outro lugar e isento de qualquer característica que o particularize. É uma imagem, que serve para identificar um objeto, mas diferentemente dele é invariável e incorpórea.

Warhol indicava a emergência de um tipo de artista de outra natureza. Embora o seu trabalho não fosse uma polêmica contra a pintura moderna, Warhol parecia marcar, sobretudo depois de 1963, uma nova relação da arte com a imagem da cultura de massa. A pintura tenta se assemelhar a ela, trabalhar como ela. Mais importante, no entanto, que "reconciliar a indústria cultural com a alta cultura", Warhol parece notar um regime de imagens que serve à identificação dos produtos, à construção dos ídolos e à definição de melancólicas novas aspirações de felicidade.

Quando ele comenta, em seu Popismo, sobre um grupo de jovens burgueses ansiosos, entre eles sua futura superstar Edie Sedgwick, que começa a frequentar a boêmia de Nova York no começo dos anos 1960, revela que parte do tédio daquelas garotas e garotos dizia respeito à vida regrada e pacata que eles levavam nos campi das universidades americanas de elite. Segundo Warhol, eles chegavam das prósperas cidades da Nova Inglaterra resmungando muxoxos como: “Ah, meu Deus, que tédio, estamos tão cansados de ir a aula. Queremos mudar para o mundo real". Warhol explica aos seus leitores que naquele contexto, "Mudar para o mundo real queria dizer ver sua foto nos jornais e ser mencionado nas revistas". ${ }^{224}$ Tornar-se imagem era ir para a vida, para o lugar onde as coisas acontecem, e não viver da passividade pacata dos bem-nascidos.

$\mathrm{O}$ assunto nem era tão repentino. Warhol tentava pintar fotografias pelo menos desde 1961. Quando ele fez imagens das páginas de tabloides, incomodou-se por não conseguir evitar gestos interpretativos na transposição da imagem gráfica para a

\footnotetext{
${ }^{224}$ WARHOL, Andy; HACKETT, Pat. Popismo: os anos 60 segundo Warhol. Trad. José Rubens Siqueira. Rio de Janeiro: Cobogó, 2013. p. 123.
} 
pintura. As figuras se tornavam algo muito distinto do seu referente. Com a serigrafia, ele inaugura um novo procedimento. $\mathrm{O}$ procedimento é relativamente similar à pintura $\mathrm{e}$ passa por etapas parecidas. Warhol compra os direitos da fotografia. Fotografa-as de novo e as imprime em uma tela de silkscreen. Dali, transfere aquelas imagens serialmente, quantas vezes quiser, em diferentes pinturas cobertas com cores berrantes. As imagens são repetidas como produtos em uma prateleira. Por vezes justapostas, por vezes sobrepostas, por vezes em arranjos menos regulares.

Uma cultura de imagem havia se generalizado naquela época. Esse imaginário servirá de fonte para gerações dali em diante. Lugares distantes do mundo, antes inacessíveis, aparecem nos filmes, na televisão. Pessoas passam a acompanhar narrativas construídas da vida, dos amores e dos infortúnios das pessoas famosas. A narrativa da vida de astros da música, do cinema, da televisão e do esporte passa a ser contada além das telas, nas revistas. A imagem recria um reflexo do mundo. Embora ele seja parcial, afeta multidões.

Muito do que Warhol pensa das imagens vem desse tipo de relação encenada do personagem na imagem, na qual o que está sendo representado não é somente a figura de uma personalidade reconhecível. ${ }^{225}$ Warhol transpõe para a pintura um uso que a fotografia havia adquirido para o mercado de informações em massa. Trata da conversão dos acontecimentos, dos personagens, dos objetos nessa "meia-dimensão" em que eles não são exatamente como o referente retratado, mas também não deixaram de ser o que

\footnotetext{
225 Trato desse tema na minha dissertação de mestrado, Através do espelho (2009). Repito o que escrevi lá: "Em seus retratos de 1963 e 1964, Andy Warhol ajunta imagens em que esses personagens muitas vezes estão a encenar. Imagens de um teatro que disfarça o retratado e o apresenta como um personagem ficcional. Um fantasma criado por aí e que agora existe em um imaginário sustentado pela grande e poderosa máquina dos meios de comunicação de massa. Mas são personagens que, mesmo quando vistos, não são quem são na tela”. Em MESQUITA, Tiago. Através do espelho: Andy Warhol (1956-1968). Dissertação de mestrado apresentada ao Programa de Pós-Graduação do Departamento de Filosofia da Faculdade de Filosofia, Letras e Ciências Humanas da Universidade de São Paulo, 2009. p. 34.
} 
eram antes. É essa instância do tornar-se ou não personagem, que o artista buscará mais tarde em seus testes de câmera.

Segundo o jornalista David Dalton, o primeiro silkscreen de uma fotografia foi Baseball (43). ${ }^{226}$ Baseando-se em uma fotografia de jogo, a imagem captura o momento em que o rebatedor flexiona os braços e se prepara para atingir a bola que vem na diagonal. Atrás dele, o pegador está de cócoras. $\mathrm{O}$ artista distribui as imagens em faixas da esquerda para a direita, de cima para baixo. A disposição lembra os fotogramas do cinema, embora a imagem seja sempre a mesma. A partir da segunda coluna, a distância entre uma fotografia e a outra fica menor. As imagens começam a se sobrepor e a se confundir. Nas linhas de baixo, tudo se torna uma mancha negra, esfumaçada e indistinta. As imagens repetem o mesmo gesto. Reiteram um acontecido lembrado pela imagem, até que, de tanto repetir, ela se esquece do que contava.

Esse caráter de "meia-dimensão"227 vista por Warhol nas fotografias de revista, o levará ao mundo da fama. Da mesma maneira que ele empilha caixas, latas, dólares, objetos, passa a empilhar as imagens dos ídolos do cinema. Sua primeira série, parte do álbum de figurinhas Teen Stars, ${ }^{228}$ com imagens dos ídolos de matinê, como Troy Donahue, Warren Beatty, Natalie Wood, Hedy Lamarr. Warhol distribui as efígies pouco sólidas em um gradeado gráfico.

Como o artista - ou os seus assistentes - nem sempre usa a mesma carga de tinta para gravar as figuras sobre esse fundo, elas por vezes surgem mais nítidas, por vezes mais apagadas ou mais manchadas. As primeiras surgem sobre o branco, depois, as imagens em alto-contraste, em preto e branco, com pouca definição de volume passam a

\footnotetext{
${ }^{226}$ DALTON, David. "Matinee Idols". Em GOLDSMITH, Kenneth. (Org.) Andy Warhol Giant Size. Londres/Nova York, 2006. p. 174.

${ }^{227}$ WARHOL, Andy. A filosofia de Andy Warhol. Rio de Janeiro: Cobogó, 2008. p. 79.

${ }^{228}$ GOLDSMITH, Kenneth (Org.) Andy Warhol Giant Size. Londres/Nova York, 2006. p. 176.
} 
sombrear os fundos de cores brilhantes. As imagens se repetem na tela, ininterruptamente, como se aparecessem e desaparecessem; como se sugerissem uma presença oscilante dos personagens. As pinturas de astros como Warren Beatty, Troy Donahue (44I), Elizabeth Taylor dão a impressão de que a progressão daqueles retratos começou antes da tela e seguirá para além dela. ${ }^{229}$ É como se as imagens fossem, portanto, aparições.

As imagens escolhidas são de pessoas ou eventos amplamente reconhecíveis, mas não são conhecidos pelo contato direto com as pessoas, e sim por suas representações midiáticas. $\mathrm{O}$ artista mergulha nesse sistema de idolatria triste, no qual os personagens só existem como imagens. Sabe-se das crises conjugais de Elizabeth Taylor pelas imagens e pelas fofocas. Quando Liz se divorcia, é uma Cleópatra (51) que se divorcia. Podemos dizer o mesmo dos problemas com anfetamina de Elvis Presley e da beleza, da glória e da morte de Marilyn Monroe. As tragédias, as comoções, as intrigas, sabemos tudo por essas meias figuras que são as narrativas e imagens midiáticas capazes de nos comover e nos anestesiar.

Em um díptico que Warhol dedica a Troy Donahue (44), em 1962, ele grava a mesma imagem do ator 102 vezes. Ele põe cor em 42 retratos e deixa os outros sessenta em preto e branco. O procedimento é simples: primeiro, ele aplica as tintas coloridas, rosa para o rosto, amarelo para o cabelo, vermelho para a roupa. Depois vem o retrato de Troy Donahue. Embora a imagem seja sempre a mesma, ela surge de maneiras diferentes. Em algumas impressões em preto e branco, vemos indícios apagados do astro; em outras, uma forma borrada. Por vezes, o rosto parece sumir no rosado, em outras os contornos se sobrepõem. Todas as imagens parecem relativamente falhadas. As cores parecem

\footnotetext{
${ }^{229}$ Benjamin Buchloh vê nessa serialização interminável um efeito irônico do all over de Jackson Pollock, sobretudo quando, em 1966, o seu trabalho é impresso em papéis de parede. BUCHLOH, Benjamin. Andy Warhol's one-dimensional art. Em MICHELSON, Anette. (Org.) Andy Warhol (October Files). Cambridge: MIT Press, 2001. p. 32.
} 
desencontradas com o contorno. Como o que está pintado ali não é a figura de carne e osso, mas a sua representação, é como se a imagem estivesse a se descolar do seu referente. Quanto mais repete a figura, mais difícil parece ser recuperá-la. ${ }^{230}$ Hal Foster, pensando no imenso painel de Elvises (47), exposto na Ferus Gallery em 1963, diz que a proliferação das imagens desvaloriza e deteriora os seus significados. ${ }^{231}$

Essa dificuldade de tornar as "belezas fotográficas" (para me valer do termo de Warhol) palpáveis, presentes, é que faz suas pinturas de Marilyn Monroe tão intensas (5254). Warhol resolve pintar sua primeira Marilyn Monroe dias depois da morte da estrela, em 1962. Ele compra os direitos de imagem do still do filme Torrentes da paixão (Niagara, 1953) de Henry Hataway, em que a atriz nos olha de maneira sorridente e sedutora. O artista a faz como um ícone descarnado da saúde, da beleza e do vigor juvenil daqueles anos. Para tentar tornar a representação mais sólida, ele colore a figura, mas a cor, desencontrada dos contornos, parece uma máscara mortuária neon e faz com que aquela imagem seja ainda menos presente.

Michael Fried, em uma interpretação do trabalho de Warhol. ${ }^{232}$ teme que os ícones de Marilyn percam a capacidade de comover as gerações futuras. Sua interpretação leva em conta o comentário que a pintura tem, uma forma quase jornalística que corria o risco, infelizmente, de envelhecer. Aliás, por isso também, ele aproxima o trabalho do artista ao épico, pois Warhol trabalha com os mitos da época em que a pintura foi feita. ${ }^{233}$ Por mais perspicaz que a análise de Fried seja, e ela é, não foi isso que aconteceu. Os

\footnotetext{
${ }^{230}$ FOSTER, Hal. The first pop age. Princeton: Princeton University Press, 2012. p. 131.

${ }^{231}$ Idem, p. 132-4.

232 "Of all the painters working today in the service - or thrall - of a popular iconography Andy Warhol is probably the most single-minded and the most spetacular". Em FRIED, Michael. "From New York Letter" (1962). (Publicado originalmente em Art International, de dezembro de 1962.) Em MADOFF, S.H. (Org.) Pop Art: A critical history. Berkeley: University of California Press, 1997. p. 267. ${ }^{233}$ Idem.
} 
retratos das imagens de Marilyn Monroe especialmente parecem sugerir o efeito oposto: ${ }^{234}$ a imagem de Warhol fortaleceu o mito.

Para Thomas Crow, em seu Long March of Pop, Warhol escolhe imagens determinadas menos para figurar o referente real e mais por sua capacidade de criar símbolos. Ele estaria mais preocupado com a potência estética do ícone do que com sua capacidade de comentar assuntos contemporâneos aos trabalhos. ${ }^{235}$ Mesmo assim, a semelhança com o referente é importante.

Crow menciona a relação com a data de realização de cada um dos trabalhos como um fator desencadeador. Warhol resolve pintar a sua primeira Marilyn Monroe dias depois do suicídio da estrela, pinta Liz Taylor depois da fofoca de uma tentativa de suicídio e pinta Jaqueline Kennedy logo depois do assassinato de seu marido. Mais que isso, Crow nos lembra que as imagens de morte e desastres são feitas também entre os conflitos raciais, o assassinato de JFK e a ressaca cívica que se seguiu depois disso, durante os primeiros meses do governo Lyndon Johnson. Talvez por isso, em 1964, o artista só tenha conseguido mostrar essa série na galeria de Ileana Sonnabend, em Paris. Mas, para Crow, a razão principal está menos na referência aos eventos em si, nos suicídios reais, nos acidentes reais, nos verdadeiros tumultos de rua, e mais na presença dessas imagens falhadas como lembranças de uma tragédia que não abandonava Warhol e seus compatriotas naquela época.

Para Crow, quando Warhol transfere suas serigrafias de Marilyn Monroe para suas pinturas, ele não representa a subjetividade da estrela, como aliás fazem os retratos

\footnotetext{
${ }^{234}$ Aliás, Fried tem toda a razão quando diz que as pinturas de Troy Donahue, por mais finesse técnica que tivessem não tinham a comovente beleza vulgar das Marilyns. O tema não aguenta o caráter icônico da pintura. Por isso, agora falo eu, as Marilyns são insuperáveis. São a imagem perfeita de um tipo de estrelato que começa a sua trajetória descendente nos anos 1960, abrindo a crise do cinema americano que será resolvida pelos novos autores dos anos 1970.

${ }^{235}$ Cf. CROW, Thomas. The long march of pop: art, music and design 1930-1995. New Haven: Yale University Press, 2015. p. 288-304.
} 
da tradição, nem mesmo qualquer grau de humanidade da personagem. O que Warhol faz é criar alegorias. A partir do pensamento de Angus Fletcher, ${ }^{236}$ Crow diz que as pinturas de Warhol lidam com a transformação daquelas celebridades em personagens. Por isso, Elvis é caubói (46), Liz é Cleópatra e Marilyn é um ícone em meio a uma tela dourada (52).

Mais do que qualquer outro retrato do artista, as pinturas a partir da fotografia de Marilyn Monroe se tornaram imagens incontornáveis de um ídolo. As imagens que a figuram no momento em que ela "reencena sua subjetividade 237 " pública. Aqui, Warhol consegue fazer com que a arte opere do mesmo modo que um novo sistema de imagens industrial já fazia: converta os retratados em figuras inatingíveis, associadas à idolatria, ícones religiosos de uma sociedade sem grandes redenções. As imagens falhadas em altocontraste de Warhol não conseguem reconstituir aqueles referentes como pessoas de carne e osso, mas sugerem as estrelas, como se fosse possível descrevê-las. Como a apresentação dos ícones na tela é falhada, essas imagens parecem se distanciar ainda mais de nós. ${ }^{238} \mathrm{O}$ artista as repete, obsessivamente, como se fosse possível trazer essa experiência para perto do espectador. A imagem sugere, mas nunca descreve o retratado em carne e osso. Anuncia-o como uma efígie distante, falhada, manchada. A experiência aliás é essa, de nunca encontrar alguém por trás dessas belezas. Como nas pinturas a partir de 1963, não se consegue encontrar as tragédias da série Mortes e desastres. A impossibilidade de essa imagem mecânica, midiática, publicitária ou criptografada, ${ }^{239}$ de essa imagem-produto, ${ }^{240}$ como prefere Hal Foster, de essa "meia-dimensão", como

\footnotetext{
${ }^{236}$ Idem, p. 71-2.

${ }^{237}$ Idem, p. 307.

${ }^{238}$ Os mitos, as formas de se apropriar da história na obra de Warhol são dadas pela narrativa da cultura de consumo. Tanto os atores das imagens apropriadas, quanto as pessoas que posam para as suas fotografias e atuam em seus filmes podem se tornar personagens. Mas isso dura um frame.

${ }^{239}$ CURLEY, John J. A Conspiracy of images: Andy Warhol, Gerhard Richter and the art of the Cold War. New Haven: Yale University Press, 2013.

${ }^{240}$ FOSTER, Hal. O retorno do real. Trad. Célia Euvaldo. São Paulo: Cosac Naify, 2014. p. 126.
} 
preferia o artista, cumprir sua promessa, restaurar os afetos ou os horrores é um dos assuntos de Warhol. Os retratados são reconhecíveis, mas não estão lá.

Muito disso se apreende nas análises de Hal Foster sobre a pop e sobre Andy Warhol. Diante de respostas que apontam a importância iconográfica da imagem ${ }^{241}$ e de análises que apontam a irrelevância dessas interpretações, ${ }^{242}$ Foster decide buscar um caminho intermediário. Sabe que tanto um lado quanto o outro concordam sobre um aspecto perturbador da imagem de Warhol, mas é difícil saber onde ele mora. Foster acredita que ele está nos procedimentos de repetição de Warhol, no apagamento, na dificuldade que ele estabelece de mostrar integralmente uma imagem.

No seu livro The First Pop Age ${ }^{243}$ Foster organizou diversas ideias publicadas anteriormente para buscar uma interpretação mais abrangente da pop. No livro, ele faz uma síntese do seu pensamento sobre Andy Warhol. ${ }^{244} \mathrm{O}$ autor tenta fazer funcionar no mesmo texto a ideia de "real traumático", desenvolvida em $O$ retorno ao real. ${ }^{245}$ junto com as descrições de procedimentos de apagamento e ausência desenvolvidos em Test subjects $^{246}$ para os filmes e as pinturas.

\footnotetext{
${ }^{241}$ CROW, Thomas. Saturday night disasters: trace and reference in early Warhol. Em MICHELSON, Anette. (Org.) Andy Warhol (October Files). Cambridge: MIT Press, 2001.

${ }^{242}$ Jean Baudrillard escreve: "Assim como não há ordem de realidade na arte pop, mas nível de significação, assim também não existe espaço real - o único espaço é o da tela e da justaposição dos diferentes significados dos diferentes elementos/signos e da sua mútua relação". BAUDRILLARD, Jean. "Pop: arte de consumo". (Publicado originalmente em 1970.) Em A Sociedade de Consumo. Lisboa: Edições 70, 2007. p. 126. Para Baudrillard, Warhol se apropria de referências gráficas e fotográficas diante de uma impossibilidade de apreendermos diretamente o mundo. A arte encenaria um modo de experiência em que certas populações urbanas só teriam contato com o mundo por meio da imagem. $\mathrm{O}$ comentário é feito em meio a uma análise da "lógica do consumo". A pop seria a arte que exporia tal ordenamento. Pois, "a lógica do consumo define-se como manipulação de signos. (...) O objeto perde a sua finalidade objetiva e a respectiva função, tornando-se o termo de uma combinatória muito mais vasta de conjuntos de objetos em que o seu valor é de relação”. Idem, p. 120.

${ }^{243}$ FOSTER, Hal. The first pop age. Princeton: Princeton University Press, 2012.

${ }^{244}$ FOSTER, Hal. "Andy Warhol, or the distressed image". Em The first pop age. Princeton: Princeton University Press, 2012.

${ }^{245}$ FOSTER, Hal. O retorno do real. Trad. Célia Euvaldo. São Paulo: Cosac Naify, 2014.

${ }^{246}$ FOSTER, Hal. "Test subjects". Em October 132 ["Andy Warhol: A Special Issue"; editado por Benjamin H. D. Buchloh]. Cambridge: MIT Press, 2010.
} 
Aqui, como na interpretação mais recente de Thomas Crow, ${ }^{247}$ a imagem não corresponde exatamente a uma descrição adequada do referente nem ao seu falseamento. Aquele símbolo serigrafado comunica o referente, mas também o distancia de nós. ${ }^{248}$ Foster não se pergunta o que permanece do referente depois que ele é transferido repetidamente para a tela. Ele quer entender o que sobra das imagens depois de serem reiteradas, fragmentadas, desgastadas e repetidas.

A análise tem como ponto de partida a interpretação das pinturas de mortes e desgraças de 1963 e 1964. De maneira quase oposta à interpretação mais referencialista e politizada de Crow, ${ }^{249}$ para Foster a repetição de imagens apropriadas de acontecimentos traumáticos não dá conotações imediatas e subentendidas a esses acontecimentos, mas os esvazia. A diferença central está na possibilidade de encontro com o referente. Para Crow, o uso cru dessas imagens nos permite ver o esgarçamento do estilo de vida americano, quando ele se vê no espelho em estado de graça. Para Foster, a relação da imagem é de desencontro. Não encontramos o que está lá, mesmo que identifiquemos o que a imagem descreve.

Assim quando vemos os suicídios, as bombas atômicas, os assassinatos e as desgraças se repetirem obsessivamente, isso não significa, para Foster, que Warhol reforce a presença do horror. A repetição atenua a relação com o choque. As imagens são esvaziadas. No entanto, mais forte que isso, a repetição produz uma relação traumática,

\footnotetext{
${ }^{247}$ CROW, Thomas: The long march of pop: art, music and design 1930-1995. New Haven: Yale University Press, 2015.

248 “(...) o que fascina em Warhol é que nunca se tem certeza desse sujeito por trás: tem alguém em casa, dentro do autômato? Cf. FOSTER, Hal. O retorno do real. Trad. Célia Euvaldo. São Paulo: Cosac Naify, 2014. p. 126.

249 "Personagens alegóricos exigem a aparência de personalidades reais, mas só isso. Eles existem para expor uma única característica ou executar uma única ação, como se estivessem possuídos por uma força sobrenatural. Warhol pode ser visto a sublinhar essas qualidades por meio da repetição, inércia, elipse e abstração na transformação técnica de seus materiais apropriados. O êxito de qualquer projeto alegórico depende, além disso, da disposição dos elementos emprestados de tal forma que seu significado imediato será intencionalmente obscuro em qualquer ocorrência ou leitura apressada". CROW, Thomas: The long march of pop: art, music and design 1930-1995. New Haven: Yale University Press, 2015. p. 304.
} 
já que não conseguimos lidar com aquele objeto que parece fugir de nós. As imagens reforçam um encontro sempre faltoso com o real.

Foster se vale de ferramentas da psicanálise lacaniana para explicar: as repetições de Warhol não são restauradoras nesse sentido; não se trata do controle sobre o trauma. Mais do que uma libertação paciente por meio do luto, as repetições "sugerem uma fixação obsessiva no objeto da melancolia (...). De alguma forma, nessas repetições, então, ocorre uma série de coisas contraditórias ao mesmo tempo: uma evasão do significado traumático e uma abertura em sua direção, uma defesa contra afetos traumáticos e sua produção".250

Para o autor, repetição não é representação. Quando Warhol reitera, ele ressalta a dificuldade de se recuperar o real, não de se marcar sua presença. O real parece irrecuperável aqui. A imagem da pintura é perturbadora não por seu conteúdo, mas por estar completamente esvaziada de qualquer conteúdo afetivo. A imagem em Warhol, para Foster, é desencontro. Mesmo quando ela aparenta transparência, é falhada, irregular. O artista nos faz ver os objetos aparecerem e desaparecerem na grade de imagens seriadas, deixa partes apagadas e manchadas nos trabalhos pintados. Nos anos 1970, fez tantas fotografias, que as imagens também perdiam o sentido, perdiam o valor. Em trabalhos menos contrastados, como as Camuflagens (1986), os Diamond dust shoes (1980) e as Flores (1964), a figura se mistura com o fundo. As imagens se tornam indistintas.

Assim, Warhol busca a repetição não só para enfatizar o caráter serial da imagem, mas para abalá-la. Essa perturbação é nítida em trabalhos como The Most Wanted Men (1964), em que Warhol tentou estampar fotografias dos homens mais procurados pelo FBI na fachada do pavilhão americano da Feira Mundial. O gesto aqui é

\footnotetext{
${ }^{250}$ FOSTER, Hal. O retorno do real. Trad. Célia Euvaldo. São Paulo: Cosac Naify, 2014.p. 166.
} 
ambíguo. Aqueles são personagens também de um imaginário de paranoia e suspeição que toma os Estados Unidos desde o assassinato de John Kennedy. Por isso, o retrato daquelas pessoas revela tanto sentido de terror atribuído a elas, mas, também, de desejo, da curiosidade. Warhol se vale da ambiguidade de wanted, na língua inglesa, a significar tanto "procurados" como "desejados". Os personagens nas fotos, transferidos para a pintura, mostram-se problemáticos, perturbadores, instáveis. Mas eles são, mais do que qualquer coisa, imagens de um medo impalpável, na maioria dos casos, da encenação do horror da vida urbana.

Segundo Foster, a imagem trabalhada por Warhol oferece próteses de ego ${ }^{251}$ para os personagens retratados ou para as imagens capturadas em suas pinturas. O que parece mais forte, se derivarmos o raciocínio do autor, é que as imagens descrevem pavores paranoicos da sociedade americana que pairam pelos contemporâneos de Warhol, mas que não parecem ser necessariamente palpáveis. Embora o terror possa se consumar, ele provavelmente não acontecerá. Isso é relacionado com as paixões platônicas dos adolescentes por seus ídolos. Um desejo, uma devoção, um cuidado dos fã-clubes com a imagem. A relação do fã é com essa personificação imaterial. Warhol descreve esses afetos ansiosos da sociedade de consumo que não têm um objeto concreto, mas lidam com projeções fetichistas. Isso parece ganhar ambiguidade maior no momento em que Warhol decide não só se apropriar das imagens, mas registrá-las por sua conta.

\section{5.}

Em 1963, Warhol decide criar sua própria mitologia, seu próprio star system, suas próprias imagens. Ele se muda para o seu primeiro grande estúdio naquele ano e pensa nele não só como um ateliê, mas também como uma espécie de produtora do

\footnotetext{
${ }^{251}$ FOSTER, Hal. “Andy Warhol, or the distressed image”. Em The first pop age. Princeton: Princeton University Press, 2012. p. 162.
} 
cinema do entreguerras. Na primeira Factory começa a utilizar fotografias feitas por ele ou por seus assistentes em sua pintura, realiza trabalhos em fotografia, em cinema e, mais tarde, produz grupos de rock. Warhol tentava se comunicar como a rádio, a televisão e o cinema e prometia os efeitos da publicidade. A imagem é produzida, maquilada, artificiosa e artificial. Se seus trabalhos já perdiam a "semelhança com obras de arte", ${ }^{252}$ Warhol parece tentar produzir ele mesmo aquelas imagens da sedução, ver quando essas belezas e o cinema aparecem.

$\mathrm{O}$ artista frequentava as sessões de cinema experimental em Nova York desde 1961 e acompanha com entusiasmo a fundação do The New American Cinema Group, da Film-Makers' Cooperative. Warhol torce pelo sucesso da criação de um novo eixo de produção e distribuição de filmes sem relação com Hollywood e com o circuito de filmes convencional. Alguns dos seus interlocutores mais importantes, como Emile De Antonio e Jonas Mekas, estão firmemente envolvidos nesse movimento.

Interessado naquela produção, ele compra uma câmera Bolex em 1963 e passa a filmar compulsivamente. São desses primeiros anos algumas das fitas mais importantes de Warhol, começando com Sleep (1963), Kiss (1963), as três versões de Haircut (1963), e mais tarde Blow Job (1964) e Empire (1964). Embora a produção seja infinitamente maior $^{253}$ do que isso - só a série dos Screen Tests, feita entre 1964 e 1966, soma 472 títulos - nota-se que boa parte desses primeiros filmes silenciosos gravados em $16 \mathrm{~mm}$ compartilham as mesmas premissas técnicas e uma temática parecida.

Na época, Warhol se interessa pela produção cultural das vanguardas. Um pouco sem jeito, tenta mergulhar na efervescente e nova sociabilidade gay de Nova York. O meio não era só um gueto, converte-se em um dos vetores da produção cultural da

\footnotetext{
252 ADORNO, Theodor. Mínima Moralia.

${ }^{253}$ Disponível em: http://www.warholstars.org/andy_warhol_films.html. Acesso em: fev. 2017.
} 
cidade. Assim como ele se esforçava para ser aceito pelo meio de arte, tenta o mesmo esforço para adentrar na cena queer. Acompanha a produção e a vida das pessoas que circulam por lá e dialoga com as questões delas em seu trabalho.

Essa tentativa de escancarar desejos e gostos marginalizados aparece em um sem número de obras de arte da cidade nesse começo dos anos 1960; há produção afirmativamente gay nos filmes de Jack Smith e na seminal contribuição do Teatro do Ridículo de John Vaccaro e Ronald Tavel (que mais tarde ajudou Warhol nos filmes). As obras saídas daí são influência decisiva no trabalho de Warhol. Também o influenciará a vida noturna e, sobretudo, o modo como as drag queens e as travestis forjavam suas identidades seja por uma mudança cosmética, seja por uma mudança física. ${ }^{254}$

Em muitas dessas manifestações, transparece o gosto pelo que Susan Sontag chamou de camp: $:^{255}$ uma estética do artifício baseada muitas vezes no exagero sensual e em certa ambiguidade. Há um gosto ostentatório, carregado, que refaz as marcas de feminilidade icônica de maneira escancarada e desafiadora para a heteronormatividade. Em relação à Companhia de Teatro do Ridículo, o camp revela uma simulação mal disfarçada dos personagens e da estilização afetada e agressivamente afirmativa de hábitos marginalizados.

Os primeiros filmes de Andy Warhol estão em diálogo com essas manifestações culturais. Todos têm a forma do retrato: mesmo quando se registra um

\footnotetext{
${ }^{254}$ Warhol manifesta seu interesse por esses rapazes que se entendiam como moças e reconstruíam sua identidade a partir disso. Ele dá declarações sobre isso e se traveste em algumas polaroides. O esforço dessas garotas em esconder as suas marcas de masculinidade será descrito em sua Filosofia: "Entre outras coisas, as drag queens são testemunhos vivos do jeito como as mulheres queriam ser, o jeito como algumas pessoas ainda querem que elas sejam, e o jeito como algumas mulheres ainda gostariam de ser. As drags são arquivos vivos da feminilidade cinematográfica ideal. (...) Fico fascinado por rapazes que passam a vida tentando ser garotas completas porque eles têm que trabalhar tanto para se livrar de todos os traços masculinos e assimilar todos os traços femininos. (...) Drag queens são lembretes de que algumas estrelas ainda não são exatamente como você e eu". Em WARHOL, Andy. A filosofia de Andy Warhol. Rio de Janeiro. Cobogó, 2008. p. 69-70.

${ }^{255}$ SONTAG, Susan. "Notas sobre Camp". Em Contra a interpretação. Porto Alegre: L\&PM, 1987. p. 328.
} 
prédio, a forma do filme segue as mesmas convenções. A questão é o modo de retratar. Os negativos eram gravados com a câmera parada, presa em um tripé. Os planos são fechados e excessivamente iluminados. São filmes silenciosos em preto e branco. Como eram filmados em 24 quadros por segundo e exibidos a 16 quadros por segundo, parecem mais lentos do que o normal, mas não suficientemente lentos para notarmos um movimento antinatural. O procedimento isola a personagem no espaço e a trata como uma figura das pinturas de Warhol. No entanto, no caso dos filmes listados acima, existe uma relação diferente da pintura entre retrato e retratado.

Sleep (1963), Kiss (1963) e Blow Job (1964) têm sentido fortemente pornográfico e foram lidos nessa chave por muitos anos. No estudo pioneiro de Stephen Koch, Stargazer, sobre os filmes de Warhol, ${ }^{256}$ frequentemente o autor associa esses retratados a figuras típicas (por vezes estereotipadas) de um bas-fond marginal dos guetos gay de Nova York. Colocando a obra cinematográfica de Warhol próxima à literatura de Jean Genet, ela seria um retrato afirmativo de uma nova sociedade. Em sua descrição do importante filme Blow Job, Koch associa o personagem filmado à prostituição masculina, e diz que o foco da ação é excluído do frame. ${ }^{257}$ Para Koch, aqui se tem, como em várias de suas interpretações, a construção de tipos característicos da masculinidade novaiorquina do período. ${ }^{258}$

O filme é uma imagem de felação, onde supostamente o ator DeVerne Bookwalter recebe sexo oral. Não se sabia ao certo o que haveria de encenação ali e o que haveria de realidade. Em 2002, um dos mais importantes assistentes de Warhol, o poeta Gerard Malanga, disse que de fato se filmou um ato sexual explícito, mas isso não

\footnotetext{
${ }^{256} \mathrm{KOCH}$, Stephen. Stargazer: The life, world and films of Andy Warhol. Nova York: Marion Boyars, 1991. p. 42.

${ }^{257}$ Idem, p. 47.

${ }^{258}$ Douglas Crimp ataca essa associação por ver certo moralismo condescendente na análise de Koch.
} 
é isso o mais importante. O contexto do filme é revelador. Segundo Douglas Crimp, "Blow Job foi rodado em um período de vigilância policial do cinema underground". ${ }^{259}$ Filmes com referência à homossexualidade foram censurados e apreendidos. Segundo o autor, isso nos ajudaria a entender as escolhas do filme.

Nele, não vemos nenhum ato sexual acontecer, não vemos a interação entre corpos, só vemos um rosto com muita luz e muita sombra. Um rosto que mostra as suas reações diante do ato sexual. Mas a vista é parcial. A câmera filma de cima para baixo, a iluminação é forte e faz com que não vejamos nitidamente o personagem. Em algumas partes ele é excessivamente ofuscado, em outras, sombreado demais. O filme acontece em um forte claro-escuro. ${ }^{260}$ de fazer inveja ao mais grosseiro dos caravaggescos. Ao longo dos mais de trinta minutos do filme, e do crescente da excitação sexual, o rosto de um rapaz muda lentamente de expressão. A luz é tanta que o filmado, mesmo quando se dirige à câmera, o faz com dificuldade. Talvez por isso, ele não consiga manter a pose de retratado.

O ato sexual, quase como um dispositivo de retrato, impede que o ator interaja com a câmera de maneira mais franca. Impede também que ele faça pose. A excitação não o deixa preparar uma máscara para ser filmado. $\mathrm{O}$ ator estica o pescoço, fecha os olhos, entorta a boca. Quando o ato sexual termina, ele tenta nos encarar, mas o sombreado denso esconde seus olhos do espectador. ${ }^{261} \mathrm{O}$ personagem acende um cigarro e vai desaparecendo na sombra e na fumaça. A persona não é construída na imagem.

\footnotetext{
${ }^{259}$ CRIMP, Douglas. Our Kind of Movie: The Films of Andy Warhol. Cambridge: MIT Press, 2012. p. 3. ${ }^{260}$ GIDAL, Peter. Blow Job. Londres: Afterall Books, 2008. p. 15.

${ }^{261}$ Douglas Crimp afirma que os olhares do ator nunca são para o público, compara com outros filmes mais deliberadamente encenados de Warhol, como os dois Mario Banana, e diz que aqui os olhares não são direcionados ao público. Cf. CRIMP, Douglas. Our Kind of Movie: The Films of Andy Warhol. Cambridge: MIT Press, 2012.
} 
É evidente que o filme, mesmo que não registre o ato, tem sentido erótico explícito. Também como os outros filmes silenciosos mencionados. Blow Job diz respeito a um desejo violentamente reprimido e recusado socialmente. O personagem não se revela em grande medida por essa violência e, como acusa Douglas Crimp, em seu ótimo estudo sobre a relação do cinema de Warhol com o meio social gay de Nova York, de alguma maneira o filme responde à homofobia da censura em Nova York escondendo o que os policiais queriam ver por uma razão ou outra. ${ }^{262}$

O que parece mais interessante nessa espécie de retrato é a dificuldade de o personagem personificar qualquer autoprojeção. Diferente da tradição do retrato, aqui o personagem não é construído como alguém reconhecível. Não se tem uma imagem final do retratado. Ele tenta, mas o ombro cai, o olho sente a luz forte e a autoconstrução da imagem não é possível. Ele não se deixa ver direito e é errado caracterizá-lo, como Stephen Koch faz. Sleep, Kiss, Empire são filmes em que os retratados estão em uma posição em que não conseguem manter a encenação de sua persona.

Warhol parece impor dificuldades para poses e caras e bocas nesses seus primeiros filmes. Em todos, algum tipo de dispositivo impede o filmado de simular uma face mais sedutora, piedosa, convincente. Em Kiss, os personagens estão compenetrados em sua ação, se beijando, sem olhar para a câmera. Em Sleep, primeiro filme de Warhol, John Giorno, colaborador frequente de Warhol, dorme por mais de cinco horas. E o prédio projetado de Empire não mostra vida, relação com a cidade ou com a câmera. É o ícone

\footnotetext{
${ }^{262}$ Crimp narra a apreensão e censura do filme Flaming Creatures, de Jack Smith, e a violenta repressão a expressões culturais abertamente gays em Nova York na época. Essa agressividade queer do Teatro do Ridículo, por exemplo, será decisiva para a formação do proto-punk nova-iorquino de Velvet Underground e do New York Dolls. CRIMP, Douglas. Our Kind of Movie: The Films of Andy Warhol. Cambridge: MIT Press, 2012.
} 
impassível da cidade de Nova York, dos Estados Unidos da América. Com Blow Job não é diferente.

Nos diferentes Screen tests, os retratados tentam encarnar essa projeção de si mesmos. Os filmes são testes de câmera com a duração de um rolo, filmados entre 1964 e 1966. Warhol fez centenas deles, registrava todos que passavam por ele e os resultados são muito variados. Contudo, eles foram muito pouco mostrados até os anos 1980, depois da morte de Warhol. Alguns foram exibidos no show do Velvet Underground: Exploding Plastic Inevitable; outros foram mostrados na Film-Makers Cooperative e na Europa, em projetos como Os mais lindos rapazes e As mais lindas moças. ${ }^{263}$ A maior especialista nos filmes de Warhol, Callie Angell, afirma que ele fez muitos testes de câmera, mas por pouco tempo. Em 1966, o artista se desinteressa, deixa de fazer os testes, dando maior atenção para filmes sonorizados, como Chelsea Girls. ${ }^{264}$ Mas até então, ele pensava ter encontrado um dispositivo que fazia as pessoas simularem mitos.

Apoiando-me na descrição dos filmes de Andy Warhol feita por Douglas Crimp, ${ }^{265}$ vejo como essa fragilidade da encenação dos personagens nos Screen Tests foi rica para o artista. Por mais curtos que sejam os filmes, não é fácil para quem está sendo filmado manter a pose que o modo de encarar a câmera parece exigir. Filmava-se com uma câmera exageradamente próxima do retratado, com uma iluminação desagradavelmente forte.

Os personagens dos Screen Tests se esforçam para manter a postura. Dificilmente alguma coisa não os distrai da sua encenação. São “atores”, entram e saem do "papel” o tempo todo. Por essa e outras razões, Crimp rejeita a classificação dos filmes

\footnotetext{
263 ANGELL, Callie. Andy Warhol Screen Tests. The Films of Andy Warhol Catalogue Raisonée. 319 pp. New York: Harry N. Abrams Inc., 2006. p. 19. 264 Idem.

${ }^{265}$ CRIMP, Douglas. Our Kind of Movie: The Films of Andy Warhol. Cambridge: MIT Press, 2012.
} 
de Warhol como voyeuristas e exibicionistas. ${ }^{266}$ Para Crimp, a câmera não pega ninguém desprevenido, como um voyeur, nem revela uma natureza real de quem se mostra. Nos filmes há verdade, mas de outra natureza. “O conhecimento de um mundo que seus filmes [de Warhol] nos oferece não é um conhecimento do outro para o eu. Em vez disso o que eu vejo é um performer no momento de ser exposto de tal forma que ele se torna, como Warhol disse, tão verdadeiro". ${ }^{267}$ É o momento em que a promessa de sucesso não se realiza; em que a imagem se mostra inconciliável com a vida.

Segundo Hal Foster, as imagens que Warhol produziu nos filmes são testemunhos desse desencontro entre o real e o projetado: "Cada Screen Test é um desencontro (...) em certo sentido, os Screen tests dão um rosto (muitos rostos) para os automatismos perturbadoras sondados lá -, porém, é difícil dizer se esse rosto faz os automatismos parecer mais humanos ou nós humanos mais automáticos". ${ }^{268}$ Nesses filmes, os filmados tentam manter a pose, mas são traídos pelas circunstâncias o tempo todo. Os gestos tornam-se impossíveis.

As imagens dos Screen Tests nunca são o sucedâneo de quem é filmado, tampouco a mais perfeita encenação. Ficam entre uma coisa e outra. A imagem parece ter vida curta. Por melhor que a encenação seja, a promessa de alegria dessas réplicas de luz da vida são alegrias passageiras. Aqui, o artista se dedica a buscar uma imagem ordinária, em construir personagens convencionais. Seu trabalho está a léguas de distância da aparência da arte, mas essa ambiguidade é potente.

\footnotetext{
${ }^{266}$ Idem, p. 8.

${ }^{267}$ CRIMP, Douglas. Our Kind of Movie: The Films of Andy Warhol. Cambridge: MIT Press, 2012. p. 36. Uso o termo na falta de tradução melhor para "so for realness".

${ }^{268}$ FOSTER, Hal. “Andy Warhol, or the distressed image”. Em The first pop age. Princeton: Princeton University Press, 2012. p. 169.
} 
Mesmo em filmes mais complicados, enclausurados, compostos como Chelsea Girls e Poor Little Rich Girl há essa dificuldade de a personagem se encontrar com suas aspirações. Quando os atores querem se converter em estereótipo, eles parecem não conseguir completamente. Nem mesmo quando querem se portar naturalmente, isso parece possível.

As imagens aqui mostram as pessoas encenando papeis marcados pelos valores daquela sociedade; como a fama e o glamour. É um momento nos Estados Unidos em que qualquer possibilidade de transformação mais radical da vida - a criação do novo, da redenção, da emancipação - começa a ficar fora de cogitação. Resta explorar aspectos quebrados de uma subjetividade que não promete grande coisa. Aliás, Warhol os explora. Depois de 1966, tenta promover artistas, publica revistas, participa de programas de televisão e torna-se uma máquina publicitária de si mesmo. Sua pintura sofre com isso por um tempo. Alguns dos retratos que o artista faz nos anos 1970 confundem o que era o abrir mão de um estilo com uma assinatura. Assim, as imagens ordinárias, esvaziadas, passam a ser valorizadas pelo "toque Andy Warhol" que existe nelas. Mas o artista foi quem levou mais a sério as promessas da indústria cultural e suas desilusões. Embora não fosse um crítico dessa lógica, aliás, estava a ela totalmente integrado, mostra a nós um olhar resignado e melancólico. Seus melhores trabalhos parecem dizer: É isso que temos.

Warhol explora as possibilidades diante de um profundo vazio de alternativas históricas. Os personagens que as imagens, e ele mesmo, encenam não parecem existir plenamente no nosso mundo. Não têm grandeza heroica nem carregam o sofrimento da tragédia, são figuras que do outro lado do espelho preservam momentos supostamente grandiosos, emocionantes. 
É como se Warhol só conseguisse se referir às formas narrativas a partir de um universo integralmente colonizado pela cultura de consumo. A imagem aqui, embora não substitua a natureza, a vida, é o único lugar em que as pessoas encontram qualquer tipo de excitação. Mas a duração da pose é curta, dura um clique. As imagens ficam como lembranças de expectativas miúdas diante de uma vida que não muda tanto, mesmo quando fingimos ser outros.

A imagem de Warhol não promove uma reconciliação com o real. Os ícones pintados, seja Marilyn Monroe, seja a cadeira elétrica que matou os Rosenberg, nos fazem procurar o referente que estaria por trás deles. Alguma coisa está ali, mas é inacessível a nós. Mesmo que exista algum resíduo de personalidade por trás daqueles ícones, provavelmente se trata de pedaço morto.

Nos Screen Tests, os personagens tentam manter a pose, tentam manter a face, mas perdem $\operatorname{logo}$ depois. Aliás, esses filmes se arrastam; os personagens estão enclausurados, matando o tempo, sem esperar ansiosamente por nada. $\mathrm{Na}$ estética resignada do diretor Warhol, a vida já promete pouco. Pode-se ter a sorte de comer a mesma refeição todos os dias, ser convidado para uma festa, escutar uma música que traz boas lembranças no rádio, ficar famoso e ser adorado como ídolo - mesmo que o ídolo não se confunda totalmente com a pessoa. No entanto, mesmo essas promessas de diamantes, casacos de pele e champanhe não são cumpridas. Os personagens nos filmes tentam com ou sem artifícios mostrar um momento gracioso da vida, que se esvai em um átimo. 


\section{CAPÍTULO 3}

Por isso minha voz esconde outra

Que em suas dobras desenvolve outra

Onde em forma de som perdeu-se o canto Que eu sei aonde mas não ouço ouvir ${ }^{269}$

(AUGUSTO DE CAMPOS)

269 Última estrofe do poema O rei menos o reino (1950), de Augusto de Campos. Foi publicado em 1951, no livro de estreia do poeta, que leva o mesmo nome do poema. 


\section{Fotografia e convenção}

Nos capítulos anteriores, foram descritos episódios da história da arte em que artistas começaram a produzir a partir de linguagens de outros campos da produção visual. Muitas vezes, eles abriram mão da especificidade do artístico, diluindo-se no mundo das outras formas de criação de imagem. O caso exemplar de Warhol, e da pop, é trabalhar a partir das linguagens do consumo e, inclusive, perceber o quanto a reflexão culta também passa a fazer parte de um circuito produtivo da cultura de massa.

Gerhard Richter também lida com esses novos meios de produção de imagem. Seus trabalhos de 1962 aproveitam imagens de colunas sociais, jornais, revistas, publicidade. A sua formação, no entanto, leva-o a aproximar esses modos de composição da cultura comercial de linguagens convencionais da história da arte. Interessa-se pelo sentido ideológico daquelas maneiras de dispor as figuras. A cultura de consumo, no entanto, não desperta grande curiosidade no artista.

O pintor busca algum significado propriamente artístico em uma sociedade totalmente colonizada pela hiperexposição da propaganda, dos noticiários e das memórias das fotografias domésticas.

\section{Fotopintura ${ }^{270}$}

Gerhard Richter descobre o uso artístico de imagens fotográficas na pintura quando entra em contato com a obra dos artistas norte-americanos. Conhece primeiro o trabalho de Rauschenberg. Interessa-se por suas colagens, em razão de uma espécie de dessacralização que o artista faz do gesto da pintura abstrata informal americana e uma aproximação entre as linguagens do modernismo e o imaginário documental das

\footnotetext{
${ }^{270}$ Richter chama as imagens fotográficas recriadas em tela de fotopinturas desde 1964.
} 
fotografias. Contudo, Richter só começa a copiar fotografias com tinta e pincel após conhecer as obras de Roy Lichtenstein, Claes Oldenburg e Andy Warhol; após o seu contato com a pop art.

Antes disso, o artista alemão já se interessava pelo trabalho figurativo de artistas como Francis Bacon, ${ }^{271}$ Jean Dubuffet ${ }^{272}$ e Alberto Giacometti. ${ }^{273}$ A curiosidade àquela altura tinha pouco a ver com qualquer investigação da imagem fotográfica. O que lhe enchia os olhos era o tom dramático daqueles quadros, expresso por manchas que mal cabiam nos contornos, mostrando um corpo disforme e dolorido.

Richter estudava as figuras que perdiam seus contornos, massas que perdiam a estabilidade. Via nessa relação entre matéria e forma, uma espécie de perturbação. Tais trabalhos lhe despertavam a mesma curiosidade que a pintura abstrata de Fautrier, Fontana e Burri. Tratava-se da pintura que sobrava depois que a matéria corroía a forma.

Segundo Dietmar Elger, o primeiro trabalho de fotopintura pode ter sido Festa (1962). ${ }^{274}$ Ao menos, foi uma das poucas pinturas daquela época que não foram destruídas por Richter. ${ }^{275}$ A tela ainda é bastante influenciada por Francis Bacon, pelo neodadaísmo e por Lucio Fontana. Traz a visão dolorida da pintura de Bacon, a subversão do sentido das manchas e gestos de Rauschenberg e o entalhe da superfície de Fontana.

\footnotetext{
${ }^{271}$ ELGER, Dietmar. Gerhard Richter: A Life in Painting. Chicago: University of Chicago Press, 2010. p. 44. ${ }^{272}$ Idem.

${ }^{273}$ RICHTER, Gerhard. "Work Overview, 1968”. Em ELGER, Dietmar; OBRIST, Hans Ulrich. Gerhard Richter. Text: Writings, Interviews and Letters. Londres: Thames \& Hudson, 2009. p. 48.

${ }^{274}$ ELGER, Dietmar. Gerhard Richter: A Life in Painting. Chicago: University of Chicago Press, 2010. p. 41.

${ }^{275}$ No seu Catalogue Raisonée, Richter numera como primeiro trabalho Mesa (Tisch), de 1962. A ordem de seu catálogo é peculiar. $\mathrm{O}$ artista refaz sua trajetória nele, elimina tudo que considera irrelevante, comprando e escondendo ou destruindo obras que não lhe interessam e estabelecendo uma hierarquia que por vezes não segue a ordem cronológica. Ele estabelece uma ordem de desenvolvimento das suas ideias e séries. Idem, p. 48.
} 
A pintura foi feita a partir de uma fotografia de coluna social, em que o apresentador italiano Vico Torriani aparece risonho em uma festa de gala rodeado por mulheres elegantes. Torriani é apresentado no meio do quadro, como centro das atenções. Ele e as mulheres seguram canecas. É um dos temas mais pop que Richter pintou. No entanto, o tratamento não é pop. Mais de uma vez, Richter disse que ali ele havia pintado demais. Embora ele copie a fotografia, intervém e comenta bastante suas impressões da futilidade da alta sociedade. É uma pintura de recusa moral.

Richter rasga a lona, insere manchas vermelhas vampirescas nos rostos, nos braços e nas pernas dos personagens, faz com que os talhos se comportem como cicatrizes, atribui cor à perna de uma das figuras, fazendo com que aquele membro não componha uma unidade com o resto do corpo. Aqui a fotografia de coluna social é desafiada por certa busca da verdade. Um mundo além das aparências.

O artista, ao intervir de maneira tão decidida e violenta - talvez com a mão um tanto pesada -, faz o seu primeiro diagnóstico da imagem fotográfica. Ele não a vê como uma representação cristalina do real, mas um meio que turva a visão. Nessa tela especificamente, o glamour não é visto, tal qual em Warhol, como felicidade possível. É uma farsa. É interessante que a forma de chegar à verdade é pelo esgarçamento, como nos artistas abstratos informais de que Richter gostava.

O estudo feito por Richter das obras pop americanas, na mesma época, o faz mais fiel aos seus motivos. Aos poucos, abandona esse carregado comentário moral das fotografias, das figuras pop, e busca uma representação neutra das imagens. A fotografia que vai lhe interessar é a menos encenada e discursiva possível. Em outras palavras, é a imagem comum. Uma imagem que quando vista é prontamente identificada como uma reportagem, um retrato, uma cena de família. Tudo figurado da forma mais inocente e vernacular; menos estilizada possível, 
O glamour definitivamente não é um assunto de sua pintura. Embora a fotografia ainda mantenha esse sentido turvo, de dificuldade de encontro com a realidade que ela mesma indica, o artista se interessará cada vez mais por formas cada vez mais anônimas desse tipo de apresentação. Como o próprio Elger ressalta, Richter nunca se viu como um artista pop exatamente. ${ }^{276}$

O pintor entrou em contato direto com a arte moderna tardiamente. Formado no ambiente tradicionalista do realismo socialista de Dresden, então na Alemanha Oriental, estudou pintura figurativa tradicional. A escola era pouco mais flexível do que o seu correlato soviético, mas ainda assim bastante estrita. ${ }^{277}$ Parte do aprendizado era copiar obras-primas do museu de Dresden. Alguns temas extraídos das pinturas da coleção ainda são recorrentes em seu trabalho.

Em 1955, Richter vê exposições de arte moderna pela primeira vez. Já conhecia alguma coisa: obras de artistas de vanguarda ligados ao Partido Comunista, ${ }^{278}$ imagens vistas em revistas do ocidente, o modernismo pouco radical tolerado, e até mesmo incentivado, pelo regime em seus primeiros anos. ${ }^{279}$ Tudo muito tímido.

$\mathrm{O}$ artista entra em contato com as vanguardas do pós-guerra em geral, e com a pintura abstrata em particular, depois de suas viagens para fora da zona de influência soviética a partir de 1955. Em 1957, privadamente, ele começa a ensaiar uma linguagem moderna (105 e 106). Mas só dois anos mais tarde, depois de uma visita à II Documenta de Kassel, em 1959, esse gosto começa a ganhar sentido estético. É quando Richter conhece o trabalho de Lucio Fontana e de Jackson Pollock, decisivos para o seu trabalho

\footnotetext{
${ }^{276}$ Idem, p. 46.

277 CURLEY, John J. A Conspiracy of Images. New Haven/Londres: Yale University Press, 2013. p. 85.

${ }^{278} \mathrm{O}$ nome mais influente era o de Pablo Picasso, copiado por Richter em seus primeiros anos. Cf.

CURLEY, John J. A Conspiracy of Images. New Haven/Londres: Yale University Press, 2013. p. 88.

${ }^{279}$ ELGER, Dietmar. Gerhard Richter: A Life in Painting. Chicago: University of Chicago Press, 2010. p. 95-96.
} 
até hoje. Chama-lhe a atenção o modo como os artistas trabalham a superfície, de maneira matérica, densa. Richter identifica certo esgarçamento, seja da estrutura, seja do suporte, seja da forma. Ali, ele vê uma pintura ácida, a se deformar.

Em suas monotipias em nanquim, de 1957 (105 e 106), são perceptíveis algumas das questões que ele percebe nesses artistas e que permaneceram em seu trabalho por todo o tempo. Ele lê a abstração como uma figuração em apagamento. Os gestos desfazem o que o artista havia antevisto.

Quando ele foge para a Alemanha Ocidental, em 1961, tem a produção desses artistas na cabeça. Interpreta a produção moderna como a negação ao tipo de pintura convencional, literária e propagandística que ele fazia nos murais de Dresden. ${ }^{280}$ A pintura gestual abstrata para ele, em um primeiro momento, evitava toda convicção retórica dos trabalhos propagandísticos de tipo soviético. Richter encontrava nessa forma de pintar algum tipo de experiência genuína com a arte.

Para o Richter muralista de Dresden, a abstração gestual não é só a construção de uma nova espacialidade, de um novo uso para cores, formas e manchas, mas a destruição da representação tradicional. Até 1962, ele vê a abstração gestual, com que ele entrara em contato há poucos anos, como uma produção de recusa. Uma forma de expressão onde as linguagens tradicionais são desfeitas em nome de uma experiência estética arrebatadora, descontrolada e verdadeira. Uma negação determinada, em busca de uma relação mais franca com a arte, para além dos modelos dados.

\footnotetext{
${ }^{280}$ Cf. CURLEY, John J. A Conspiracy of Images. New Haven/Londres: Yale University Press, 2013. p.
} 84-92. 
Não por acaso, logo que ele se exila em Dusseldorf, em 1961, irá se identificar com o espírito histórico do Dada ${ }^{281}$ e do grupo Fluxus. ${ }^{282} \mathrm{O}$ interesse pela prática desses grupos passa pela procura de uma ação artística niilista, ${ }^{283}$ antiartística. ${ }^{284}$. Aliás, nos primeiros anos, Richter não faz só pintura exatamente. Também se dedica a happenings e, em alguma medida, à antiarte.

A abstração é aproximada desse ethos destrutivo, niilista, de eliminação de todas as convenções, de todas as imagens reconhecíveis, qualquer mensagem e qualquer promessa ideológica. ${ }^{285}$ A arte é um lugar da dissolução de certezas, ao contrário do que ele fazia na Alemanha Oriental: uma produção visual de reafirmação de convicções convencionais. As promessas ideológicas, para Richter, estariam ligadas intimamente a essa convicção propagandística do uso da imagem como meio para transmitir uma mensagem. ${ }^{286}$

\footnotetext{
${ }^{281}$ De acordo com Robert Storr, o interesse de Richter pelo dadaísmo é despertado pela obra de Robert Rauschenberg. Embora alemão, Richter vai entrar em contato com a obra de Kurt Schwitters por intermédio de um artista dos Estados Unidos. Cf. STORR, Robert. Gerhard Richter: Forty years of painting. Nova York: The Museum of Modern Art, 2002. p. 25.

${ }^{282}$ Idem, p. 26. Em 1964, Richter conta: "Quando eu estudei com [Karl Otto] Götz em Dusseldorf, em 1961 (logo que me mudei para o ocidente), eu era muito confuso, desesperado para começar alguma coisa. O que me libertou eventualmente foi o encontro com Fluxus e a Pop Art". RICHTER, Gerhard. "Notes, 1964". Em ELGER, Dietmar; OBRIST, Hans Ulrich. Gerhard Richter. Text: Writings, Interviews and Letters. Londres: Thames And Hudson, 2009. p. 21.

${ }^{283}$ Idem, p. 375.

${ }^{284}$ Cf. RICHTER, Gerhard. "Interview with Jan Thorn-Prikker, 2004”. Em ELGER, Dietmar; OBRIST, Hans Ulrich. Gerhard Richter. Text: Writings, Interviews and Letters. Londres: Thames \& Hudson, 2009. p. 475.

${ }^{285}$ Richter não trabalha com ideologia como um conceito preciso, mas como uma noção sempre evocada por ele para marcar seu antagonista. Ele desenvolve a ideia de maneira nietzschiana, mais ou menos como Nietzsche desenvolve a ideia de "pensamento dogmático" e "vontade de verdade" em Além do bem e do mal. Richter vê a ideologia como a doutrina do "pensamento dogmático". O estabelecimento de uma ordem causal simples para a história que nos garantiria uma promessa de vida melhor mediante alguns compromissos. Como ele mesmo afirma em 1989, "Eu não sei: talvez meu ódio à ideologia esteja enganado, talvez eu esteja confundindo uma coisa com outra. Porque, quando falo: "acredito que amanhã teremos um bom clima", isso envolve alguma medida de crença e ilusão. Mesmo assim, considero as crenças de todos os tipos, desde a astrologia até toda religião elevada e todas as grandes ideologias, supérfluas e fatalmente perigosas. Não precisamos mais de tais coisas. Devemos elaborar diferentes estratégias contra a miséria e as injustiças, a guerra e as catástrofes". Cf. RICHTER, Gerhard: "Interview with Jan Thorn-Prikker, 1989”. Em ELGER, Dietmar; OBRIST, Hans Ulrich. Gerhard Richter. Text: Writings, Interviews and Letters. Londres: Thames \& Hudson, 2009. p. 239.

${ }^{286}$ Quando perguntaram para Richter, em 2000, se havia alguma "mensagem" em suas pinturas, ele respondeu: "Não há mensagem alguma, somente a esperança de que a vida pode ser bela". Citado em
} 
Por isso, ele identificará o realismo socialista com o imaginário da sociedade de consumo e, mais que isso, com uma retórica de libertação implicada em certos discursos a respeito da arte moderna. A linguagem dessas formas de convencimento estético é associada à publicidade, a certa estandardização da sociedade.

Tais simplificações nos distanciariam de um contato mais genuíno e direto com o mundo. Richter chamará essas promessas convictas de libertação, muitas vezes equiparadas a sua experiência com o nazismo, de ideologia. ${ }^{287}$ Quando perguntado sobre a razão de se afastar de certo "modernismo dogmático", Richter afirma:

Talvez eu tenha uma espécie de imunidade a ideologias e modas, pois sempre passei longe dos movimentos: a religiosidade da casa dos meus pais, o nazismo, o socialismo, o rock - e todas as outras modas que foram o máximo em ideologia, comportamento, moda cabelos e tudo o mais. Para mim tudo isso parecia mais intimidante do que atraente. ${ }^{288}$

Embora Richter admirasse a complexidade compositiva de artistas abstratos, como Pollock e Dubuffet, ${ }^{289}$ ele identifica nesses artistas uma tradução dessa dissolução das formas tradicionais. Uma dissolução violenta, ácida. De certa maneira, a arte passa a

FOSTER, Hal. "Gerhard Richter, or the photogenic image". Em The First Pop Age. Princeton: Princeton University Press, 2012. p. 205.

Sobre a mensagem em arte, Richter também disse em 1986: "As mensagens dos pintores são sempre angustiantes, chatas, mentirosas, atabalhoadas, abjetas e agressivas". RICHTER, Gerhard. "Notes, 1986". Em ELGER, Dietmar; OBRIST, Hans Ulrich. Gerhard Richter. Text: Writings, Interviews and Letters. Londres: Thames \& Hudson, 2009. p. 160.

${ }^{287}$ RICHTER, Gerhard. "From a letter to Benjamin Buchloh, 29 september, 1977". Em ELGER, Dietmar; OBRIST, Hans Ulrich. Gerhard Richter. Text: Writings, Interviews and Letters. Londres: Thames \& Hudson, 2009. p. 103.

${ }^{288}$ OBRIST, Hans Ulrich. "Gerhard Richter”. Em Entrevistas. v. 1. Rio de Janeiro: Cobogó/Belo Horizonte: Inhotim, 2009. p. 143.

${ }^{289}$ De alguma maneira, o caráter antirrepresentativo da primeira pintura abstrata de Richter parece ecoar algumas ideias do Grupo Zero. O grupo foi fundado por artistas de Dusseldorf, como Otto Piene, Heinz Mack e Gunther Ücker, com quem Richter conviveu e por vezes trabalhou. Richter admirava esses artistas. O caráter objetual dos trabalhos aproxima-os, embora Richter não compartilhe do aspecto idealista, utópico, inaugural de uma nova realidade daqueles artistas. 
ser entendida por Richter como uma busca por algum tipo de experiência genuína possível.

O pintor pretende remover a carga de significados caducos, de conotações ideológicas, de referências idealizadas à vida para chegar a uma experiência autêntica e poética. Esses significados atrelados a convenções, apropriados pelo kitsch, pelo reino das imagens, pelas promessas modernistas do estilo tenderiam a tornar nossa relação com o conteúdo poético insípida. ${ }^{290}$

Isso o faz problematizar até mesmo a arte e suas distinções. $\mathrm{O}$ curioso é que não se trata de um interesse em promover o não artístico ao status de arte, mas de ver quão enfadonhos os significados de arte podem ser. Ou seja, de rebaixar os sentidos da arte elevada à vulgaridade das representações visuais mais esquemáticas. O seu interesse pela fotografia doméstica, jornalística, sem cuidado artístico, passa por essa busca de uma relação da arte mais próxima do mundo, embora avessa à ideia de fusão entre arte e vida.

Essa relação disruptiva traz a sua obra um interesse profundo pelas convenções, pelas formas de representação. A partir de 1962, o artista mergulha em formas absolutamente reconhecíveis de representação, próximas da figuração pop e neorrealista. Mas ele identifica nessa produção não a chance de pintar produto, mas de pensar essas imagens ordinárias como pintura. Ele começa a pintar as fotografias a procura de uma representação menos estilizada, mais direta, com uma carga maior de informação do que de composição.

Tendo isso em mente, começa-se a entender a diferença de interesse pela imagem técnica, pela imagem mecanicamente capturada, no trabalho de Gerhard Richter

\footnotetext{
${ }^{290}$ RICHTER, Gerhard. "Letter to Werner Schimidt,1990”. em ELGER, Dietmar; OBRIST, Hans Ulrich.
} Gerhard Richter. Text: Writings, Interviews and Letters. Londres: Thames \& Hudson, 2009, p. 249. 
e na pop dos Estados Unidos, especialmente no trabalho de Andy Warhol. Embora ambos entendam a fotografia como uma apresentação indireta do mundo, Warhol vê tanto nas fotografias de celebridades, quanto nas fotografias de acontecimentos impactantes, uma conversão do banal em espetáculo, uma possibilidade de encontro mediado, como prefere Hal Foster, um encontro traumático ${ }^{291}$ com aqueles personagens e eventos que parecem inatingíveis nas fotografias. É esse mundo da idolatria que interessa ao artista pop americano, um tipo de iconofilia. Ele vê nessas imagens algo mais excitante e glamouroso do que a vida tal como ela é vivida. Muito diferente do pintor alemão, que estava mais interessado no caráter ordinário e irrefletido das fotos.

Richter não se interessa pelas fotografias de famosos. Seus personagens não são ídolos pop, figuras inatingíveis. Quando reconhecíveis, tal como Jaqueline Kennedy (113) e Andreas Baader (79 e 80), o artista busca despersonalizá-los quando os pinta. Não os escolhe por sua notoriedade, mas para que se tornem irreconhecíveis. Nas pinturas, Baader surge desfigurado, como carne morta, convertendo-se em mancha. ${ }^{292}$ Sua Jackie Kennedy olha para baixo, esconde o rosto e não é identificada nem na legenda. $\mathrm{O}$ artista desfoca a imagem na tela, faz com que o nosso contato se torne mais indireto com a memória que aquelas imagens poderiam nos despertar.

A fotografia não torna nada mais excitante, como em Warhol. Richter assume a fotografia não como ícone, mas em sua dimensão documental. ${ }^{293}$ As pinturas, muitas vezes chamadas de "imagem", mesmo quando abstratas. ${ }^{294}$ não se assemelham a produtos

\footnotetext{
${ }^{291}$ Warhol vai se referir àquelas imagens como "meia-dimensão". Em WARHOL, Andy. A filosofia de Andy Warhol. Rio de Janeiro: Cobogó, 2008. p. 79.

292 Richter mostra duas imagens de Andreas Baader na série 18 de outubro de 1977. As duas telas têm o mesmo tamanho. Em uma a figura é mais sombreada, escurecida e sólida. Em outra, os contornos se desmancham, a carne vira um cinza claro, quase branco, e as formas parecem se desfazer, diluindo os contornos.

${ }^{293}$ ELGER, Dietmar. Gerhard Richter: A Life in Painting. Chicago: University of Chicago Press, 2010. p. 192.

${ }^{294}$ É importante lembrar aqui que, embora o discurso escrito e falado do artista seja muito vacilante, ele mantém alguns termos. Ele diz falar dos seus trabalhos mais como "pictures", como um termo mais
} 
ordinários, tampouco mostram-se banais; Richter não demonstra o mínimo interesse na banalidade. ${ }^{295}$ Segundo Armin Zweite, as fotografias - pelo menos nos trabalhos até 1976, quando a abstração se torna dominante em sua obra - não funcionam apenas pelo que informam ou pela estrutura; elas seriam uma espécie de catalisadores, pensadas para ser manipuladas pelo gesto artístico. ${ }^{296}$

Segundo a cronologia do catálogo da exposição Panorama, de $2011,{ }^{297}$ ele viu as pinturas de Warhol pela primeira vez em 1963, na Galeria Sonnabend, e elas provocaram nele profundo interesse. ${ }^{298} \mathrm{O}$ artista tem posições relativamente ambíguas sobre Warhol, ${ }^{299}$ como sobre muitas outras coisas, no entanto o reconhecimento da influência é inequívoco.

Em mais de uma declaração, ele já afirmou a centralidade das serigrafias de Warhol. ${ }^{300}$ Mesmo que diga ver interesse mais cultural que artístico nelas, elas provocaram uma inflexão em seu trabalho. O curioso é como essa reflexão em torno da imagem, fez aparecer uma pintura inteiramente diferente da feita por Warhol, muitas vezes mais comprometida com a ideia moderna de obra e de pintura - ao menos com a tentativa de preservação de alguma pintura em um sentido mais tradicional.

\footnotetext{
genérico de imagem, do que em "paintings". Para o artista, a palavra alemã Bild carregaria ambiguidade maior do que malerei. Cf. RICHTER, Gerhard. "From a letter to Benjamin Buchloh". Em ELGER, Dietmar; OBRIST, Hans Ulrich. Gerhard Richter. Text: Writings, Interviews and Letters. Londres: Thames \& Hudson, 2009. p. 93; e OSBORNE, Peter. "Abstract images: image, sign and aesthetician Gerhard Richter's painting”. Em BUCHLOH, Benjamin H. D (Org.) Gerhard Richter (October Files). Cambridge: MIT Press, 2009. p. 98.

295 "Isto é importante, o que pinto não pode ser banal". Em ELGER, Dietmar; OBRIST, Hans Ulrich. Gerhard Richter. Text: Writings, Interviews and Letters. Londres: Thames \& Hudson, 2009. p. 43. ${ }^{296}$ ZWEITE, Armin. "Gerhard Richter's album of photographs, collages and sketches". Em BLAZWICK, Iwana; GRAHAM, Janna. Atlas: the reader. Londres: Whitechapel Gallery, 2004. p. 37.

${ }^{297}$ GODFREY, Mark; SEROTA, Nicholas. Gerhard Richter: Panorama. Londres: Tate, 2011. p. 283.

${ }^{298}$ Cf. entrevistas de 1972 e 1978 reproduzidas nas páginas 68 e 11 do livro ELGER, Dietmar; OBRIST, Hans Ulrich. Gerhard Richter. Text: Writings, Interviews and Letters. Londres: Thames \& Hudson, 2009. ${ }^{299}$ Hal Foster, no texto "Gerhard Richter, or the photogenic image", desenvolve essa posição oscilante de Richter sobre Warhol. Em FOSTER, Hal. "Gerhard Richter, or the photogenic image". Em The First Pop Age. Princeton: Princeton University Press, 2012.

${ }^{300} \mathrm{Hal}$ Foster parodia Adorno e diz que "Richter se pergunta se é possível pintura lírica depois de Warhol". Idem, p.175.
} 
Warhol e Richter desenvolvem concepções muito distintas ao relacionarem pintura com imagem fotográfica. Warhol usou técnicas gráficas para fazer sua pintura. Ela é mecânica, feita da transferência de imagem para a tela. A imagem entra lá como entraria em qualquer superfície, é quase como a alocação de um objeto em uma prateleira. As imagens distribuídas serialmente não têm relações necessárias, relacionam-se por proximidade. Como Donald Judd desenvolveria sobre o seu próprio trabalho anos mais tarde, aqui se trata de "uma coisa depois da outra". 301

Richter vai em outra direção, tudo ali é pintura. Embora ele imite imagens fotográficas quaisquer, elas são reconstruídas com tinta e pincel. A imagem, no mais das vezes, é íntegra, feita não de repetição de clichês, mas de uma unidade que relaciona um elemento com outro no espaço ilusório. Ele é quem melhor explica a diferença entre um procedimento e outro. Em 1991, comentando a sua pintura Mulher com guarda-chuva (1964) (113), o pintor alemão se contrapõe a Warhol. Vê diferenças na composição, no sentido da imagem e até mesmo no modo como o mesmo tema (Jaqueline Kennedy) é organizado nos trabalhos dos dois artistas. Para Richter:

As pinturas de Warhol tratam a imagem de tal forma que é possível imaginá-la continuando indefinidamente para além das laterais da tela. Na minha pintura a grande margem gráfica separa a imagem, no interior da pintura, da realidade circundante. ${ }^{302}$

No trabalho de Richter, portanto, a pintura isola a figura para manter uma separação segura e sugerir uma relação de contemplação tradicional pelo espectador. A coerência da obra aqui é dada por critérios tradicionais da pintura. Esse trabalho,

\footnotetext{
301 JUDD, Donald: “Objetos específicos”. Em FERREIRA, Glória; COTRIM, Cecília. Escritos de artistas. Rio de Janeiro: Jorge Zahar, 2006. p. 102.

${ }^{302}$ RICHTER, Gerhard. “Comments on Works (1991)”. Em ELGER, Dietmar; OBRIST, Hans Ulrich. Gerhard Richter - Text: Writings, Interviews and Letters. Londres: Thames \& Hudson, 2009. p. 260.
} 
especificamente, era para Richter "uma tentativa de me distanciar da imagem para me aproximar da pintura ${ }^{303}$ ".

Esse pêndulo de aproximação e distanciamento da imagem e de certo sentido de pintura parece estar presente em toda a obra de Richter. Contudo, seja mais imagem ou mais pintura, o trabalho sempre guarda a unidade compositiva da pintura. Uma imagem no interior da tela. O crítico Hal Foster definiu bem a diferença e as dívidas de Richter com Warhol. Segundo Foster: "Como Warhol, Richter se move em direção da dessublimação da pintura. (...). Ao mesmo tempo, diferente de Warhol, Richter também se esforça para manter sua frágil autonomia".304

Richter não transfere imagens gráficas prontas para a tela. Ele as refaz. Segue princípios claros para reproduzi-las: escolhe uma fotografia, em geral tomado pelo tema, projeta-a na tela por um episcópio e a pinta da maneira mais esquemática possível. Em geral, trabalha sobre a superfície depois que as figuras estão prontas, muito semelhantes à imagem. $\mathrm{O}$ artista pincela em uma mesma direção a tinta que não secou completamente. O trabalho do pincel cria indefinições que nos fazem pensar que aquela pintura replica uma fotografia levemente fora de foco. Mesmo que raramente Richter utilize imagens desfocadas.

As figuras, pinceladas depois de prontas, ganham uma consistência atmosférica. O esfumaçado nos traz a impressão de uma imagem desfocada, reforçando a ideia de que aquela pintura não é feita como um olhar para o mundo, mas é mediada por uma fotografia. Mas a imagem permanece íntegra, organizada por relações internas que em nada se relacionam com o espaço ao redor. A composição é clássica.

\footnotetext{
${ }^{303}$ Idem.

${ }^{304}$ FOSTER, Hal. "Gerhard Richter, or the photogenic image". Em The First Pop Age. Princeton: Princeton University Press, 2012. p.174.
} 
Assim, todos podem notar que aquela pintura é uma cópia de outra imagem previamente existente e que embora se pareça em demasia com a imagem original ganha maior opacidade quando é feita pintura. Quanto mais semelhante à foto, menos semelhante ao mundo visível. O artista trabalha como se adicionasse mais de uma camada entre o que se pretende ver e quem olha. ${ }^{305}$ Essa camada não torna nada mais nítido e nem dá um sentido formal novo para a imagem, ela tem algo de um anteparo translúcido.

Por isso, não se trata só de representar algum assunto escolhido e registrá-lo. Antes de se chegar ao assunto, precisamos lidar com camadas de significado prévio. Camadas de formas de representação. O interessante é que Richter diz que depois de se remover tanta ruína há alguma beleza, há alguma recompensa estética. ${ }^{306}$

Portanto, Richter acredita que a pintura, por meio de algum grau de manipulação, nos faz perceber algo que não perceberíamos de outro modo. Mesmo que seja apenas o aspecto vago, vazio, melancólico de boa parte de seus trabalhos. Depois de copiadas, as imagens impressas ganham outro sentido. O que está na fotografia, muitas vezes de maneira pouco composta, descompromissada, sem intenção artística - sobretudo a partir de 1965 - aparece em tinta a óleo como uma composição.

Passamos a perceber esses filtros de significado que se colocariam entre nós e o visível. Há um sentido atribuído para além da identificação do lugar, do personagem, do episódio que a imagem inicial registrava. Aliás, em muitas telas, vemos aquela imagem se livrar dos vestígios narrativos. Embora as pinturas sejam bastante semelhantes às

\footnotetext{
${ }^{305}$ Armin Zweite afirma que a fotografia atua como um filtro. ZWEITE, Armin. "Gerhard Richter's album of photographs, collages and sketches". Em BLAZWICK, Iwana; GRAHAM, Janna. Atlas, the reader. Londres: Whitechapel Gallery, 2004.

${ }^{306}$ RICHTER, Gerhard; "Notes, 1986". Em ELGER, Dietmar; OBRIST, Hans Ulrich. Gerhard Richter. Text: Writings, Interviews and Letters. Londres: Thames \& Hudson, 2009. p. 160.
} 
fotografias, alguma coisa se perde de vista ali. Conseguimos perceber o que é visto não por causa do tratamento pictórico, mas apesar dele.

Por isso, é preciso muito cuidado para comparar as declarações de Richter com seus trabalhos. Pensando na semelhança das pinturas com a fotografia, ele já fez o discurso de suas pinturas como antiartísticas, como se essa fotografia vernacular fosse uma forma mais honesta de produção de imagem que nas belas-artes ${ }^{307}$; e sabe que declarar o fim da pintura seria arrogante e presunçoso; ${ }^{308}$ já afirmou que seu diálogo permanente era com a história da arte ${ }^{309}$, e que encontrava atemporalidade nas obras de Johan Sebastian Bach e Giotto. ${ }^{310}$ Também já disse que decidiu pintar fotografias por motivos literários, única e exclusivamente pelo assunto. ${ }^{311}$

Há constantes, no entanto. Richter afirma que sua opção por pintar fotografias é justificada pela a eliminação do estilo em seu trabalho, pela redução da autoria, pela impessoalidade e pela distância do que se retrata. $O$ artista fala em "anulação das escolhas". ${ }^{312}$ Richter considera a fotografia a mais perfeita imagem. ${ }^{313}$ Ela evitaria a imposição da persona à realidade. Ela evitaria a ideia moderna de estilo. Por meio dela, conheceríamos o mundo de maneira supostamente mais neutra. A pintura da fotografia surgiria a nós como mais um anteparo, mais uma forma de ordenamento da imagem entre

\footnotetext{
307 "Eu considero muitas fotografias amadoras melhores que o melhor Cézanne. Não se trata de pintar boas imagens, porque a pintura é uma ação moral". Em RICHTER, Gerhard. "Text for exhibition catalogue, Hannover, 1966". Em ELGER, Dietmar; OBRIST, Hans Ulrich. Gerhard Richter. Text: Writings, Interviews and Letters. Londres: Thames \& Hudson, 2009. p. 43; ou "Fotografia para mim deveria ser mais relevante que a história da arte. (...) E eu não a tomei como um substituto da realidade, mas como uma muleta que me ajuda a me aproximar da realidade". Em RICHTER, Gerhard. "Interview with Peter Sager, 1972". Idem, p. 64.

${ }^{308}$ RICHTER, Gerhard. "Moma Interview with Robert Storr, 2002". Idem, p. 398.

${ }^{309}$ RICHTER, Gerhard. "Interview with Sabine Schutz, 1990". Idem, p. 253.

${ }^{310}$ RICHTER, Gerhard. "Interview with Jeanne Anne Nugent, 2006". Idem, p. 513.

${ }^{311}$ Cf. ELGER, Dietmar. Gerhard Richter: A Life in Painting. Chicago: University of Chicago Press, 2010. p. 49.

${ }^{312}$ Idem, p. 15.

${ }^{313}$ STORR, Robert. Gerhard Richter: Forty years of painting. Nova York: The Museum of Modern Art, 2002. p. 35.
} 
nós e o mundo. Ao mesmo tempo ela nos apresentaria algo e nos distanciaria daquele objeto.

Como formula Dietmar Elger, o historiador mais próximo e informado da carreira do artista, Richter nos faz acessar aquelas imagens com um novo critério. ${ }^{314} \mathrm{~A}$ informação fotográfica é reorganizada para a contemplação e se ressaltam suas propriedades formais. A imagem informativa aqui perderia essa função. Passaria a ser vista pelo que nunca a interessou, o modo de organização das formas. Aliás, propriedades formais que Richter não escolheu. Sua escolha é só o modo de apresentar aquelas imagens.

Como foi dito anteriormente, ao contrário da pintura de Warhol, o trabalho de Richter não se concentraria no reconhecimento imediato das personagens e das situações retratadas, mas em uma memória compositiva e iconográfica latente daquelas fotografias, no esquecimento de qualquer memória iconográfica consciente.

Mais tarde, Richter confessa que procura imagens fotográficas que se portem como pinturas, mas que quando transpostas na tela, pareçam as mais ingênuas fotografias. ${ }^{315}$ Ele inicia uma sobreposição de formas de representações da realidade que se encontram e se desencontram. Então, à medida que a pintura procurasse descrever a foto, perderia o objeto fotografado de vista.

O seu trabalho, mesmo nas pinturas abstratas, nos objetos, nos espelhos, nos vidros, é sempre a respeito de ver através de alguma superfície transparente ou translúcida. Ver através dessas camadas finas que se superpõem: pintura, fotografia, mundo visível, estruturas, linguagem etc. Por isso, há uma questão na dificuldade de

${ }^{314}$ ELGER, Dietmar. Gerhard Richter: A Life in Painting. Chicago: University of Chicago Press, 2010. p. 89.

${ }^{315}$ BUCHLOH, Benjamin H. D. "An interview with Gerhard Richter" (2004). Em BUCHLOH, Benjamin

H. D. (Org.) Gerhard Richter (October Files). Cambridge: MIT Press, 2009. p. 177. 
encontrar algo atrás daquela massa cinzenta, por exemplo na série de pinturas em que o artista utiliza fotografias sobre a trágica morte dos terroristas da R.A.F (70-91).

Gertrud Koch, no ensaio The Richter Scale of Blur, ${ }^{316}$ fala das maneiras distintas de perceber um objeto na pintura do artista. Ela parte de uma frase de Gerhard Richter para explicar essas condições de percepção. Segundo o pintor: "Você não vê menos quando olha para o mundo através de uma lente de aumento fora de foco". 317 Para o artista, você só percebe o mesmo objeto de outra maneira. Quando Richter pinta imagens microscópicas de uma trama de partículas de silicato, em forma de favo de mel, em Silikate (2003) (117 e 118), o que vemos não é uma descrição mais acurada da natureza, mas uma derivação, que nos faz vê-la como um padrão decorativo de uma pintura abstrata. O objeto e a representação do objeto desaparecem nessa descrição. Ver demais esgarça-o.

Nas fotopinturas de Richter, as coisas são vistas através de lentes grossas e com alguma refração. Os trabalhos que ele fez em vidro e espelho comentam tal mediação de maneira quase didática (114-116). Em tal conjunto de obras, a transparência neutra se torna um obstáculo para a visão, um anteparo na nossa relação com o mundo. Enxergar o trabalho de Richter é também ver esses obstáculos.

As promessas de objetividade em relação ao representado - a possibilidade de se entrar em contato, por meio de convenções de linguagem, com uma realidade distante de nós, até mesmo a promessa de se perceber o mundo de maneira diferente e, quem sabe, expandir a nossa consciência - ecoam antevisões utópicas e ideológicas que,

\footnotetext{
${ }^{316}$ KOCH, Gertrud. "The Richter-Scale of Blur". Em BUCHLOH, Benjamin H. D. (Org.) Gerhard Richter (October Files). Cambridge: MIT Press, 2009.

${ }^{317}$ Idem, p. 35.
} 
no mais das vezes, para Richter, nos abandonam no vazio. De acordo com o artista, não encontramos nada por trás dessa parafernália de analogias ideológicas.

Talvez o melhor exemplo dessa ideia de neutralidade ideológica sejam as pinturas de sombra que o artista fez em 1968 (107-109). Chamadas Schattenbild (Silhuetas), são trabalhos entre o abstrato e o figurativo. Embora o pintor trate fotograficamente o segundo plano do quadro, ele não partiu de nenhuma referência de imagem para compor as telas.

Nelas, uma sombra se projeta em um fundo neutro e metafísico, pintado como uma fotografia desfocada, com gradações de cinza, contorno levemente manchado e mudanças tonais suaves. Diante desse espaço, em boa parte dos trabalhos, o artista pinta formas ortogonais rosadas. Essas traves projetam as sombras que vemos ao fundo. Olhamos para as formas, como se elas fossem batentes de janela, intermediários entre o espaço da tela e o espaço comum. O lugar metafísico da pintura é contaminado por essa passagem. Diferente das sombras de Warhol, as sombras de Gerhard Richter não são fantasmagorias de um corpo que não está lá, são a lembrança de que sempre ao olhar para alguma representação, estamos camadas atrás do objeto que pensamos enxergar.

Em sua explicação do fotográfico em Richter, Jean François Chevrier ${ }^{318}$ compara Richter e Warhol. Afirma que ambos recorrem a fotografias comuns, dissociadas de qualquer sentido "artístico". No entanto, os dois artistas atribuem sentidos quase opostos à “imagem comum”. Segundo Chevrier, as imagens de álbum de família para Richter, por exemplo, "não podem ser reduzidas à sua aparente banalidade. Porque a pintura é capaz de preencher o valor de uso dessa imagem, como uma generalidade que

\footnotetext{
${ }^{318}$ CHEVRIER, Jean-François. "Between the fine arts and the media - The german example: Gerhard Richter” (1992). Em BLAZWICK, Iwana; GRAHAM, Janna. Atlas, the reader. Londres: Whitechapel Gallery, 2004.
} 
não se limita a um envolvimento emocional específico". ${ }^{319}$ Em Warhol, a imagem sempre teria esse valor de troca. Seria o equivalente de algo que todos reconheceríamos, seria uma imagem espetacular de quaisquer acontecimentos. As imagens de Richter não se tornam o substituto da presença de um personagem, mesmo porque se trata de mostrar figuras não necessariamente conhecidas, e quando conhecidas, despistadas.

Richter não estaria tão interessado no "valor icônico, nem no choque traumático do que foi fotografado, mas no poder latente da própria imagem". ${ }^{320}$ Quando convertidos em pintura, os esquemas compositivos da imagem fotográfica se identificariam com os esquemas iconográficos da tradição consolidados há tempos. A pintura estaria permeada por esse vocabulário. Demoraríamos para encontrar o representado por trás de tantas lentes. O olhar através dessas camadas translucidas é uma parte importante do trabalho de Gerhard Richter. A arte aconteceria por trás de sua segunda, terceira e até mesmo quarta camada de representação. ${ }^{321}$. O artista tenta ver o que permanece depois que a representação distanciou tanto de nós o que a arte queria mostrar. Por isso, parece apressado atribuir ao trabalho de Richter um sentido conceitual, que se esforçaria para desconstruir os esquemas de representação, insistindo todos os dias que não há mais nada para ser visto nas pinturas. Embora tenham esse caráter evanescente, a pintura tenta reter alguma coisa que reste, algum vestígio de que alguma coisa foi representada ali.

\section{Betty}

\footnotetext{
${ }^{319}$ Idem, p. 77.

${ }^{320}$ Idem, p. 80.

321 "Fotografia é agora parte de uma cadeia semiótica infinita de signos culturais: Os pintores que simplesmente pintavam "a partir da natureza" e então ficaram obsoletos com a fotografia agora pintam "a partir das fotografias" como uma segunda natureza ou mais". KOCH, Gertrud. "The Richter-Scale of Blur". Em BUCHLOH, Benjamin H. D (Org.) Gerhard Richter (October Files). Cambridge: MIT Press, 2009. p. 38.
} 
Em 1988, o artista já não morava nem em Dresden, onde se formou, nem em Dusseldorf, onde desenvolveu sua obra. Havia se mudado com sua companheira de então, a artista Isa Genzken, para Colônia, onde vivia perto do seu ateliê. A filha do seu primeiro casamento, com Marianne Eufinger, era uma mulher adulta e o período de construção de uma nova vida no ocidente ficara para trás. Richter já era um artista de prestígio, com um amplo debate intelectual sobre sua obra.

Já fazia um tempo que Richter pintava telas figurativas e abstratas. Mudava de procedimento de acordo com o que estava pintando. A forma se adequava a paisagens urbanas, sombras, retratos, natureza-morta, a toda sorte de motivos. O estilo não devia ser uma marca inconfundível, pessoal, era apenas uma forma de apresentar o motivo. Aliás, uma forma, no mais das vezes, simulada. Nas pinturas abstratas, fazia esquemas de cor geométricos e pinturas gestuais em que se esforçava para retirar o caráter expressivo do gesto e romper qualquer tentativa de organizar o plano. Pintava sobrepondo camadas de resíduos de uma pintura sobre outra.

Tal mudança de estilos de pintura, de assuntos, de produção, fez com que parte significativa da interpretação visse o trabalho como um comentário cínico da arte. Como se o artista "desmontasse estilo por estilo, ao fazer coisas diferentes ao mesmo tempo". ${ }^{322}$ Outros intérpretes preferem pensar os temas e as imagens com algum sentido icônico, alguma maneira de atribuir sentido iconográfico às imagens repintadas e relacioná-las ao conteúdo original das imagens. Em 2002, durante uma excelente entrevista com Robert Storr, Richter brinca com a controvérsia. Com ironia, mas certo de

\footnotetext{
${ }^{322}$ Robert Storr faz um comentário muito sintético de parte dessas interpretações na entrevista que faz com Richter para o catálogo da retrospectiva do Moma. RICHTER, Gerhard. "Moma Interview with Robert Storr, 2002". Idem, 2009. p. 397.
} 
que faz pintura sem nem um pingo dela, tenta tornar possível colocar lado a lado quem pensa que o seu trabalho é pintura e quem pensa que é antipintura.

\section{Robert Storr pergunta:}

Muitos americanos descobriram o seu trabalho com suas abstrações gestuais dos anos 1970 e 1980 sendo expostas ao lado da sua obra inspirada na pop, dos anos 1960, sem saber a diferença entre uma coisa e outra na obra de um mesmo artista.

O pressuposto era que você estava desmontando a pintura, estilo por estilo, fazendo coisas diferentes ao mesmo tempo. Então, eu me pergunto como você entendeu a recepção (...): quão confortável ou desconfortável você se sentiu com essa visão de você como uma espécie de pintor destrutivo?

Gerhard Richter, em tom de galhofa, responde:

Não percebi esse ponto de vista. Talvez eu estivesse feliz em receber atenção. Algumas pessoas até afirmam que era uma esperteza de minha parte. Havia uma demanda por pinturas que eu satisfiz, e ao mesmo tempo atendia essa noção conceitual contra a pintura - e então eu servi os dois lados. Isso foi bastante inteligente, uma legitimação para agradá-los. Porque com este fundo intelectual e conceitual, você sempre tem uma desculpa. Eles são coloridos e pictóricos, mas também são muito intelectuais. Tenha cuidado! $!^{323}$

\footnotetext{
${ }^{323}$ Idem, p. 397.
} 
Embora fizesse piada, ele apontava que as duas coisas estavam de alguma forma no seu trabalho. Não era de todo falso que o artista se preocupasse com as formas de representação. Elas eram e ainda são um assunto importante de suas pinturas. No entanto, sua obra é pensada trabalho a trabalho. Eles não são a ilustração de um projeto. Possuem especificidades e seguem um caminho intuitivo.

O que o artista fez no ano de 1988 guarda uma relação com seu contexto. O modo de tratar as fotografias escolhidas, no caso das pinturas figurativas, comenta dilemas históricos e pessoais do artista na época. Em uma entrevista feita dois anos antes, em 1986, com Benjamin Buchloh, quando o crítico afirma que a pintura de Richter nega o conteúdo dos temas, e que eles seriam aleatórios, Richter nega veementemente: "Os motivos nunca foram escolhidos aleatoriamente. Basta você pensar no trabalho que eu tive para encontrar fotografias que eu poderia usar". ${ }^{324}$

Em 1988, Richter pintou Betty (56), uma cena de sua filha, a olhar para um fundo cinza esverdeado, escuro e indefinido. A pintura foi feita a partir de uma fotografia capturada pelo artista ao menos dez anos antes de ser pintada. ${ }^{325}$ Richter incorporou a imagem ao seu acervo de referências, documentos ${ }^{326}$ e projetos conhecido como Atlas, depois de fazer a tela.

Como a datação das imagens da página 445 do Atlas, ${ }^{327}$ onde a fonte da pintura está indexada, não é precisa, fica difícil definir quantos anos Babette Richter tinha

\footnotetext{
${ }^{324}$ RICHTER, Gerhard. "Interview with Benjamin H.D. Buchloh, 1986". Em ELGER, Dietmar; OBRIST, Hans Ulrich. Gerhard Richter. Text: Writings, Interviews and Letters. Londres: Thames \& Hudson, 2009. p. 80. ${ }^{325}$ ELGER, Dietmar. Gerhard Richter: A Life in Painting. Chicago: University of Chicago Press, 2010. p. 192.

${ }^{326}$ RICHTER, Gerhard. "Interview with Gregorio Magnani, '1989”'. Em ELGER, Dietmar; OBRIST, Hans Ulrich. Gerhard Richter. Text: Writings, Interviews and Letters. Londres: Thames \& Hudson, 2009. p. 224.

${ }^{327}$ De acordo com o site do artista, a imagem foi feita em 1978, mas a datação do catálogo RICHTER, Gerhard. Atlas. Colonia: Verlag der Buchhandlung Walter König/Nova York: DAP, 2006 (segunda edição, 2011) indica que as fotografias foram realizadas em 1978, 1984 e 1988.
} 
quando a fotografia foi feita. Certamente, ela era ainda adolescente, significativamente mais nova que a jovem de 22 anos da época em que o quadro foi pintado. É muito possível que o artista tenha feito a foto por volta de 1977, época em que ele pintou outros dois retratos da filha.

Há a hipótese de que certa nostalgia da infância da filha tenha motivado a realização dessa pintura. O argumento de Kaja Silverman, por exemplo, depende dessa suposição. ${ }^{328}$ Ela menciona a pintura como uma lembrança de uma terna relação de paternidade que, provavelmente, se transformava na época em que a pintura foi feita. A imagem, mesmo melancólica, guardaria um momento terno da filha.

O fim da década de 1980 marca o fim de muitas aspirações do século XX. Richter sente o baque. Mesmo ele, que sempre recusou as promessas grandiloquentes de todas as utopias, crenças e convergências pacificadoras e pretensamente universalistas do período, fosse a religião, o fascismo, o comunismo, a sociedade de consumo. $\mathrm{O}$ artista via nessas convicções mais os horrores do nazismo e da Alemanha Oriental. Mesmo assim, pinta em 1988 telas melancólicas, que tratam tanto da morte da utopia, quanto da morte pela utopia.

A Alemanha já não era a mesma. O país já renegociava sua reunificação, e a União Soviética estava próxima do fim. A Alemanha Ocidental, que foi o maior enclave da Guerra Fria, deixaria de existir, se unificaria com sua metade comunista. Os horizontes de transformação radical da realidade, e mesmo o sentido de refundação da sociedade, da cultura, da arte, da ciência, não tinham mais o mesmo significado. O trabalho de Richter, que sempre foi desencantado, resolveu comentar esses tempos.

${ }^{328}$ Cf. SILVERMAN, Kaja. Flesh of My Flesh. Stanford: Stanford University Press, 2009. 
Ao mesmo tempo em que o artista pinta sua filha, faz uma série importante, talvez sua série mais importante, 18 de outubro de 1977. Nela figuravam cenas relativas à morte dos militantes do Grupo Baader-Meinhoff - nome que a imprensa deu à chamada Primeira Geração da RAF. (sigla para Rote Armee Fraktion, Fração do Exército Vermelho em alemão) ${ }^{329}$. A série 18 de outubro de 1977 era feita a partir da prisão e morte dos terroristas da RAF. As imagens que o artista pintava pareciam falar da degradação da utopia e de qualquer esperança civilizatória do Estado alemão. ${ }^{330}$ A pintura era feita a partir de um episódio nebuloso da história recente da Alemanha, onde ninguém parecia ter razão. Naquela época, a RAF ainda estava na ativa e os atentados e mortes que seguiram sua história eram muito recentes. A União Soviética esperava sua queda, e o ocidente não trazia grandes promessas. Nesse contexto, uma pintura da sua família, com um casaco aveludado, em um ambiente doméstico, foi frequentemente associada a uma espécie de conforto familiar possível diante da ausência de promessas.

Betty e a série sobre o chamado Outono alemão ${ }^{331}$ retomavam um tema vinculado de alguma maneira ao ano de 1977. A morte dos membros da RAF aconteceu naquele ano, quando Richter faz os primeiros retratos de sua primogênita. Ambos também lidam com a memória: fosse ela histórica ou familiar. Betty (1988), pintada nessa época,

\footnotetext{
${ }^{329}$ Segundo Tom Vague o nome do grupo é uma brincadeira com o nome de duas tropas que derrotaram a Alemanha nazista: A Royal Air Force (RAF) inglesa e o Exército Vermelho Soviético. Em VAGUE, Tom. Televisionários: a história da facção Exército Vermelho, mais conhecida (por engano) como Grupo Baader-Meinhoff. São Paulo: Conrad, 2001. p. 50.

${ }^{330}$ DANCHEV, Alex. "The Artist and the Terrorist, or The Paintable and the Unpaintable: Gerhard Richter and the Baader-Meinhoff Group". Source: Alternatives: Global, Local, Political, v. 35, n. 2, abril/jun. 2010. p. 93-112. Thousand Oaks: Sage, 2010.

BUCHLOH, Benjamin. A Note on Gerhard Richter's October 18, 1977. October, v. 48, primavera, 1989. p. 88-109.

${ }^{331}$ Período entre julho e outubro de 1977, quando a Alemanha vive um estado de emergência não declarado. O conflito entre as RAF, as células revolucionárias e o Estado alemão atingem o seu ápice. É a segunda geração da luta armada terrorista que toma lugar. Nessa época se dá o assassinato do empresário Jurgen Ponto, a tentativa de se lançar um foguete no prédio da Promotoria em Karlsruhe, o sequestro de Hans-Martin Schleyer, o sequestro do avião da Japan Airlines pelo Exército Vermelho Japonês, e o da Lufthansa pelas Células Guerrilheiras alemãs e por um grupo ligado à Frente Popular de Libertação da Palestina. O período se encerra com as mortes, sob condições discutíveis dos militantes da RAF. Bom resumo em STORR, Robert. Gerhard Richter: October 18, 1977. Nova York: The Museum of Modern Art, 2000. (. 4167.
} 
soa para autores como Christian Lotz, ${ }^{332}$ Benjamin Buchloh ${ }^{333}$ e Dietmar Elger ${ }^{334}$ como um contraponto às pinturas do 18 de outubro de 1977. Betty estaria refugiada do turbilhão de violência, ruído e falta de sentido da história. A imagem de Betty seria a da contemplação silenciosa e pacífica, de certa privacidade burguesa.

Assim, as imagens de 1988, melancólicas e resignadas, falam das desilusões e das alegrias possíveis, mesmo que ínfimas do nosso tempo. Acredito que isso, no entanto, vá além do tema e nos ajude a entender o sentido de imagem para Richter. As imagens de seus filhos, sua esposa e ex-esposas, como concorda boa parte da bibliografia, a imagem de uma memória acolhedora para o artista, a imagem da "felicidade doméstica burguesa possível", 335 embora não transforme o que vemos em uma quimera, faz com que aquela lembrança se mostre como algo distante, inatingível, em desencontro com a realidade.

Em ensaio recente, Christine Mehring interpreta o grupo de pinturas conhecido como "pinturas de família" como parte de um imaginário nostálgico de um artista que, exilado, não pode ver nem sua mãe nem seu pai falecerem. Mehring diz que Richter viu o seu país se transformar tantas vezes que jamais se reconheceria em casa. ${ }^{336}$ O argumento é bastante convincente e nos faz atentar para uma dimensão nostálgica do trabalho de Richter, talvez até conservadora, no sentido de passadista. No entanto, esse

\footnotetext{
${ }^{332}$ LOTZ, Christian. The Art of Gerhard Richter. Hermeneutics, Images, Meaning. Londres: Bloomsbury Press, 2015. p. 153.

333 BUCHLOH, Benjamin. "A Note on Gerhard Richter's October 18, 1977. October, v. 48, primavera, 1989. p. 88-109.

${ }^{334}$ ELGER, Dietmar. Gerhard Richter: A Life in Painting. Chicago: University of Chicago Press, 2010. p. 307.

335 Robert Storr identifica essa ideia de felicidade familiar burguesa de Richter como uma resposta às promessas utópicas, a esperanças de conciliação com a realidade de quaisquer ideologias. Cf. STORR, Robert: Gerhard Richter: Forty years of painting. Nova York: The Museum of Modern Art, 2002. ${ }^{336}$ MEHRING, Christine. "Richter's Willkür", Art Journal, v. 71, n. 4, inverno, 2012. p. 20-35. College Art Association, 2012.
} 
passado melancólico se apresenta como irrecuperável, uma lembrança que nunca se apresenta de maneira íntegra.

As imagens memorialísticas registradas em foto seriam parâmetro tanto para se aproximar do que passou, como para indicar que aquilo havia se tornado, digo por minha conta, uma ruína. Os dois retratos que o artista fez da sua filha em 1977, e a cena de 1988 dão sequência à série de pinturas feitas a partir de fotografias caseiras, iniciada em 1963.

A Betty de $1988^{337}$ era uma fotopintura atípica. Foi feita com um grau de detalhamento e de verossimilhança fotográfica muito maior do que a maioria das pinturas de Richter. Ela parecia mais descritiva e mais ilusionista que trabalhos anteriores. Vemos a personagem de perto, com o desfocado conhecido como blur, atenuado de maneira significativa no primeiro plano da pintura. O molde do corpo, o caimento e o pregueado dos tecidos são feitos de modo muito detalhista. A luz ressalta os volumes, concavidades, sobretudo no corpo da menina. Embora o fundo seja bastante indefinido, a pintura representa uma solidez incomum nos trabalhos de Richter.

Tal rigor fez com que Richter fosse aproximado, contra sua vontade, de artistas do realismo fotográfico ${ }^{338}$ norte-americano, como Robert Bechtle (101) e Richard Maclean (102), ${ }^{339} \mathrm{Em}$ um texto sobre as "fotografias feitas à mão", Thomas Crow tenta ver semelhanças e diferenças entre o artista de alto prestígio e pintores mais próximos do

\footnotetext{
${ }^{337} \mathrm{O}$ artista fez dois retratos da filha em 1977, uma aquarela em que ela é representada ao lado de Isa Genzken, então esposa de Richter, de 1987 e uma pintura sobreposta a uma fotografia em 1989. Betty aparece no Atlas em outros momentos.

338 "Os fotorrealistas parecem acreditar mesmo no que estão fazendo. Eles encontraram o seu caminho de vez. (...) Eu não consigo acreditar nisso com tanta convicção". RICHTER, Gerhard. "Interview with Irmeline Lebeer, 1973”. Em ELGER, Dietmar; OBRIST, Hans Ulrich. Gerhard Richter. Text: Writings, Interviews and Letters. Londres: Thames \& Hudson, 2009. p. 80.

${ }^{339}$ A comparação entre o prestigioso pintor e artistas quase naif é apontada de maneira esperta por Thomas Crow. CROW, Thomas. "Handmade photographs and homeless representation"; Em Modern Art in the Common Culture. New Haven: Yale University Press, 1996. p. 105-110.
} 
kitsch. ${ }^{340}$ Embora inicie a reflexão com um questionamento sobre o prestígio, o autor logo passa aos diferentes resultados estéticos e constata aspectos importantes da obra de Richter.

Crow fala que ao contrário dos hiper-realistas, Richter não tenta produzir uma imagem tão transparente e ilusionista. $\mathrm{O}$ uso do foco também é diferente, sobretudo se compararmos fundo e figura. No trabalho de Richter, a figura, em primeiro plano é menos embaçada do que o fundo cinza indeterminado. Portanto, a composição é menos homogênea. Além disso, Richter trabalha com uma forma mais simples, menos anedótica, que elimina qualquer elemento pitoresco.

A partir daí, dá para concluir que enquanto Richter vê as dificuldades de endereçamento da fotografia, o hiper-realismo promete um supra ilusionismo, uma submissão da pintura à imagem publicitária - diferente inclusive de Warhol, que equivale as duas formas de produção visual. Os hiper-realistas envernizam a imagem comercial por meio da pintura. Como bem sintetiza Crow: "Richter cria efeitos que chamam a atenção pela esplêndida intensidade de promessas que nunca serão cumpridas". 341

O trabalho é sobre isso. É sobre a contemplação de algo que mal se define. A representação da contemplação, da observação, do olhar é tradicional na história da arte. Por isso, Betty encontra eco em uma vasta produção histórica, apesar de feita a partir de uma fotografia amadora, sem pretensões estéticas. A pintura já foi comparada a trabalhos

\footnotetext{
${ }^{340}$ Quem bem aponta a distinção dos procedimentos dos fotorrealistas (ou híperrealistas) e Richter é Jean François Chevrier. Segundo Chevrier, "Onde os fotorrealistas monumentalizam uma imagem descritiva e evitam um tipo de "fotografia muito sincera" (preferindo a finalização limpa de uma imagem profissional mais comercial). Richter, pelo contrário, aproveita o excesso de descrição. Ele é muito mais atraído por instantâneos banais do que as fotografias artísticas compostas; as últimas são imagens profundamente empobrecidas, com seu jogo de luz e sombra, a sua harmonia e efeitos de composição. Por comparação, a foto de família, com todos apertados no meio da imagem, está repleta de vida.”. Em CHEVRIER, JeanFrançois. "Between the fine arts and the media (The german example: Gerhard Richter 1992)". Em BLAZWICK, Iwana; GRAHAM, Janna. Atlas, the reader. Londres: Whitechapel Gallery, 2004, p. 76. ${ }^{341}$ Idem, p. 110.
} 
como Christina's World, de Andrew Wyeth, ${ }^{342}$ (63) e Mulher na janela, de Caspar David Friedrich $^{343}$ (64). Esses três trabalhos lidam com o mesmo assunto. Representam uma figura feminina, de costas para nós, mirando algo mais amplo que ela, no fundo da tela.

Na americana de Andrew Wyeth, Christina, a personagem da cena, que já foi descrita como uma garota que sofria com as consequências da poliomielite, ${ }^{344}$ é apresentada sentada de lado, apoiada nas mãos, com as pernas largadas do lado oposto ao dos membros superiores. A torção no quadril, embora aponte a cabeça da mulher para a direita, faz lembrar a postura representada por Richter em Betty.

Com o cabelo despenteado pelo vento, Christina olha para a casa de longe, com um amplo campo entre ela e a construção. Embora Wyeth descreva a cena como uma menina a pegar frutas no chão. A tela parece mais aflitiva. O prado é de uma vegetação amarelada, em um lugar isolado, com sol a pino e vento. Não se vê nada além do gramado e das casas. A pintura pode ser tomada como uma alegoria do isolamento da vida rural. Wyeth era um artista de comentário cultural. Pintava o que acreditava serem as especificidades da vida americana. Esse tipo de imagem se relaciona com o drama desbravador associado ao país.

Embora não enxergue tão longe quanto a figura de Wyeth, a mulher debruçada na janela de Friedrich vê mais. Ela não está em meio a uma paisagem. Olha de dentro de casa para fora. O pintor contrapõe o recolhimento da casa a uma paisagem

\footnotetext{
342 Idem, p. 105.

${ }^{343}$ BORCHARDT-HUME, Achim. "“Dreh Dich Nicht Um': Don't turn around, Richter paintings of the late 1980s". Em GODFREY, Mark; SEROTA, Nicholas. Gerhard Richter|Panorama. Londres: Tate, 2011. p. 164. O próprio Richter faz essa comparação frequentemente. Em uma carta de 1973, destinada a Jean-Christophe Amman, muito reveladora, ele diz que “(...) é bem possível pintar como Caspar David Friedrich". RICHTER, Gerhard. "From a letter to Jean-Christoph Amman, February 1973". Em ELGER, Dietmar; OBRIST, Hans Ulrich. Gerhard Richter. Text: Writings, Interviews and Letters. Londres: Thames \& Hudson, 2009. p. 72.

${ }^{344}$ HUGHES, Robert. American Visions. Nova York: Alfred Knopf, 1997. p. 508.
} 
luminosa e arrebatadora. O abrir da janela é um encontro com uma maravilha. Esses contrapontos parecem permear toda a tela.

Betty também é uma cena de interior, mas nenhum traço de paisagem se revela. A menina olha para um fundo escuro e atmosférico. Nada se revela direito ali, o fundo é vaporoso. A figura é proporcionalmente maior aqui do que nos outros quadros. O ombro esquerdo da menina aponta em nossa direção, tenciona o tecido, fazendo com que o corpo se molde em uma constituição tátil. Casaco, vestido, pele e cabelo são apresentados com texturas distintas. Embora Richter atenue significativamente o sombreado da fotografia que ele copia, notamos concavidades, convexidades, regiões mais sombreadas e outras mais iluminadas. No fundo, os contornos se suavizam e perdem a definição.

A indefinição é ampliada por uma espécie de halo brilhante ao redor da cabeça da personagem. No canto esquerdo da figura, como no alto de sua cabeça, sobram pinceladas delgadas, veladuras brancas, borrados discretos. A contemplação de Betty parece ser sensivelmente distinta das pinturas anteriores. Ela nos ajuda a entender o que Richter procura ao pintar a imagem.

Enquanto nos quadros dos outros artistas, as observadoras se dão conta de fenômenos naturais complexos e intensamente físicos, Betty olha para um espaço artificial. Mesmo que a natureza tenha um sentido mais social em Wyeth e mais religioso e idealizado em Friedrich, ambos os trabalhos lidam com formas da contemplação, ou observação, de atribuição de sentido à natureza. Em Betty não há natureza, aliás, não há ninguém, não há nada. Richter copia uma fotografia cujo sentido estava dado, resta saber se esse sentido se mantém quando a imagem se torna pintura. 
A aproximação com a tradição não é acidental ou irrefletida na obra do artista. A pintura de Gerhard Richter assume um diálogo direto com a história da arte. Em trabalhos de 1967, como Olympia e Banhistas, essa menção já está bastante explícita. Nessas obras, um caráter iconoclasta ainda estava presente. Elas partem de fotos extraídas de revistas pornográficas ordinárias e esquemáticas. A partir dessa forma de produção de imagem, o artista insinuava os modos de organização de grandes pinturas da modernidade, como Olympia (1863), de Édouard Manet, e O Banho Turco (1862), de Jean-Dominic Ingres. Elas estão aproximadas pelos temas ou pela forma de apresentação dos corpos femininos.

Da mesma forma, Ema (Nua na escada) (1967) emula o Nu descendo da escada (1912), de Marcel Duchamp; e Nus espanhóis (1967), comenta a série Les demoiselles d'Avignon (1907), de Pablo Picasso. Em todos esses trabalhos, a sugestão é suave, atribuída ao tema por título ou, no caso de Ema e dos Nus espanhóis, pela pose das figuras. Tais temas aqui são mostrados de maneira desidratada, como se o erotismo, a velocidade ou a provocação tivessem ficado para trás. Como se não houvesse transformação moderna possível.

No amplo grupo de telas feitas a partir de fotografias de família (63 e 68), ${ }^{345}$ à qual Betty pertence, o artista também tenta estabelecer identidade entre a imagem "não composta" da foto doméstica e a memória de convenções, formas e temas da arte tradicional. O pintor indicaria a presença desses esquemas de representação nas imagens mais "neutras" e descompromissadas.

\footnotetext{
${ }^{345}$ Esse é um dos eixos mais importantes do trabalho de Richter. Ele atravessa os diversos temas que organizam as fotopinturas do seu catalogue raisonée e atravessa também as épocas. $\mathrm{O}$ artista pinta quadros a partir de imagens do seu acervo doméstico desde 1964. Disponível em: https://www.gerhardrichter.com/en/art/paintings/photo-paintings/.
} 
Essas associações não são necessariamente conscientes. Por exemplo, em 2000, quando perguntado se tinha a intenção de citar Menina lê uma carta (1657), de Johannes Vermeer, quando pintou Lesende (1994) (65), Richter disse que não. Não descartou, contudo, a hipótese da pintura de Vermeer estar inconscientemente em sua mente quando escolheu o tema. A menina de Vermeer teria posição constitutiva na sua educação como pintor e no que ele entendia como arte; isso provavelmente estava presente em suas reflexões. ${ }^{346}$

No fim dos anos 1960, tal endereçamento à história da arte se torna muito mais frequente na produção do pintor. ${ }^{347}$ Aliás, à medida que ele se ocupa mais de pinturas abstratas do que de pinturas figurativas, suas fotopinturas tendem a emular assuntos, formas de composição e gêneros da pintura tradicional. A presença é óbvia na série de "réplicas" que Richter faz a partir da fotografia de uma anunciação de Ticiano, na série Anunciação a partir de Ticiano, ${ }^{348}$ de 1973; nas chamadas "paisagens românticas"349 iniciadas em 1968 -, e, sobretudo, na série 48 Retratos (1971), exibida na Bienal de Veneza de $1972 . .^{350}$

\footnotetext{
${ }^{346}$ RICHTER, Gerhard. "Interview with Astrid Kasper, 2000". Em ELGER, Dietmar; OBRIST, Hans Ulrich. Gerhard Richter. Text: Writings, Interviews and Letters. Londres: Thames \& Hudson, 2009. p. 369.

${ }^{347}$ Provavelmente, o primeiro trabalho que o artista faz remissão direta à história da arte é Flämische Krone, de 1965 (121). Segundo o artista, ele pensava em Frans Hals quando fez a pintura. Provavelmente, esse é um dos primeiros trabalhos que o artista também faz a partir de uma fotografia feita por ele mesmo. Cf. RICHTER, Gerhard. "Comments on some works, 1991". Em ELGER, Dietmar; OBRIST, Hans Ulrich. Gerhard Richter. Text: Writings, Interviews and Letters. Londres: Thames \& Hudson, 2009. p. 261.

${ }^{348}$ Nesse jogo de referências, não custa lembrar que essa anunciação de Ticiano remete à Anunciação de Giovanni Bellini na Accademia de Veneza.

${ }^{349}$ Quando perguntado por Irmeline Lebeer se a associação de seu trabalho com o romantismo era incômoda, Richter responde: "De jeito nenhum. Para mim, há uma autêntica referência histórica ao romantismo. É o que me distingue dos híperrealistas. Eles pintam nosso mundo contemporâneo, eu faço pinturas históricas". RICHTER, Gerhard. "Interview with Irmeline Lebeer, 1973". Em ELGER, Dietmar; OBRIST, Hans Ulrich. Gerhard Richter; Text: Writings, Interviews and Letters. Londres: Thames \& Hudson, 2009. p. 82.

${ }^{350} \mathrm{~A}$ ida à Veneza inspira o trabalho com base na pintura de Ticiano. Antes disso, o artista já pintara dois quadros a partir de imagens de pinturas, mas elas eram reproduzidas em preto e branco, a partir de fotografias de outras pessoas.
} 
Nesse conjunto de pinturas, Richter refez retratos de homens brancos célebres: cientistas, escritores, filósofos, pensadores. A princípio também haveria políticos, ideólogos, mas Richter preferiu retirá-los. Pretendia dar uma conotação politicamente neutra e incontroversa. A ideia do saber aqui é a da ideia nada neutra de “contribuição universal para a humanidade".

Essa universalidade, apontada por críticos como Benjamin Buchloh e Hal Foster, é bastante particular, do ponto de vista racial e de gênero. Na série não há não brancos nem mulheres. Embora apareçam homens de outras raças como Gandhi, Mao Tse-Tung e Ho Chi Mihn, nos arquivos incluídos no Atlas, eles não são escolhidos para as pinturas.

O trabalho foi feito a partir de fotografias retiradas das enciclopédias, realizadas por profissionais anônimos, de acordo com princípios consolidados. Richter escolheu imagens tão protocolares quanto os retratos em três por quatro de estúdio fotográfico. São imagens com mais ou menos a mesma forma, a mesma proporção. Pensadas como série, o sentido das pinturas, no mesmo formato, é dado pela comparação de uma com a outra. A coleção reiterava os esquemas da arte do retrato. Tais convenções poderiam ser utilizadas no retrato de qualquer um. O assunto da série também é a estrutura, uma forma de apresentar por meio da imagem que atenua as particularidades e distinções. A notável semelhança entre as pinturas nos põe a pensar nos critérios de seleção dessa "universalidade".

A imagem final é da construção de um cânone. Um cânone homogêneo, capturado a partir de esquemas de representação muito limitados. Embora a crítica tenha percebido um interessante comentário cultural nessas escolhas, acredito que o que importava para Richter não era isso, mas alguma homogeneidade nos retratos. 
Interessava-lhe a estrutura engessada do gênero. A série nos apresenta o cânone como uma coleção maçante, pretensamente neutra e, por isso, absolutamente ideológica.

Aliás, foi em 48 Retratos que Richter definiu os princípios técnicos de sua fotopintura, as maneiras de produzir seu suave desfocado. O trabalho é feito com cautela, pincelando a imagem terminada sempre na mesma direção, antes de a tinta secar totalmente. $^{351}$

É uma das séries mais estruturais do pintor. Não por acaso, essa série é uma das que reforça as interpretações mais conceituais do trabalho de Richter. ${ }^{352}$ Ela tenta esvaziar o conteúdo das formas, transformando a razão do seu cânone em nonsense. Em 1988, respondendo a uma pergunta de Michael Archer, Richter marca uma linha para se diferenciar de Hermannsschacht (1988), de Anselm Kiefer. Diz que enquanto o trabalho de Kiefer indica preferência, um critério de escolha das personagens, o seu trabalho indicaria um vazio desses critérios ideológicos e arbitrários ${ }^{353}$.

Em Betty, os critérios ideológicos de representação aparecem de uma outra forma. A relação com a imagem, mais que qualquer outra coisa, é diferente. Embora a pintura copie uma fotografia, que ressoa outros trabalhos de arte, ela pede maior contemplação. Aliás, a pintura é sobre isso: o que encontramos ou não no esforço de observar detidamente uma imagem diante de nós. O que está posto nela quando convertida em pintura? Há ainda algo para a arte nos dizer?

\footnotetext{
${ }^{351}$ ELGER, Dietmar. Gerhard Richter: A Life in Painting. Chicago: University of Chicago Press, 2010. p. 195-196. 352 BUCHLOH, Benjamin. "Atlas de Gerhard Richter: o arquivo anômico". Arte \& Ensaios, Rio de Janeiro, n.19, 2009, p.194-209.

${ }^{353}$ RICHTER, Gerhard. "Conversation with William Furlong, Jill Lloyd, Michael Archer and Peter Tonwsend, 1988”. Em ELGER, Dietmar; OBRIST, Hans Ulrich. Gerhard Richter. Text: Writings, Interviews and Letters. Londres, Thames \& Hudson, 2009. p. 211.
} 
Embora tematizasse a observação, a contemplação, isso não era um problema para um artista como Caspar David Friedrich. Era óbvio que havia algo para ver na natureza e na imagem, essa natureza era descrita e ordenada. A contemplação da figura mimetizava o encantamento do artista. O modo de Caspar David pintar a natureza era idealista. Ele tenta descrever de maneira clara essa força divina e brutal.

Richter frequentemente volta a Caspar David Friedrich ${ }^{354}$. Betty retoma a rückenfigur, um tema recorrente de Friedrich. O historiador Joseph Leo Koerner a descreve como uma figura vista de costas, solitária ou não, em um encontro arrebatador com a paisagem ${ }^{355}$. Em Mulher na janela (64), frequentemente comparado com Betty, não há paisagem significativa. Friedrich representa uma mulher de costas, debruçada na janela, de cabelo cuidadosamente preso. Michael Fried acredita que a mulher seja a esposa de Caspar David, Caroline Friedrich ${ }^{356}$. O que a personagem recebe é um banho ofuscante de luz vindo de um bosque de árvores altas, diante de um rio com barcos boiando mansamente. Aquele brilho é uma epifania.

Caroline Friedrich está vestida em um severo vestido verde escuro que ecoa em grande medida o sombreado do interior da casa. Centralizada, ela inclina o corpo levemente para a esquerda. Do parapeito, olha arrebatada a paisagem luminosa em franco contraste com o interior simétrico, sóbrio e fechado. O mundo se abre para os seus olhos, com uma intensidade que contrasta com o interior. A paisagem que ela enxerga é mais ampla e mais brilhante. Tem algo de um momento fiat lux.

\footnotetext{
${ }^{354}$ RICHTER, Gerhard. "From a letter to Jean-Christoph Amman, February 1973”. Em ELGER, Dietmar; OBRIST, Hans Ulrich. Gerhard Richter. Text: Writings, Interviews and Letters. Londres: Thames \& Hudson, 2009. p. 72. Em outra circunstância, conta que foi à Groenlândia em busca das paisagens que inspiraram a tela conhecida como Naufrágio da esperança (1823-1824) (110). O mais interessante, pois se relaciona com a obra de Richter, é que ele não encontrou imagens como aquelas para fotografar. ${ }^{355}$ KOERNER, Joseph Leo. Caspar David Friedrich and the Subject of Landscape. 2. ed. Londres: Reaktion, 2009. (Primeira edição em 1990.) p. 163.

${ }^{356}$ FRIED, Michael. “Orientation in painting”. Em Another light: Jacques-Louis David to Thomas Demand. New Haven: Yale University Press, 2014. p. 122.
} 
Pela nossa posição em relação à figura, quem olha e o que é visto são postos em contraste ${ }^{357}$. Na interpretação que Robert Rosenblum faz dos personagens de Friedrich, “o indivíduo é posto diante de, ou confrontado com a imensidão esmagadora e incompreensível do universo, como se os mistérios da religião abandonassem o ritual da igreja e da sinagoga e tivessem sido alocados no mundo natural"358. A beleza romântica seria uma divinização mística do mundo visível. Um encontro com a santidade expressa na contemplação da natureza ${ }^{359}$.

A pintura de Richter parece ir na direção contrária. As costas da observadora têm aparência expansiva e colorida; o que é observado não; é uma zona cinzenta e mal definida. Isso é complicado pelo fato da pintura ser uma cópia de uma fotografia. Tudo é percebido indiretamente. Não se trata de um estilo peculiar de representação, que tenta significar a cena. Richter pinta o que vemos como se simulasse os efeitos de uma câmera. A pintura aparenta ser mais 'fotográfica' do que a imagem que lhe serviu de motivo.

A textura da tela é aveludada e inclui um desfocado suave, que se intensifica na medida em que a imagem vai para o fundo. Tal efeito não está na fotografia (58) projetada na tela, mas em sua representação pictórica (56). Por outro lado, ao transferir uma fotografia aparentemente caseira, inocente, desinteressada e sem estilo para a tela, o artista encontra, como foi dito antes, convenções da pintura nela. Como ele prefere dizer, encontra uma pintura ${ }^{360}$.

\footnotetext{
357 O tema vem do excelente estudo de Joseph Leo Koerner. Em KOERNER, Joseph Leo. Caspar David Friedrich and the Subject of Landscape. 2. ed. Londres: Reaktion, 2009. (Primeira edição em 1990.) p. 9. ${ }^{358}$ ROSENBLUM, Robert. Modern Painting and The Northern Romantic Tradition: Friedrich To Rothko. Nova York: Harper Collins (Icon Editions), 1977. p. 14.

${ }^{359}$ Michael Fried entende que os observadores de Friedrich estão em um esforço de cognição, de atribuição de sentido àquela paisagem. Cf. FRIED, Michael. "Orientation in painting". Em Another light: Jacques-Louis David to Thomas Demand. New Haven: Yale University Press, 2014.

$360 \mathrm{~A}$ escolha das fotos a serem pintadas e incorporadas ao Atlas é muito cuidadosa. O artista conta que, comparativamente, poucas fotos são incorporadas ao Atlas e menos ainda é utilizado como motivo da pintura. Parte significativa de seu trabalho, da mesma maneira que alguns fotógrafos, como Bernd e Hilla Becher, é ordenar esse arquivo.
} 
Esse jogo de espelhos amplia as contradições do trabalho e as controvérsias de sua interpretação. Não sabemos se o que encontramos ali é a representação de uma cena, a representação de uma imagem, ou a representação de esquemas de pintura. De fato, as três coisas estão sobrepostas no trabalho.

O tema, a imagem fotográfica por meio do qual encontramos o tema, a pintura dessa imagem fotográfica. Entre as convenções da pintura, a afirmação do efeito fotográfico e o olhar do observador, podemos pensar que não há nada para se ver ali. No entanto, talvez seja nos desencontros entre essas formas de se mostrar ao espectador que o trabalho acontece.

Uma escola de leitura desses trabalhos insiste no seu caráter conceitual. Como se obra de Richter fosse um comentário sobre a "natureza da arte e seus limites". Em 1975, o curador Manfred Schneckenburger, em um texto chamado "Gerhard Richter, uma maneira de continuar pintando 361 ", disse que Richter "não pinta com gestos amplos quando ele pinta pinturas gestuais, nem abstratamente quando ele pinta pinturas abstratas, nem expressivamente quando pinta pinturas expressionistas, assim como ele não compõe quando ele pinta uma foto de família hierarquicamente posicionada. Ele usa estilos artísticos como padrões, assim como ele usa fotos como modelos, para explorar o processo de pintura ${ }^{362 " .}$

Nessa interpretação, Richter não pintaria o que se vê, mas as estruturas que organização, os modos de apresentar todos dessacralizados. Assim, não haveria o que se encontrar ali, embora houvesse o que aprender. A pintura seria o processo de

361 SCHNECKENBURGER, Manfred. “Gerhard Richter oder ein Weg, weiterzumalen”. Em Gerhard Richter: Bilder aus den Jahren 1962-1975, Ausst. Kat. Bremen, 1975-1976.

${ }^{362}$ Citado em ELGER, Dietmar. Gerhard Richter: A Life in Painting. Chicago: University of Chicago Press, 2010. p. 167. 
problematização conceitual e institucional da linguagem. Uma linguagem onde nada parece inédito, tudo é razoavelmente trivializado ${ }^{363}$.

O argumento apresentado com ressalvas no texto de Robert Storr é importante, e talvez tenha sido hegemônico até os anos 1990, sobretudo nos Estados Unidos. No entanto, não se pergunta por que, então, Richter segue fazendo telas diferentes, encontrando novas maneiras de se replicar outros assuntos fotográficos. Não haveria um interesse de pintura aí? Um interesse afirmativo? Alguma coisa o artista procura quando realiza uma imagem, não apenas os padrões que organizam a representação ou a negação da possibilidade de se comunicar algo pela pintura. Acredito que a representação da contemplação em Betty fale sobre o que o artista encontra ao fazer a pintura, melhor: o que o artista procura.

Em um ensaio ${ }^{364}$ publicado dois anos depois do texto de apresentação de Manfred Schneckenburger, o crítico de arte Benjamin Buchloh, um dos interlocutores mais frequentes de Richter, relativiza esse argumento conceitual, embora, como Schneckenburger, aceite a menor relevância do tema. Ele entende o trabalho de Richter de até então como uma rejeição de idealismos e ideologias da tradição e da modernidade, ao se apropriar de imagens prontas ou a desidratar o gesto da pintura abstrata ao retirar dele o seu colorido.

A pintura de Richter, para Buchloh, recusaria a ideia de autoria, de originalidade, de ineditismo. No estado da arte contemporânea não haveria lugar para surtos de afirmação de uma subjetividade profunda, como na pintura informel ou nos

\footnotetext{
${ }^{363}$ Quando questionado por Irmeline Lebeer sobre isso, Richter foi enfático: "Eu não tenho interesse em denunciar coisa alguma. Fotografias aparentemente banais são as mais ricas". RICHTER, Gerhard. "Interview with Irmeline Lebeer, 1973". Em ELGER, Dietmar; OBRIST, Hans Ulrich. Gerhard Richter. Text: Writings, Interviews and Letters. Londres: Thames \& Hudson, 2009. p. 81.

${ }^{364}$ BUCHLOH, Benjamin. "Readymade, photography, and painting in the painting of Richter (1977)". Em Neo-avantgarde and Culture Industry: essays on European and American Art from 1955 to 1975. Cambridge: MIT Press, 2000.
} 
expressionismos, tampouco a promessa de novas formas de percepção. Mas algum espaço para a arte, para o artístico restaria aqui.

Pode se derivar que Richter parece procurar algum sentido positivo para a criação por trás de camadas de cópia. Aliás, algum sentido de arte autônoma. Como afirma Hal Foster, ecoando as ideias de Buchloh: "É preciso liquidar a pintura para afirmar a sua autonomia". ${ }^{365}$ A afirmação é convincente, já que para Richter: "[A pintura deve ser considerada] como uma realidade em si, sem relação com realidade alguma, exceto ela mesma".366

Ao contrário dos artistas modernos, porém, esse "mundo em si” não contrasta com as formas de representação convencional. Não se trata de um contraponto ao realmente visto. Richter reafirma os esquemas de representação como estruturas previamente dadas, independentemente de qualquer coisa. Pinta sempre a partir de um modelo, como se nunca víssemos diretamente, mas por códigos, que por vezes precisam ser anunciados, por vezes desbastados. Essa realidade em si se desvencilha da imagem fotográfica, rompendo o laço cognitivo entre a figura e seu referente.

Resta saber o que seria esse vislumbre de arte. Certamente, Richter procura alguma coisa quando começa a se valer de imagens prontas para fazer a sua figuração, para desfazer e refazer as suas pinturas abstratas o tempo todo. Há um esforço negativo de anulação de estilo, de tentativa de neutralizar as escolhas absolutamente determinadas e impositivas, mas também há o esforço para que algo surja daí.

\footnotetext{
${ }^{365}$ FOSTER, Hal. "Gerhard Richter, or the photogenic image". Em The First Pop Age. Princeton: Princeton University Press, 2012. p. 207.

${ }^{366}$ RICHTER, Gerhard. "Interview with Irmeline Lebeer, 1973”. Em ELGER, Dietmar; OBRIST, Hans Ulrich. Gerhard Richter. Text: Writings, Interviews and Letters. Londres: Thames \& Hudson, 2009. p. 79).
} 
Há alguma tentativa de afirmação, seja de uma subjetividade, de algum lirismo, da comunicação de alguma realidade, mesmo que essa tentativa não apresente promessas. Então, se tomarmos a contemplação de Betty, na pintura de 1988, alguma coisa a personagem veria lá. Mas, diferente das rückenfigur de Caspar David Friedrich, não seria algo que se ampliava, nos faria atribuir novo sentido ao mundo e, quiçá, sugeriria uma ideia da beleza divina. Em Betty, a menina olha algo muito distante, muito indeterminado, a se dissipar. Talvez seja a imagem de algo a minguar, a desaparecer, algo que uma personagem, mais sólida do que o fundo, observa, mas mal consegue capturar. A contemplação de Babette Richter seria a procura de alguma coisa por trás de uma camada de bruma escura.

Ajuda saber mais sobre a fonte da pintura. Segundo Kaja Silverman ${ }^{367}$ e Helmut Friedel, ${ }^{368}$ o fundo cinza da fotografia que serve como modelo para Betty é uma das pinturas monocromáticas feitas por Richter nos anos 1970. Silverman descreve as faixas branca e bege no canto direito da tela como pequenos indicativos da parede e do piso abaixo do monocromo.

Richter faz os primeiros monocromos em 1968. Ele desperta para esse tipo de pintura por um desejo destrutivo. O artista tentava apagar os trabalhos malsucedidos, pintando por cima deles, com uma cor que os anulasse. Usava o cinza ${ }^{369}$ por considera-lo "não cor". ${ }^{370} \mathrm{O}$ cinza não teria contrastes brutais, expressividade, tampouco brilho. Dessa

\footnotetext{
${ }^{367}$ SILVERMAN, Kaja. Flesh of My Flesh. Stanford: Stanford University Press, 2009. p. 208.

${ }^{368}$ FRIEDEL, Helmut. "Atlas: photographs, collages and sketches 1962-2006". Em RICHTER, Gerhard. Atlas. Colônia: Verlag der Buchhandlung Walter König/Nova York: DAP, 2006. p. 13.

${ }^{369}$ ELGER, Dietmar. Gerhard Richter: A Life in Painting. Chicago: University of Chicago Press, 2010. p. 219. Ele também já se referiu ao cinza como a única cor que importaria.

${ }^{370}$ Em uma entrevista de 1970, ele comenta o seu trabalho como um trabalho cuja estrutura evitaria qualquer tipo de expressividade entendida como manifestação individual, interpretação única, estilo que se contraporia à imagem ordinária. Sua escolha seria apenas do motivo e da maneira de a imagem perder o seu caráter documental. O contraponto estaria nessa identidade precária entre a fotografia e o que ela representa. Por isso, fala do cinza das impressões fotográficas em preto e branco. Segundo Richter "A não cor veio para mim da fotografia". Ela viria da tentativa de anulação de qualquer ato de expressividade reduzida. RICHTER, Gerhard. "Interview with Rolf-Gunter Dienst". Em ELGER, Dietmar; OBRIST,
} 
maneira, se Richter resolve ir à fotografia doméstica em preto e branco para evitar a composição, o estilo, o esforço de atribuir sentido voluntarista, ${ }^{371}$ resolve ir ao monocromo cinza para apagar qualquer sinal de expressividade autoral, de contrastes marcados de cor e de forma.

Aos poucos, Richter observou que o procedimento poderia ganhar, contraditoriamente, aspectos construtivos. A partir de 1972, observa as diferentes maneiras de o cinza se comportar e as propriedades de luz advindas de diferentes técnicas de pincelada. Afirmava que "de todas as cores, o cinza, só o cinza, tem a qualidade de representar nada". 372

Para Buchloh, os monocromos cinzas (124), como as pinturas feitas a partir de cartelas de cor (123), "suspenderiam o caráter autônomo e expressivo da cor". ${ }^{373}$ Os dois grupos de trabalho lidariam com uma estrutura dada, buscando um grau de variação que não permitisse dizer que houvesse uma composição por ali.

O monocromo cinza seria um tipo de pintura que ao mesmo tempo negaria dialeticamente o discurso da forma gestual para refazer uma pintura gestual não expressiva. ${ }^{374}$ Embora não fosse só uma paródia esvaziada da pintura abstrata lírica, o trabalho, para Buchloh, passava por isso. ${ }^{375} \mathrm{O}$ artista pensava que tanto a anulação completa da cor, quanto a afirmação absoluta do gesto como uma forma compositiva, pareciam algo impossível. Portanto, ele prefere andar no meio das duas categorias mutuamente excludentes. Como afirma Richter: "Cinza, como o informe e a estática

Hans Ulrich. Gerhard Richter. Text: Writings, Interviews and Letters. Londres: Thames \& Hudson, 2009. p. 54.

${ }^{371}$ RICHTER, Gerhard. “Notes, 1964”. Em ELGER, Dietmar; OBRIST, Hans Ulrich. Idem, 2009. p. 21.

372 BUCHLOH, Benjamin. "Readymade, photography, and painting in the painting of Richter (1977)".

Em Neo-avantgarde and Culture Industry: essays on European and American Art from 1955 to 1975.

Cambridge: MIT Press, 2000. p. 393.

373 Idem.

374 Idem, p. 395.

${ }^{375}$ Richter negou, em mais de uma oportunidade, qualquer sentido irônico em seu trabalho. 
[como ausência de movimento], só é real apenas como uma ideia". ${ }^{376}$ Tanto o esforço de anulação, como o de afirmação só acontecem parcialmente. O cinza, para o artista, tende a ser uma cor de cancelamento, mas não absoluto.

Richter pintaria monocromos cinza diferentes uns dos outros, como se houvesse ali uma tentativa resignada de afirmação. A pintura seria um gesto que não conseguiria mais conformar uma configuração autônoma, original, espontânea. Por mais que se esforçassem, os gestos acabariam atenuados por não se distinguirem precisamente uns dos outros. As pinceladas iam de cima a baixo, da direita para a esquerda, na horizontal, na vertical, na diagonal; podem ser retas ou curvas, abertas ou fechadas. Mesmo tentando afirmar alguma especificidade, as pinturas não constroem ritmos complexos ou direções para que a luz deslize sobre a superfície. Em alguns trabalhos se pareceriam com um novelo de pinceladas sem determinação; em outros, com meros riscos sobre uma massa homogênea.

Há monocromos e monocromos. Alguns conquistam formas fortes, mas nenhum constitui um gesto que pareça expressivo, inédito e muito menos espontâneo. Em uma entrevista, Richter diz que o único problema dos seus monocromos é serem muito bonitos. ${ }^{377} \mathrm{~A}$ ideia é de anulação: tudo seria plasmado pela mesma cor, como uma massa de movimentos que patinam e voltam para o material de origem. O cinza é uma superfície lisa ou rugosa que impede que enxerguemos além dela. Por isso, as telas em cinza não nos fazem perceber algo, mas cancelam a visão. Muitas vezes, de uma forma que tentava se diferenciar em um pântano de monotonia. Robert Storr fala desses resíduos do gesto

\footnotetext{
${ }^{376}$ Citado em STORR, Robert. Gerhard Richter: Forty years of painting. Nova York: The Museum of Modern Art, 2002. p. 44.

${ }^{377}$ RICHTER, Gerhard. "Interview with Irmeline Lebeer, 1973”. Em ELGER, Dietmar; OBRIST, Hans Ulrich. Gerhard Richter. Text: Writings, Interviews and Letters. Londres: Thames And Hudson, 2009. p. 83.
} 
de maneira mais clara. O conceito de entropia será central para a interpretação daqui em diante:

Richter não estava obliterando a representação com abstração, mas, ao invés disso, começando com uma tela vazia, ele tentava simultaneamente retratar a negação e a plenitude, tentando dar-lhes uma definição substancial na esperança de prevenir entropia. $\mathrm{O}$ fato de que as pinturas são manifestamente diferentes entre si - não só nos aspectos mais óbvios do formato ou da técnica, mas também na fatura individual - confirmaram a estratégia de Richter, embora demorasse um pouco para ele ter plena confiança de que isso era verdade. ${ }^{378}$

Tal descrição talvez servisse para o que Betty procura por detrás do fundo escuro. Quando é pintado à óleo, como uma figura em Betty, o monocromo é convertido em fundo da tela. Richter atenua as marcas de profundidade e sombreamento ao pintar a fotografia. O fundo é tão encoberto que não há mais nada ali para se identificar. Se houve, desapareceu. Não é que ele tenha se transformado, mas perdeu-se de vista. A pintura torna-se um pano de fundo que ao mesmo tempo sugere ser intransponível, mas por conta da sua luz também é atmosférico. É para lá que o olhar da menina se dirige.

Os olhos de Betty Richter encaram um plano escuro, mal definido, esfumaçado, impalpável, monocromático. Nada ali se forma, se diferencia. É uma bruma vazia onde tudo se dispersa. Cor, figura, forma e gesto são expulsos. Assim, a menina olha para o nada, para uma entropia absoluta. ${ }^{379}$

\footnotetext{
${ }^{378}$ STORR, Robert. Gerhard Richter: Forty years of painting. Nova York: The Museum of Modern Art, 2002. p. 57.

379 No mesmo ano em que fez a pintura, Richter pintou uma fotografia colorida da sua filha já adulta (120), que parece inverter a perspectiva de Betty (1988). No trabalho, a exuberância do colorido vê a mulher (que olha na direção da câmera) desvanecer.
} 
Tal como nas pinturas abstratas, a contemplação da personagem na tela se detém naquele vácuo vazio, como se ainda pudesse reter algo. A promessa de que qualquer coisa possa ser capturada ali é o que talvez dê um tom relativamente otimista à tela. Ainda que nada tenha se apresentado, uma luz, ao redor da cabeça de Betty, sugere acanhada que algo pode se formar. A observadora persiste. Mesmo sabendo que ela provavelmente se esquecerá de tudo o que viu.

\section{Ruínas}

Em 1976, Gerhard Richter passou a priorizar as pinturas abstratas. A produção figurativa tornou-se mais episódica. Quando pintava fotografias, o artista fazia séries ou pinturas de gênero, como naturezas-mortas, retratos, paisagens, vanitas. Procurava assuntos de pintura muito codificados nas cenas fotografadas que reproduzia em suas telas. A sobreposição que era feita entre tema, fotografia do tema (pensado como um esquema supostamente neutro de descrição) e cópia da fotografia em tinta a óleo, nas fotopinturas, é transferido para o método de realização das pinturas abstratas informais. Nessa obra gestual, sobretudo a partir da década de 1980, Richter desenvolveu uma técnica, com a qual fazia e desfazia relações de campos de cor, até que a composição inicial se tornasse irreconhecível (126 e 127).

O procedimento dessas telas abstratas gestuais possui alguns passos essenciais. Primeiro, Richter ocupa o espaço de maneira irregular com um número limitado de cores, três ou quatro cores muito diferentes umas das outras. Ele delimita a área de cada uma delas, atribuindo um espaço generoso a essas primeiras camadas de tinta aplicadas na superfície. Antes das cores secarem, Richter pincela sobre elas, desfazendo os limites e misturando uma na outra pelo gesto. Atua assim até que as formas percam sua definição e sua homogeneidade. O verde aparece sobre o vermelho e se mistura ao 
azul. Começamos a ver cores terciárias, indefinidas, surgirem em meio aos gestos do artista.

As cores são pinceladas, espatuladas, criando um plano indistinto, com massas encobrindo os restos de gesto e cor aqui e ali. Boa parte da tela passa a ser ocupada por massas indistintas e heterogêneas. Não obstante, os gestos ficam marcados. O artista passa uma espátula sobre esses gestos, desfazendo-os. O artista pinta sobre essa massa, raspa-a mais algumas vezes, cobre com outra cor, raspa de novo, até que qualquer possibilidade de desígnio dos seus gestos desapareça. No fim, a pintura parece feita de cacos das diversas pinturas anteriores, uma sobre a outra como uma pilha indistinta de resíduos de outras pinturas. Não conseguimos mais identificar a arquitetura íntegra de nenhuma das pinturas que foram feitas anteriormente, mas sobram muitos vestígios (127 e 139): camadas e camadas de pintura soterradas umas nas outras.

Desde 1980, Richter usa o rodo como forma de deslocar massas de tintas e atribuir à superfície um tratamento liso, desfocado. Não por acaso, uma de suas séries mais importantes se chama Courbet (125-126), pintor do espatulado. A pintura é massuda, mas possui texturas diferentes em cada camada. Em Gelo (2) (139), de 1989, uma camada branca mais acidentada, translúcida, cobre uma massa irregular e lisa de azuis, amarelos e cinzas. Essa camada, como a branca, é esburacada. Nos vãos, vemos manchas vermelhas brilhantes. Uma camada deixa ver a outra.

O trabalho do artista parece retirar os vínculos comunicativos e semânticos das formas e dos gestos originais. No caso das pinturas abstratas, vemos resíduos do que a pintura poderia ter sido. Não há mais pistas do que foi a "composição" anterior, sobraram só os seus cacos. Os pedações são visíveis, mas soterrados uns nos outros. Como se a tela fosse um conjunto de ruínas de modos de organização da cor anteriores. Quanto mais se pinta, mais se destrói. Até que sobre alguma coisa, algum resíduo, alguma pintura. 
Quando Richter pinta através de fotografias, ele também sobrepõe modos de organização da imagem. Ele age por acumulo, seja de trabalho pictórico, seja de descrição, seja de mediações. Como sintetiza Gertrude Koch:

Richter tenta apagar os sinais históricos precisos indicados pelas fotografias, para apagar a sua presença. (...) a destruição planejada de todo significado fornece a justificativa para seu próprio significado específico em termos de uma estética da negatividade. ${ }^{380}$

Em outros termos, o assunto do trabalho de Richter não é tanto o que a imagem nos conta, mas o que ela passa a contar depois de refeita, apagada, pintada com indeterminação. $\mathrm{O}$ artista parece pensar a sua produção da mesma forma que se pensava a pintura informel no começo dos anos 1960. Ao pintar, ele desfaz a capacidade comunicativa da fotografia. Em algum grau, sobra dela uma ruína.

Quanto mais pinta, mais apagadas e indeterminadas as descrições parecem. Isso serve para os quadros figurativos e também para os abstratos. Sua pintura, invertendo a reprodutibilidade fotográfica, ao tornar a imagem um objeto único, parece dar razão à máxima quase antifotográfica de Siegfried Kracauer: ${ }^{381}$

A obra de arte também se desintegra com o tempo, mas o seu significado aflora dos seus elementos decompostos enquanto a fotografia acumula os elementos. ${ }^{382}$

\footnotetext{
${ }^{380} \mathrm{KOCH}$, Gertrud. "The Richter-Scale of Blur". Em BUCHLOH, Benjamin H. D. (Org.) Gerhard Richter (October Files). Cambridge: MIT Press, 2009. p. 42.

${ }^{381}$ Segundo Kracauer, a fotografia é um instrumento de amnésia social: “A fotografia é o sedimento depositado pelo monograma e ano após ano diminui o seu valor de signo. O teor de verdade do original se retém na sua história; a fotografia retém o resíduo do qual a história se despediu". KRACAUER, Siegfried. "A fotografia”. Em Ornamento da Massa. Trad. Carlos Eduardo Jordão Machado e Marlene Holzhausen. São Paulo: Cosac Naify, 2009. p. 72.

382 Idem, p. 69.
} 
A pintura para Richter acontece quando perdemos todo o resto de vista.

Em 1968, Richter foi convidado para fazer uma fotopintura no escritório italiano da Siemens, uma das maiores corporações alemãs, em Milão. A encomenda o anima a pintar uma série de vistas urbanas (131-136). A série As paisagens urbanas (1968-1969) se desdobra em mais de uma dezena de quadros. Os trabalhos partem de fotografias aéreas, panorâmicas, como o Bird-eye-view de Bruegel. A cidade vista de cima não é retratada do ponto de vista do projeto ordenado, como as cidades desenhadas pelos artistas construtivos, mas de imagens distantes, que parecem a vista aérea dos caças e bombardeios da Segunda Guerra Mundial, pintados por Richter logo no início de sua carreira. Talvez por isso, o resultado do trabalho, muitas vezes, nos remeta não para a imagem de uma cidade acabada, mas para a imagem de uma ruína.

Ao longo dos trabalhos, o artista escolhe pintar cada fotografia (137) de uma forma. Em Paisagem de Paris (131), o panorama é pintado com pinceladas curtas, curvas, soltas, irregulares e pastosas. ${ }^{383}$ Uma mancha desfaz a outra, perde a definição, desfaz os contornos. O prédio perde a solidez. Tudo parece informe, desmoronado nas telas. A vista final faz o próprio Richter se lembrar das ruínas de Dresden logo depois da guerra. ${ }^{384} \mathrm{E}$ uma cidade vazia, destruída, feita de escombros sobre escombros. Há dejetos na imagem, não é possível reencontrar a cidade. Como não é possível narrar nada sobre a destruição.

\footnotetext{
${ }^{383}$ ELGER, Dietmar. Gerhard Richter: A Life in Painting. Chicago: University of Chicago Press, 2010. p. 165.

${ }^{384}$ O próprio Richter disse: "Quando revejo agora as Paisagens Urbanas, elas me lembram algumas imagens da destruição de Dresden durante a guerra". RICHTER, Gerhard. "Comments on Works (1991) ". Em ELGER, Dietmar; OBRIST, Hans Ulrich. Gerhard Richter. Text: Writings, Interviews and Letters. Londres: Thames \& Hudson, 2009. p. 262.
} 
Mesmo quadros mais organizados e lineares como Stadtbild TR, de $1969,{ }^{385}$ lidam com essa fragmentação, ${ }^{386}$ essa impossibilidade de restituir uma imagem íntegra ao tecido urbano. A integridade não é rompida pelo gesto ou pela matéria, mas pelo desencontro das telas justapostas. Feita com três painéis, a pintura parece não acertar uma unidade precisa, bem amarrada. É uma cidade fraturada, onde um fragmento não se junta como o outro.

Coincidência ou não, as imagens das cidades aparentadas com ruínas foram feitas quando a estabilidade da Europa do pós-guerra era contestada violentamente nas ruas. As revoltas de 1968 tinham um precedente alemão. Em 1967, as manifestações estudantis demonstraram a truculência e a indiferença das autoridades alemãs com a morte de Benno Ohnesorg durante os protestos contra a visita do Xá do Irã a Berlim.

Mark Godfrey compara as Paisagens Urbanas de Richter com imagens construtivas da cidade modernista. Ao contrário de El Lissitsky, Richter não atribui à imagem da cidade "uma invocação do dinamismo utópico do modernismo". ${ }^{387}$ As cidades aqui são ou constituídas por blocos isolados, sem comunicação de prédios, ou por cidades devastadas.

A reconstrução das cidades alemãs depois da guerra pode ser pensada como uma metáfora de sua relação com o traumático passado nazista. Segundo W.G. Sebald, a derrota alemã e sua desmoralização parecem incomparáveis à arrogância de antes da guerra. Segundo o escritor:

\footnotetext{
${ }^{385}$ T.J. Clark identifica o germe das questões que Luc Tuymans desenvolvera anos depois neste trabalho. CLARK, T.J. "Grey Panic". London Review of Books v. 33, n. 22, do dia 17 de novembro de 2011. p. 37. Disponível em: http://www.lrb.co.uk/v33/n22/tj-clark/grey-panic.

${ }^{386}$ Richter fala do "senso de descontinuidade" entre as pinturas e as imagens nessa série. RICHTER, Gerhard. "Comments on Works (1991)". Em ELGER, Dietmar; OBRIST, Hans Ulrich. Gerhard Richter. Text: Writings, Interviews and Letters. Londres: Thames \& Hudson, 2009. p. 263.

${ }^{387}$ GODFREY, Mark. "Damaged Landscapes". Em GODFREY, Mark; SEROTA, Nicholas. Gerhard Richter: Panorama. Londres: Tate, 2011.
} 
É difícil fazer hoje uma ideia, mesmo que aproximada, da medida da devastação das cidades alemãs ocorrida durante os últimos anos da Segunda Guerra Mundial, e ainda mais difícil pensar sobre os horrores a ela associados. É certo que consta nos Strategic bombing surveys dos Aliados, nos levantamentos do Departamento Federal Alemão de Estatísticas e em outras fontes oficiais, que apenas a Royal Air Force lançou, em 400 mil voos, 1 milhão de toneladas de bombas sobre a zona inimiga; que, das 131 cidades atingidas — umas só uma vez, outras repetidas vezes -, algumas foram quase totalmente arrasadas; que a guerra aérea deixou em torno de 600 mil vítimas civis na Alemanha; que 3,5 milhões de residências foram destruídas; que, no final da guerra, havia 7,5 milhões de desabrigados; que, em Colônia, a cada habitante correspondiam 31,4 metros cúbicos de escombros e, em Dresden, 42,8 — mas, mesmo assim, não sabemos o que tudo isso significava de verdade. A ação de aniquilamento, até então sem par na história, ingressou nos anais da nação que se reconstituía apenas em forma de generalizações vagas e parece mal ter deixado um vestígio de dor na consciência coletiva, permanecendo amplamente excluída da experiência retrospectiva pessoal daqueles por ela afetados. ${ }^{388}$

Assim, a maneira de lidar com tamanha destruição foi construir uma imagem heroica da reconstrução das cidades alemãs. ${ }^{389}$ Sebald acredita que:

O verdadeiro estado da destruição material e moral em que o país inteiro se encontrava não podia ser descrito em virtude de um acordo tácito e

\footnotetext{
${ }^{388}$ SEBALD, W.G. Guerra aérea e literatura. São Paulo: Companhia das Letras, 2011. Trad. Carlos Abbenseth e Frederico Figueiredo. p. 13-14.

${ }^{389}$ Idem, p. 21-23.
} 
válido igualmente para todos. Os aspectos mais sombrios do ato final da destruição, vivenciado em conjunto pela ampla maioria da população alemã, permaneceram um segredo familiar tão vergonhoso, submetido a uma espécie de tabu, que não se podia confessá-lo, quiçá, nem a si próprio. 390

A série das Paisagens urbanas de Richter, como de resto, todo o seu trabalho, parece lidar com a dificuldade de encarar a tragédia que se revelaria por trás de uma autoimagem da negação. A maneira de pintar as vistas de metrópoles coloca o quadro em desacordo com as imagens de que ele partiu. Qualquer sentido ideológico, pacificador, parece ser desfeito aí. Como em outras fotopinturas, o trabalho lida com esse desencontro. Ao pintar uma fotografia, o artista desloca essa imagem do seu campo de significação e retira dela as suas marcas históricas de distinção.

As imagens que servem como referência para Richter, no mais das vezes, prometem um encontro conciliador de quem observa com o que é apresentado. Esse levantamento de informações permite que finjamos entrar em contato com uma realidade sobre a qual mal conseguimos nos pronunciar. É sobre isso que as pinturas de Gerhard Richter elaboram a sua reflexão. Sobre a esperança de reviver a violência da tragédia e a alegria das promessas. Entendo que para ele a arte lida com o desencontro em relação a essas promessas.

Não por acaso, o artista tentou mais de uma vez representar alguma imagem sobre o trauma do Holocausto. Em 1967, enquanto pintava imagens retiradas de revistas pornográficas, tentou realizar alguma coisa com as imagens dos campos de concentração

\footnotetext{
${ }^{390}$ Idem, p. 19.
} 
que colecionava. ${ }^{391}$ As imagens eram explícitas demais, traumáticas demais. O artista não conseguiu transformar aquilo em pintura. Na década de 1990, quando foi convidado a ocupar uma das paredes do saguão do Reichstag em Berlim, pensou em ocupá-la também com essas imagens.

O projeto não foi para frente. Richter acabou entregando um painel abstrato com as cores da bandeira alemã. Incomodou-lhe o tom discursivo do projeto sobre o Holocausto. Parecia-lhe apelativo e sensacionalista. ${ }^{392} \mathrm{O}$ artista abandonou mais uma vez o tema, como já havia feito antes.

Em 1988, quando pintou a série sobre a morte dos integrantes da RAF, o artista já pensara pintar sobre o trauma alemão, de uma sociedade não integralmente resolvida com o passado nazista e as promessas ideológicas naquela tela.

Richter pensou em quinze telas, de tamanhos diferentes, como um trabalho só, feito para uma exposição individual realizada em Krefeld. A princípio, o artista não pensava nem mesmo em vender as pinturas. Elas talvez sejam o momento de maior ambição temática das pinturas de Richter.

A RAF foi um grupo terrorista, extremista e niilista. A princípio, estava ligada à chamada oposição extraparlamentar alemã, mas aos poucos entra em uma espiral de radicalização e perde a relação com os militantes desarmados. Três dos seus líderes morreram no dia que dá nome à série, sob a custódia das autoridades alemãs, no presídio de Stammheim. Embora o grupo tenha durado ainda muitos anos, cada vez mais violento e niilista, as mortes simbolizaram também o fim de muitas promessas do século XX.

\footnotetext{
${ }^{391}$ Folhas 16 a 20 do Atlas (da série Fotografias dos livros). Cf. RICHTER, Gerhard. Atlas. Colônia: Walter König e Helmut Friedel/ Nova York: DAP, 2006.

392 Cf. ELGER, Dietmar. Gerhard Richter: A Life in Painting. Chicago: University of Chicago Press, 2010. p.336.
} 
As utopias comunistas revividas pelos grupos estudantis da Alemanha Ocidental não repetiam a história como farsa, mas como tragédia. Voltavam-se contra si mesmas em um processo de endurecimento da autoridade e de violência sem sentido dos grupos revolucionários. Além disso, as promessas de civilidade e do fim da macabra indiferença à vida do Estado alemão também eram colocadas sob suspeita. Como antes, as promessas ideológicas deixavam um rastro sangrento em seu caminho. Segundo Richter, a série comentava o fracasso de se tentar mudar a história. ${ }^{393}$ Embora Richter não tivesse simpatia nenhuma pelos ideários do grupo, se compadeceu com a situação desesperadora e o aspecto fatal das certezas históricas.

Na época em que Richter mostrou os trabalhos, a RAF ainda operava e os familiares dos personagens envolvidos nas tragédias estavam atentos às repercussões do caso. Não era a primeira vez que a arte tratava dos anos de chumbo, algumas representações, como os filmes Alemanha no outono (Deutschland im Herbst), ${ }^{394}$ Anos de Chumbo (Die Bleierne Zeit), ${ }^{395}$ Terceira Geração (Die Dritte Generation), ${ }^{396}$ aconteceram quando o grupo estava ativo e ocupava as manchetes de jornais. Nas artes

\footnotetext{
${ }^{393}$ RICHTER, Gerhard. "Interview with Gregorio Magnani, '1989”'. Em ELGER, Dietmar; OBRIST, Hans Ulrich. Gerhard Richter. Text: Writings, Interviews and Letters. Londres: Thames \& Hudson, 2009. p. 221.

${ }^{394}$ Filme coletivo de 1978, dirigido por Rainer Werner Fassbinder, Alf Brustellin, Alexander Kluge, Maximiliane Mainka, Beate Mainka-Jellinghaus, Peter Schubert, Bernhard Sinkel, Hans Peter Cloos, Edgar Reitz, Katja Rupé, Volker Schlöndorff. Escrito por Rainer Werner Fassbinder, Alf Brustellin, Heinrich Böll, Hans Peter Cloos, Alexander Kluge, Maximiliane Mainka, Beate Mainka-Jellinghaus, Edgar Reitz, Katja Rupé, Volker Schlöndorff, Peter Schubert, Bernhard Sinkel, Peter F. Steinbach. ${ }^{395}$ Filme de Margarethe von Trotta, de 1981.

${ }^{396}$ Filme de Rainer Werner Fassbinder, de 1979.
} 
plásticas, Joseph Beuys, ${ }^{397}$ Wolf Vostell (92) e Yvone Rainer ${ }^{398}$ haviam tratado da guerrilha e da repressão policial. Mesmo assim, 18 de outubro de 1977 (70-91), a série de Richter, causou muita controvérsia. ${ }^{399}$

Richter partiu de imagens feitas na prisão, nos tribunais e durante a vida dos militantes. A sua maior fonte foi a revista Stern. O artista escolheu as imagens, aliás, dezenas delas, fotografou-as em seu estúdio e as fez mais indefinidas, mais desfocadas que as versões originais. Richter desfocava e reduzia o colorido das imagens. Depois de pintada, a cena era borrada por pinceladas regulares, sempre na mesma direção, que retiravam a definição do contorno das figuras e reforçavam o aspecto evanescente da imagem.

Nas pinturas de Richter, a imagem desses episódios do chamado Outono alemão não é permeada por heroísmo, complacência ou pela marca de alguma direção histórica nova. Ali, como nas vistas do bombardeio a Dresden, em 14 de fevereiro de 1945, tudo é ruína.

As figuras parecem se dissipar, perdendo a sua definição, suas particularidades, apodrecendo como carne morta. A opacidade da pintura é pensada como a dificuldade de encontrar o que é representado. Pior que isso, a dificuldade de recuperar aquela história, de definir os papéis de cada um. Ninguém retém nada. Não há o esforço

\footnotetext{
397 Joseph Beuys fez uma escultura e sugeriu a ação "Dürer, ich führe persönlich Baader + Meinhof durch die Dokumenta V”, em 1972. A suposta ação seria feita com Thomas Peiter, que percorreria a Documenta de Kassel fantasiado de Albrecht Dürer. Beuys realizava a performance em que discutia democracia direta por 100 dias com os visitantes da exposição. Durante um dos debates, pronunciou a frase que deu nome aos trabalhos: "Dürer, eu guiarei pessoalmente os membros do Baader-Meinhoff pela Documenta V, então eu os reabilitarei". Cf. STORR, Robert. Gerhard Richter: October 18, 1977. Nova York: The Museum of Modern Art, 2000. p. 68; e MESCH, Claudia. "Institutionalizing social sculpture: Beuys" Office for Direct Democracy through Referendum installation (1972). Em MESCH, Claudia; MICHELY, Viola Joseph Beuys: the reader. Londres/Nova York: I.B. Tauris, 2007. p. 208.

${ }^{398}$ A coreógrafa, performer e cineasta experimental fez o curta-metragem em $16 \mathrm{~mm}$. Journeys from Berlin/1971 (1980). Disponível em: https://www.youtube.com/watch?v=EppiqMhojOs.

${ }^{399}$ Cf. STORR, Robert. Gerhard Richter: October 18, 1977. Nova York: The Museum of Modern Art, 2000; e ELGER, Dietmar. Gerhard Richter: A Life in Painting. Chicago: University of Chicago Press, 2010. p. 281-310.
} 
heroico como o atribuído a Marat em um retrato de martírio de Jacques Louis David. Aqui tudo perde o sentido. Aliás, o gesto do suicídio ou assassinato dos membros da RAF não transforma nada. É uma tragédia em estado de entropia.

Antes de continuar, é importante lembrar que mesmo que não tenha conseguido pintar o Holocausto até então, Richter pintara o nazismo. Inclusive nos retratos de família. A imagem do seu orgulhoso e sorridente Tio Rudi (103), em meio a um cenário vago e manchado é a imagem de um oficial da Gestapo em uma situação comum. Uma imagem do horror da vida do dia a dia. A tela faz par com Tia Marianne (1965) (104), imagem da tia de Richter, eliminada nos programas de eugenia nazista, com ele no colo.

Eis que em 2014, Richter, na época um senhor de 82 anos de idade, resolve retomar o tema do Holocausto. Faz a série de pinturas chamada Birkenau (140-143). A série é mostrada pela primeira vez em Dresden, no Museu Albertinum (que abriga o arquivo de Richter), por circunstância dos 70 anos de libertação dos campos de Auschwitz-Birkenau pelas tropas aliadas, em janeiro de 1945.

Os trabalhos que Richter tentou fazer sobre o Holocausto anteriormente, tinham sido pensados a partir de fotografias feitas por soldados aliados no dia da liberação dos campos. O trabalho que realizou partiu das imagens divulgadas por Georges DidiHuberman no livro Imagens, apesar de tudo. ${ }^{400}$ No livro, Didi-Huberman comenta quatro fotografias que seriam a única representação fotográfica existente dos campos de concentração capturadas pelas próprias vítimas. Como afirma Benjamin Buchloh, "Seriam os arquivos sobreviventes" do testemunho dos judeus aprisionados. ${ }^{401}$ Richter vê

\footnotetext{
${ }^{400}$ DIDI-HUBERMAN, Georges. Images in spite of all. Chicago: University Chicago Press, 2008. Originalmente: Images malgré tout. Paris: Minuit, 2004.

${ }^{401}$ BUCHLOH, Benjamin. "Amnesia and Anamnesis". Em RICHTER, Gerhard; BUCHLOH, Benjamin. Gerhard Richter Bikernau Paintings. Colônia: Verlag der Buchhandlung Walther König, 2016. p. 21.
} 
essas imagens pela primeira vez na edição de 11 de fevereiro de 2008 do jornal Frankfurter Allgemeine Zeitung. Elas ilustravam uma resenha do livro de DidiHuberman.

Embora Richter projete as imagens na tela e comece a trabalhar a partir delas, a configuração final das pinturas pouco lembra o motivo inicial. Ele faz quatro telas do mesmo tamanho, pintadas da mesma maneira. ${ }^{402}$ Richter desenha as fotografias projetadas na tela como fotopinturas e começa a adicionar camadas como se tentasse cancelar a imagem. Usa um colorido muito simples: a primeira demão é feita em um corde-rosa opaco que mal cobre a superfície figurativa. A tinta é aplicada na horizontal e espatulada na vertical. Depois de retirar todo o excesso de rosa, a cena continua a aparecer para nós. O artista tenta cobrir com pinceladas vermelhas na horizontal. Ele cobre os buracos com tinta verde na horizontal. Sobre essa massa, pincela até que as definições desse gradeado desapareçam. Aí, tenta isolar tudo que seja reconhecível com pretos, brancos e cinzas. Por traz dessas camadas, alguma coisa da imagem original persiste. Mas não chega a ser identificável. O que sobra são pequenos espaços vazios por trás de camadas e camadas de pintura.

Segundo Benjamin Buchloh, Richter prefere figurar a dificuldade de representar e alcançar essa tragédia do que transformá-la em espetáculo. ${ }^{403} \mathrm{~A}$ configuração final do quadro seria mais sobre a dificuldade de lidar com a tragédia do que uma denúncia ou um teatro do sofrimento humano. O crítico contrapõe sua

\footnotetext{
402 O catálogo mostra o procedimento do artista passo a passo: RICHTER, Gerhard; BUCHLOH, Benjamin. Gerhard Richter Bikernau Paintings. Colônia: Verlag der Buchhandlung Walther König, 2016. p. 29-38.

${ }^{403}$ Idem, p. 22.
} 
interpretação do trabalho de Richter às formas de restaurar criticamente uma iconografia germânica. Aqui, retoma a diferença modernista entre vanguarda e kitsch. ${ }^{404}$

Na década de 1960, o pintor Georg Baselitz disse que Richter era um traidor da pátria. ${ }^{405}$ Baselitz, àquela altura, tentava restaurar uma iconografia expressionista, como uma busca da liberdade artística pós-nazismo. Dizia que Richter adotava formas de representação "internacionais" em vez de tentar restaurar uma iconografia alemã, devastada pelo nazismo. No entanto, a pergunta que a obra de Richter parece fazer é: o que há para ser restaurado?

Baselitz, como outros pintores do neoexpressionismo alemão, pretendia reconstruir uma cultura da rebeldia alemã anterior ao nazismo. Voltava-se para uma iconografia germânica, feita a partir de mitos e significados culturais teutônicos, que buscava restaurar uma cultura de resistência local, mesmo contra qualquer hegemonização internacionalista. ${ }^{406}$

A produção de Baselitz implicava uma reafirmação do trabalho artesanal, uma reafirmação de especificidades perdidas. A cura do pesadelo nazista viria a partir de uma identidade interrompida, espontânea e supostamente contestadora. O que se buscava era uma restauração romântica da identidade cultural como substituto para o nacionalismo xenófobo nazista.

Encenações românticas desse tipo acabam por converter a recusa em afirmação. Como bem lembra Benjamin Buchloh, em nome de uma suposta transgressão,

\footnotetext{
${ }^{404}$ BUCHLOH, Benjamin. "Readymade, photography, and painting in the painting of Richter (1977)". Em Neo-avantgarde and Culture Industry: essays on European and American Art from 1955 to 1975. Cambridge: MIT Press, 2000.

${ }^{405}$ RICHTER, Gerhard. "Moma Interview with Robert Storr, 2002”. Idem, p. 400.

${ }^{406}$ Cf. BOIS, Yve-Alain; BUCHLOH, Benjamin H.D.; FOSTER, Hal; KRAUSS, Rosalind. Art since 1900. Modernism, antimodernism, postmodernism. Londres: Thames \& Hudson, 2004. p. 477.
} 
restauram-se uma série de proibições. ${ }^{407}$ Um estilo que se torna mais uma marca de autoria, uma especificidade mercantil do que a superação da cultura. Seria mais uma reinvenção espetacularizada da figura do artista excêntrico, sem amarras, prestes a reconstruir a autenticidade em uma cultura decadente. Em certo sentido, parece a figura do "crítico da cultura" pensada por Adorno em Crítica cultural e sociedade: o sujeito que crítica a cultura para salvá-la. ${ }^{408}$

O que talvez aprendamos com o trabalho de Richter é que tais encenações históricas de uma cultura ao mesmo tempo rebelde e passadista parecem impossíveis e, pior, falaciosas. O gesto liberado para imaginar de alguns pintores neo-expressionistas dos anos 1980 parece mais reviver um clichê do que escapar do convencionalismo e das modas internacionais. A pintura de Richter parece tratar dessa impossibilidade da subjetivação pelo estilo. A impossibilidade de desfazer e restaurar a cultura. A impossibilidade de transformações deliberadas.

A pintura de Richter mostra a impossibilidade de as descrições restaurarem qualquer experiência ou o passado. Sempre que a pintura lida com o tempo, lida com o irrecuperável. A descrição nunca se concilia com o que é descrito. A arte parece representar essa distância, essa dificuldade. A arte não promete nada além de colocar algo diante de nós. Algo que contemplamos de longe, mas jamais conseguiremos tocar.

\footnotetext{
${ }^{407}$ Idem, p. 478; e BUCHLOH, Benjamin. "Figures of Authority, Ciphers of Regression. Notes on the return of the return of representation in the European painting". Em Formalism and Historicity: Models and Methods in Twentieth-Century Art. Cambridge: MIT Press, 2015.

408 "Enquanto avaliador, o crítico da cultura tem inevitavelmente de se envolver com uma esfera maculada por valores culturais, mesmo quando luta zelosamente contra a mercantilização da cultura. Em sua atitude contemplativa em relação a ela, introduz-se necessariamente um inspecionar, um supervisionar, um pesar, um selecionar: isto lhe serve, aquilo ele rejeita. Justamente sua soberania, a pretensão de possuir um conhecimento profundo do objeto, a separação entre o conceito e seu conteúdo através da independência do juízo, ameaça sucumbir à configuração reificada do objeto, na medida em que a crítica cultural apela a uma coleção de ideias estabelecidas, fetichizando categorias isoladas como "espírito", "vida" e "indivíduo". ADORNO, Theodor. "Crítica cultural e sociedade". Em Prismas: crítica cultural e sociedade. São Paulo: Ática, 1998.
} 


\section{CONSIDERAÇÕES FINAIS}

Era para ter sido melhor que os outros o nosso século XX.

Agora já não tem mais jeito, os anos estão contados, os passos vacilantes, a respiração curta.

Coisas demais aconteceram, que não eram para acontecer, e o que era para ter sido não foi. ${ }^{409}$

(WISLAWA SZYMBORSKA)

${ }^{409}$ Duas primeiras estrofes do poema "Ocaso do século", publicado originalmente em 1987. Em SZYMBORSKA, Wislawa: Poemas, Tradução de Regina Przybycien. São Paulo, Companhia das Letras, 2014 (p. 75). 
$\mathrm{Na}$ segunda metade do século $\mathrm{XX}$, as formas de representação visual se transformam. Com mudanças técnicas e políticas, a imagem dos meios de comunicação de massa se torna onipresente. Nas grandes cidades dos países mais ricos do capitalismo ocidental, já nos anos 1960, as representações da cultura de massa parecem permear toda a experiência social. Através de sua intermediação, as pessoas passam a entender os acontecimentos históricos, a vida sentimental, as guerras, os espetáculos esportivos, o consumo cultural e os embates políticos. Diante de tamanha hegemonia, as artes visuais se põem a pensar esse novo sistema de produção de imagens.

Alguns artistas insistem na especificidade da arte versus a indústria cultural. A criação artística seria uma barricada de resistência contra as simplificações codificadas e reducionistas. Os artistas deveriam exigir de si mesmos uma reflexão mais densa e complexa. Alguns vão lidar com essas formas de representação como uma inevitabilidade. A imagem da arte teria sido fagocitada por um regime muito mais abrangente do que qualquer outro artefato cultural anterior.

Andy Warhol e Gerhard Richter são alguns dos primeiros artistas a tratar essa difusão de imagens como uma questão estética. Para eles, lidar com esses meios é inevitável. Esse novo regime visual é uma condição dada. Na obra de ambos, a arte não se distingue substancialmente das formas mais banais de representação. A criação se dá a partir das linguagens dadas por esses novos meios. Warhol e Richter manipulam esse universo de signos reconhecíveis que se colocam entre nós e o mundo. Na produção deles, a pintura fica mais parecida com as imagens fotográficas do que parecida com uma imagem artística. 
De maneira mais ou menos desencantada, e muito diferentes, Richter e Warhol vão equivaler as formas da história da arte com as outras formas de representação visual. Com consciência dos limites de ação da obra de arte, em um meio em que a representação histórica foi tomada de assalto, o esforço abre outras possibilidades criativas.

Em 1977, Cindy Sherman inicia a série de Film Stills. Nesse trabalho, a artista simulava as cenas semelhantes às imagens de divulgação dos filmes. Eram fotografias capturadas no set de filmagem, enquanto as cenas eram rodadas. Caso fossem tiradas em outro momento, mostrava o elenco encenando como se estivesse no filme. A articulação de signos do estrelato continua um caminho aberto por Andy Warhol.

Os stills não possuíam qualidades que os distinguisse especialmente. Tinham como função capturar a atmosfera dos filmes que promoviam e divulgavam. As imagens apresentavam as estrelas e tentavam, de maneira sedutora, convencer o espectador a comprar um ingresso. Era propaganda pura e simples. As fotografias ficavam na porta das salas de cinema, eram publicadas nas revistas e nos jornais, por vezes colecionadas pelos aficionados.

A partir desse material, Sherman começa a criar personas e a elaborar a miseen-scène das imagens. As fotografias retratavam uma personagem feminina, em preto e branco, aparentada com personagens do cinema americano e europeu das décadas de 1950 e 1960. Nas imagens, só a artista aparecia. Ela encenava um papel por foto. Em sua atuação, não criava apenas as personagens, mas também as atrizes que davam vida às personagens. ${ }^{410}$ Ela mesma diz que, no início do trabalho,

\footnotetext{
410 “As personagens não eram bobas; elas não eram apenas atrizes cabeças-de vento. Eram mulheres lutando contra algo, mas eu não sabia o quê." Cf. SHERMAN, Cindy. "The Making of Untitled". Em The Complete Film Stills. Nova York: Museum of Modern Art, 2003. (p. 09)
} 
queria fazer um grupo de stills imaginários, todos da carreira da mesma atriz. Nessas primeiras fotografias, o cabelo não muda tanto, acho que a fiz uma loira, porque isso parecia mais teatral e talvez porque eu ainda tivesse cabelos castanhos. Eu não sabia o que eu estava fazendo no momento, na verdade, eu encenava. Eu tentei torná-la mais velha em alguns stills, mais ingênua em outros, e com alguma idade - fazendo de tudo para parecer mais jovem em outros. Eu não pensei sobre o que cada filme tratava, eu me concentrei nas diferentes idades e aparências do mesmo personagem. ${ }^{411}$

O trabalho era uma encenação dupla. Ao longo dos anos em que Sherman realizou essa série, algumas personagens reapareceram em outros contextos, a desempenhar outras ações. Assim como as mesmas fisionomias, cabelo e maquiagem aparecem na pele de outras personagens.

Nos stills 1 a 6 (146-151), Sherman aparece com a mesma peruca, a mesma expressão em situações muito diferentes. Seria de supor que aquela mulher loira, com o corte de cabelo Chanel, com franja, fosse a mesma atriz desempenhando papeis diferentes. O procedimento era recorrente; algumas "atrizes" encarnavam personagens distintas mesmo em fotografias separadas por mais de um ano (153-154).

Como tudo era muito familiar, era possível pensar que Cindy Sherman replicava as cenas de filmes conhecidos. As fotografias variavam o formato, mas não eram grandes. Possuíam o mesmo tamanho que os stills afixados nos displays. As personagens lembravam não sei qual atriz, não sei qual personagem. Algumas cenas

\footnotetext{
${ }^{411}$ Idem, p. 7.
} 
lembravam imagens de diretores como Billy Wilder, Frank Capra, Michelangelo Antonioni, do cinema noir $^{412}$ e os melodramas de Douglas Sirk. ${ }^{413}$

Muitos outros filmes parecem ser "citados" nas fotografias de Cindy Sherman. Kaja Silverman faz um longo inventário de semelhanças. ${ }^{414}$ Os stills de Cindy Sherman representam a cena de muitos filmes e de nenhum deles ao mesmo tempo. Ela se apoia em cacoetes de representação das personagens femininas nas sociedades afluentes, porém patriarcais, do pós-guerra. Como melhor definiu Rosalind Krauss, suas fotografias são simulacros sem original ${ }^{415}$. Os trabalhos são Stills sem título e também Stills de filmes sem título. As personagens não existem nem na vida, nem no cinema, são arquétipos do feminino. Soterradas nesses clichês, algumas dessas personagens desaparecem, sobretudo nas últimas fotografias da série (159-162).

Sherman começa a trabalhar muito cedo. Ela fez seus primeiros Film stills com 23 anos de idade. A sua geração é a primeira a assimilar, já na escola de artes, a produção das neovanguardas do pós-guerra. A série dos Stills é inspirada por artistas feministas da geração anterior, como Hannah Wilkie, Ewa Partum e Suzy Lake (94-97), que usavam o corpo como o suporte de sua prática artística. ${ }^{416}$

\footnotetext{
${ }^{412}$ Cf. KRAUSS, Rosalind. “Cindy Sherman: Untitled (1993)”. Em BURTON, Johana. (Org.) Cindy Sherman (October Files). Cambridge: MIT Press, 2006. p. 98; e SILVERMAN, Kaja. "How to face the gaze”. Em BURTON, Johana. (Org.) Cindy Sherman (October Files). Cambridge: MIT Press, 2006. p. 163.

${ }^{413} \mathrm{O}$ filme Imitation of life, de Sirk, foi uma referência fundamental na geração de Cindy Sherman. Artistas próximos a ela no começo da carreira, como David Salle e Sherrie Levine trataram o filme com uma de suas maiores influências. O filme é um melodrama racial, que trata de uma garota negra que esconde sua origem para evitar as barreiras do racismo. EKLUND, Douglas. The Pictures Generation 1974-1984. Nova York: Metropolitan Museum of Art, 2009. p. 214.

${ }^{414}$ SILVERMAN, Kaja "How to face the gaze". Em BURTON, Johana. (Org.) Cindy Sherman (October Files). Cambridge: MIT Press, 2006.

${ }^{415}$ KRAUSS, Rosalind. "Cindy Sherman: Untitled (1993)". Em BURTON, Johana. (Org.) Cindy Sherman (October Files). Cambridge: MIT Press, 2006. p. 98.

${ }^{416}$ RESPINI, Eva. "Will Cindy Sherman please stand up? Em Museum of Modern Art, 2012. p. 15. Cindy Sherman. Nova York: The
} 
A fotografia naquela produção conceitual não tem caráter de obra, mas de registro de práticas artísticas muitas vezes não passíveis de ser transformadas em objeto. O uso conceitual da fotografia é chamado por Jeff Wall de "introversão ou subjetivação da reportagem". ${ }^{417}$ Elas abrem mão do caráter de obra, supõem-se neutras, objetivas, desprovidas de interesse estético. Atuariam como relatos não artísticos de alguma atividade criativa. ${ }^{418}$.

Como Cindy Sherman lida com a simulação, aceita o caráter cênico das imagens. Por isso, seu trabalho se afasta do verismo da arte conceitual. As imagens são cênicas, muito elaboradas. A ambientação, a luz, as locações, a maquiagem, o figurino, tudo precisa ser convincente. Sherman afeta trejeitos, expressões e formas de encarar a câmera (155 -156). Não se trata do uso da foto como registro de uma ação performática ou somente da criação de personagens.

Sherman cria a cena, organiza-a como uma composição a ser contemplada.

As fotografias são feitas para serem mostrados em salas de exposição com as melhores condições, mas querem se assemelhar às fotografias de divulgação. Parte do sentido, é lidar com essas ambiguidades, mesmo que as imagens tenham autonomia e interesse individual. Cindy Sherman usa a forma dos stills de cinema como linguagem.

Tal emprego só é possível porque o meio da arte contemporânea, quando Cindy Sherman começa a trabalhar, já está plenamente constituído. Andy Warhol e Gerhard Richter viveram a transição das formas de inteligibilidade da obra de arte. A prática desses artistas estabelece uma nova relação com a imagem fotográfica e com os

\footnotetext{
417 WALL, Jeff. “Marks of Indifference”. Em Selected Essays and Interviews. Nova York: The Museum of Modern Art, 2007. p. 150.

${ }^{418}$ Idem, p. 150-155.
} 
signos modernos vindos dos meios de comunicação de massa. A imagem da arte se torna indistinta de códigos visuais produzidos em outros contextos.

Essa modificação permite novas formas de prática artística. Depois dos anos 1970, muitos artistas não criam objetos, nem imagens, mas elaboram formas de interferir em circuitos pré-existentes de comunicação ou de questionar o modo de funcionamento das instituições culturais.

Recentemente, museus, grandes exposições de arte não são instituições e eventos dedicadas apenas à conservação, exibição e pesquisa da produção estética. Também funcionam como uma espécie de "plataforma" (na falta de palavra melhor) para outras práticas. Elas podem ser desde a criação de áreas de lazer até o ativismo político. De qualquer modo, tais ações atendem às necessidades de um público de massa, que procura nas instituições culturais algo além da mera contemplação de um acervo. Tais obras e espaços, por mais militantes que pretendam ser, participam de um circuito de bens culturais e entretenimento da sociedade de consumo.

Andy Warhol e Gerhard Richter são pioneiros na consciência de que a produção artística, como todo o resto da vida social urbana, estava permeada pelas linguagens dos meios de comunicação de massa. Um e outro dão respostas muito diversas a essa situação. Coincidem no diagnóstico. As suas pinturas reconhecem que a lida com esses media até podem abrir novas formas de criação, mas em um mundo com possibilidades de transformação muito reduzida.

Os dois artistas têm uma relação melancólica e resignada com o século XX. Afinal, nenhuma das grandes promessas parece ter se realizado e as que tomaram corpo, na maior parte das vezes, converteram-se no seu contrário. Sobra à obra de arte expectativas modestas e belezas contingentes. 
BIBLIOGRAFIA 
ADORNO, Theodor: Minima Moralia: reflexões a partir da vida lesada. Rio de Janeiro, Beco do Azougue, 2008. (Tradução Gabriel Cohn).

ADORNO, Theodor: Teoria Estética. Lisboa, Edições 70 (Arte \& Comunicação), 2008. (Tradução Artur Morão).

ADORNO, Theodor: Três Estudos Sobre Hegel. São Paulo, Editora Unesp, 2007. (Tradução Ulisses Razzante Vaccari)

ADORNO, Theodor W. \& HORKHEIMER. Dialética do esclarecimento: fragmentos filosóficos. Trad. Guido Antônio de Almeida. 2. ed. Rio de Janeiro: Jorge Zahar Editor, 1986.

ADORNO, Theodor. "Crítica cultural e sociedade" em Prismas: crítica cultural $e$ sociedade. São Paulo: Ática, 1998.

ALBERRO, Alexander. STIMSON, Blake: Conceptual art: a critical anthology. Cambridge:Massachusetts Institute of Technology, 1999.

ALIAGA, Juan Vicente: “Conversation with Luc Tuymans” em SPECTOR, Nancy: Luc Tuymans. Londres, Phaidon Press, 2003.

ANGELL, Callie. Andy Warhol Screen Tests. The Films of Andy Warhol Catalogue Raisonné. 319 pp. New York: Harry N. Abrams Inc., 2006.

AQUIRRE, Peio e AZIMI, Negar: Vitamin P2: New perspectives in painting, London, Phaidon Press, 2011.

ARGAN, Giulio Carlo: "O valor crítico da "gravura de tradução"” em Imagem $e$ Persuasão: ensaios sobre o barroco. (Organização: Bruno Contardi/ tradução: Maurício Santana Dias). São Paulo, Companhia das Letras, 2004. 
BACON, Alex e FOSTER, Hal (editores): Richard Hamilton (October Files), Cambridge, MIT Press, 2010.

BARTHES, Roland: “That old thing, art” em TAYLOR, Paul (ed.): Post-Pop Art (New art criticism series). Cambridge: Massachusetts Institute of Technology, 2007 (2a. edição).

BARTHES, Roland: “A mensagem fotográfica” em O Óbvio e o Obtuso. Tradução Isabel Paschoal. Lisboa, Edições 70

BAUDELAIRE, Charles: Charles Baudelaire: Poesia e Prosa. (volume traduzido e organizado por Ivo Barroso). Rio de Janeiro: Editora Nova Aguilar, 1995.

BAUDELAIRE, Charles: “Salão de 1859”, Charles Baudelaire: Poesia e Prosa. Rio de Janeiro, Editora Nova Aguilar, 1995.

BAUDRILLARD, Jean: "Pop: arte de consumo" (publicado originalmente em 1970) em A Sociedade de Consumo. Lisboa, Edições 70, 2007.

BAUDRILLARD, Jean: Para uma crítica da economia política do signo. Tradução: Artur Mourão. Rio de Janeiro, Elfos, 1995.

BAZIN, André: "Ontologia da imagem fotográfica" em $O$ que é o cinema. (tradução: Hugo Mader). São Paulo, Cosac Naify, 2014.

BELTING, Hans: Art History After Modernism. (trad. Hans Belting, Mitch Cohen e Kenneth J. Northcott) Chicago: University Of Chicago Press, 2003.

BELTING, Hans: O fim da história da arte: uma revisão dez anos depois. São Paulo, Cosac Naify, 2006. 
BENJAMIN, Walter: "A Obra de arte na era de sua reprodutibilidade técnica" in Magia e técnica, arte e política: Ensaios sobre literatura e história da cultura - Obras escolhidas I. São Paulo: Brasiliense, 1994.

BENN MICHAELS, Walter: The Beauty of a Social Problem. Chicago, The University of Chicago Press, 2015

BENN MICHAELS, Walter: "Neoliberal Aesthetics" em nonsite.org, Issue \#1, 25 de janeiro de 2011 (em http://nonsite.org/article/neoliberal-aesthetics-fried-ranciere-andthe-form-of-the-photograph ), Atlanta, Emory College of Arts and Sciences.

BIESENBACH, Klaus: Douglas Gordon, Timeline. Nova York, Moma, 2012.

BLAZWICK, Iwana e GRAHAM, Janna: Atlas, the reader. Londres, Whitechapel Gallery, 2004.

BOCKRIS, Victor: Warhol: The Biography. Boston, Da Capo Press, 2003.

BOIS, Yve-Alain, BUCHLOH, Benjamin H.D., FOSTER, Hal e KRAUSS, Rosalind: Art since 1900. Modernism, antimodernism, postmodernism. Londres: Thames \& Hudson, 2004

BOURRIAUD, Nicolas: Pós-Produção: Como a arte reprograma o mundo contemporâneo. São Paulo, Martins Fontes, 2009.

BUCHLOH, Benjamin: “A Note on Gerhard Richter's "October 18, 1977". October, Vol. 48 (Spring, 1989), pp. 88-109. Cambridge, The MIT Press, 1989.

BUCHLOH, Benjamin: "From faktura to factography". October, Vol. 30, Autumn, The MIT Press, 1984. 
BUCHLOH, Benjamin: "Atlas, Warburg's paragon? The end of collage and photomontage in postwar Europe". In: SCHAFFNER, Ingrid; WINZEN, Mathias. Deep Storage: collecting, storing, and archiving in art. New York, Munich: Prestel-Verlag, 1998.

BUCHLOH, Benjamin: Neo-avantgarde and Culture Industry: essays on European and American Art from 1955 to 1975. Cambridge, MIT Press, 2000.

BUCHLOH, Benjamin: “Andy Warhol's one dimensional art” em MICHELSON, Anette (org.): Andy Warhol (October Files). Cambridge, MIT Press, 2001.

BUCHLOH, Benjamin H. D (editor).: Gerhard Richter(October Files). Cambridge, MIT Press, 2009.

BUCHLOH, Benjamin H. D.: “An interview with Gerhard Richter (2004) em BUCHLOH, Benjamin H. D (editor).: Gerhard Richter(October Files). Cambridge, MIT Press, 2009.

BUCHLOH, Benjamin: “Atlas de Gerhard Richter:o arquivo anômico. Arte \& Ensaios, Rio de Janeiro, n.19, p.194-209, 2009.

BUCHLOH, Benjamin: "Isa Genzken: The fragment as model” em LEE, Lisa (ed.): Isa Genzken (October Files).. Cambridge, MIT Press, 2015.

BUCHLOH, Benjamin: "Figures of Authority, Ciphers of Regression. Notes on the return of the return of representation in the European painting" em Formalism and Historicity: Models and Methods in Twentieth-Century Art, Cambridge, MA: MIT Press, 2015. (p. $115-171)$

BURTON, Johana (org.): Cindy Sherman (October Files). Cambridge, MIT Press, 2006. 
BUTIN, Hubertus: "Unknow photographic works by Gerhard Richter” em GRONERT, Stefan: Gerhard Richter. Portraits. Alemanha, Hatje Cantz, 2006. (tradução do alemão para o inglês: Melissa Thorston Hause).

CAMERON, Dan e CHRISTOV-BAKARGIEV, Carolyn: William Kentridge. Londres, Phaidon Press, 1999.

CARTIER-BRESSON, H. O instante decisivo. (Tradução de Samuel Titan Jr.) Em Revista Zum n. 1, São Paulo, Instituto Moreira Salles, outubro 2011.

CHENIEUX-GENDRON, Jacqueline. O surrealismo. Trad. Mario Laranjeira. São Paulo: Martins Fontes, 1992..

CHEVRIER, Jean-François: "Between the fine arts and the media (the German Example: Gerhard Richter" (1992) em BLAZWICK, Iwana e GRAHAM, Janna: Atlas, the reader. Londres, Whitechapel Gallery, 2004.

CHEVRIER, Jean-François: "Advetures of the Picture form in the history of photography" em FOGLE, Douglas: The last Picture show: Artists using photography, 1960-1982. Minneapolis, Walker Art Center, 2003.

CLARK, T.J.: Picasso and truth: from cubism to Guernica. Princeton, Princeton University Press, 2013.

CLARK, T.J.: "Grey Panic” na London Review of Books Vol. 33 No. 22 (pages 3-7), do dia 17 de Novembro de 2011. http://www.lrb.co.uk/v33/n22/tj-clark/grey-panic

COELHO, Frederico e DIEGUES, Isabel (editores): Pintura Brasileira Século XXI. Rio de Janeiro, Cobogó, 2011.

COKE, Van Deren. The Painter and the Photographer, From Delacroix to Warhol. Albuquerque, New Mexico: University of New Mexico Press, 1964. 
COOKE, Lynne: "From the Independent Group: British and American Pop Art, a Palimpcestous Legacy" [1990], in S. H. Madoff (org.). Pop Art: A Critical History. Berkeley: University of California Press, 1997.

COOKE, Lynne: “Gerhard Richter Atlas, 1995” em BLAZWICK, Iwana e GRAHAM, Janna: Atlas, the reader. Londres, Whitechapel Gallery, 2004.

COPLANS, John: "The new paintings of common objects em MADOFF, S.H.(editor): Pop Art: A critical history. Berkley, University of California Press, 1997.

COSTELlO, Diarmuid e IVERSEN,Margaret (ed.): Photography after Conceptual Art. Oxford, Blackwell Publishing, 2007.

CRARY, Jonathan: Técnicas do observador: visão e modernidade no século XIX. Rio de Janeiro, Contraponto, 2012.

CRAWFORD, Karin L.: “Gender and Terror in Gerhard Richter's October 18, 1977 and Don DeLillo's "Baader-Meinhof". New German Critique, No. 107, Dada and Photomontage across Borders (Summer,2009), pp. 207-230. Durham, Duke University Press, 2009.

CRESAP, Kelly M.: Pop Trickster Fool. Urbana e Chicago, University of Illinois Press, 2004.

CRIMP, Douglas “Spacious” em October 132 [“Andy Warhol: A Special Issue”; editado por Benjamin H. D. Buchloh]. Cambridge, MIT Press, 2010.

CRIMP, Douglas: Our Kind of Movie: The Films of Andy Warhol. Cambridge, The MIT Press, 2012.

CRIQUI, Jean-Pierre (ed.): On \& By Christian Marclay. Londres, Whitechapel Gallery, 2014. 
CROW, Thomas: The Simple Life: Pastoralism and the Persistence of Genre in Recent Art. October, Vol. 63 (Winter, 1993), pp. 41-67. Cambridge, The MIT Press, 1993.

CROW, Thomas: Saturday night disasters: trace and reference in early Warhol em MICHELSON, Anette (org.): Andy Warhol (Ocober Files). Cambridge, MIT Press, 2001.

CROW, Thomas: Modern Art in the Common Culture, New Haven, Yale University Press, 1996.

CROW, Thomas: The Rise of The Sixties, Londres, Lawrence and King, 1996.

CROW, Thomas: The long march of pop: art, music and design, 1930 - 1995, New Haven, Yale University Press, 2014.

CURLEY, John J.: A Conspiracy of Images. New Haven e Londres, Yale University Press, 2013.

DALTON, David: "Matinee Idols" em GOLDSMITH, Kenneth (org.): Andy Warhol Giant Size. Londres e Nova York, 2006. DANTO, Arthur C. : Andy Warhol. São Paulo, Cosac Naify, 2012.

DAMISCH, Hubert: "Notes for a Phenomenology of the Photographic Image". October, Vol. 5, Photography (Summer, 1978), pp. 70-72. Cambridge, MIT Press, 1978.

DANCHEV, Alex: "The Artist and the Terrorist, or The Paintable and the Unpaintable: Gerhard Richter and the Baader-Meinhof Group" Source: Alternatives: Global, Local, Political, Vol. 35, No. 2 (Apr.-June 2010), pp. 93-112. Thousand Oaks, Califórnia, Sage Publications, Inc, 2010.

DANTO, Arthur C.: "The Art World Revisited: Comedies of Similarity" em Beyond the Brillo Box: The visual arts in post-Historical Perspective. Nova York, Farrar, Strauss \& Giroux, 1992 
DANTO, Arthur C., A transfiguração do lugar comum. São Paulo, Cosac Naify, 2006.

DEBORD, Guy: A Sociedade do Espetáculo. Tradução Estela dos Santos Abreu. Rio de Janeiro, Contraponto, 1997.

DIDI-HUBERMAN, Georges: A imagem sobrevivente. Tradução: Vera Ribeiro. Rio de Janeiro, Contraponto, 2013.

DIDI-HUBERMAN, Georges: Confronting Images. Filadélfia, The Pennsylvania State University, 2005.

DIDI-HUBERMAN, Georges: Images in spite of all. Chicago, University of Chicago Press, 2008.

DIENST, Rolf Gunther: "Intervista” em HONISCH, Dieter (comissário): Catálogo do Pavilhão Alemão da 36 Bienal de Veneza. Veneza, 1972.

DOIG, Peter: Charley's Space, Nimes, Musee d'art Contemporain, 2003.

DUBOIS, Philippe: $O$ ato fotográfico e outros ensaios. Tradução: Marina Appenzeller, Campinas, Papirus, 1993.

DOYLE, Jennifer, FLATLEY, Jonathan e MUÑOZ, José Esteban (eds)., Pop Out: Queer Warhol. Durham, Chappel Hill (NC): Duke University Press, 1996.

EICHLER, Dominic, HEISER, Joerg e PRZYWARA, Andrzei: Wilhelm Sasnal. Londres, Phaidon Press, 2011.

EKLUND, Douglas: The Pictures Generation, 1974-1984. Nova York, Metropolitan Museum of Art, 2009.

ELGER, Dietmar e OBRIST, Hans Ulrich: Gerhard Richter - Text: Writings, Interviews and Letters. Londres, Thames And Hudson, 2009. 
ELGER, Dietmar: Gerhard Richter: A Life in Painting. Chicago, University Of Chicago Press, 2010.

ELIAS, Norbert: "Lúcifer sobre as ruínas do mundo" e "Terrorismo na República Federal da Alemanha - expressão de um conflito social entre gerações" em ELIAS, Norbert: Alemães. Rio de Janeiro, Jorge Zahar Editor, 1987. (Tradução: Álvaro Cabral).

ENTLER, Ronaldo. A fotografia e as representações do tempo. Revista Galáxia, São Paulo, n. 14, p. 29-46, dez. 2007.

ENZENSBERGER, Hans Magnus: Critical essays. Nova York, The Continuum Publishing Company, 1982.

ENZENSBERGER, Hans Magnus: Com Raiva e Paciência: Ensaios sobre literatura, política e colonialismo. Rio de Janeiro, Paz e Terra, 1985. (Traduçao: Lya Luft).

ENWEZOR, Onkwui: "Die bedingungen der spektralität und des sehens in den fotografien von Thomas Ruff (The conditions of spectrality and spectatorship in Thomas Ruff photographs) " em Thomas Ruff: works 1979 - 2011. Munique, Schirmer/Mosel, 2012

ESPADA, Heloísa e MAMMÌ, Lorenzo (org.): Lugar Nenhum, Rio de Janeiro, Instituto Moreira Salles, 2013.

FABRIS, Annateresa: O Desafio do Olhar, volume I, São Paulo, Wmf Martins Fontes, 2013

FABRIS, Annateresa: A fotografia e a crise da modernidade. Belo Horizonte, C/ Arte, 2015.

FERGUSON, Russel (org.) Douglas Gordon. Los Angeles, MOCA, 2001. 
FINCH, Christopher: Pop art: object and image. Londres, Studio Vista, 1968.

FLATLEY, Jonathan: "Like: Collecting and Collectivity" em October 132 [“Andy Warhol: A Special Issue"; editado por Benjamin H. D. Buchloh]. Cambridge, MIT Press, 2010.

FOGLE, Douglas: The last Picture show: Artists using photography, 1960-1982. Minneapolis, Walker Art Center, 2003.

FOSTER, Hal: Compulsive Beauty, Cambridge, MIT Press, 1993.

FOSTER, Hal: The First Pop Age, Princeton, Princeton University Press, 2012.

FOSTER, Hal: O retorno do real. Tradução: Célia Euvaldo. São Paulo, Cosac Naify, 2014.

FOSTER, Hal: “Test subjects” em October 132 [“Andy Warhol: A Special Issue”; editado por Benjamin H. D. Buchloh]. Cambridge, MIT Press, 2010.

FRIED, Michael: "From New York Letter" (1962) em MADOFF, S.H. (editor): Pop Art: A critical history. Berkeley, University of California Press, 1997.

FRIED, Michael: “Orientation in painting” em Another light: Jacques-Louis David to Thomas Demand. New Haven, Yale University Press, 2014.

FRIED, Michael: Absorption and theatricality. Chicago, University of Chicago Press, 1988 (primeira edição de 1980). 2014.

FRIED, Michael: Why photography matters as art as never before. New Haven e Londres, Yale University Press, 2008. 
FRIEDEL, Helmut: “Atlas: photographs, collages and sketches, 1962 - 2006” em RICHTER, Gerhard: Atlas. Colônia, Verlag der Buchhandlung Walter König e Nova York, DAP, 2006. (segunda edição, 2011).

GANDY, Matthew: "Contradictory Modernities: Conceptions of Nature in the Art of Joseph Beuys and Gerhard Richter". Annals of the Association of American Geographers, Vol. 87, No. 4 (Dec., 1997), pp. 636-659. Oxford, Taylor \& Francis, Ltd. on behalf of the Association of American Geographers, 1997.

GIDAL, Peter: Blow Job. Londres, Afterall Books, 2008

GODFREY, Mark e SEROTA, Nicholas: Gerhard Richter|Panorama. Londres, Tate, 2011.

GOLDSMITH, Kenneth (org.): Andy Warhol Giant Size. Londres e Nova York, 2006.

GRAW, Isabelle: "When Life Goes to Work: Andy Warhol” em October 132 ["Andy Warhol: A Special Issue"; editado por Benjamin H. D. Buchloh]. Cambridge, MIT Press, 2010.

GREENBERG, Clement: "Vanguarda e kitsch" em Arte e cultura. São Paulo, Editora Ática, 1996.

GRUNDBERG, Andy: The representation of abstraction/ The abstraction of represetation" em Crisis of the real. Nova York, Aperture Foundation.

GRUNDBERG, Andy: "Magnum's postwar paradox" em Crisis of the real. Nova York, Aperture Foundation.

GUILBAUT, Serge. How New York Stole the Idea of Modem Art: Abstract Expressionism, Freedom, and the Cold War. Chicago: University of Chicago Press, 1993. 
HABERMAS, Jürgen: Mudança estrutural na esfera pública: investigações quanto a uma categoria da sociedade burguesa. (tradução: Flávio Kothe). Rio de Janeiro, Tempo Brasileiro, 1984. (p. 56).

HAIDU, Rachel: “Arrogant Texts: Gerhard Richter's Family Pictures (2007)” em BUCHLOH, Benjamin H. D (editor).: Gerhard Richter(October Files). Cambridge, MIT Press, 2009.

HAMILTON, Richard: "Letter to Peter and Alison Smithson (1957)" em FRANCIS, Mark e FOSTER, Hal (ed.): Pop (Themes and movements). Londres, Phaidon Press, 2005.

HAMRAH, A. S.: “The Beckett/Bushmiller Letters" em Hermenaut No. 15, 1999. Consultado em http://theamericanreader.com/the-beckettbushmiller-letters/ (10/03 2016)

HAWKER, Rosemary: “The Idiom in Photography As the Truth in Painting”. The South Atlantic Quarterly, Volume 101, Number 3, Summer 2002, pp. 541-554. Durham, Duke HAWKER, Rosemary: “Idiom Post-medium: Richter Painting Photography”. Artigo em Oxford Art Journal, Vol. 32, No. 2 (2009), pp. 263, 265-280. Oxford, Oxford University Press University Press, 2002.

HELMS, Dietrich: “Su Gerhard Richter” em HONISCH, Dieter (comissário): Catálogo do Pavilhão Alemão da 36a Bienal de Veneza. Veneza, 1972.

HOBSBAWM, Eric: Era dos Extremos: O breve século XX (1914 - 1991). Tradução: Marcos Santarita. São Paulo, Companhia das Letras, 1995.

HOME, Stewart. Assalto à cultura: utopia subversão guerrilha na (anti) arte do século XX. Tradução Cris Siqueira. São Paulo: Conrad, 1999. 
HONISCH, Dieter: “A proposito di Gerhard Richter” em Catálogo do Pavilhão Alemão da 36ª Bienal de Veneza. Veneza, 1972.

HONNEF, Klaus: "Schwierigkeiten beim beschreben der realität: Richters Malerei zwischen kunst und wirklichkeit” em RICHTER, Gerhard: Gerhard Richter 1969 (katalog 3/69). Aachen, Zentrum für aktuelle kunst, 1969.

HONNEF, Klaus: "La pittura di Richter: tra arte e realitá" em HONISCH, Dieter (comissário): Catálogo do Pavilhão Alemão da 36 a Bienal de Veneza. Veneza, 1972.

HONNEF, Klaus: Arte Contemporaneo. Colônia, Taschen, 1993.

HUGHES, Robert: American Visions. Nova York, Alfred Knopf Inc, 1997

HUYSSEN, Andréas - “A política Cultural da Pop” em Memórias do Modernismo, Rio de Janeiro, Editora da UFRJ 1996

JAMESON, Fredric: Pós-Modernismo: a lógica cultural do capitalismo tardio. Tradução: Maria Elisa Cevasco e Iná Camargo Costa. São Paulo, Ática, 2007.

JANIS, Sidney: "On the theme of exhibitions" em MADOFF, S.H.(editor): Pop Art: A critical history. Berkley, University of California Press, 1997.

JAPPE, Anselm. Guy Debord. Tradução Iraci D. Poleti. Petrópolis: Vozes, 1999.

JASKOT, Paul B.: “Gerhard Richter and Adolf Eichmann”, Oxford Art Journal, Vol. 28, No. 3 (2005), pp. 459-478. Oxford, Oxford University Press, 2005.

JOSEPH, Branden W.: “1962” em October 132 [“Andy Warhol: A Special Issue”; editado por Benjamin H. D. Buchloh]. Cambridge, MIT Press, 2010.

JUDT, Tony: Postwar: A History of Europe since 1945. Nova York, Penguin Books, 2006. 
KANTOR, Jordan: "The Tuymans effect”, Artforum vol 43, no. 3 (novembro de 2004). Reeditado em MYERS, Terry E. (editor): Painting, Londres e Cambridge, Whitechapel Gallery e MIT Press, 2011.

KARP, Ivan: “Andy Starts to paint” em GOLDSMITH, Kenneth (org.): Andy Warhol Giant Size. Londres e Nova York, 2006

KENTRIDGE, William: The refusal of time. Paris, Editions Xavier Barral, 2012.

KERN, Daniela: "John Ruskin, Arte e Fotografia: aceitação e resistência” em Anais do XXX Colóquio do Comitê Brasileiro de História da Arte, Rio de Janeiro, CBHA, 2010.

KOCH, Gertrud: “The Richter-Scale of Blur” em BUCHLOH, Benjamin H. D (editor):: Gerhard Richter (October Files). Cambridge, MIT Press, 2009.

KOCH, Stephen: Stargazer: The life, world and films of Andy Warhol (reedição). Nova York, Marion Boyars, 1991.

KOERNER, Joseph Leo: Caspar David Friedrich and the Subject of Landscape (segunda edição). Londres, Reaktion Books, 2009 (primeira edição em 1990).

KOERNER, Joseph Leo: “Monstrance, 2009” em RUYFFELAERE, Peter: On and By Luc Tuymans. Boston, MIT Press; Londres, Whitechappel Gallery, 2013.

KOSELLECK, Reinhart: Futuro passado: contribuição à semântica dos tempos históricos. Rio de Janeiro, Contraponto/Puc Rio, 2006.

KOSINSKI, Dorothy (ed.): The Artist and the câmera. New Haven, Yale University Press e Dallas, Dallas Museum of Art, 2000.

KRACAUER, Siegfried: “A fotografia” em Ornamento da Massa (tradução Carlos Eduardo Jordão Machado e Marlene Holzhausen). São Paulo, Cosac Naify, 2009. 
KRAUSS, Rosalind: “Cindy Sherman: Untitled (1993)” em BURTON, Johana (org.): Cindy Sherman (October Files). Cambridge, MIT Press, 2006.

KRAUSS, Rosalind: O Fotográfico. Barcelona, Editorial Gustavo Gili, 2002.

KRAUSS, Rosalind: Perpetual Inventory, Boston, MIT Press, 2010.

KRAUSS, Rosalind: The Optical Unconscious, Boston, MIT Press, 1993.

KRAUSS, Rosalind: Under the Blue Cup, Boston, MIT Press, 2011.

KUREISHI, Hanif e SAVAGE, Jon (org.). The Faber Book of Pop. Londres: Faber \& Faber, 1995.

LAJER-BURCHARTH, Ewa: "Warhol's Subject? A Response to Douglas Crimp" em October 132 [“Andy Warhol: A Special Issue”; editado por Benjamin H. D. Buchloh]. Cambridge, MIT Press, 2010.

LAXTON, Susan: “As Photography: Mechanicity, Contingency, and OtherDetermination in Gerhard Richter's Overpainted Snapshots. Critical Inquiry”, Vol. 38, No. 4, Agency and Automatism: Photography as Art Since the Sixties, edited by Diarmud Costello, Margaret Iversen, and Joel Snyder (Summer 2012), pp. 776-795. Chicago, The University of Chicago Press, 2012.

LANGSNER, Jules: "From Los Angeles Letter". MADOFF, Steve Henry: Pop Art: critical history. Berkeley, University of Californa Press, 1997 (p.33 - 34). Originalmente publicado na revista Art International, em setembro de 1962.

LEE, Lisa (ed.): Isa Genzken (October Files). Cambridge, MIT Press, 2015.

LEWALLEN, Constance M.: A Rose has no teeth, Bruce Nauman in the sixties. Berkeley, University of California Press, 2007. 
LIPPARD, Lucy: A Arte Pop. Lisboa, Editorial Verbo, 1973.

LOOCK, Ulrich: "On layers of sign-relations, in th light of mechanically reproduced pictures from tem years of exhibitions" em SPECTOR, Nancy: Luc Tuymans. Londres, Phaidon Press, 2003.

LORD, Catherine: "Wonder Waif Meets Super Neuter" em October 132 [“Andy Warhol: A Special Issue"; editado por Benjamin H. D. Buchloh]. Cambridge, MIT Press, 2010.

LOTZ, Christian: "Distant Presence. Representation, Painting and Photography in Gerhard Richter's Reader," Symposium. Canadian Journal for Continental Philosophy, $1 / 2012$.

LOTZ, Christian: The Art of Gerhard Richter. Hermeneutics, Images, Meaning, Londres, Bloomsbury Press, 2015.

MADOFF, S.H.(editor): Pop Art: A critical history. Berkley, University of California Press, 1997.

MAMMI, Lorenzo: O que resta. São Paulo, Companhia das Letras, 2012.

MARCLAY, Christian: The Clock, Londres, White Cube, 2010.

MAZOWER, Mark. Dark Continent: Europe's Tentieth Century. Londres: Penguin Group, 1998.

McSHINE, Kynaston (org.): Andy Warhol: A retrospective. Nova York, The Museum of Modern Art, 1989.

MEHRING, Christine: “Richter's Willkür” Art Journal, Vol. 71, No. 4 (Winter 2012), pp. 20-35. College Art Association, 2012. 
MESQUITA, Tiago: "Ana Elisa Egreja" em EGREJA, A.E.: Ana Eleisa Egreja. Rio de Janeiro, Cobogó, 2013.

MESQUITA, Tiago. Resistência da matéria Rodrigo Andrade. 1. ed. Rio De Janeiro: Cobogó, 2014.

MEINHARDT, Johannes: "Illusionism in painting and the punctum of photograph" (trad. Russel Stockman) em BUCHLOH, Benjamin H. D (editor).: Gerhard Richter (October Files). Cambridge, MIT Press, 2009.

MICHELSON, Anette (org.): Andy Warhol (Ocober Files). Cambridge, MIT Press, 2001.

MILLER, Barbara L.: "Gingerbread Houses: Art, food and the postwar architecture of the domestic places" em HORWITZ, Jamie e SINGLEY, Paulette (orgs.): Eating Architecture. Cambridge, MIT Press, 2006.

MORAMARCO, Fred: "Kindred Muses: American Poetry and Painting” em The Journal of Aesthetic Education, Vol. 11, No. 4 (Oct., 1977), pp. 67-78. Champaign, University of Illinois Press.

MORRIS, Robert: "From a chomskian couch" Have I Reasons: Work and Writings. Duke University Press Books, 2008.

MORRIS, Robert: "Jasper Johns: the first decade" Have I Reasons: Work and Writings. Duke University Press Books, 2008.

MULRONEY, Lucy: “Editing Andy Warhol” em Grey Room 46 (Winter 2012): 46-71. Cambridge, MIT Press.

MULRONEY, Lucy: Reading Andy Warhol: Author Illustrator Publisher. Berlim, Hatje Cantz, 2014. 
MULRONEY, Lucy: "Rereading the History of Photography" Photography \& Culture volume 2, no. 2., Julho de 2009. Oxford, Berg Publishers.: pg. 173-184.

NAUMAN, Bruce: Please Pay Attention Please: Bruce Nauman's Words. Cabridge, MIT Press, 2003.

NEWGARDEN, Mark e KARASIK, Paul: "How to Read Nancy" em RAW Magazine v. 1 \#7 in 1986 (pp. $98-105)$.

NEWHALL, Beaumont: The History of Photography: From 1839 to the present. New York: Museum of Modern Art, 1937.

NIELSEN, Kristian Hvidtfelt: "Nanotech, Blur and Tragedy in Recent Artworks by Gerhard Richter” em Leonardo, Vol. 41, No. 5 (2008), pp. 484-492, 452. Cambridge, MIT Press.

OBRIST, Hans Ulrich: "Gerhard Richter" em Entrevistas:volume 1. Rio de Janeiro, Cobogó; Belo Horizonte, Inhotim, 2009

O'DOHERTY, Brian: “Art: Avant-garde revolt (1962)” em MADOFF, S.H. (editor): Pop Art: A critical history. Berkeley, University of California Press, 1997.

OHFF, Heinz: "Su Gerhard Richter” em HONISCH, Dieter (comissário): Catálogo do Pavilhão Alemão da 36ª Bienal de Veneza. Veneza, 1972.

OSBORNE, Peter: "Painting Negation: Gerhard Richter's Negatives". October, Vol. 62 (Autumn, 1992), pp. 102-113. Cambridge, The MIT Press, 1992.

OSBORNE, Peter: “Abstract images: image, sign and aestheticin Gerhard Richter's paintin" em BUCHLOH, Benjamin H. D (editor).: Gerhard Richter (October Files). Cambridge, MIT Press, 2009. 
PANOFSKY, Erwin: Significado das Artes Visuais. São Paulo, Editora Perspectiva, 2001. ( $3^{\mathrm{a}}$. Edição)

PASCALE, Mark: “9 Objects (9 Objekte), 1968 by Gerhard Richter”.Art Institute of Chicago Museum Studies, Vol. 25, No. 1, Modern and Contemporary Art: The Lannan Collection at The Art Institute of Chicago (1999), pp. 36-37+102. Chicago, The Art Institute of Chicago, 1999.

PAUTZ, Michelle: “The Decline in Average Weekly Cinema Attendance”, Issues in Political Economy, 2002, Vol. 11. Consultado em http://org.elon.edu/ipe/pautz2.pdf $(10 / 01 / 2016)$.

PELZER, Brigit: "The Tragic Desire” em BUCHLOH, Benjamin H. D (editor).: Gerhard Richter (October Files). Cambridge, MIT Press, 2009.

PERL, Jed: New art city: Nova York, capital da arte. São Paulo: Companhia das letras, 2008 .

PERLOFF, Marjorie: The Poetics of Indeterminacy: Rimbaud to Cage. Evanston, Northwestern University Press, 1999

PEVSNER, Nikolaus: Academias de arte. (tradução: Vera Maria Pereira). São Paulo, Companhia das Letras, 2005

PLAGENS, Peter: Bruce Nauman, the true artist. New York, Phaidon Press, 2014.

RATTCLIFFE, Carter: Andy Warhol. Nova Yok, Abeville Press, 1983.

REICHARDT, Jason "Pop Art and after" [1963], in S. H. Madoff (org.). Pop Art: A Critical History. Berkeley: University of California Press, 1997. 
RICHTER, Gerhard: Gerhard Richten: Arbeiten 1962 - 1971. Dusseldorf, Kunsteverein für die Rheinland und Westfalen, 1971.

RICHTER, Gerhard: Atlas. Colônia, Walter König e Helmut Friedel (Nova York, dap), 2006.

RICHTER, Gerhard e BUCHLOH, Benjamin: Gerhard Richter Bikernau Paintings. Colonia, Verlag der Buchhandlung Walther König, 2016.

RICKEY, George: Construtivismo: origem e evolução. São Paulo, Cosac e Naify, 2002.

ROBERTS, John: Photography after the Photograph: Event, Archive, and the NonSymbolic, Oxford Art Journal, Vol. 32, No. 2 (2009). Oxford, Oxford University Press, 2009.

ROSE, Barbara: "Dada, then and now" em MADOFF, S.H.(editor): Pop Art: A critical history. Berkley, University of California Press, 1997.

ROSE, Barbara: "Pop Art at the Guggenheim" em MADOFF, Steve Henry: Pop Art: critical history. Berkeley, University of Californa Press, 1997.

ROSENBLUM, Robert: Modern Painting And The Northern Romantic Tradition: Friedrich To Rothko. Nova York, Harper Collins (Icon Editions), 1977.

ROSENBLUM, Robert: "Warhol as art history" em McSHINE, Kynaston (org.): Andy Warhol: A retrospective. Nova York, The Museum of Modern Art, 1989.

ROSENTHAL, Mark: William Kentridge, Five Themes. New Haven, Yale University Press, 2009.

RUGOFF, Ralph: The Painting of Modern Life, Londres, Hayward Press 2008. 
SALTZ, Jerry: "The Richter Resolution (2005)" republicado em MYERS, Terry R. (editor): Painting (Whitechapel documents of contemporary art), Londres e Cambridge, Whitechapel Gallery e MIT Press, 2011.

SALVESEN, Britt: See The Light: Photography, Perception, Cognition. Nova York: Prestel, 2013.

SAMAIN, Etienne (org.): Como Pensam as Imagens. Campinas, Editora da Unicamp, 2012.

SAVAGE, Jon "The Simple Things You See Are All Complicated”, in KUREISHI, Hanif e SAVAGE, Jon (org.). The Faber Book of Pop. Londres: Faber \& Faber, 1995.

SCHARF, Aaron: Art and photography. Penguin Books, 1978 (reimpressão, $1^{\mathrm{a}}$ edição de 1968).

SCHAPIRO, Meyer: Impressionismo: reflexões e percepções. Tradução: Ana Luiza Dantas Borges. São Paulo, Cosac \& Naify, 2002.

SCHWABSKY, Barry: Vitamin P: New perspectives in painting, Londres, Phaidon Press, 2004.

SEBALD, W.G.: Guerra Aérea e Literatura. São Paulo, Companhia das Letras, 2011. (tradução: Carlos Abbenseth e Frederico Figueiredo).

SEKULA, Allan: "On the invetion of photographic meaning” em GOLDBERG, Vicki: Photography in print. Nova York, Simon and Schuster, 1981.

SILVEIRA, Cristiane: "O mundo e os mundos da arte de Arthur C. Danto: uma teoria filosófica em dois tempos” em Revista ARS (São Paulo) vol.12 no.23 São Paulo Jan./June 2014. 
SILVERMAN, Kaja: "How to face the gaze" em BURTON, Johana (org.): Cindy Sherman (October Files). Cambridge, MIT Press, 2006.

SILVERMAN, Kaja: Flesh of My Flesh. Stanford, California. Stanford University Press, 2009.

SILVERMAN, Kaja: The miracle of analogy, or, The history of photography. Stanford University Press, Stanford, California, 2015.

SMYTHE, Luke: "Pixel: Painting in an Era of Light-Based Images" em Art Journal, Vol. 71, No. 4 (Winter 2012), pp. 104-118.

SONTAG, Susan: "Notas sobre Camp". Em Contra a interpretação. Porto Alegre: L\&PM, 1987.

SONTAG, Susan: Sobre Fotografia. São Paulo, Companhia das Letras 2004.

SONTAG, Susan: Diante da Dor dos Outros. Tradução: Rubens Figueiredo. São Paulo, companhia das Letras, 2003.

SPECTOR, Nancy: Luc Tuymans. Londres, Phaidon Press, 2003.

STALLABRASS, Julian: 'Gerhard Richter. Pintura y medios de comunicación”' Kalías (Valencia), no. 8, pp. 102-108, 1992.

STEINBERG, Leo: “A arte contemporânea e a situação de seu público” Outros Critérios. São Paulo, Cosac Naify, 2008.

STEINBERG, Leo: “Jasper Johns: Os sete primeiros anos de sua arte” Outros Critérios. São Paulo, Cosac Naify, 2008.

STORR, Robert: Gerhard Richter: October 18, 1977. Nova York, The Museum of Modern Art, 2000. 
STORR, Robert: Gerhard Richter: Forty years of painting. Nova York, The Museum of Modern Art, 2002.

SYLVESTER, David: "Warhol” in Sobre arte moderna. São Paulo: Cosac Naify 2006.

TASSINARI, Alberto: O Espaço Moderno. São Paulo: Cosac \& Naify Edições 2001.

TAYLOR, Paul (ed.): Post-Pop Art (New art criticism series). Cambridge: Massachusetts Institute of Technology, 2007 (2a. edição).

TONE, Lilian e LEONZINI, Nessia: Circuito Fechado: Filmes e vídeos de Bruce Nauman (1967 - 2001). Rio de Janeiro, Centro Cultural Banco do Brasil, 2005.

TONE, Lilian: William Kentridge: fortuna. Instituto Moreira Salles, 2012.

USSELMANN, Rainer: “18. Oktober 1977: Gerhard Richter's Work of Mourning and Its New Audience", Art Journal, Vol. 61, No. 1 (Spring, 2002), pp. 4-25. College Art Association, 2002.

VAGUE, Tom: Televisionários: a História da Facção Exército Vermelho, Mais Conhecida (por Engano) Como Grupo Baader-Meinhoff. São Paulo, Conrad Livros. 2001.

VALENTIN, Heike van den: ZERO. Curitiba, Museu Oscar Niemeyer, Porto Alegre, Fundação Iberê Camargo, São Paulo, Pinacoteca do Estado de São Paulo, 2013.

VARNEDOE, Kirk: "Introduction: A sense of life" em Jasper Johns: A retrospective. Nova York, The Museum of Modern Art, 1996.

WALL, Jeff: Selected Essays and Interviews. Nova York, The Museum of Modern Art, 2007.

WARBURG, Aby: A renovação da antiguidade pagã. Rio de Janeiro, Contraponto, 2013. 
WARHOL, Andy e HACKETT, Pat: Popismo: os anos 60 segundo Warhol. Tradução José Rubens Siqueira, Rio de Janeiro, Editora Cobogó, 2013.

WARHOL, Andy: A filosofia de Andy Warhol. Rio de Janeiro: Editora Cobogó 2008.

WEINGART, Brigitte: “That Screen Magnetism”: Warhol's Glamour” em October 132 [“Andy Warhol: A Special Issue”; editado por Benjamin H. D. Buchloh]. Cambridge, MIT Press, 2010.

WILLIAMS, Raymond: Televisão: tecnologia e forma social. São Paulo, Boitempo; Belo Horizonte, Puc Minas, 2016.

WILliAMS, Raymond: Política do Modernismo. São Paulo, Editora Unesp, 2011. (tradução: André Glaser)

WOLF, Reva: Andy Warhol: Poetry and Gossip in the 1960s. Chicago: University of Chicago, 1997.

WOOD, Lucas: "Snapshots of the Impossible: The Image as Critique”. Source: Journal of Modern Literature, Vol. 33, No. 1 (Fall 2009), pp. 159-163. Indiana University Press, 2009.

WOOD, Paul: "Truth and Beauty: The Ruined Abstraction of Gerhard Richter" em ROBERTS, John (ed.): Art Has No History! The Making and Unmaking of Modern Art. Londres, Verso Books, 1994.

YAU, John: "Luc Tuymans" em Art on Paper, Vol. 8, No. 1, Seventh Anniversary Issue (September-October 2003), pp. 44-47.

ZWEITE, Armin: “Gerhard Richter's álbum of photographs, collages and sketches” em BLAZWICK, Iwana e GRAHAM, Janna: Atlas, the reader. Londres, Whitechapel Gallery, 2004. 
CADERNO DE IMAGENS 


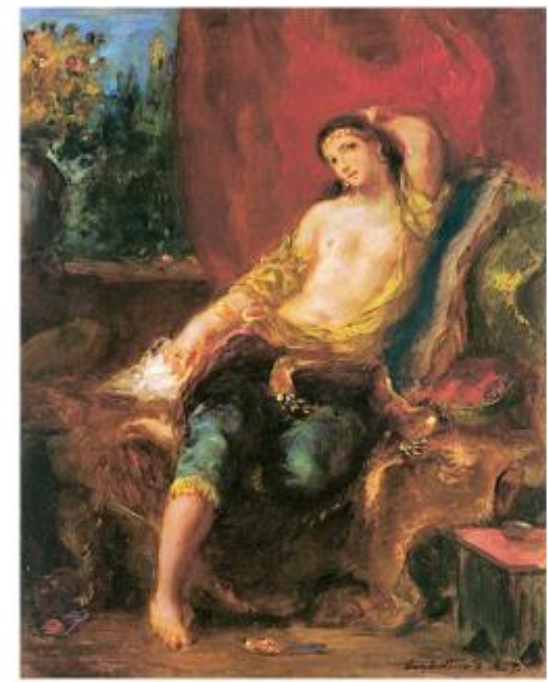

Eugéne Delacroix (1798-1863): Odalisca, 1857

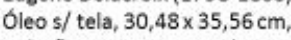

Coleção Stavros S. Niarchos, Atenas.

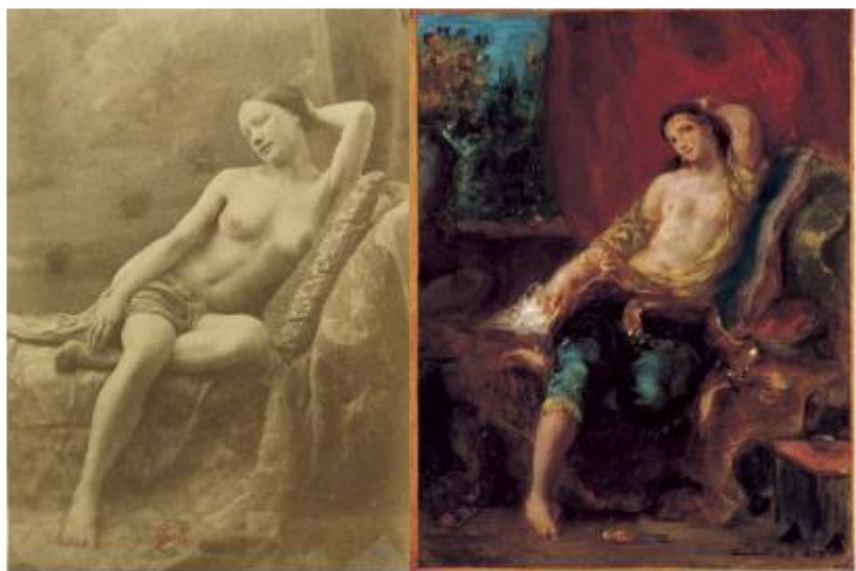

Fotógrafo desconhecido (atribuido a Eugene Durieu): Nu sentado, 1865, Biblioteca Nacional, Paris

Eugéne Delacroix (1798-1863): Odalisca, 1857, óleo s/ tela, 30,48 x 35,56 cm, coleção Stavros S. Niarchos, Atenas. 


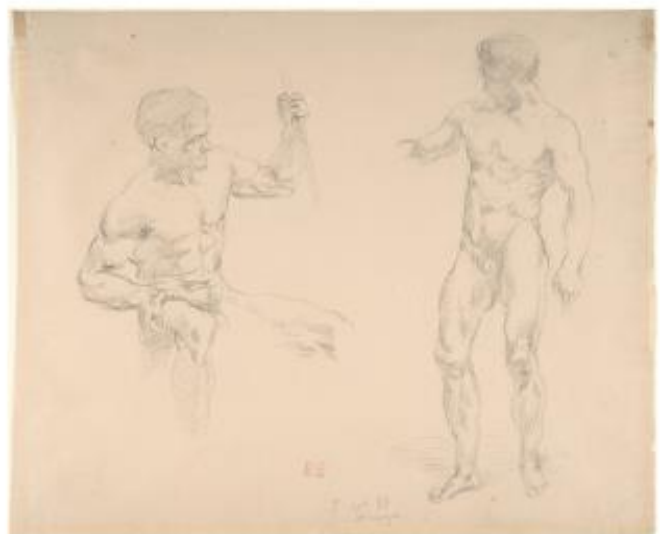

Eugène Delacroix (1798-1863)

Dois homens nus, sentado e de pé, a partir de

02 fotografias de Eugène Durieu (1800-1874)

Grafite sobre papel, $23 \times 27 \mathrm{~cm}$

Metropolitan Museum. Nova York

3

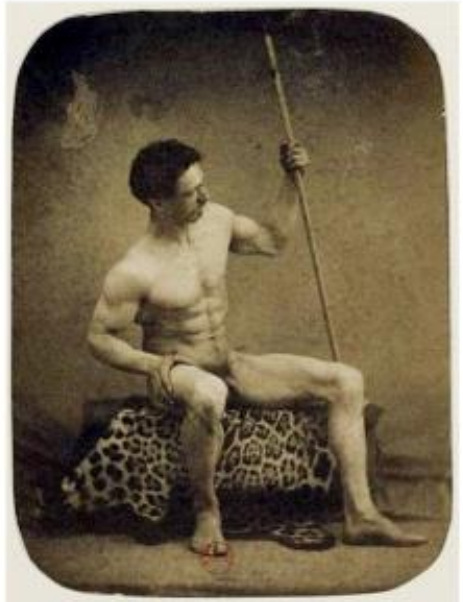

Eugene Durieu (1800-1874): Homem sentado (c. 1854) Biblioteca Nacional, Paris. 


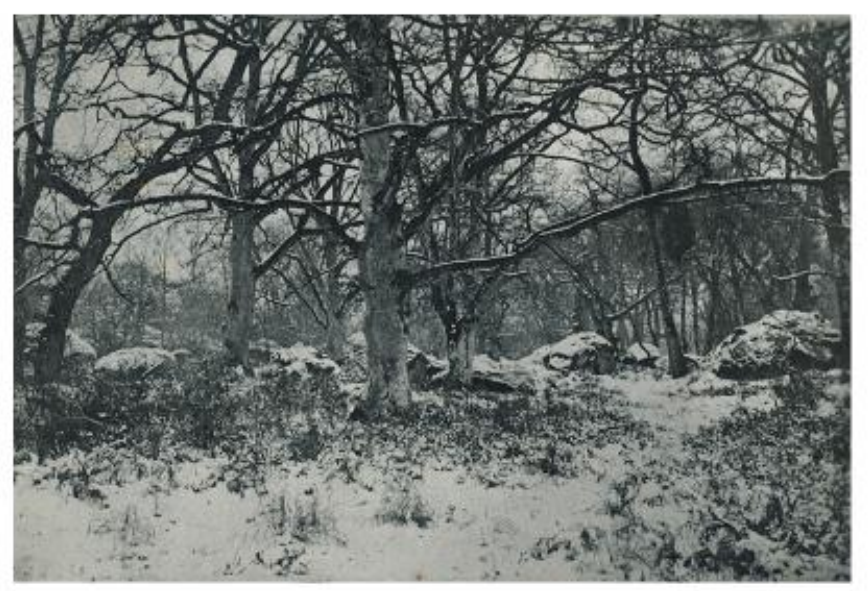

Photograph used by Cézanne for Neige fondante à Fontanebleau (image courtesy National Gallery of Art Photo Archives); unknown

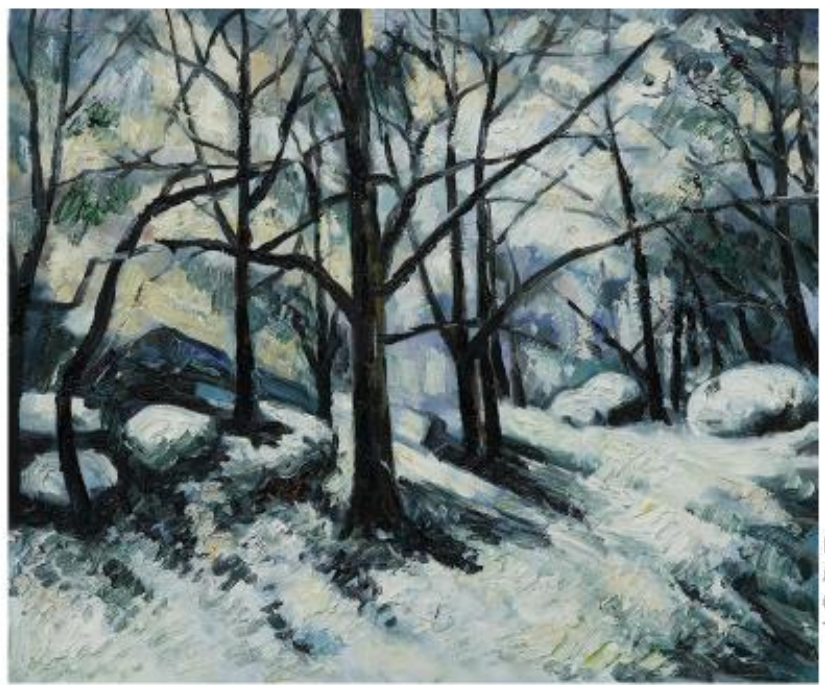

Paul Cézanne (1839-1906):

Neige fondanteà Fontainebleau, 1879-80

Oleo sobre tela, $(73.6 \times 100.6 \mathrm{~cm})$

The Museum of Modern Art, Nova York 


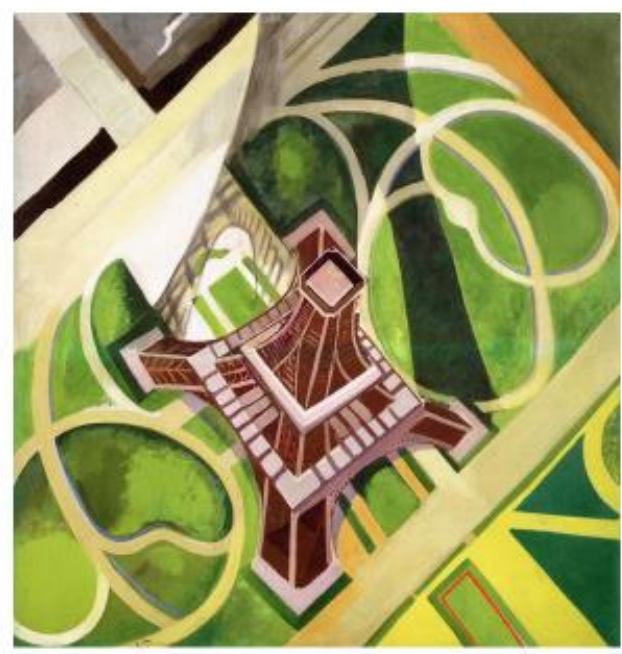

Robert Delaunay (1885-1941)

Torre Eiffel e os Jardins do Champ de Mars, 1922

óleo sobre tela, $178,1 \times 170,4 \mathrm{~cm}$

Hirshhorn Museum and Sculpture Garden -

Washington DC

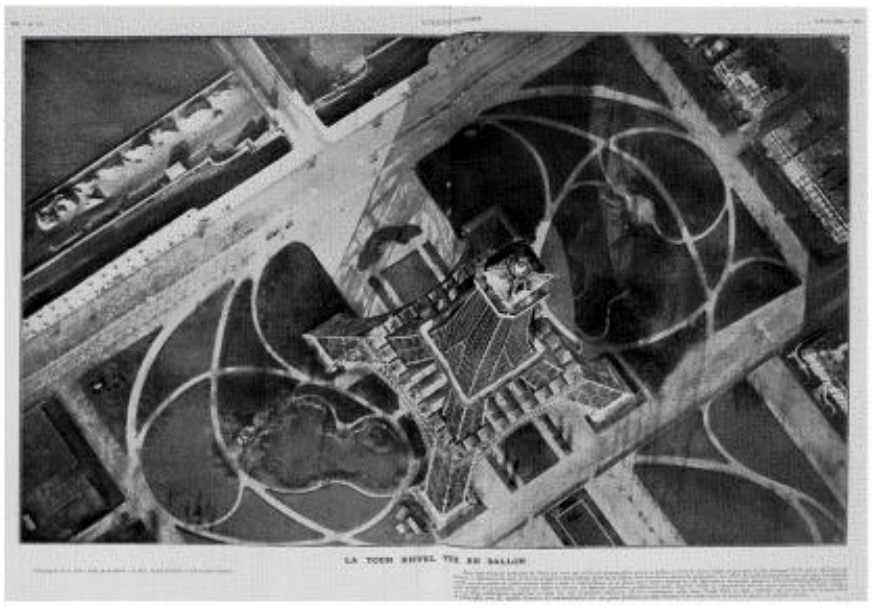

Andre Schelcher \& Albert Omer-Decugis

- La tour Eiffel vue en ballon - 1908 


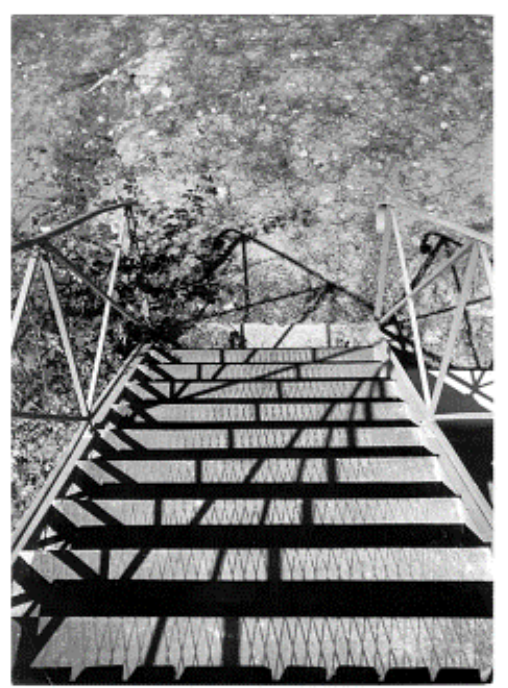

9

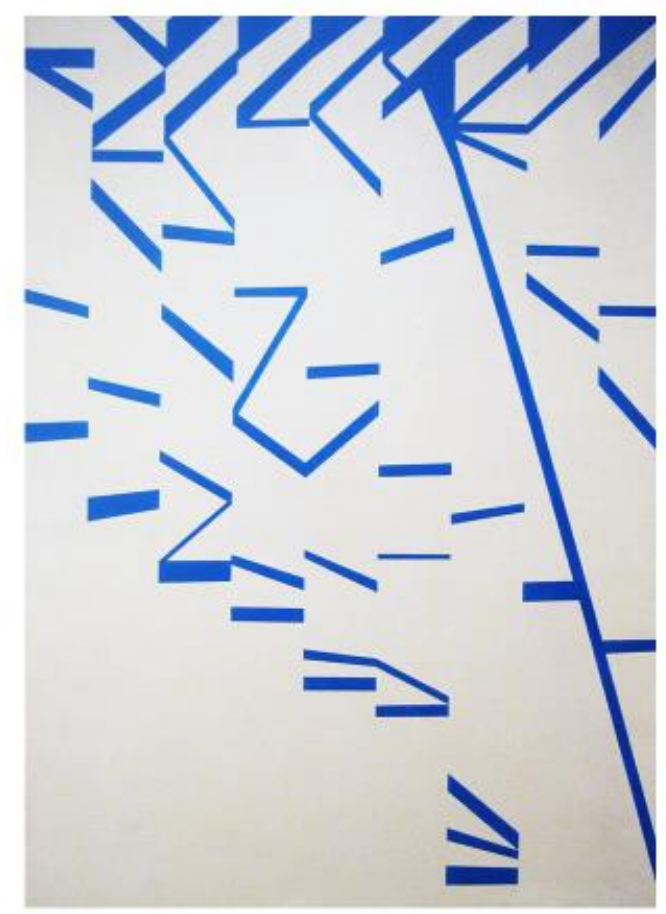

10
Ellsworth Kelly (1923-2015),

Shadows on Stairs, Villa La Combe, Meschers,

1950,

ilver gelatin print, $35.6 \times 27.9 \mathrm{~cm}$, Coleção do

artista
Ellsworth Kelly (1923-2015),

La Combe III, 1951

oil on linen, $161.29 \mathrm{~cm} \times 113.03 \mathrm{~cm}$

San Francisco Museum of Modern Art 


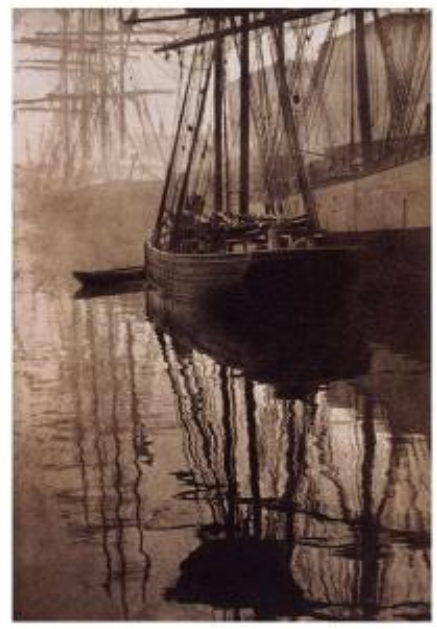

Alvin Langdon Coburn.

Photogravure,

publicada em Camera

Work, No 21, 1908

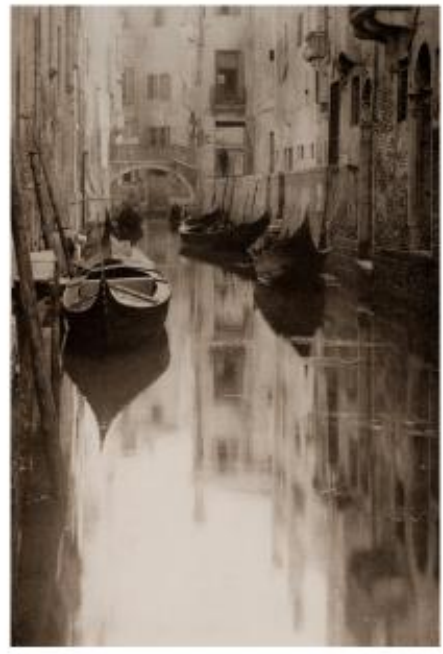

Alfred Stieglitz

"Venetian Canal" (1894)

12 


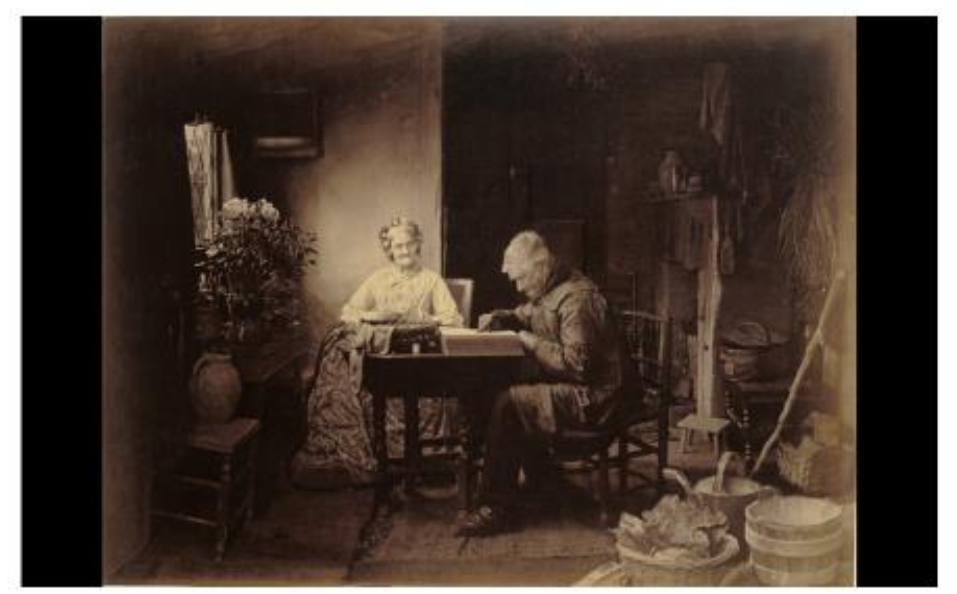

Henry Peach Robinson (1830 - 1901)

Quando o dia de trabalho termina (1877) Emulsão em prata.

Impressão feita a partir de seis negativos diferentes. $56 \times 74,5 \mathrm{~cm}$

The J. Paul Getty Museum , Los Angeles

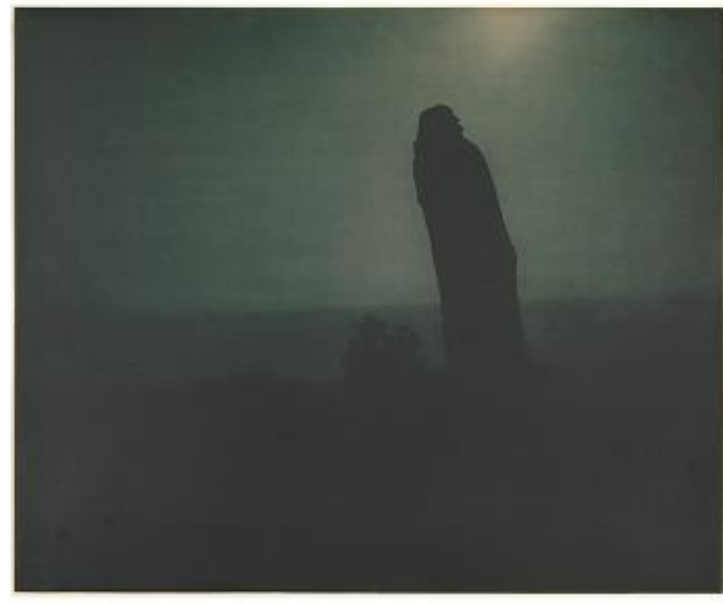

Edward J. Steichen (1879-1973)

Balzac, a silhueta as 04 horas, 1908

Impressão de goma bicromada, $37,9 \times 46 \mathrm{~cm}$

Metropolitan Museum, Nova York 


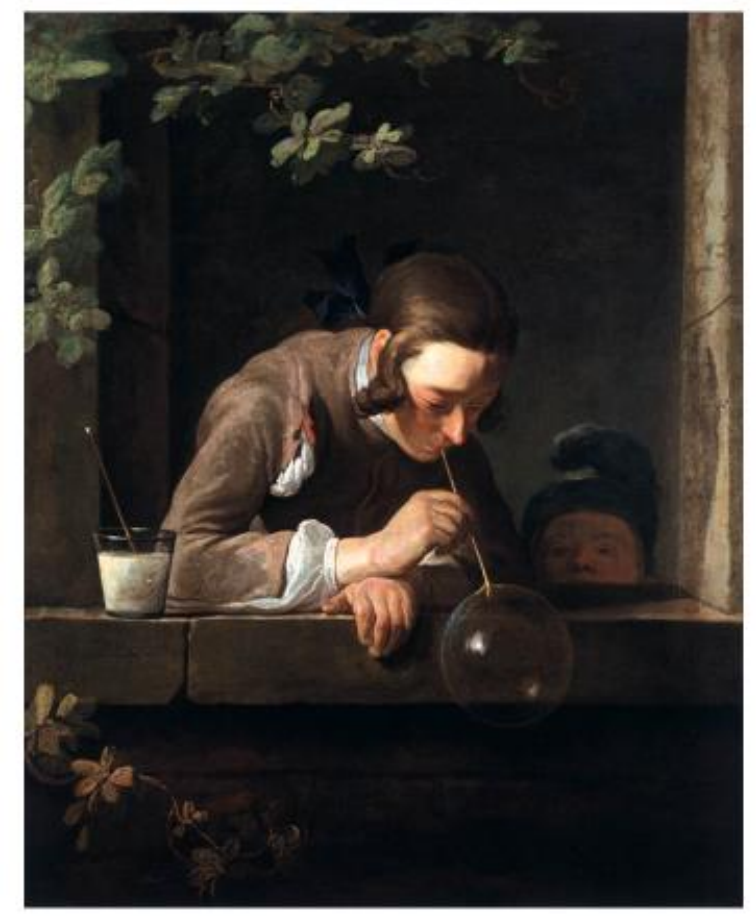

15

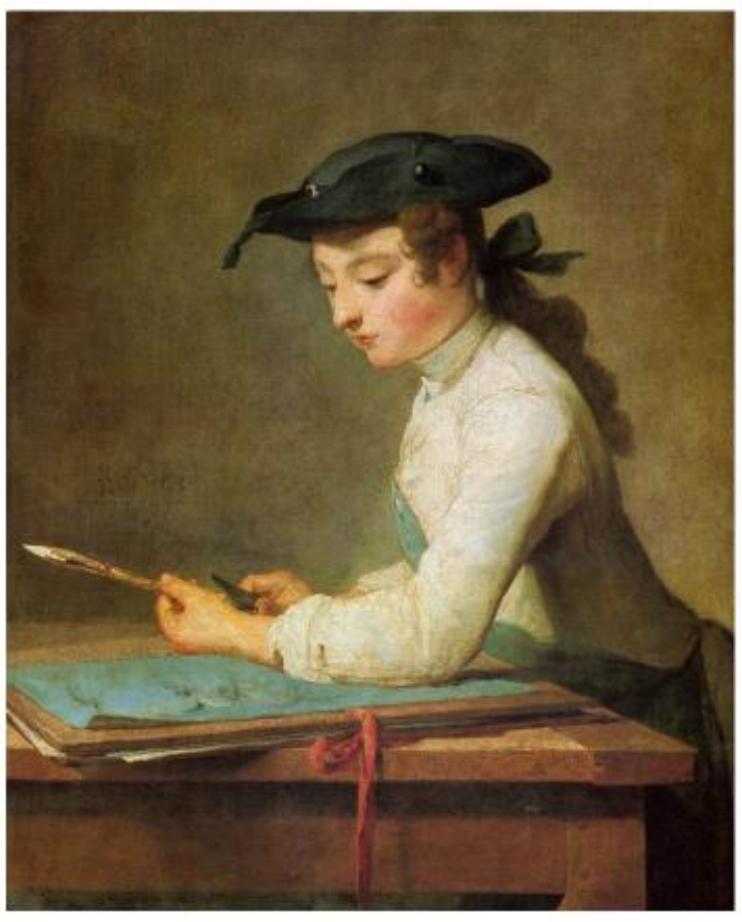

16 


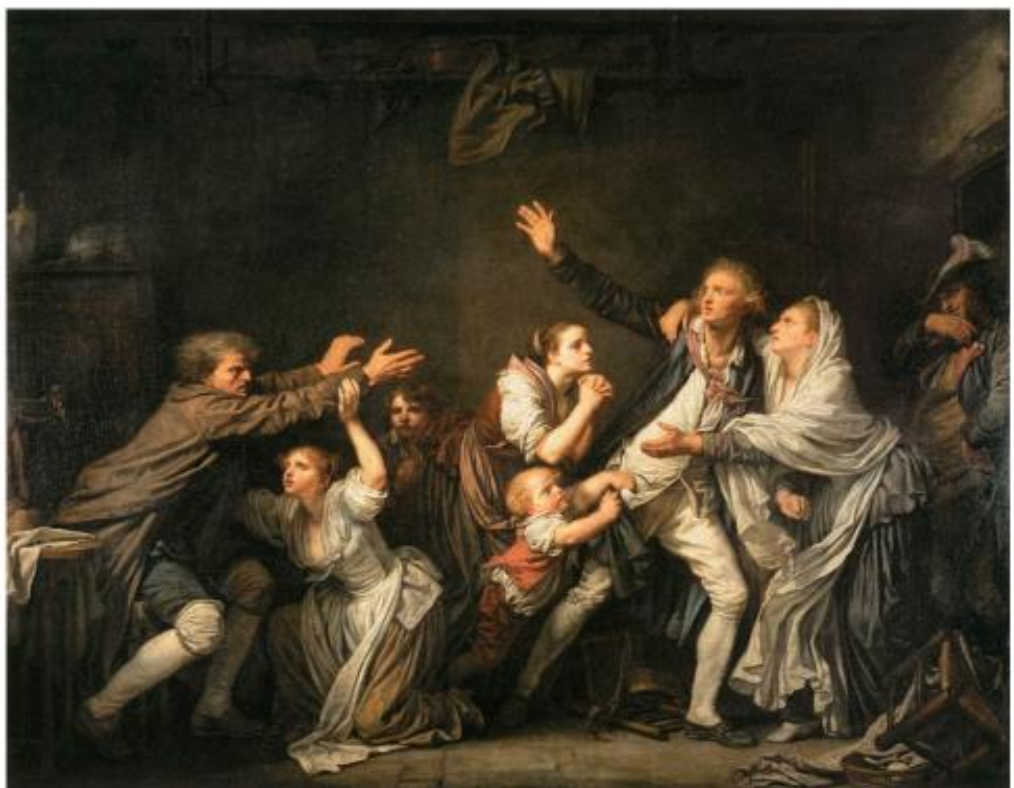

Jean-Baptiste Greuze The Father's Curse: The Ungrateful Son (1777) $130 \times 162 \mathrm{~cm}$

17 Musée du Louvre, Paris

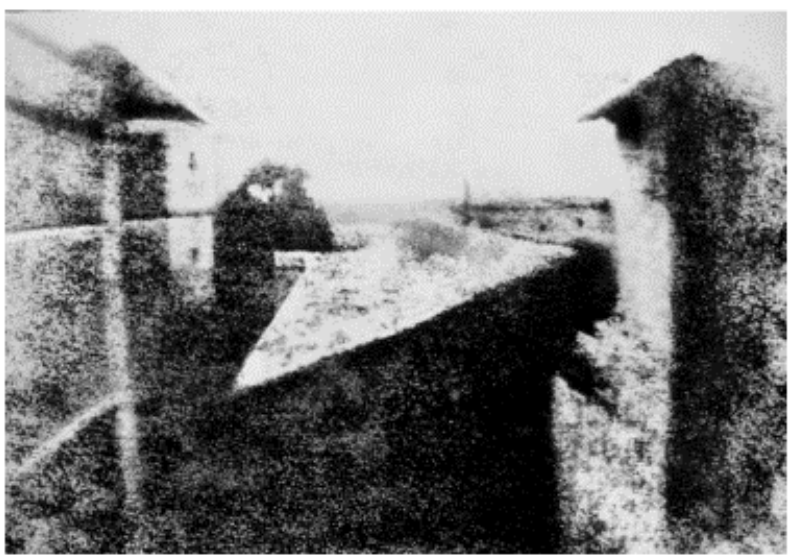

Joseph Nicéphone Niepce

Heliogravura de 1862 


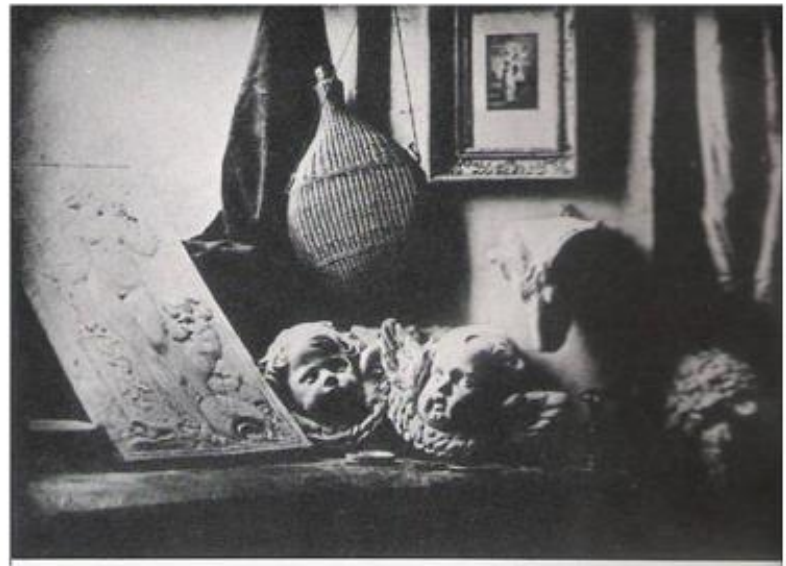

Jacques Louis Daguerre:

O estúdio fotográfico (1867)

Daguerreótipo

Chapa de prata sensibilizada

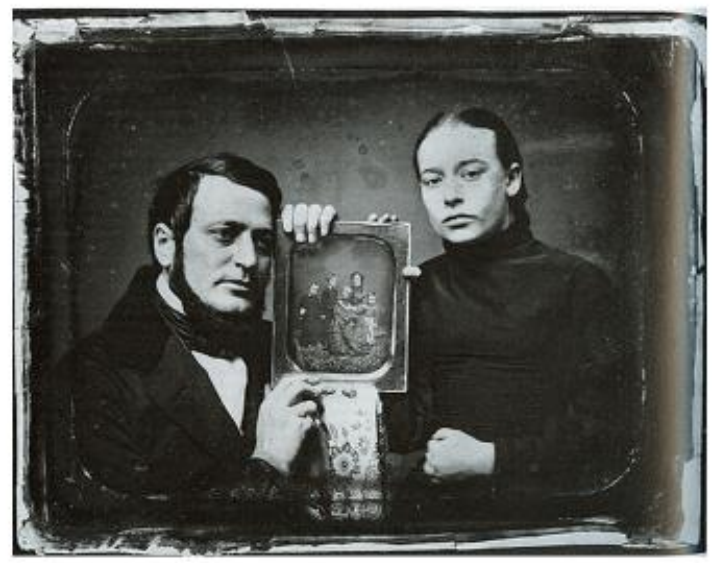

J.L.M. Daguerre: Daguerreótipo, c. 1850 


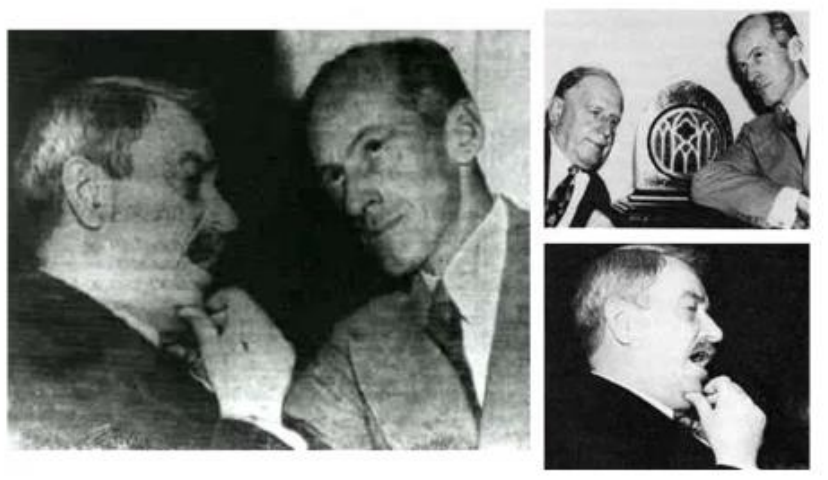

Photo-composite: O senador Millard Tydings aparentemente representadoem 1950 com Earl Browder, ex-chefe do Partido Comunista dos EUA. Na verdade, eles nunca se conheceram.

21
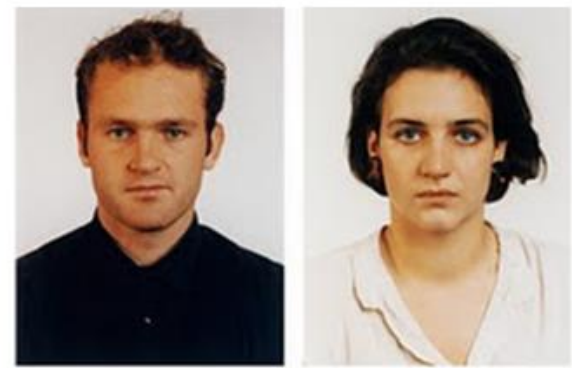

22

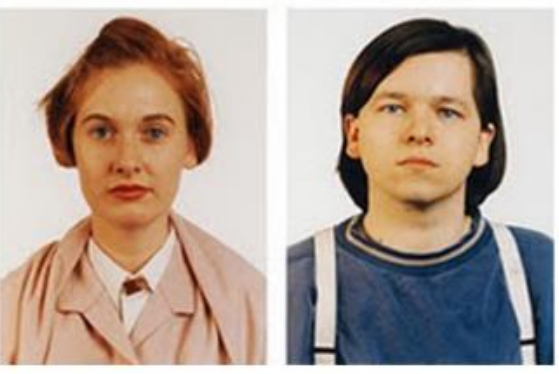

Thomas Ruff

fotos de passaporte (década de

1980)

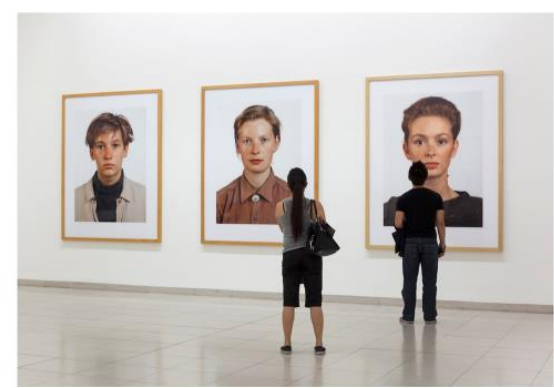

23 


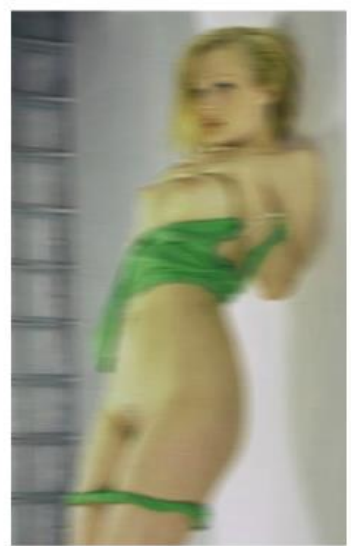

Thomas Ruff

nude (ap 14)

$2001 / 2009$

Lambda c-print

$11.81 \times 15.75$ inches

$30 \times 40 \mathrm{~cm}$

24

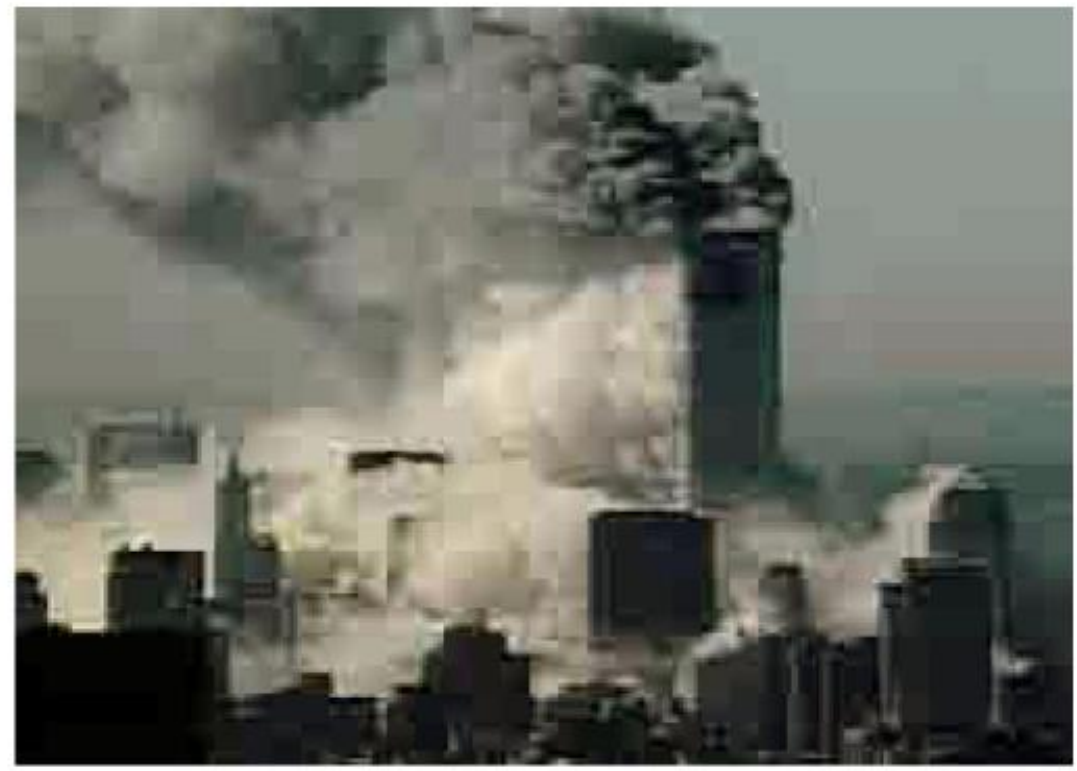

Thomas Ruff: jpeg ny02 (2004)

Chromogenic print, $269 \times 364 \mathrm{~cm}$

25

The Metropolitan Museum of Art, Nova York 


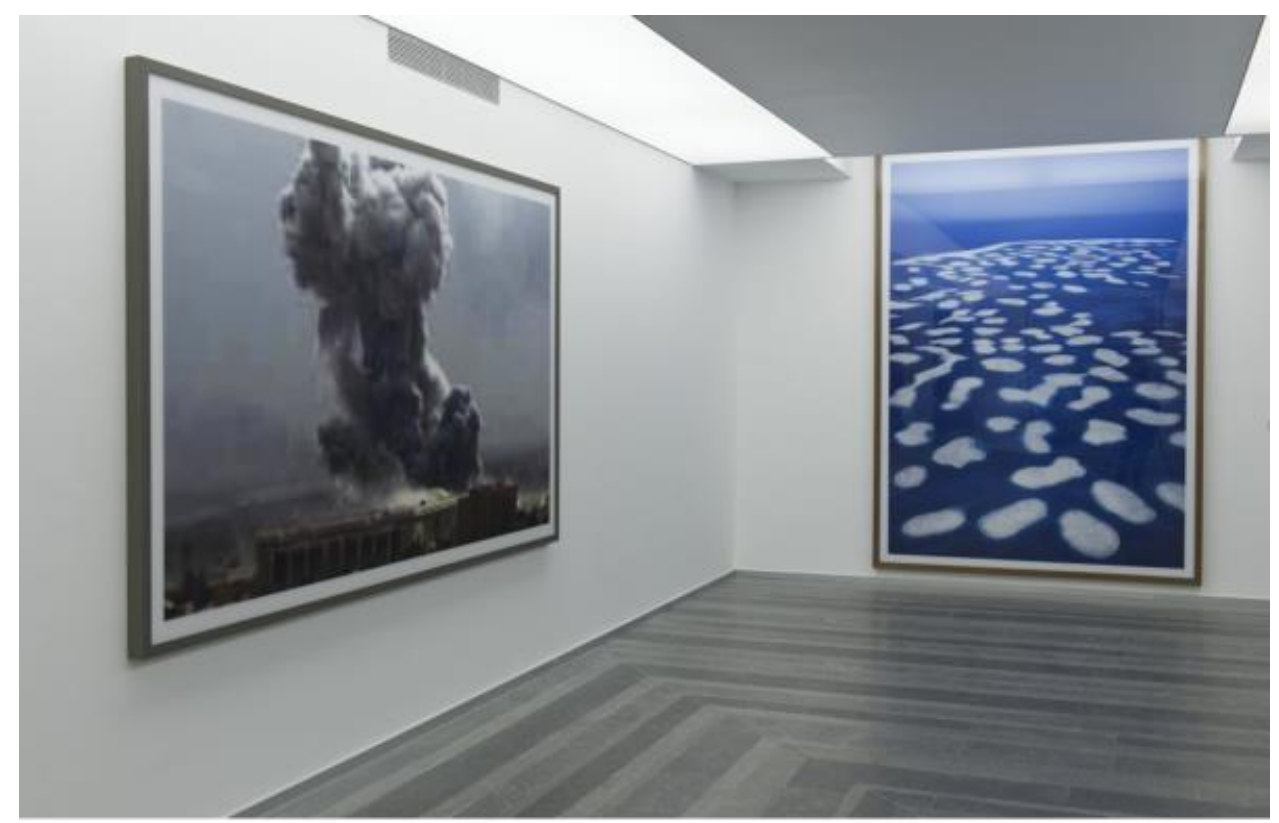

26

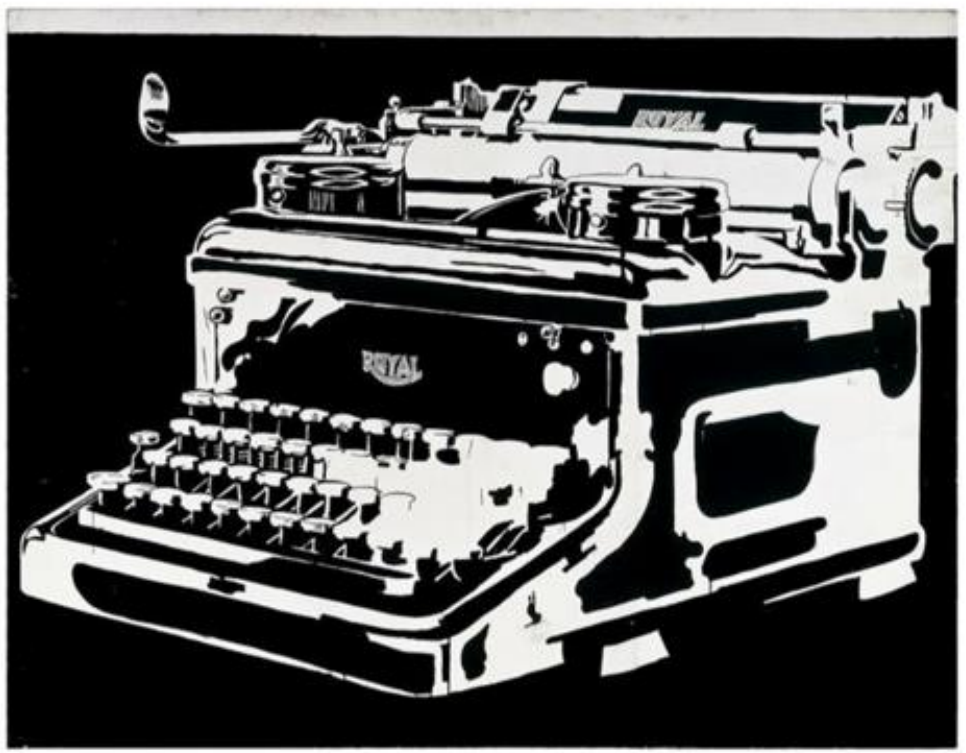

Andy Warhol Typewriter (1), 1961. 


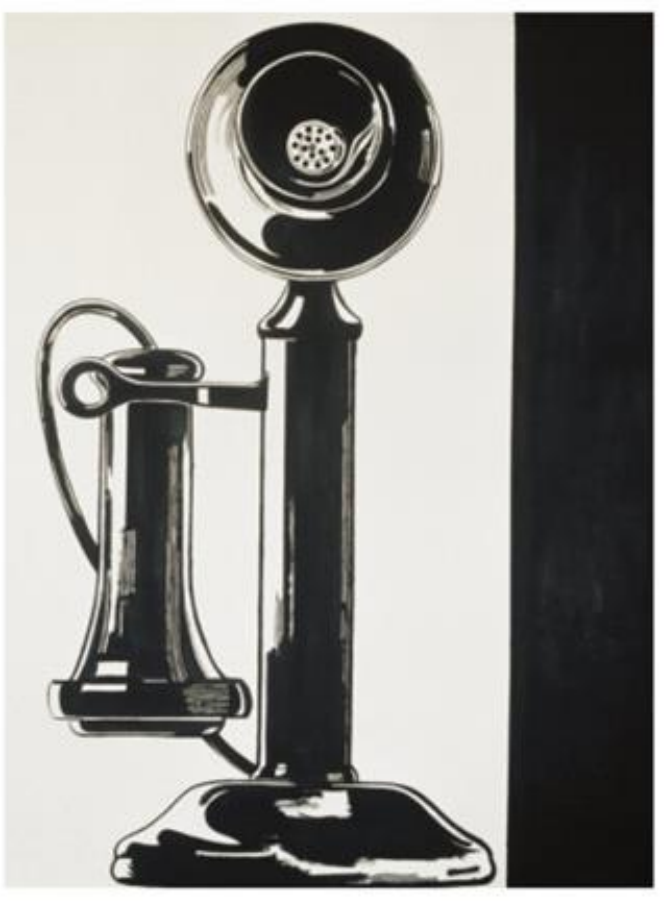

Telephone (1961)

Óleo sobre tela

$177.2 \times 137.2 \mathrm{~cm}$

Andy Warhol Museum,

Pittsburgh

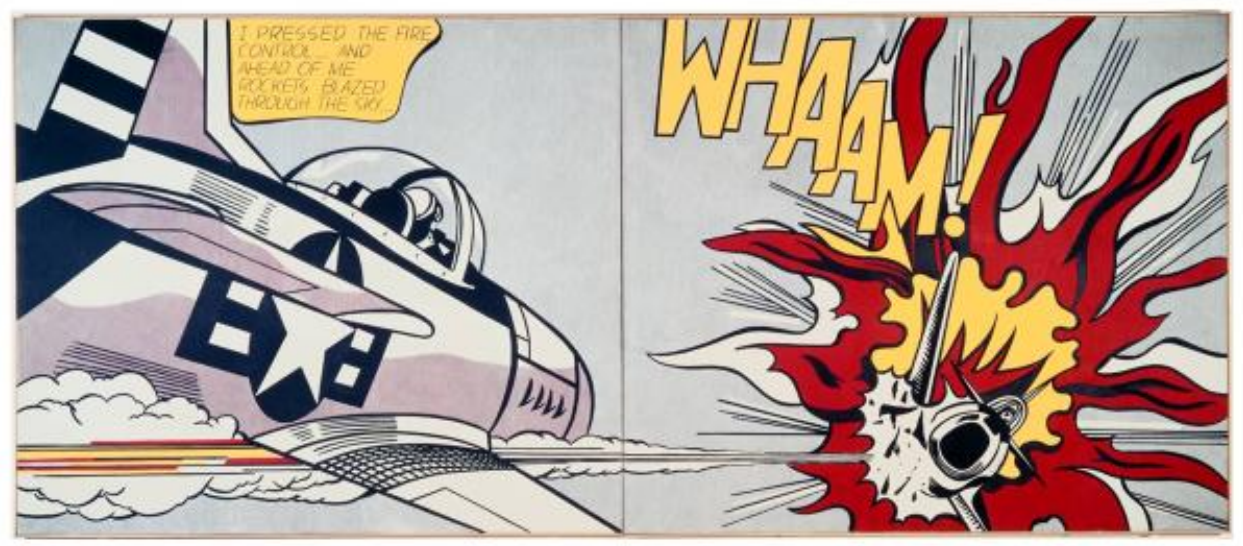

Roy Lichtenstein (1923-1997): Whamm!, 1963

Magna on canvas, $172.7 \times 406.4 \mathrm{~cm}$

Tate, Londres 


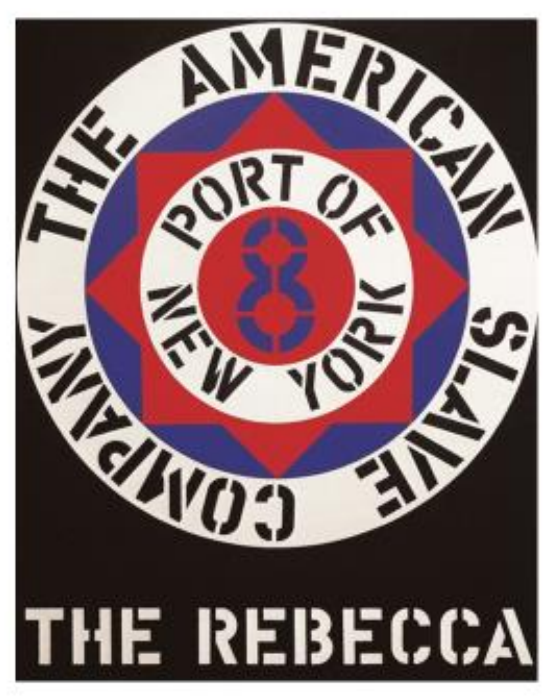

30
Robert Indiana (1928)

The Rebecca, 1962

Óleo sobre tela

$152.4 \times 122 \mathrm{~cm}$

Morgan Art Foundation

Zurique

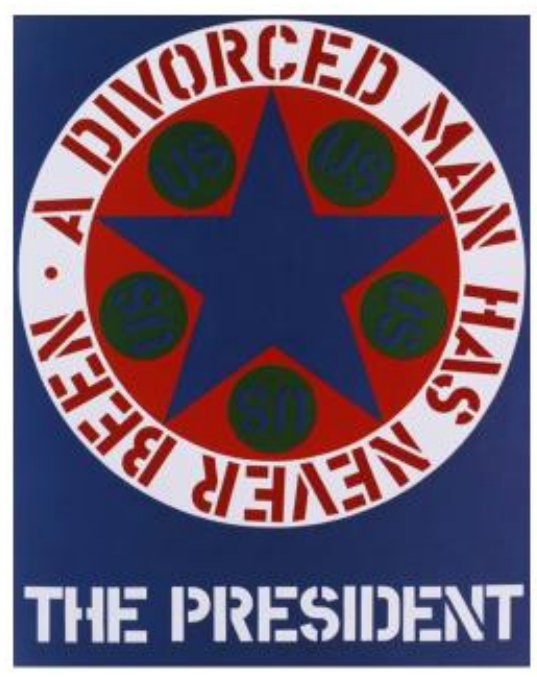

Robert Indiana (1928) A DIVORCED MAN HAS NEVER BEEN THE PRESIDENT, 1961

OLL ON CANVAS

$68 \times 48 \mathrm{IN}$

$[172.7 \times 121.9 \mathrm{~cm}$.]

SHELDON MEMORIAL ART

GALLERY, UNIVERSITY OF

NEBRASKA-LINCOLN, GIFT OF PHILIP JOHNSON, 1968 


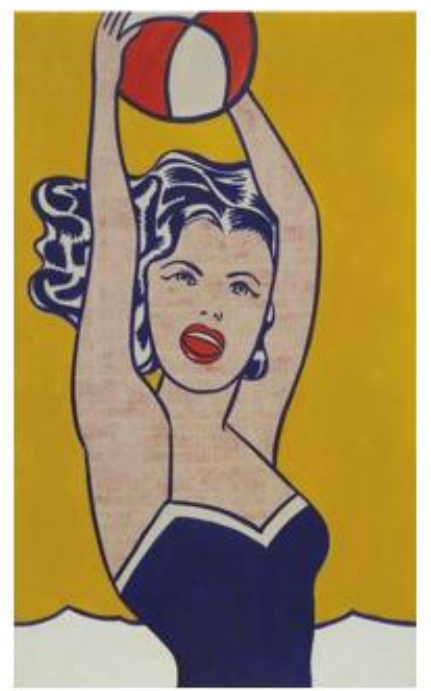

Roy Lichtenstein (American, 1923-1997)

Girl with Ball , 1961

Óleo sobre tela

$153 \times 91.9 \mathrm{~cm}$

Museum of Modern Art, Nova York.

32

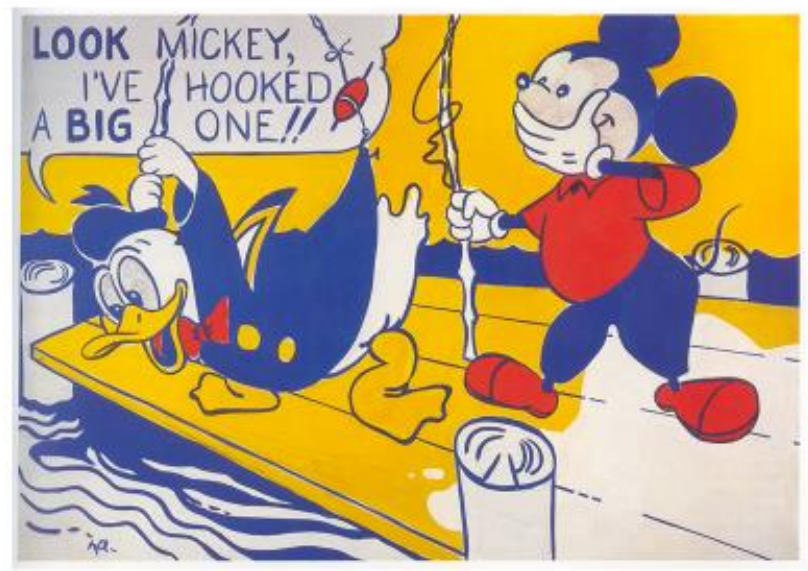

Roy Lichtenstein Look Mickey(1961)

Oil on canvas

$121.9 \times 175.3 \mathrm{~cm}$

The National Gallery of Art, Washington 

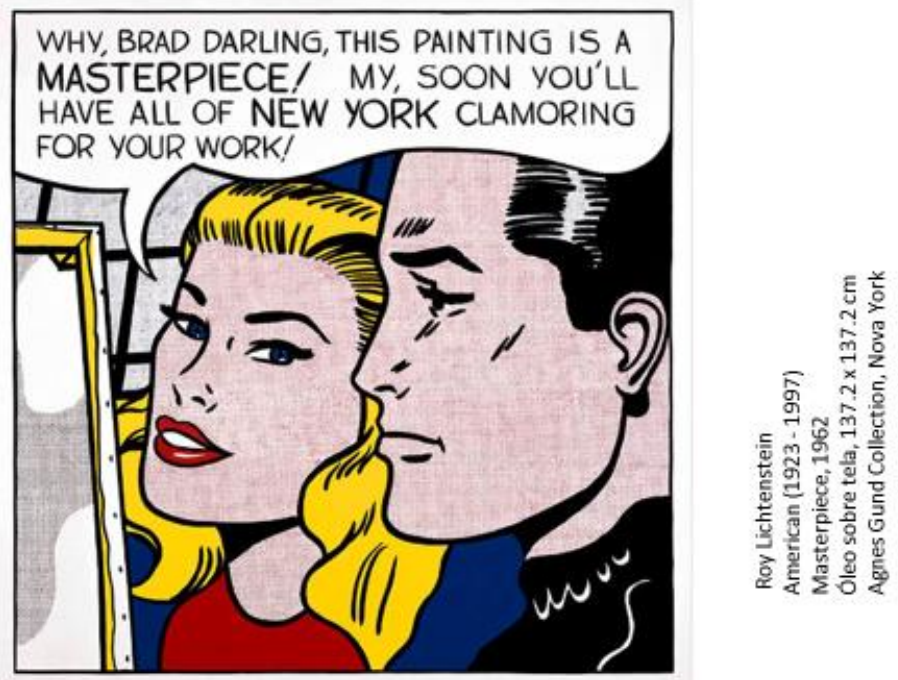

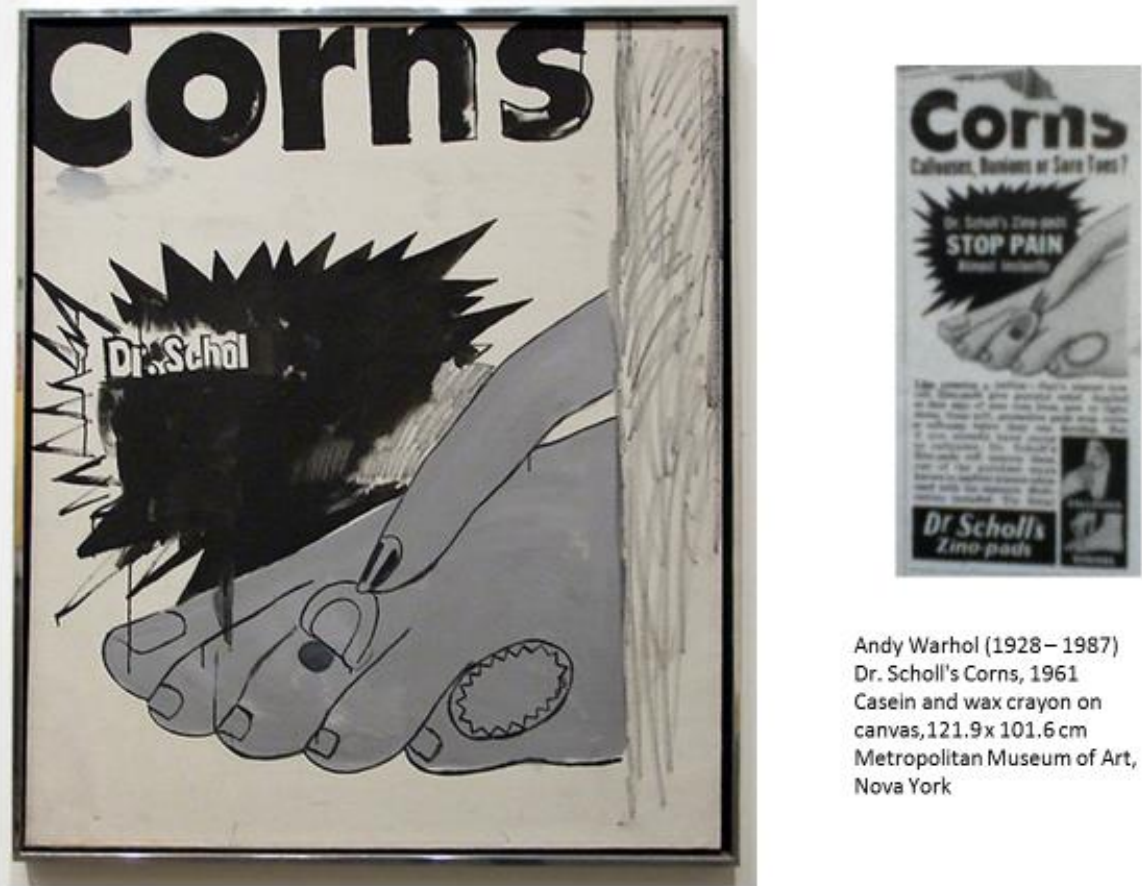

Andy Warhol (1928- 1987)

Dr. Scholl's Corns, 1961

Casein and wax crayon on

canvas, $121.9 \times 101.6 \mathrm{~cm}$

Metropolitan Museum of Art,

Nova York

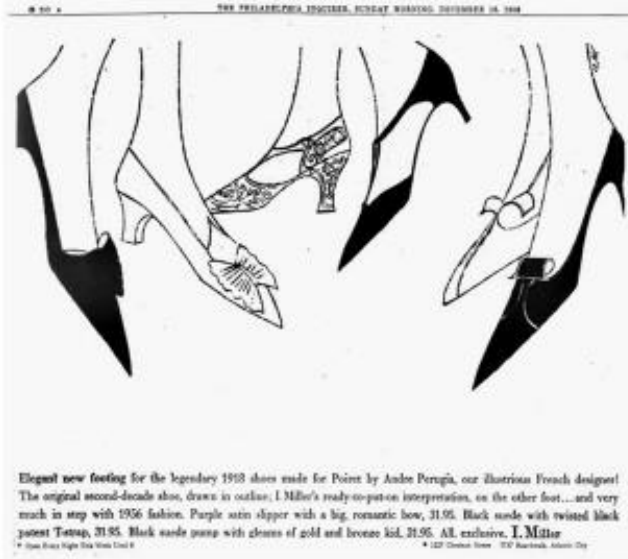

Andy Warhol (1928-1987) Anúncio da I. Miller de 1956

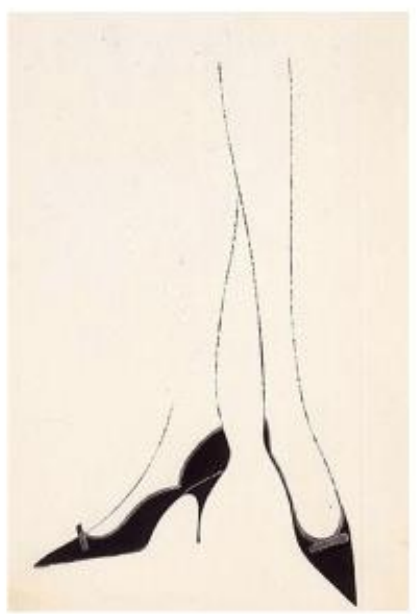

Andy Warhol (1928 - 1987): Sem título (1956) Tinta no papel Strathmore, $58,4 \times 41,6 \mathrm{~cm}$ 

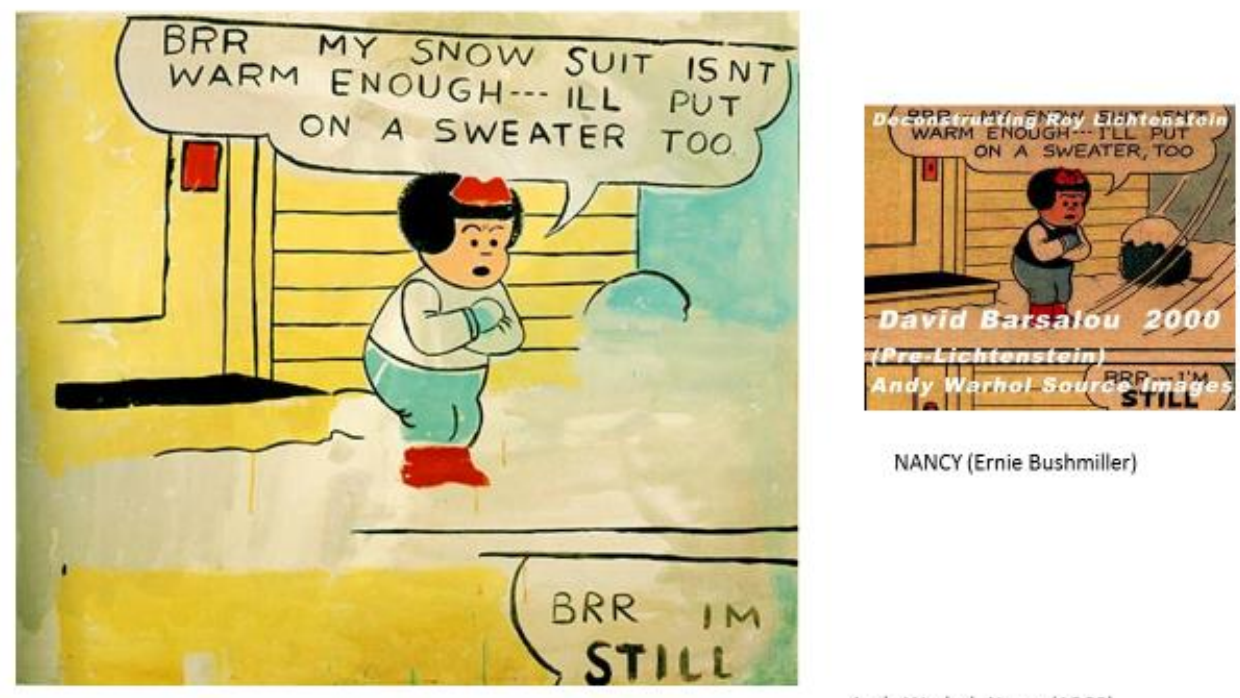

NANCY (Ernie Bushmiller)

Andy Warhol, Nancy (1960)

Esmalte sobre tela, $101,5 \times 137,1 \mathrm{~cm}$.

Coleção particular

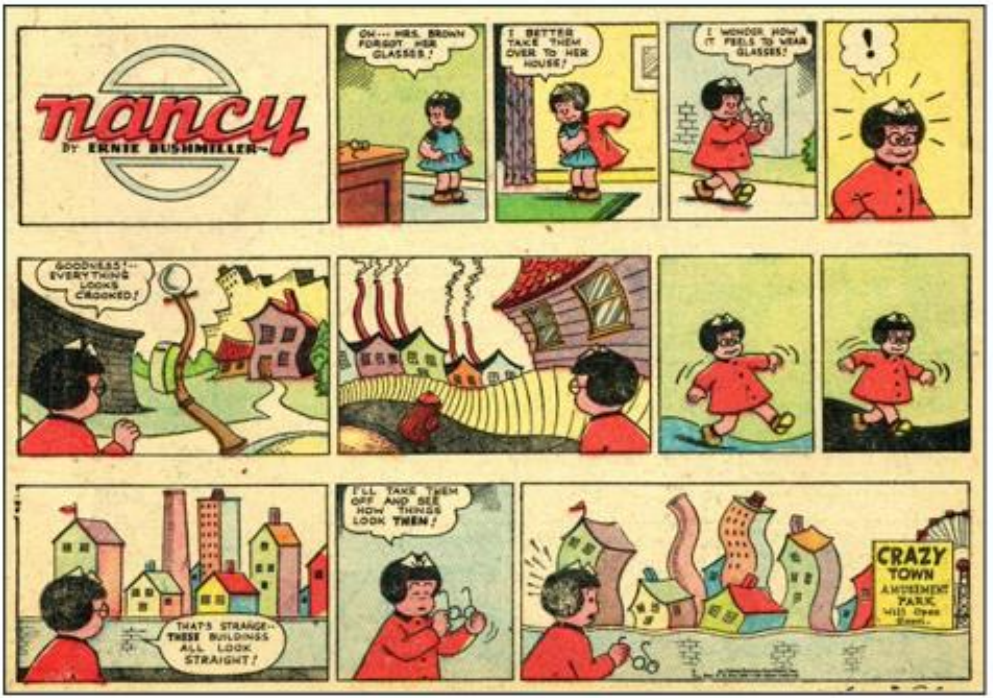

1948 

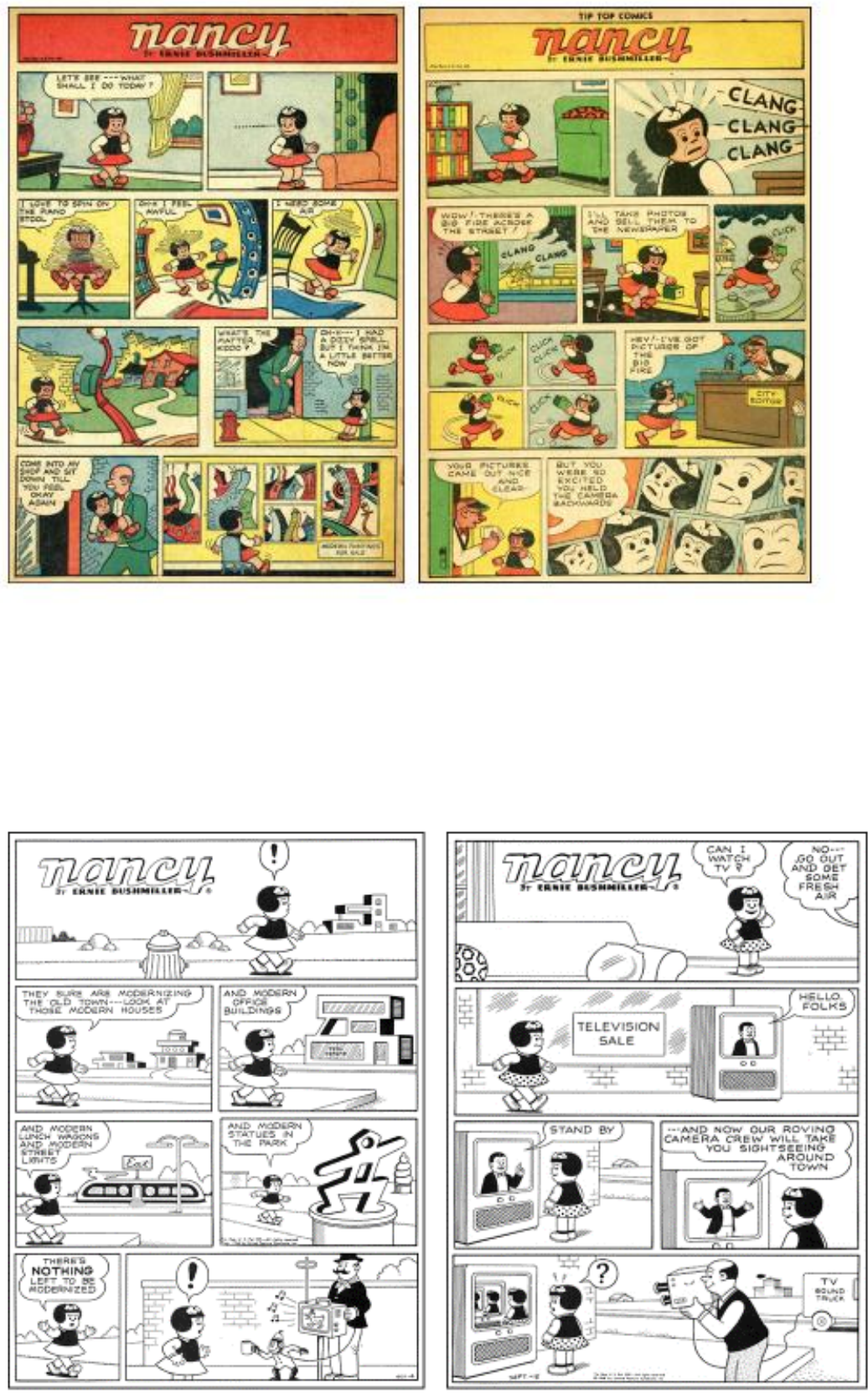


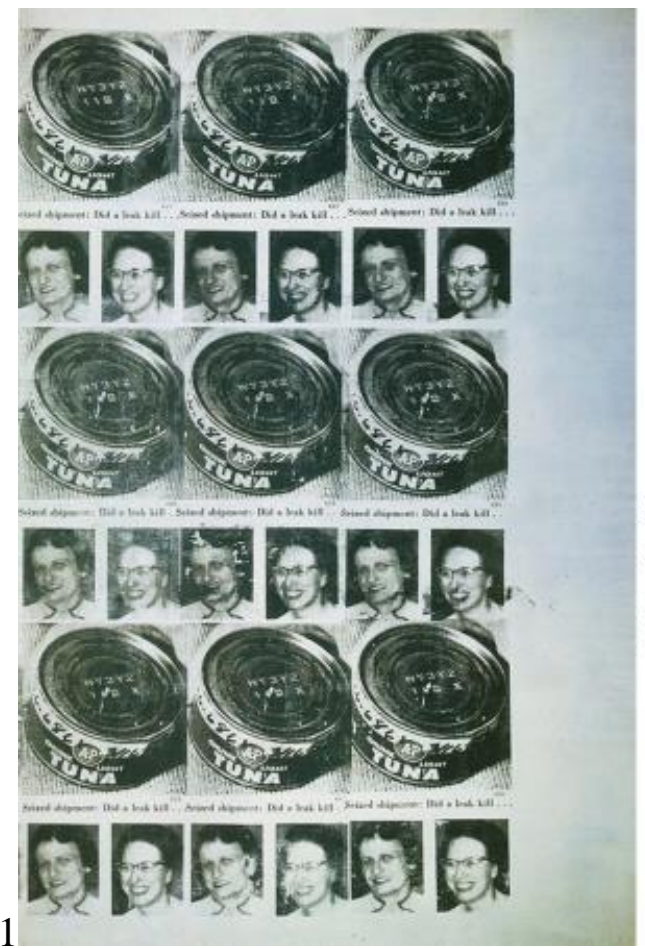

Andy Warhol

Tunafish Disaster, 1963

Synthetic polymer paint and

silkscreen on canvas, $316 \times 211 \mathrm{~cm}$

Saatchi Gallery, Londres

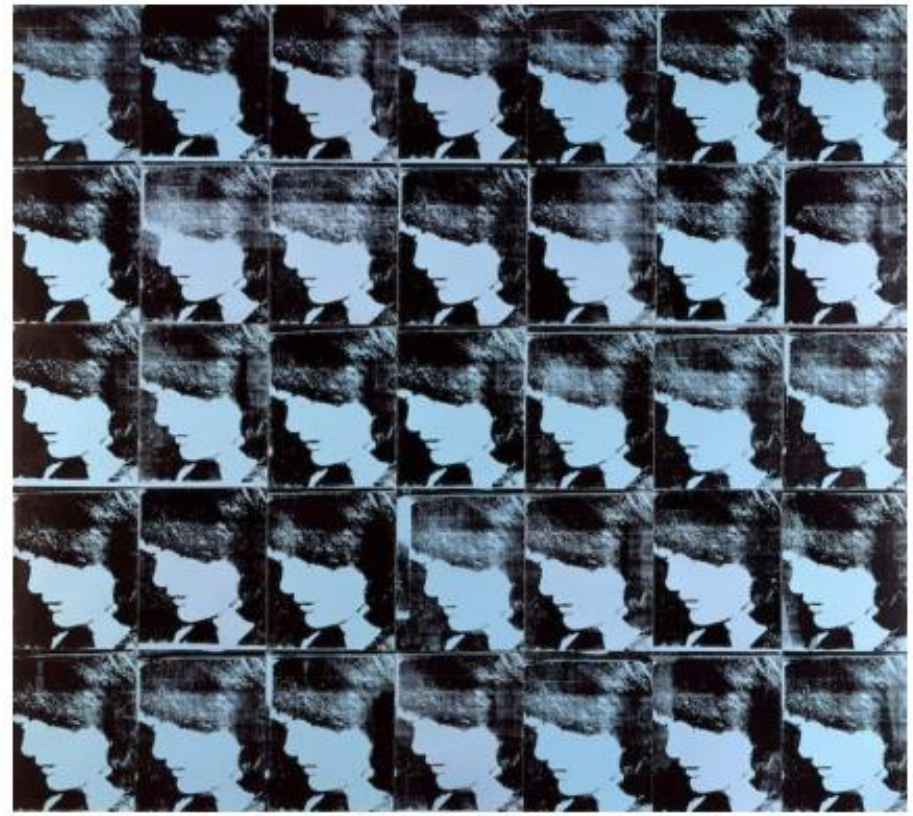

Andy Warhol: Thirty-Five Jackies (Multiplied Jackies), 1964

silkscreen and acrylic on canvas, $255,7 \times 286,8 \mathrm{~cm}$

MMK Museum für Moderne Kunst Frankfurt am Main 


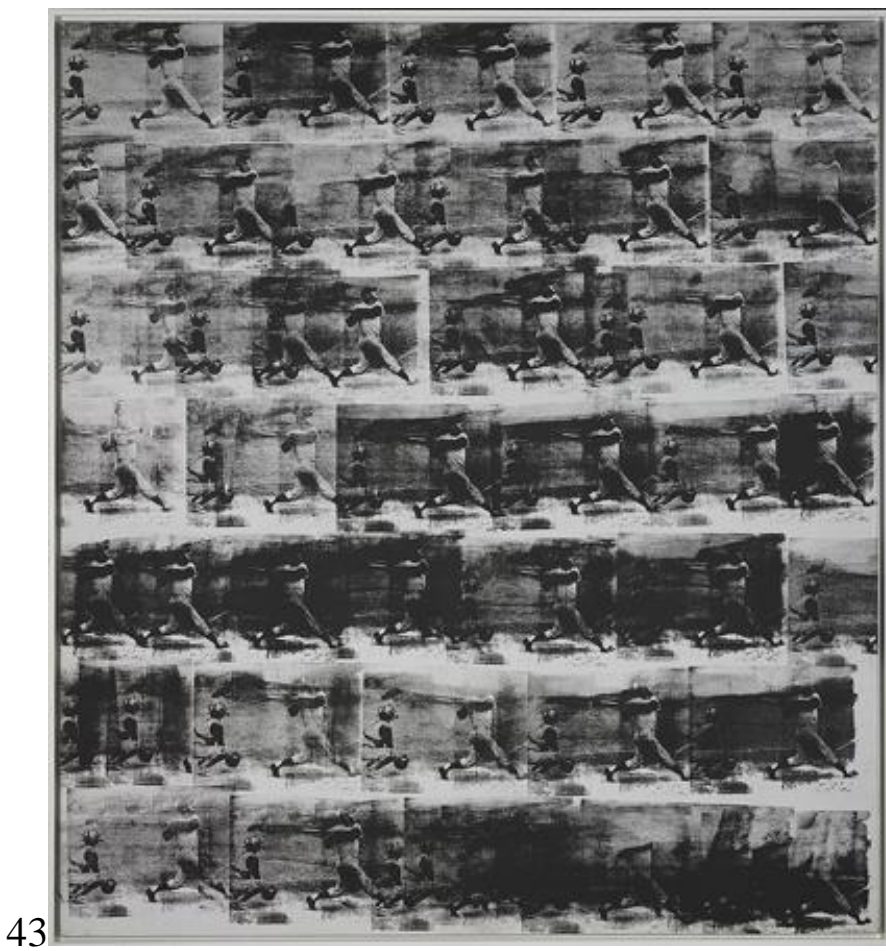

Andy Warhol (1928-1987).

Baseball, 1962 (Agosto).

Silkscreen and oil on

canvas

$232,41 \times 208,28 \mathrm{~cm}$

The Nelson-Atkins Museum

of Art

Kansas City

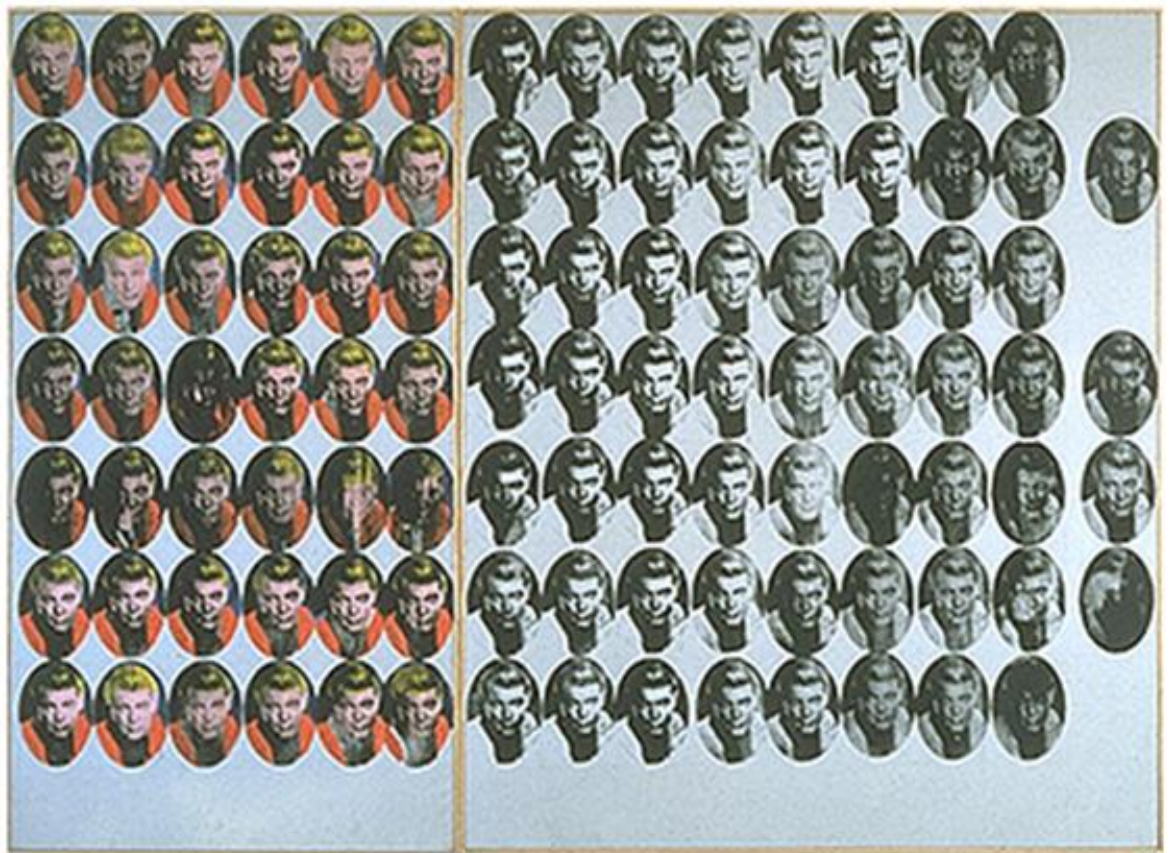

Da série Teen Idols: Diptico Troy Donahue (1962) Silkscreen ink on synthetic polymer paint

on canvas $(205.7 \times 281.3 \mathrm{~cm})$. Museum of Contemporary Art Chicago 


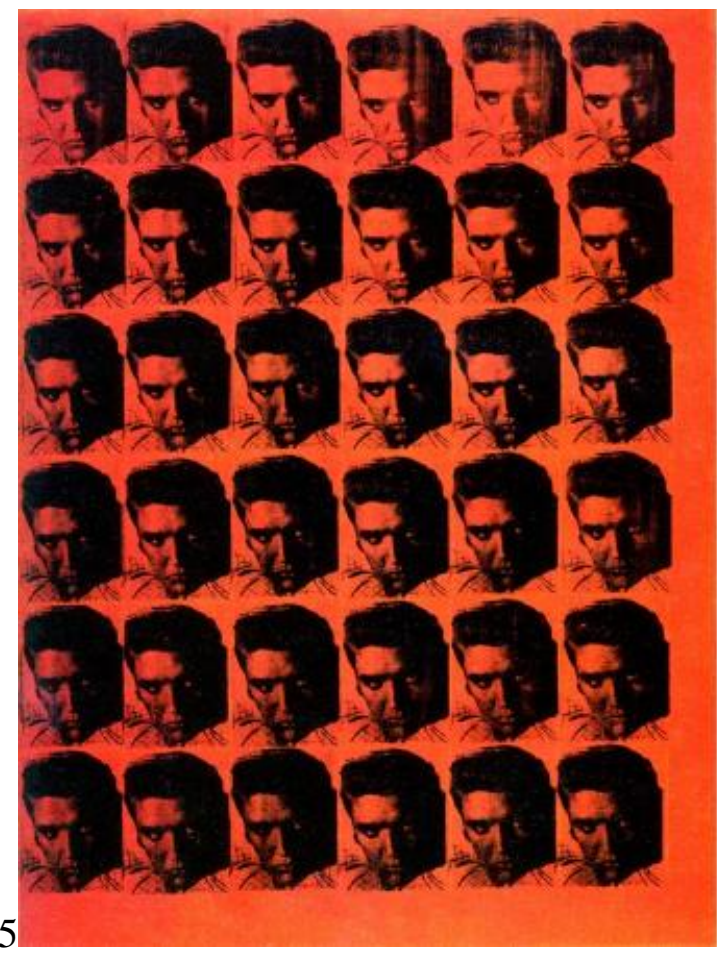

Andy Warhol "Red Elvis" (c.1962)

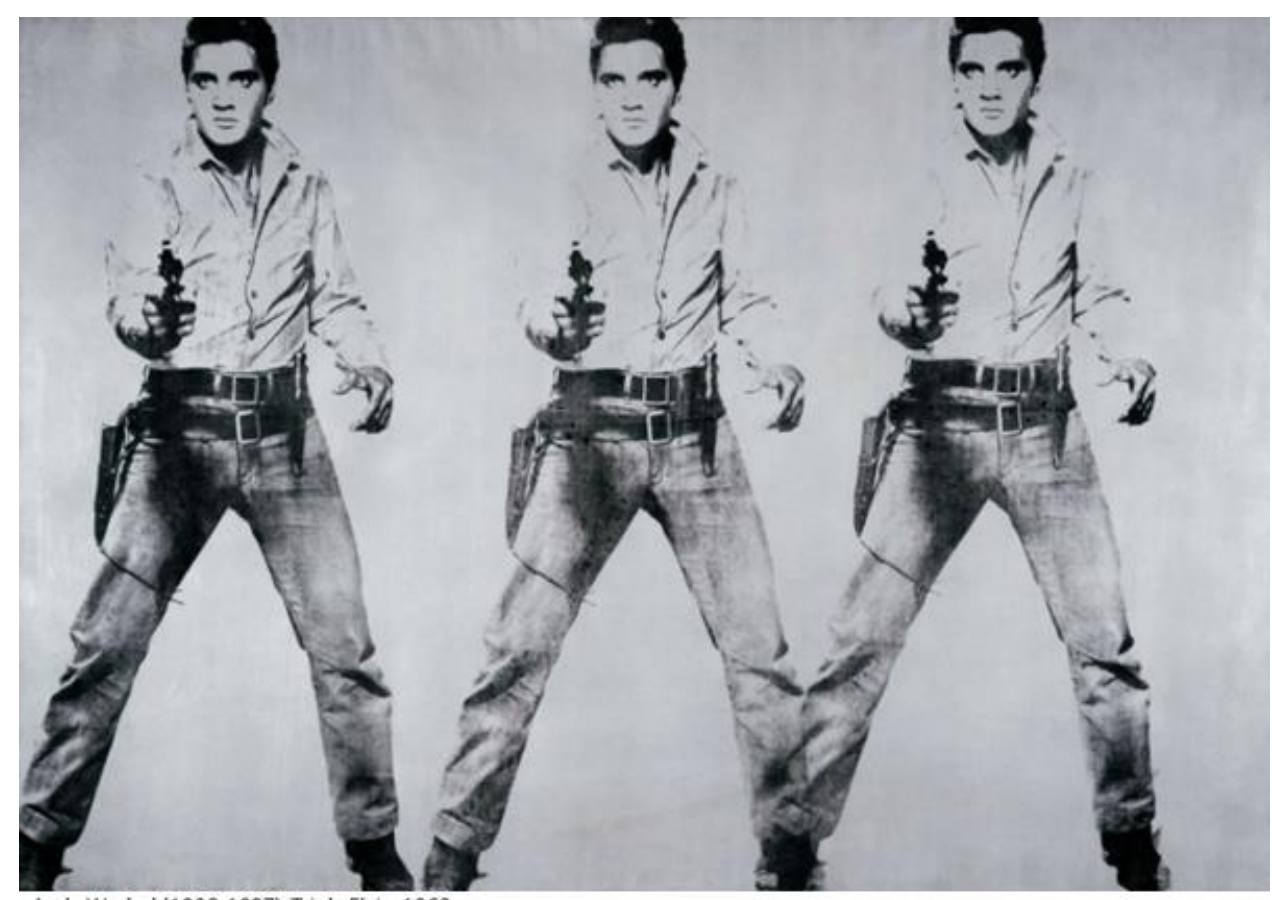
Andy Warhol (1928-1987): Triple Elvis, 1962

46 Acrylic silkscreened on canvas, $208.3 \times 299.7 \mathrm{~cm}$. San Francisco Museum of Modern Art 


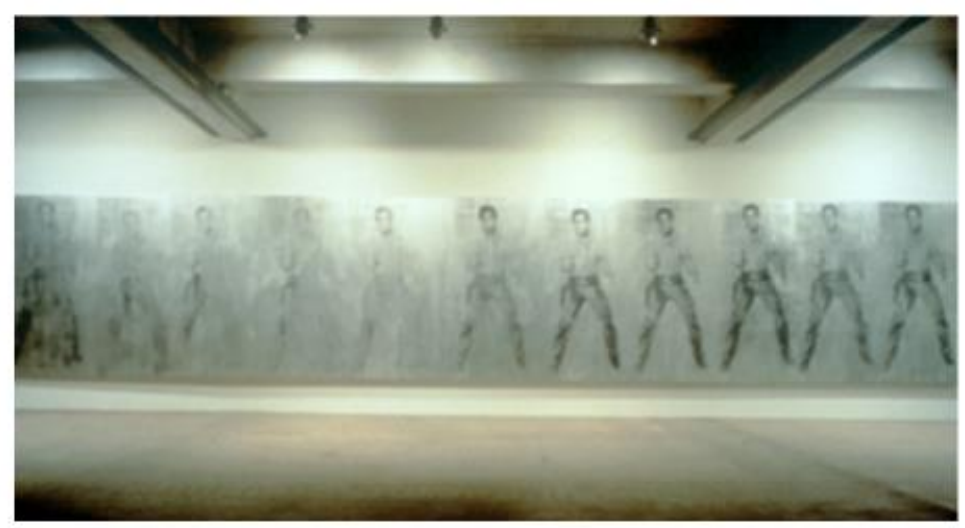

11 elvises, no Andy Warhol Museum

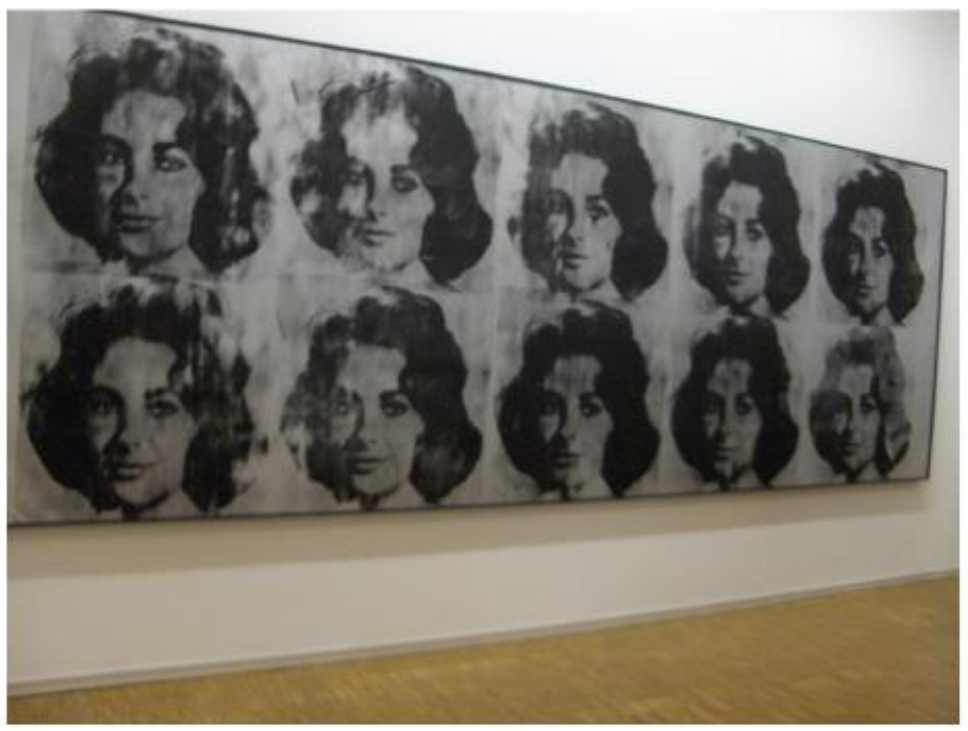

48 

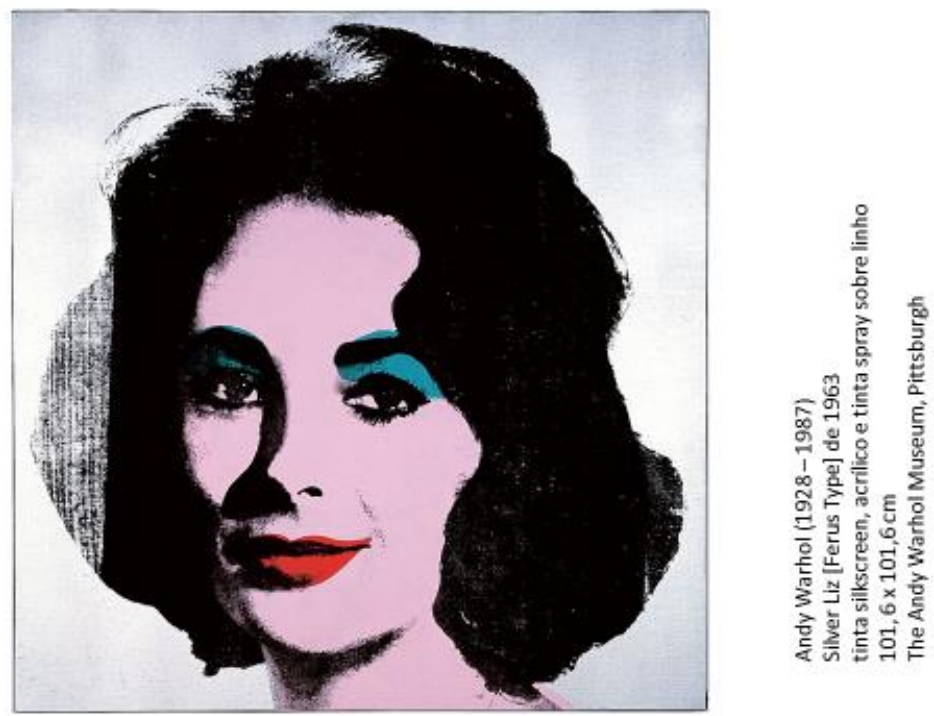

49

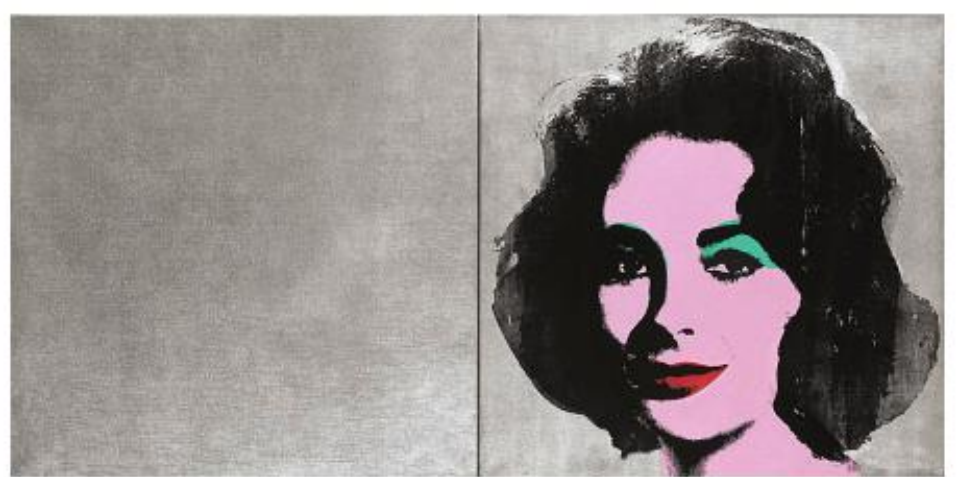

Silver Liz (1965)

$101,6 \times 203,2 \mathrm{~cm}$

Coleção privada 


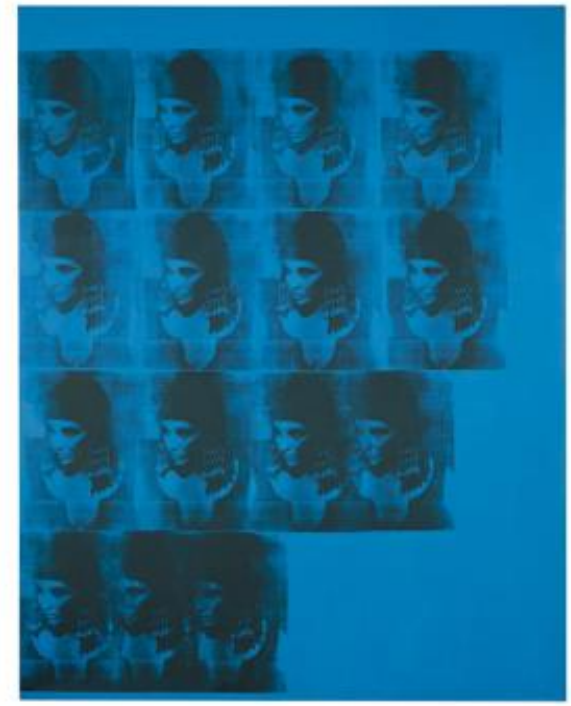

Andy Warhol (1928- 1987)

Blue Liz as Cleopatra, 1962

Acrylic, silkscreen ink, and pencil on

linen. $209.6 \times 165.1 \mathrm{~cm}$

Daros Collection, Switzerland

51

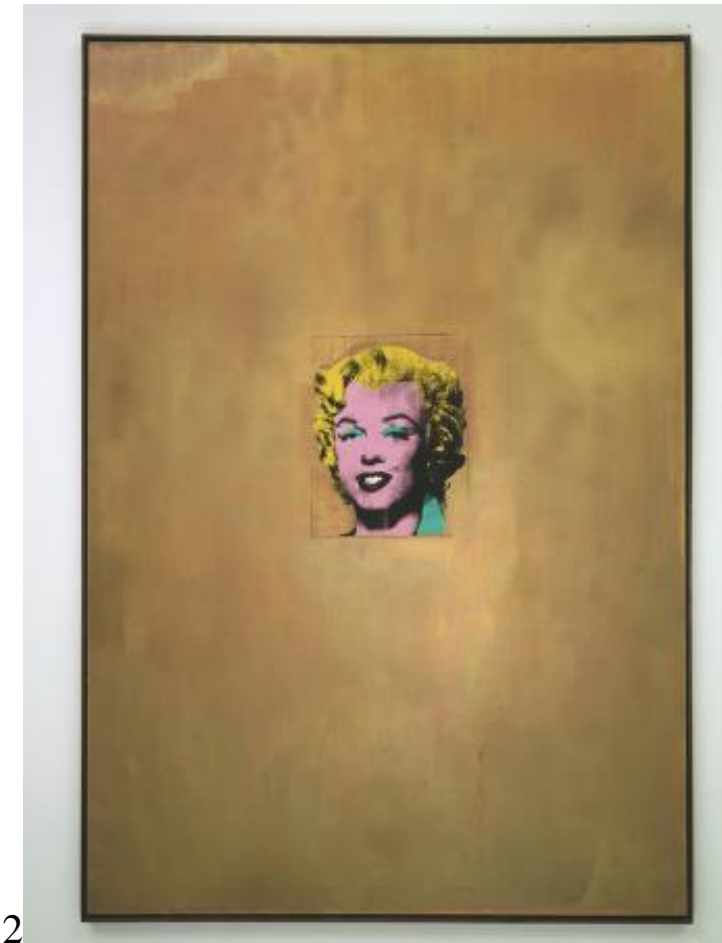

Andy Warhol

Goid Marilyn Monroe, 1962

Silkscreen ink on synthetic

polymer paint on canvas

Dimensions:

$(211.4 \times 144.7 \mathrm{~cm})$

The Museum of Modern Art

52 


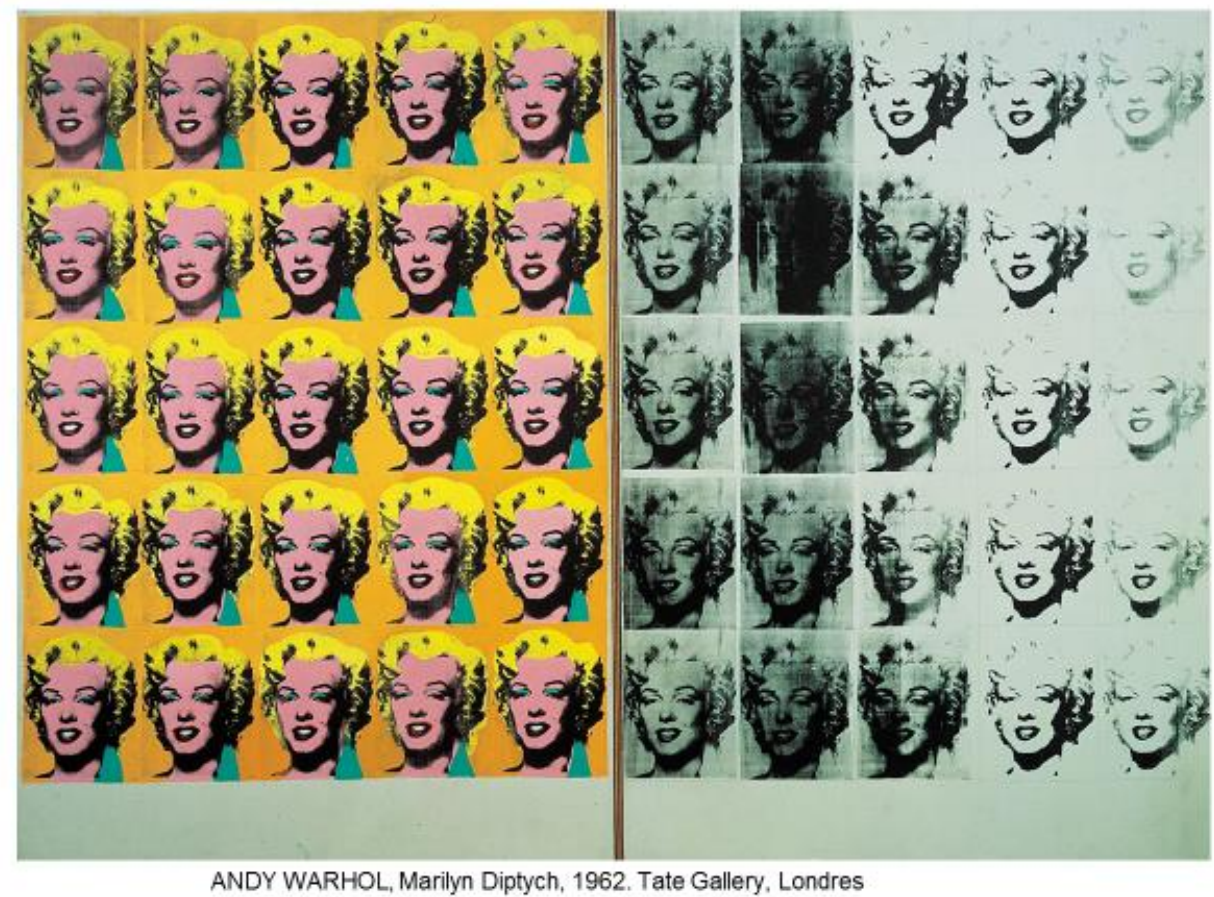

53

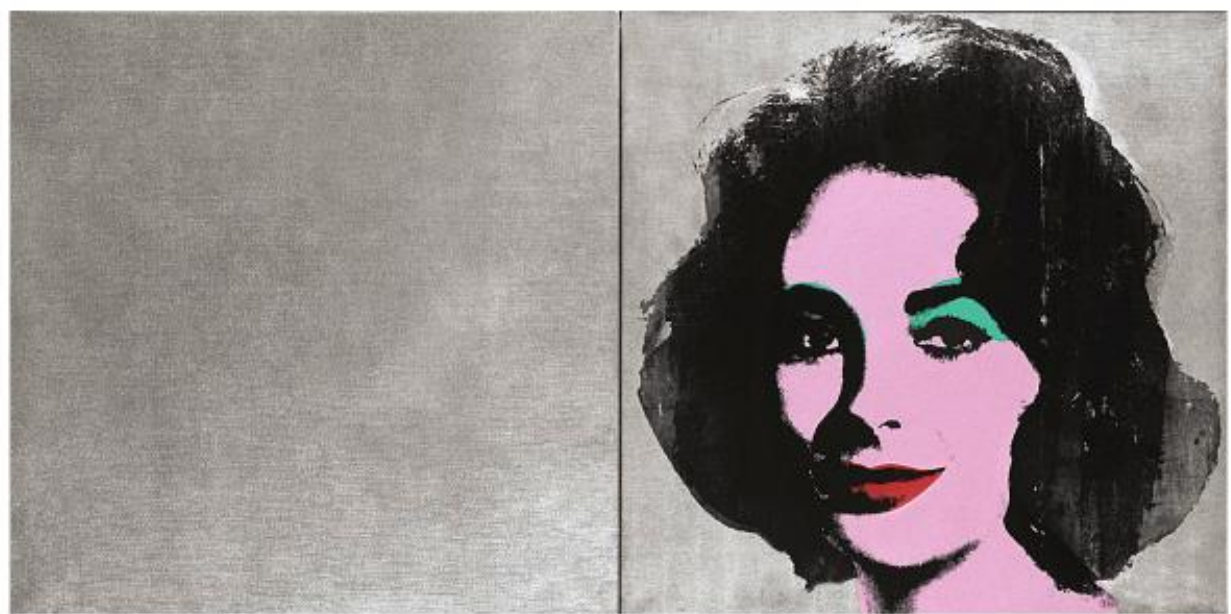

Silver Liz (1965)

$101,6 \times 203,2 \mathrm{~cm}$

Coleção privada 


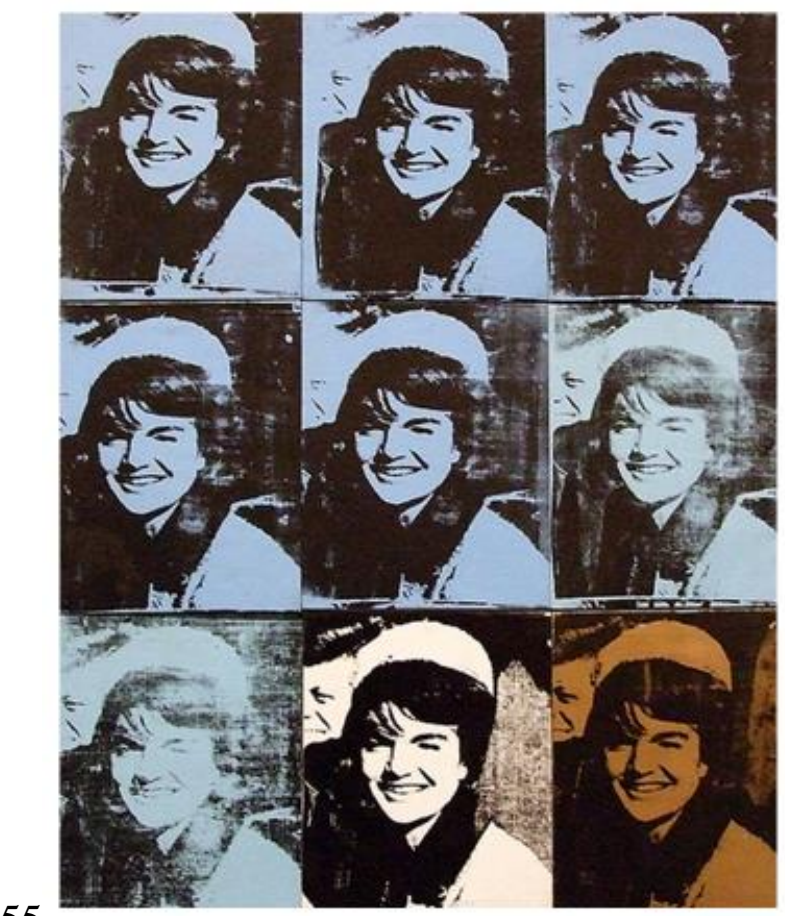

Andy Warhol (1928-1987)

Nine Jackies (1964)

Acrylic and silkscreen on canvas

(165.1 $134.6 \times 5.1 \mathrm{~cm})$

The Metropolitan Museum of Art.
Gerhard Richter (1932),

Betty (1988)

Óleo sobre tela, $102 \mathrm{~cm} \times 72 \mathrm{~cm}$

Saint Louis Art Museum, St. Louis, EEUU 

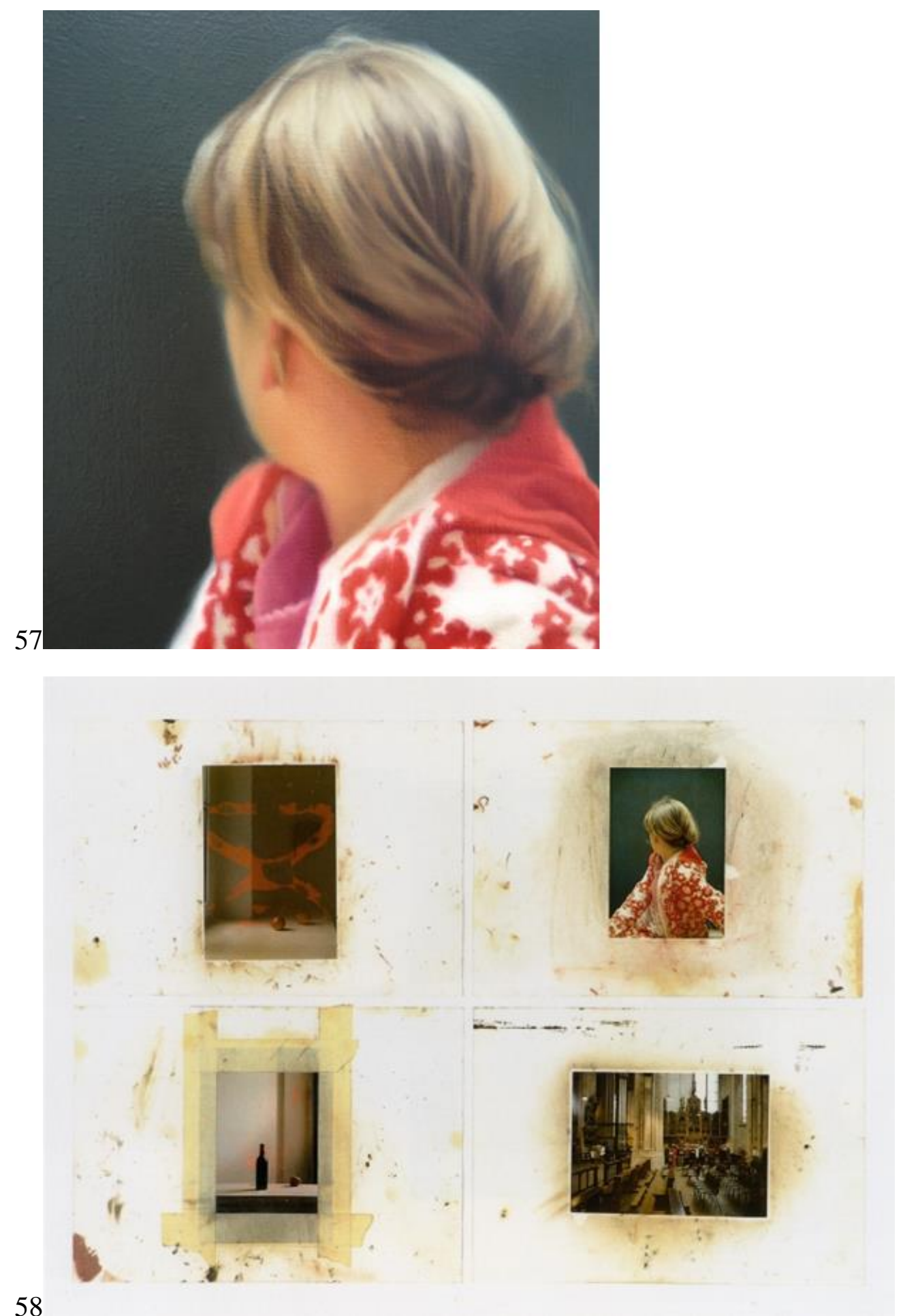


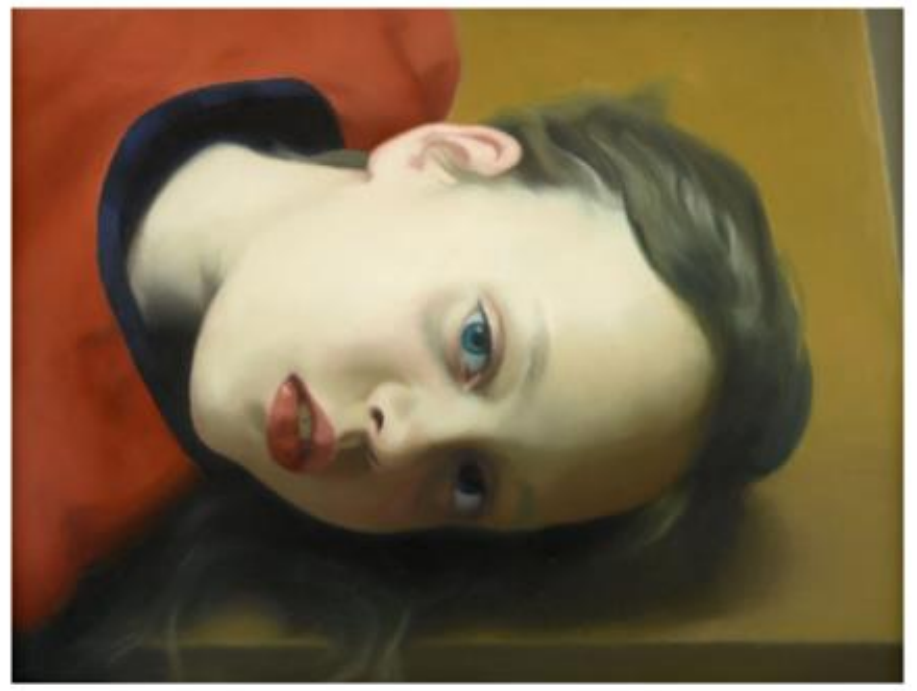

Gerhard Richter (1932): Betty, 1977

Óleo sobre tela, $30 \mathrm{~cm} \times 40 \mathrm{~cm}$

Museu Ludwig, Colônia

59

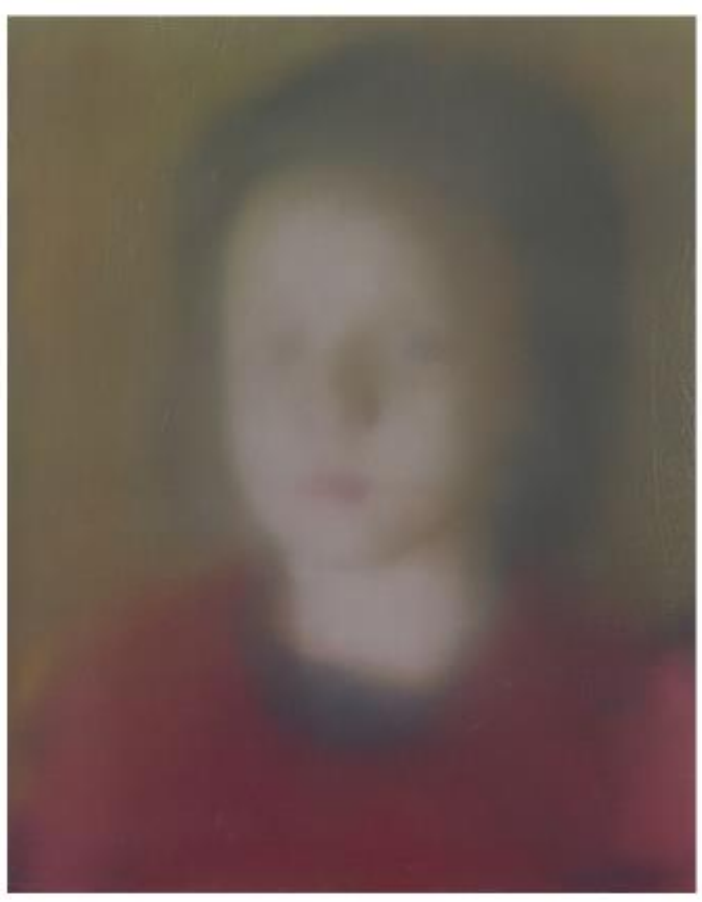

Gerhard Richter (1932):

Betty, 1977

$50 \mathrm{~cm} \times 40 \mathrm{~cm}$ óleo sobre tela

60 
61

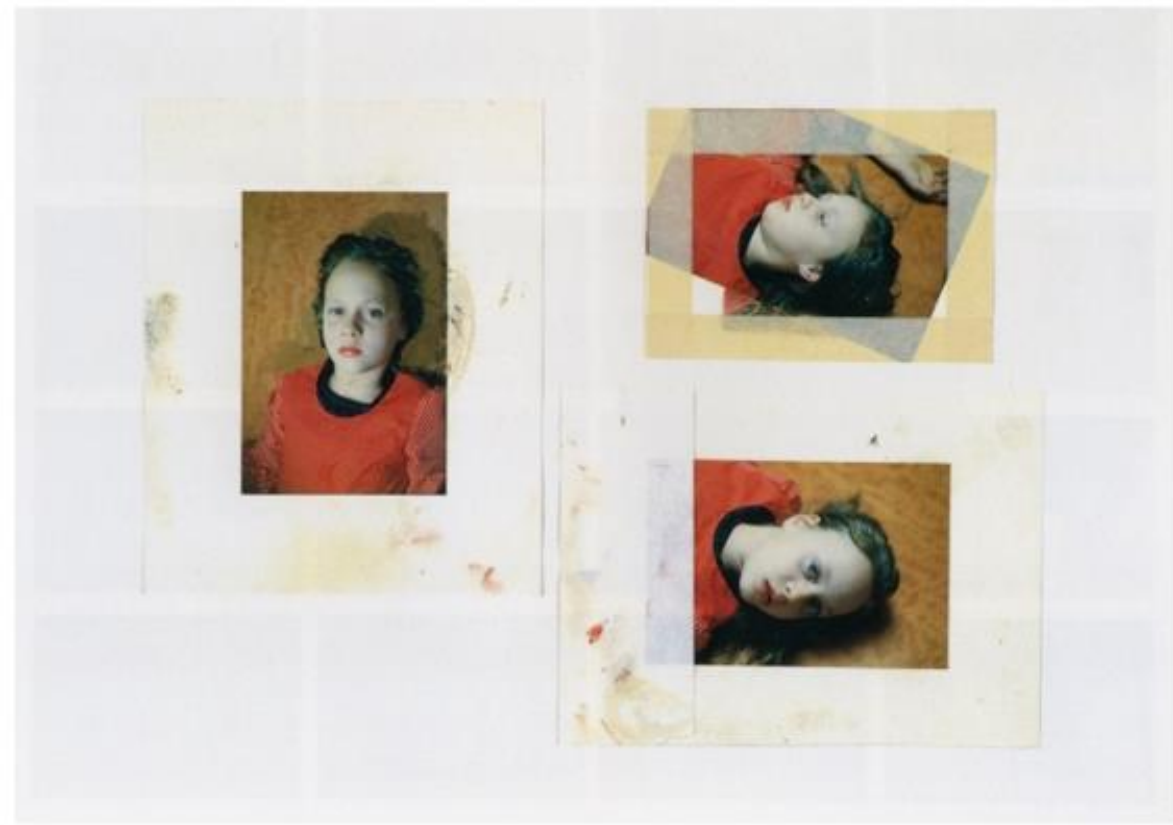

Atlas, página 394. $197836.7 \mathrm{~cm} \times 51.7 \mathrm{~cm}$

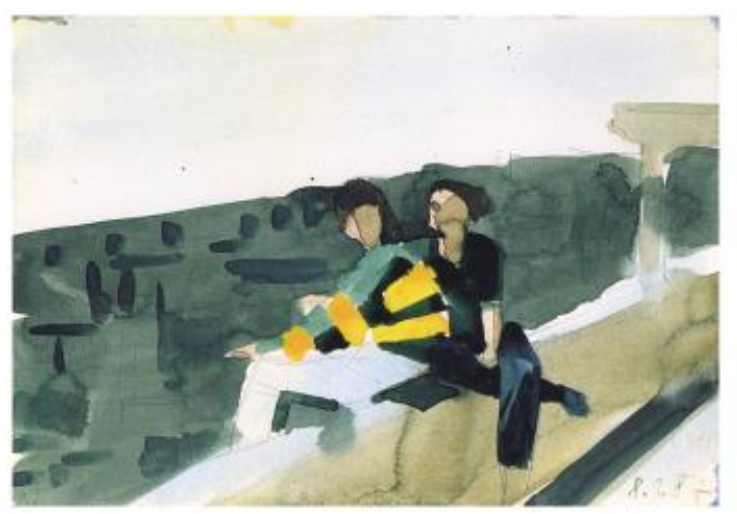

Gerhard Richter (1932): Isa e Betty, 8.1.87

$198716.5 \mathrm{~cm} \times 24 \mathrm{~cm}$

Aquarela

62 


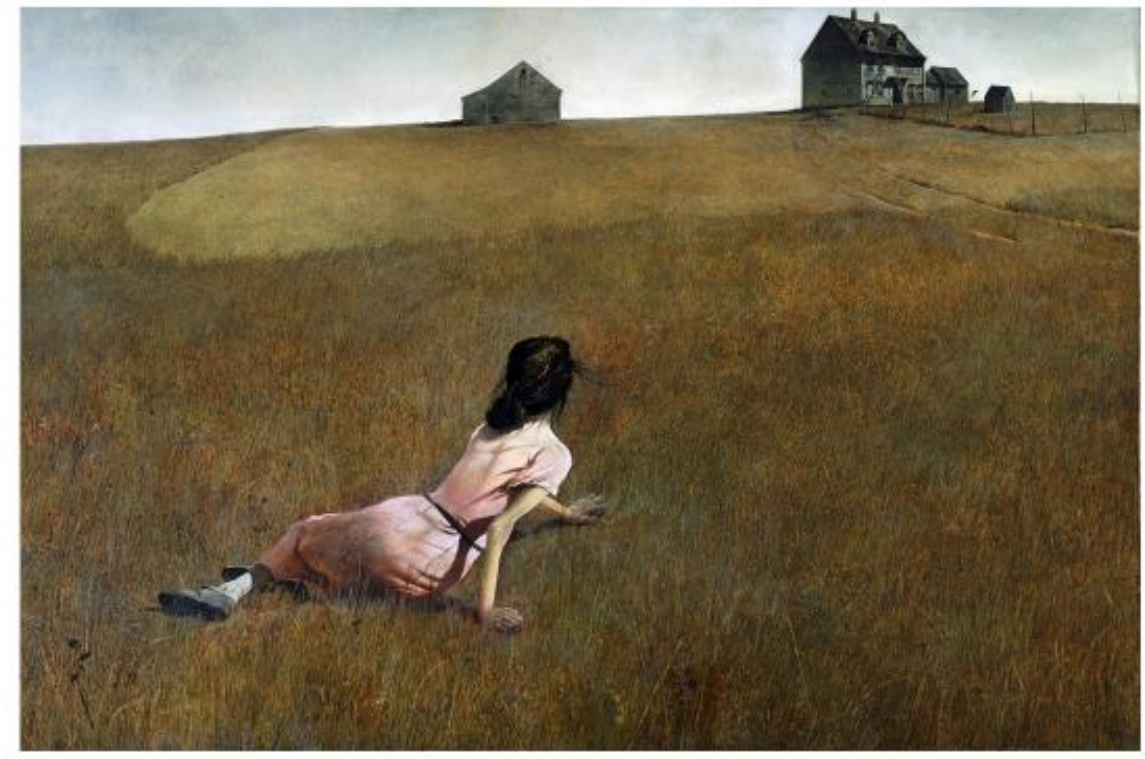

Andrew Wyeth (1917-2009): Christina's World, 1948

Tempera sobre painel, $81,9 \times 121,3 \mathrm{~cm}$

63

Moma, Nova York

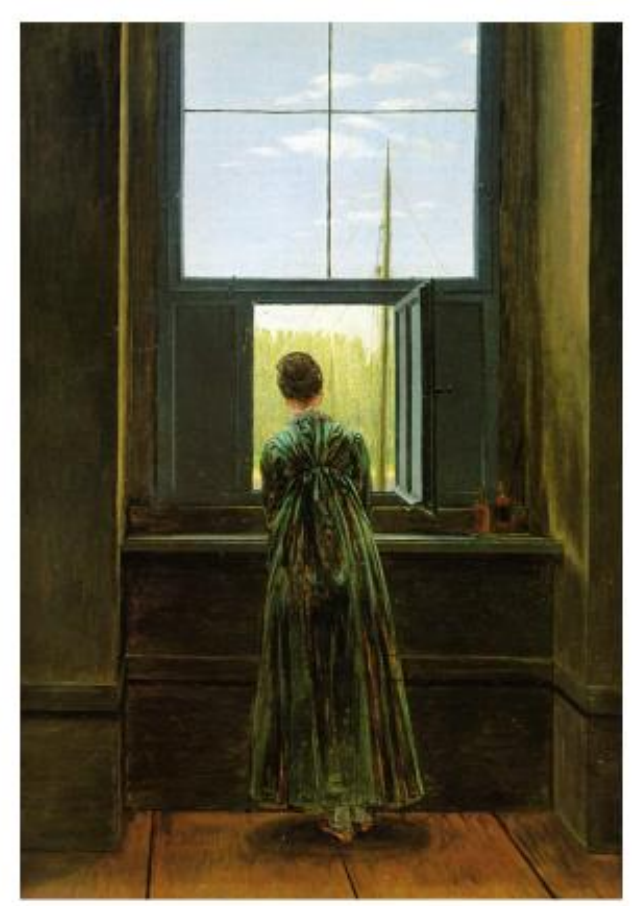

Caspar David Friedrich (1774 - 1840)

Frau am Fenster (Mulher na janela),

1818-1822

Óleo sobre tela, $44,0 \times 37,0 \mathrm{~cm}$

Alte Nationalgalerie Berlin

64 


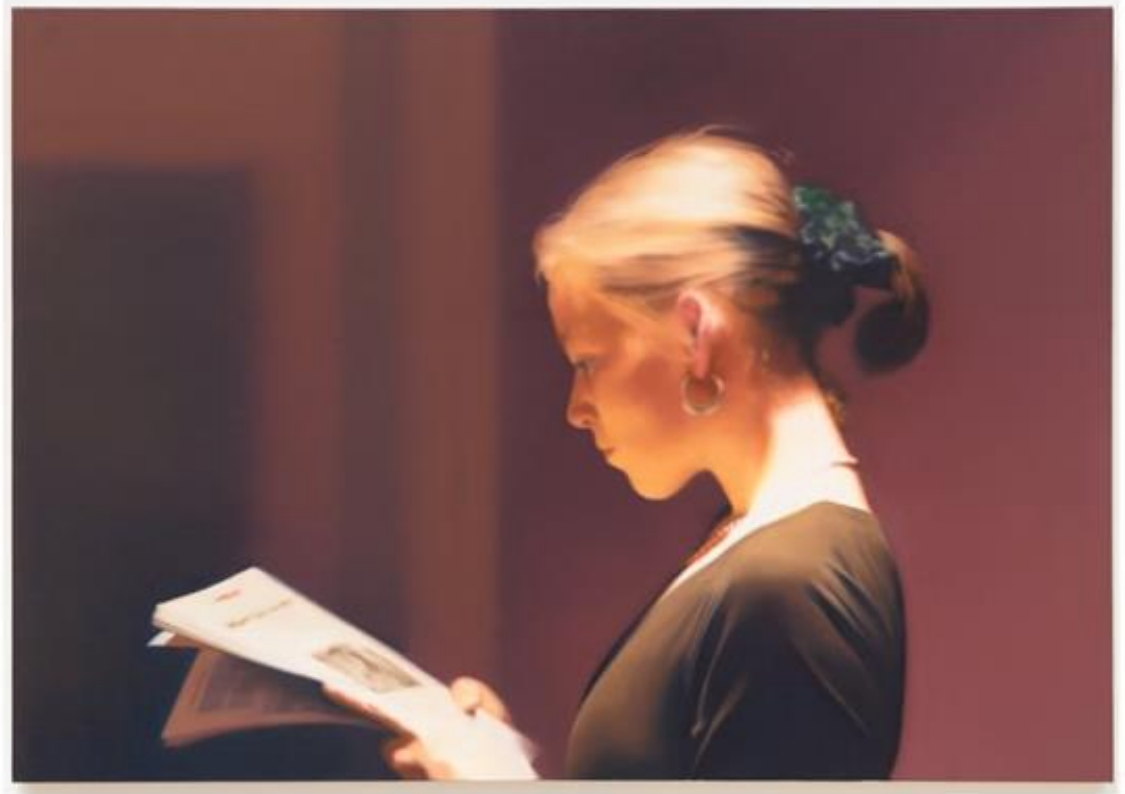

Gerhard Richter (1932), Lesende (Reader), 1994; oil on linen, $72.39 \mathrm{~cm} \times 101.92 \mathrm{~cm}$; 65 SFMOMA, San Francisco

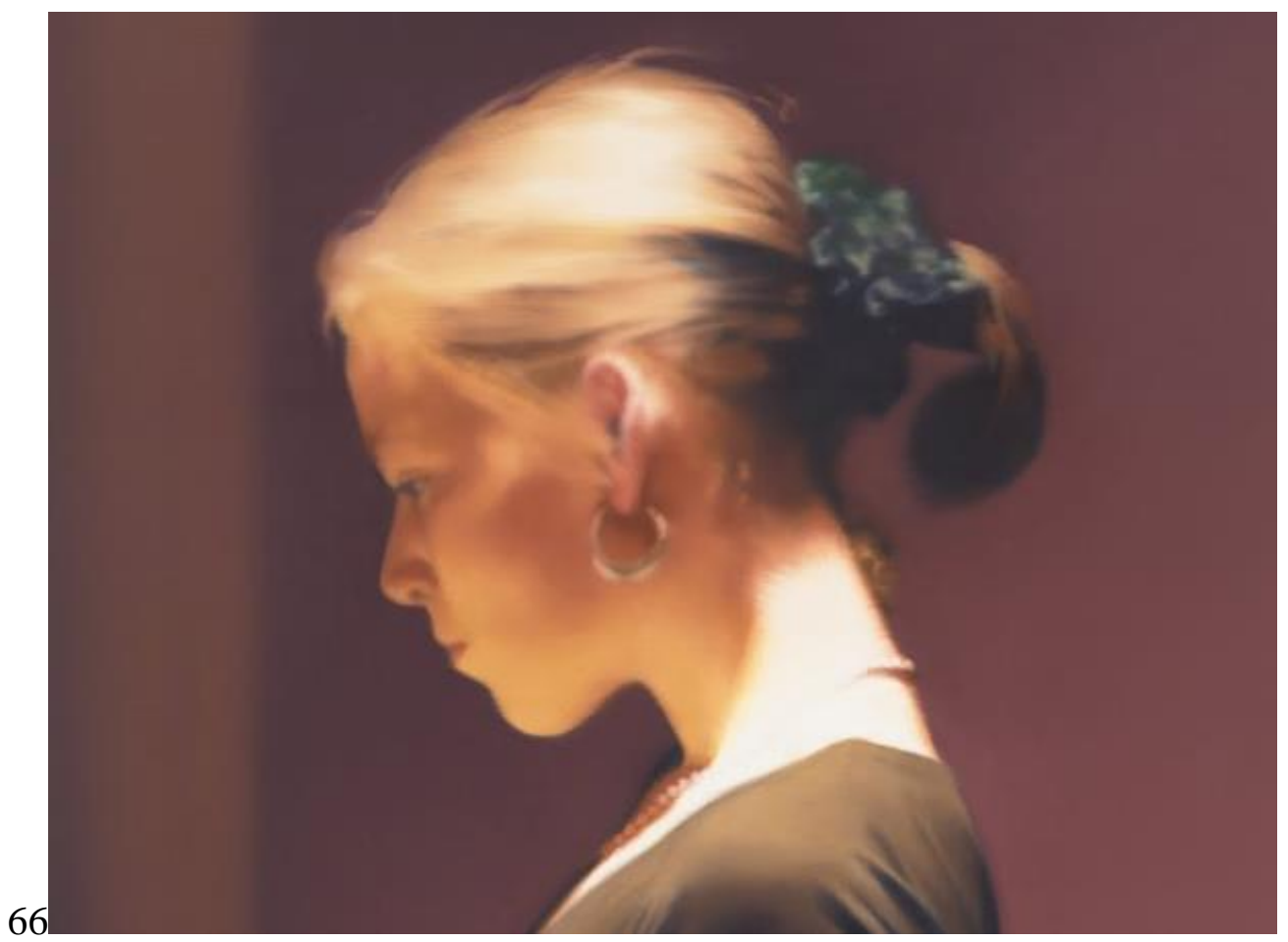




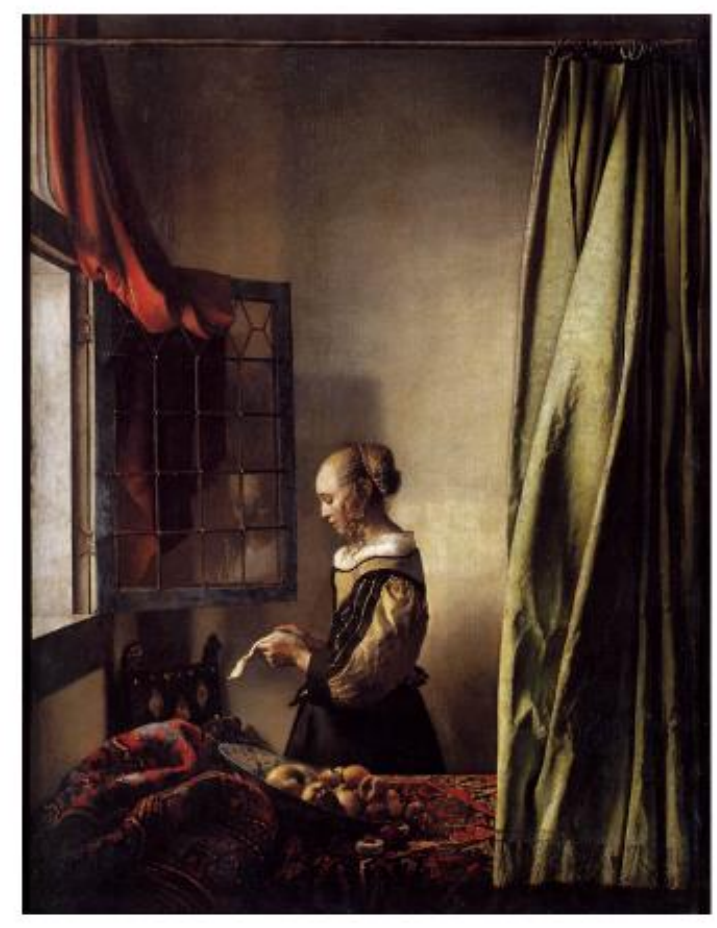

Johannes Vermeer,

Menina lê uma carta, 1657

Óleo sobre tela, $83 \times 64,5 \mathrm{~cm}$

Gemäldegalerie, Dresden

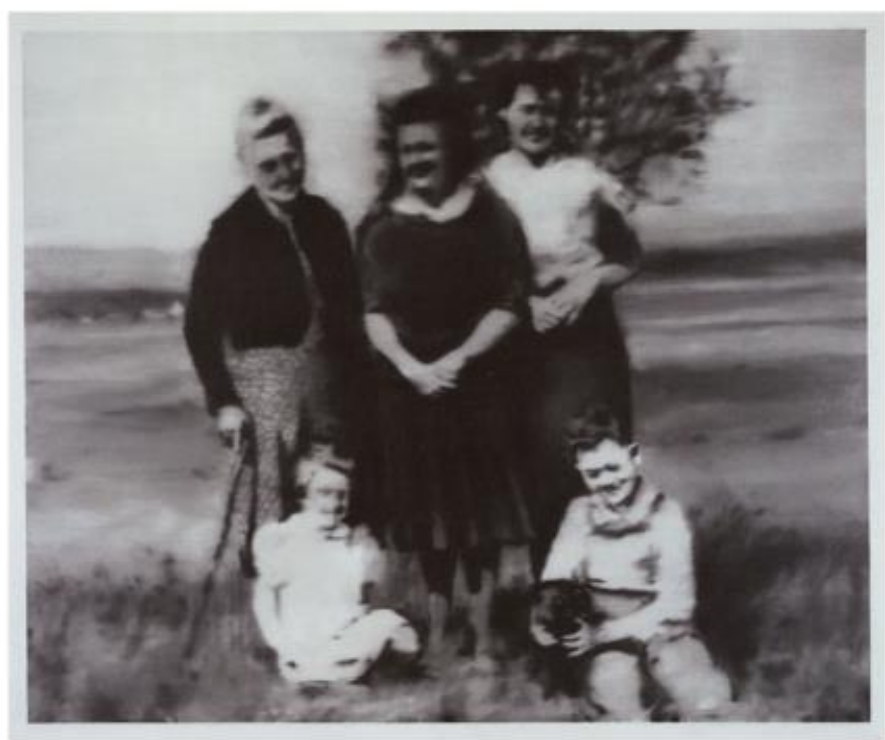

Gerhard Richter (1932): Familie (Família), 1964

Óleo sobre tela, $150 \mathrm{~cm} \times 180 \mathrm{~cm}$ Catalogue Raisonné: 30

Da esquerda para a direita: a avó de Richter Dora Schönfelder, sua irmã Gisela, Gretel Weber 68

(amiga de sua mãe), sua mãe Hildegard e Richter com seu cão Struppi. 


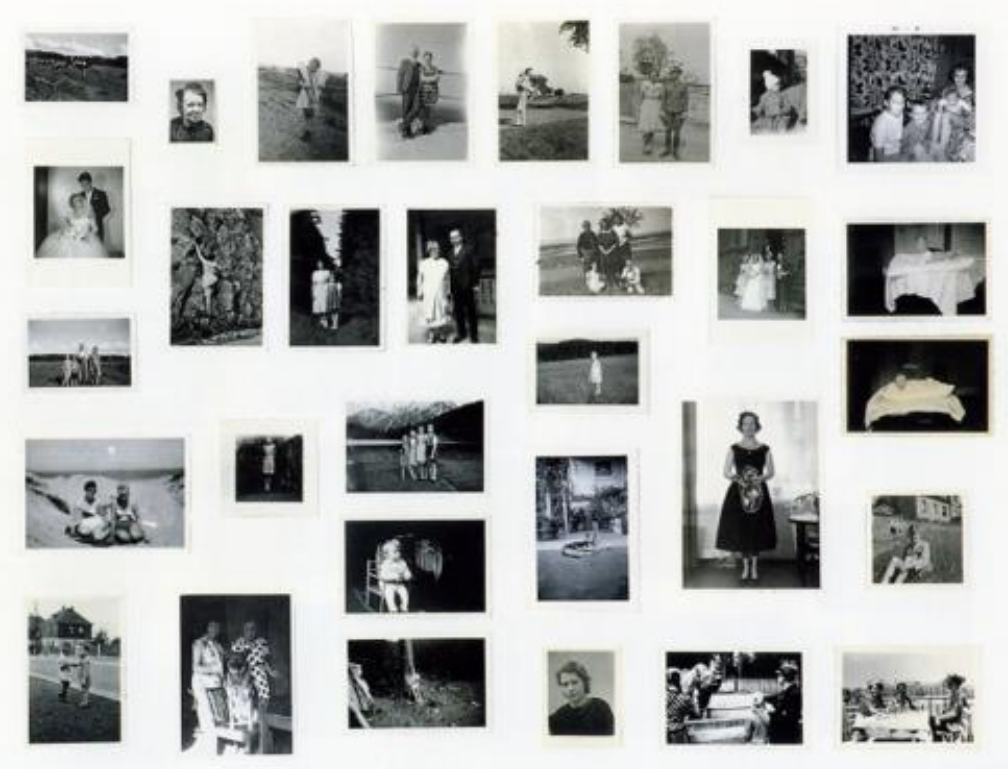

Folha do Atlas: 3,1962

$51,7 \mathrm{~cm} \times 66,7 \mathrm{~cm}$

69

Städtische Galerie im Lenbachhaus und Kunstbau München, Munique

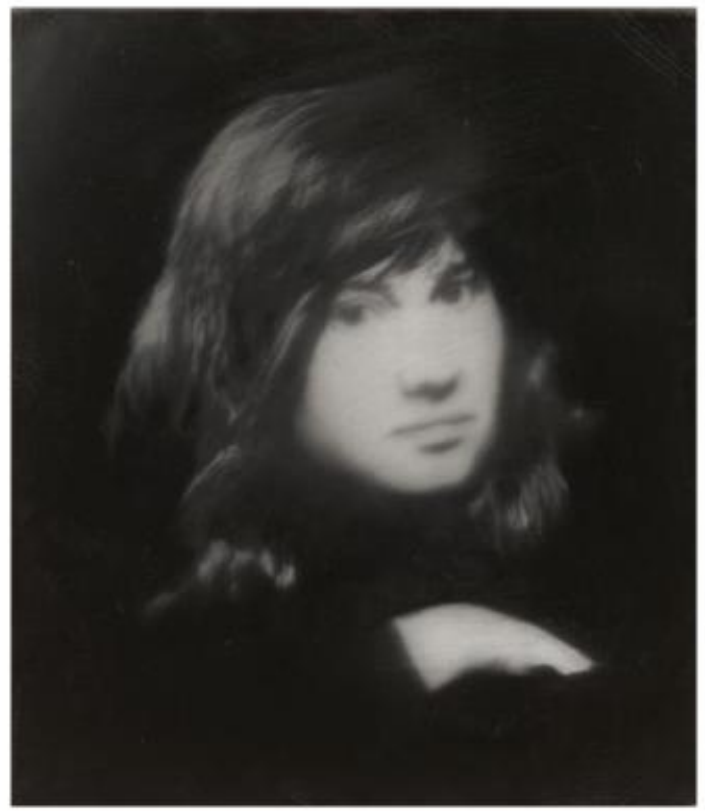

Gerhard Richter (1932):

Jugendbildnis (Youth Portrait), 1988

Oil on canvas, $67 \mathrm{~cm} \times 62 \mathrm{~cm}$

The Museum of Modern Art (MoMA),

70 New York, USA 


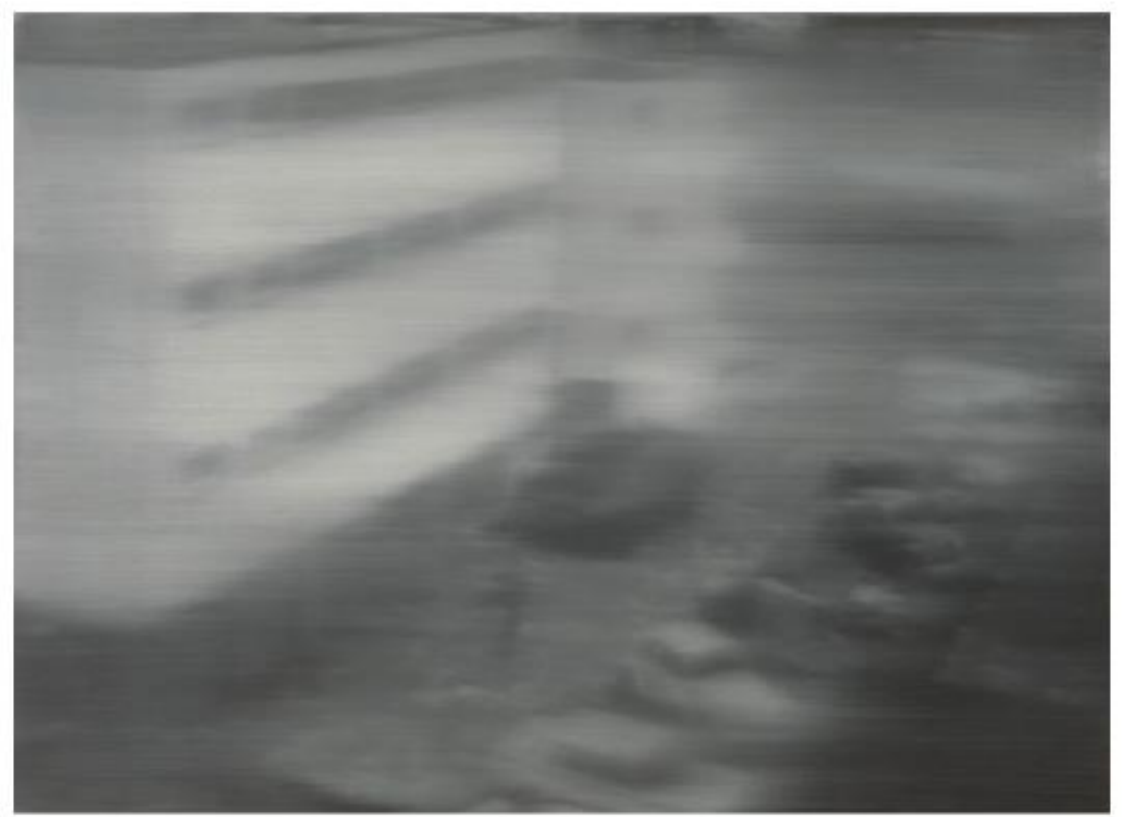

Gerhard Richter (1932): Festnahme 1(prisão 1), 1988

71

Óleo sobre tela, $92 \mathrm{~cm} \times 126,5 \mathrm{~cm}$ Moma

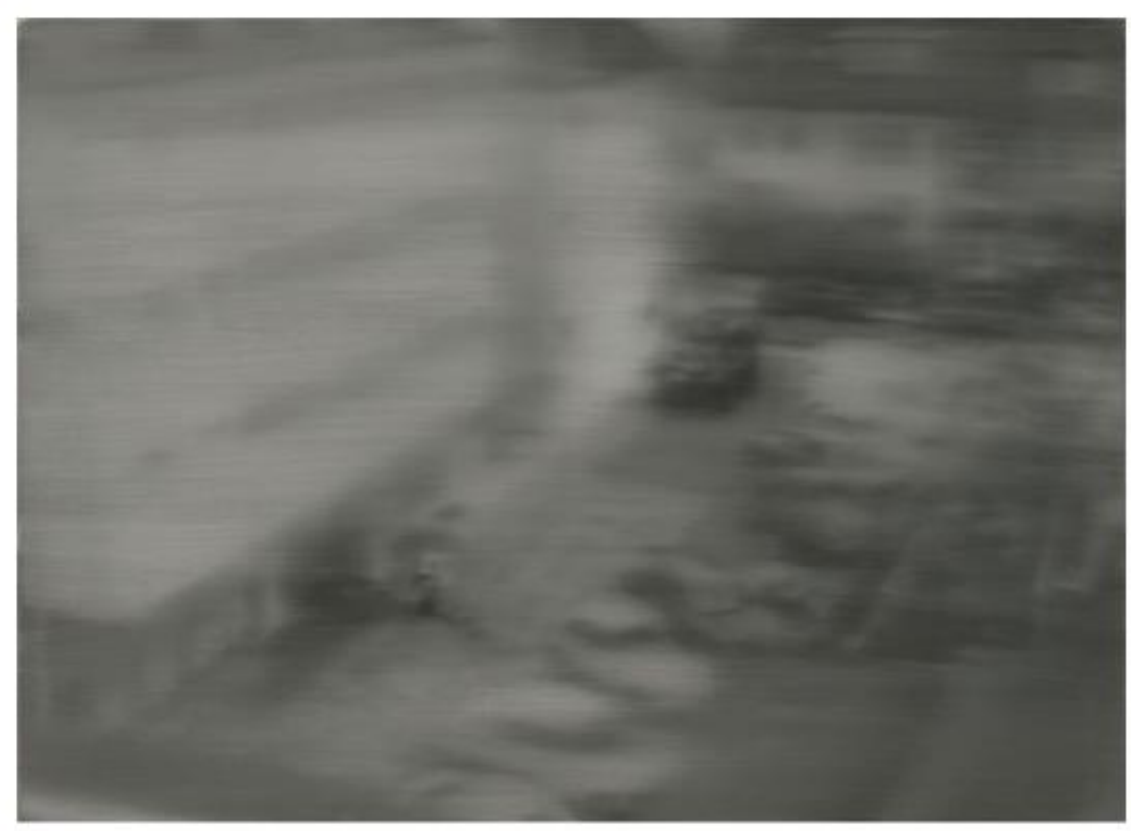

Gerhard Richter (1932): Festnahme 2 (Arrest 2), 1988

Oil on canvas, $92 \times 126 \mathrm{~cm}$. The Museum of Modern Art (MoMA), New York, USA

72 


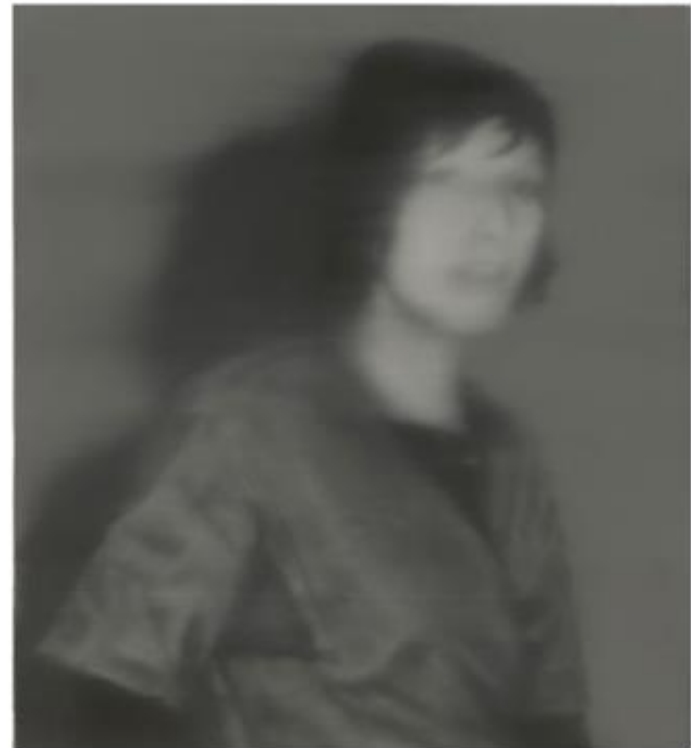

Gerhard Richter (1932):

Gegenüberstellung 1

(Confrontation 1), 1988

Oil on canvas, $112 \times 102 \mathrm{~cm}$

The Museum of Modern Art (MoMA), New York, USA

(Gundrun Enslin)

73

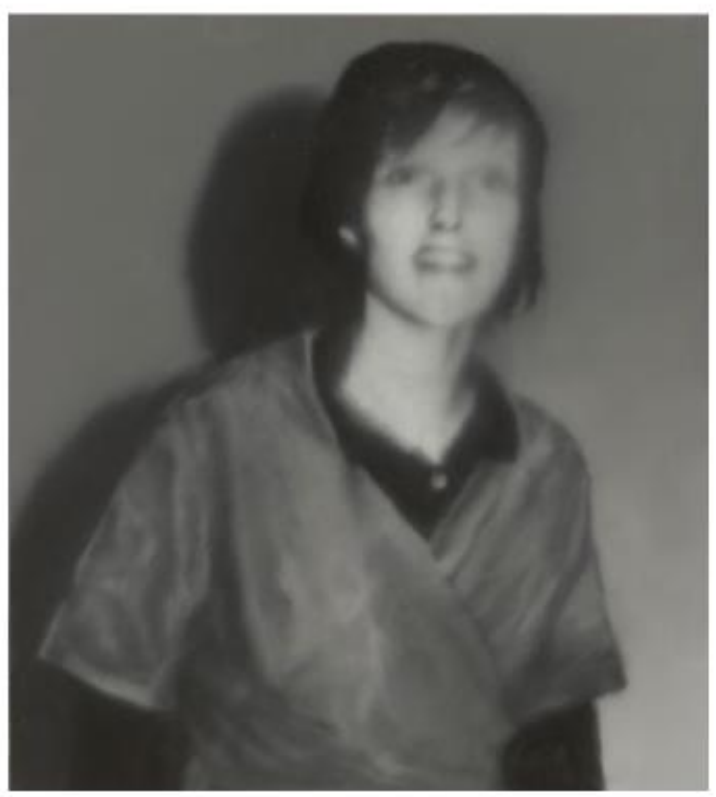

Gerhard Richter (1932):

Gegenüberstellung 2

(Confrontation 2), 1988

Oil on canvas, $112 \times 102 \mathrm{~cm}$

The Museum of Modern Art (MoMA), New York, USA

74 


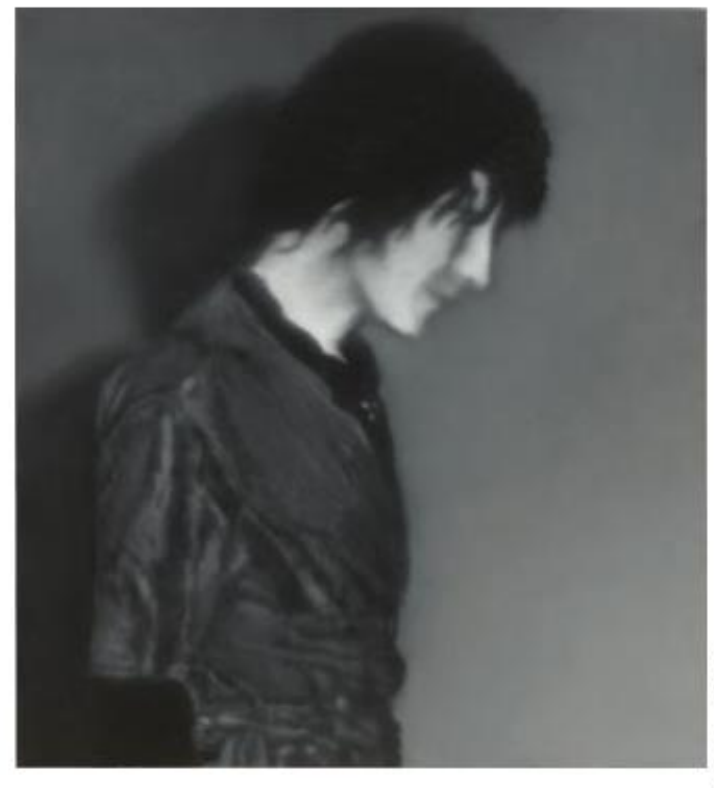

Gerhard Richter (1932):

Gegenüberstellung 3

(Confrontation 3), 1988

Oil on canvas, $112 \times 102 \mathrm{~cm}$

The Museum of Modern Art (MoMA), New York, USA

75

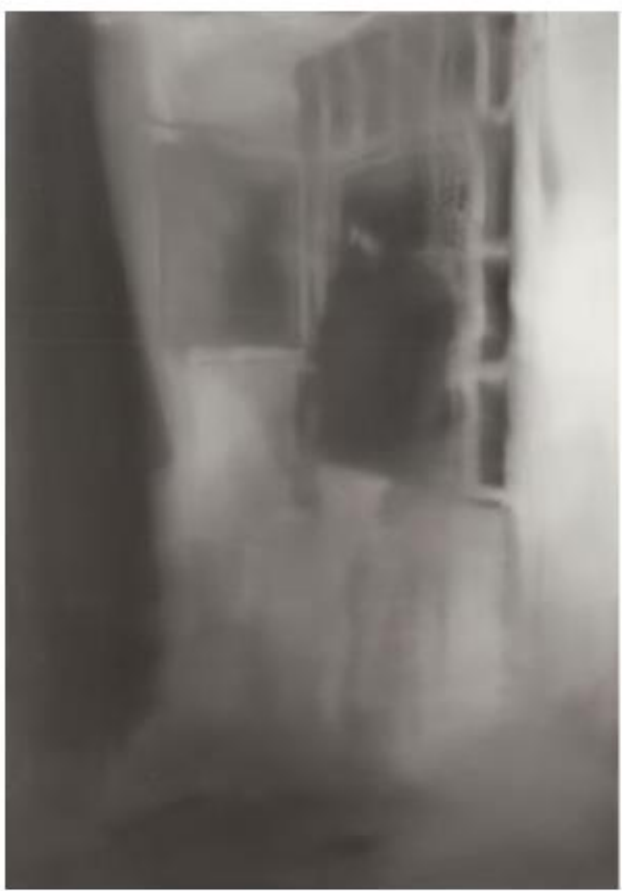

Gerhard Richter (1932):

Erhängte

(Hanged), 1988

Oil on canvas, $200 \times 140 \mathrm{~cm}$

The Museum of Modern Art (MoMA),

New York, USA

(Gundrun Enslin)

76 


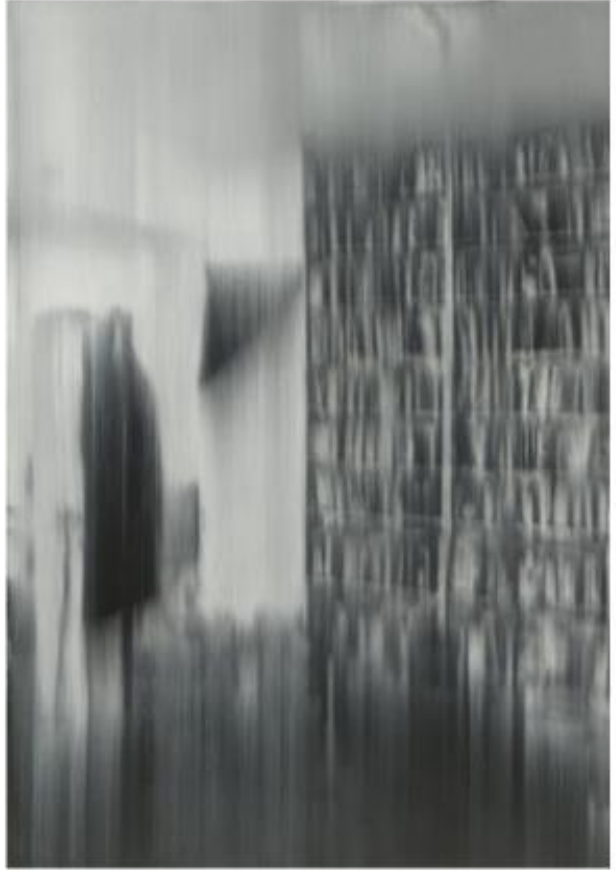

Gerhard Richter (1932):

Zelle (Cell), 1988

Oil on canvas, $200 \times 140 \mathrm{~cm}$

The Museum of Modern Art

(MoMA), New York, USA

77

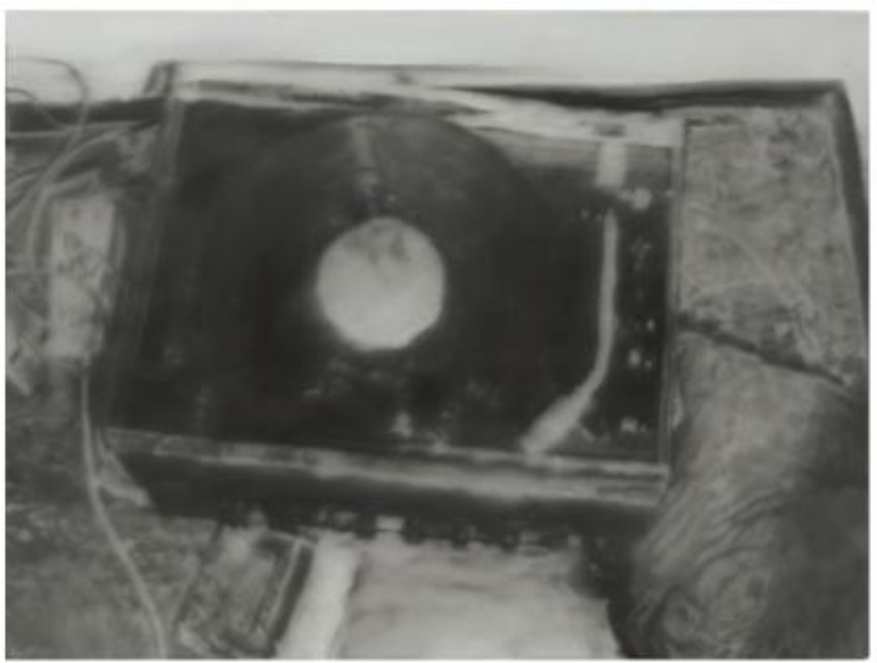

Plattenspieler, 1988

$62 \mathrm{~cm} \times 83 \mathrm{~cm}$

78 


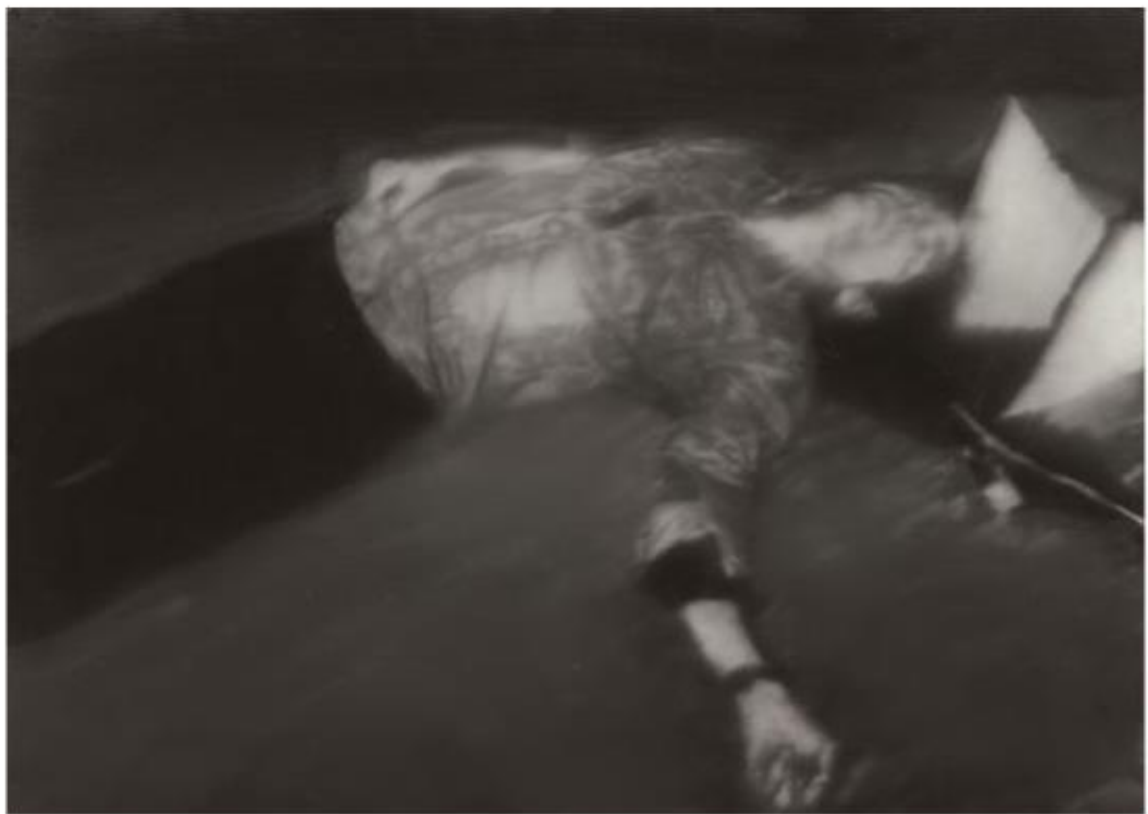

Erschossener 1 (Man Shot Down 1) (Andreas Baader), 1988

Oil on canvas, $100 \mathrm{~cm} \times 140 \mathrm{~cm} \quad$ Moma

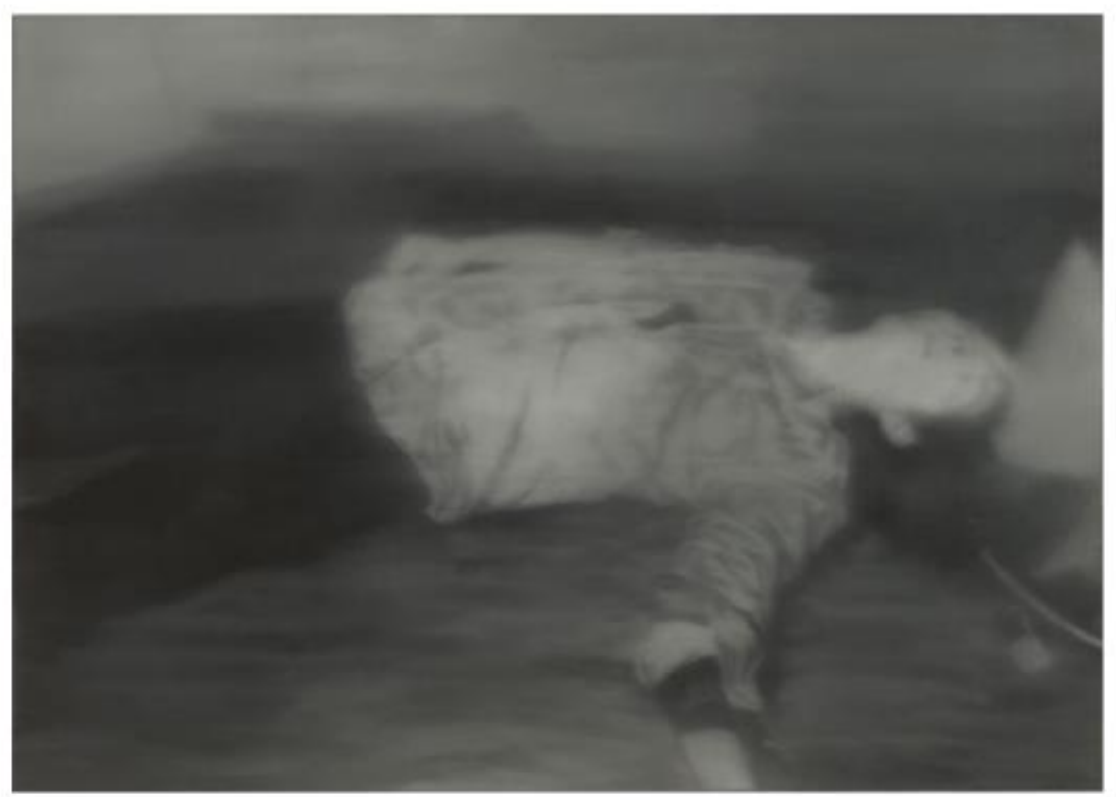

Erschossener 2 (Man Shot Down 2) (Andreas Baader), 1988 Oil on canvas, $100 \mathrm{~cm} \times 140 \mathrm{~cm}$

80 Moma 


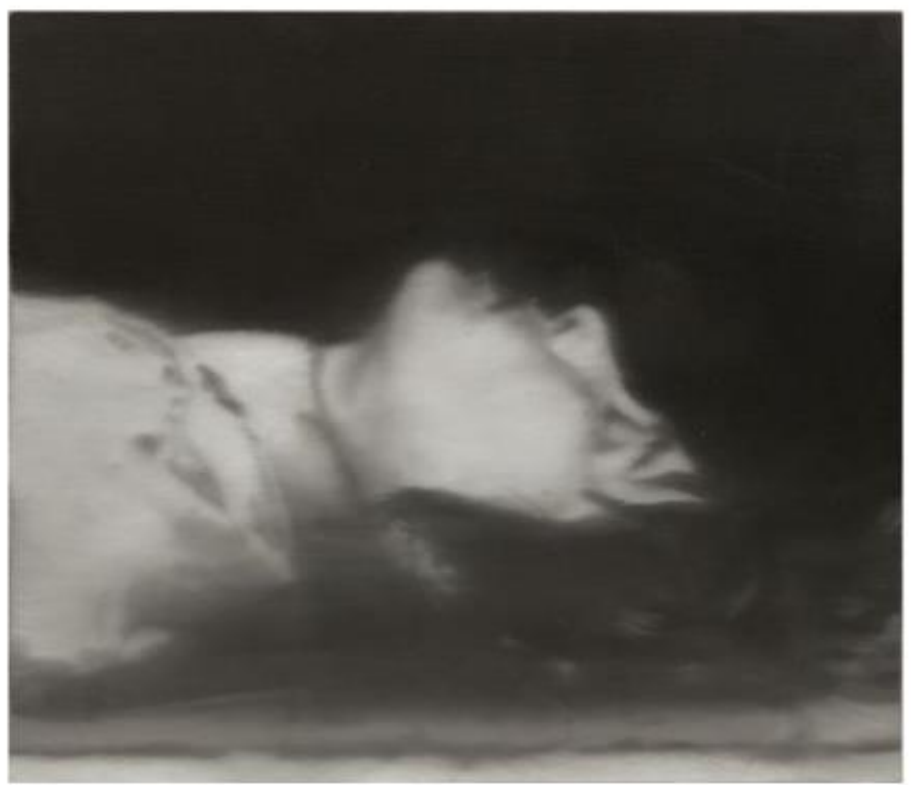

Gerhard Richter (1932): Série Baader Meinhoff: Tote (morte) 1988 $62 \mathrm{~cm} \times 73 \mathrm{~cm}$

81

Oil on canvas The Museum of Modern Art (MOMA), New York, USA

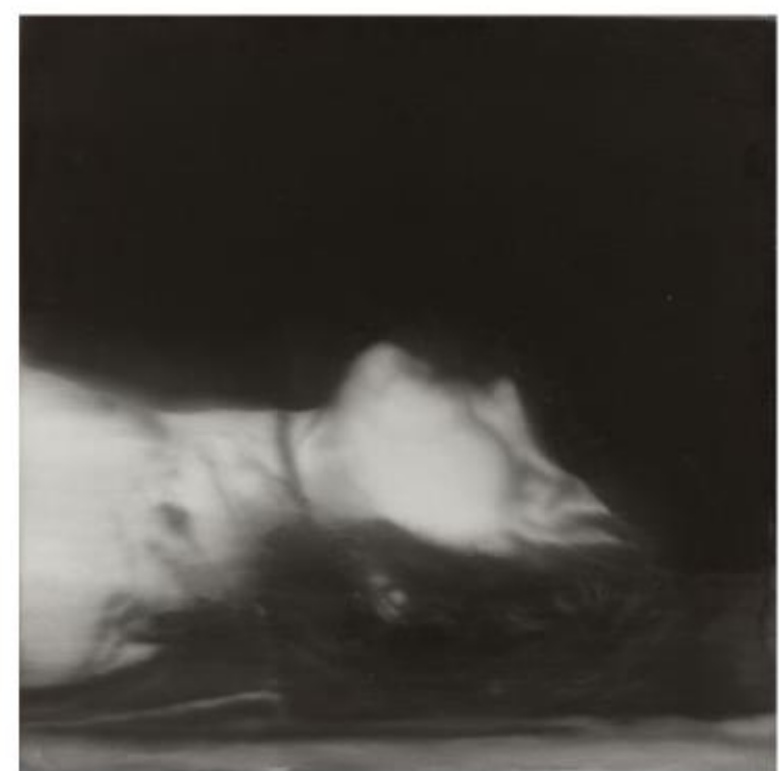

Gerhard Richter (1932): Série Baader Meinhoff: Tote (morte) 1988 , óleo sobre tela, $62 \times 62 \mathrm{~cm}$

82

The Museum of Modern Art, NY 


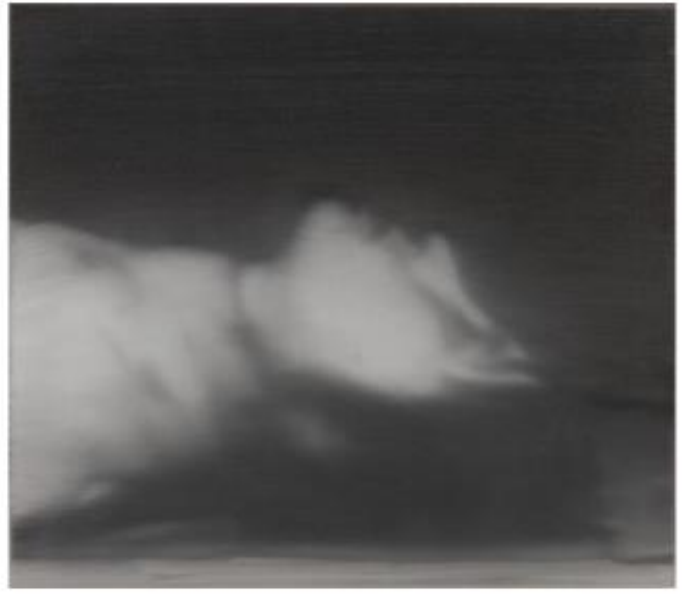

Gerhard Richter (1932): Série Baader

Meinhoff: Tote (morte) 1988

$35 \times 40 \mathrm{~cm}$

Oil on canvas The Museum of Modern Art

83

(MoMA), New York, USA

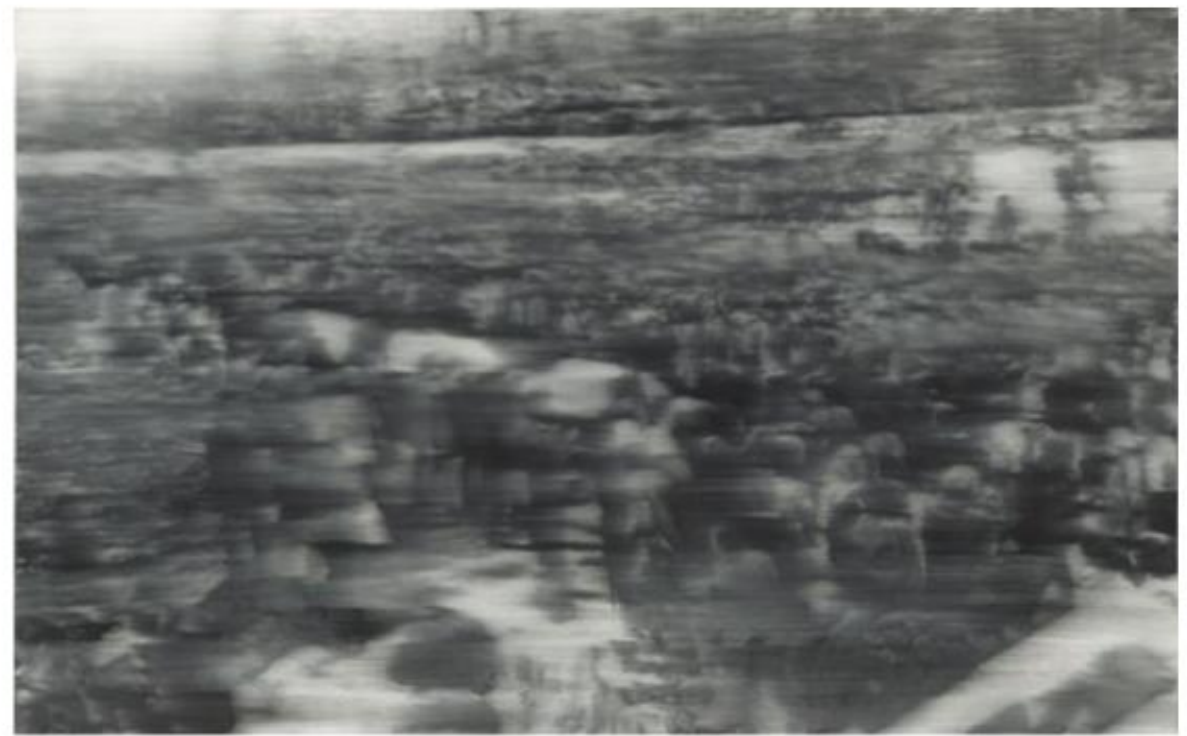

Gerhard Richter: Série Baader Meinhoff: Funeral 1988

Óleo sobre tela, $200 \mathrm{~cm} \times 320 \mathrm{~cm}$

84

Museum of Modern Art (MoMA), New York, USA 


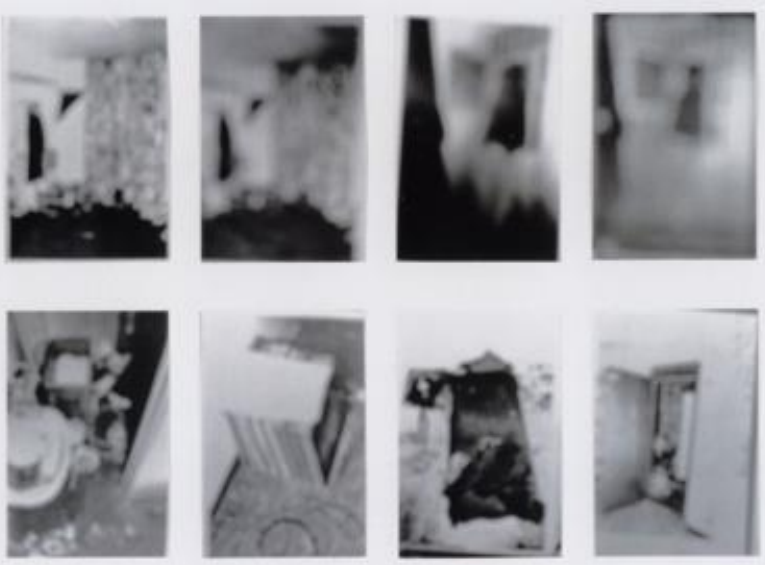

85

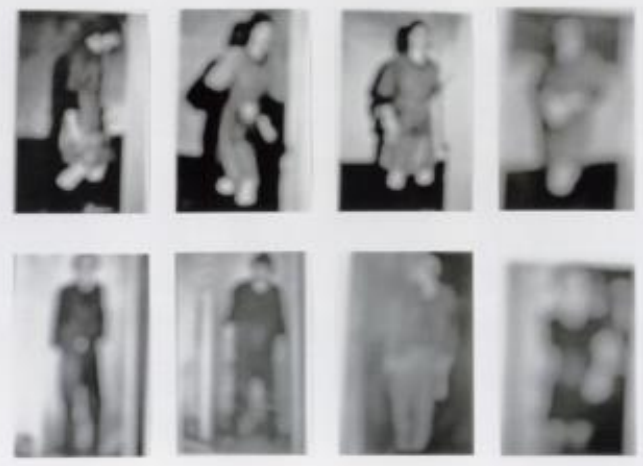

86 

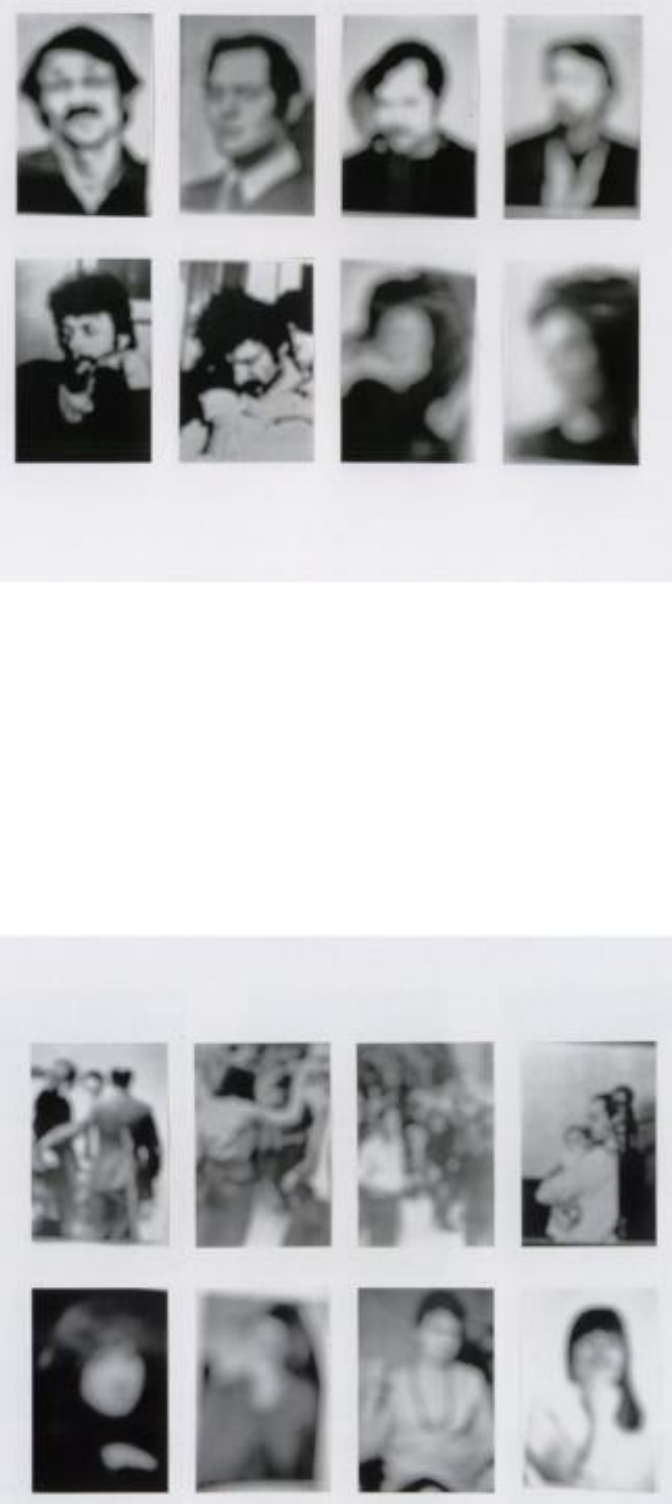

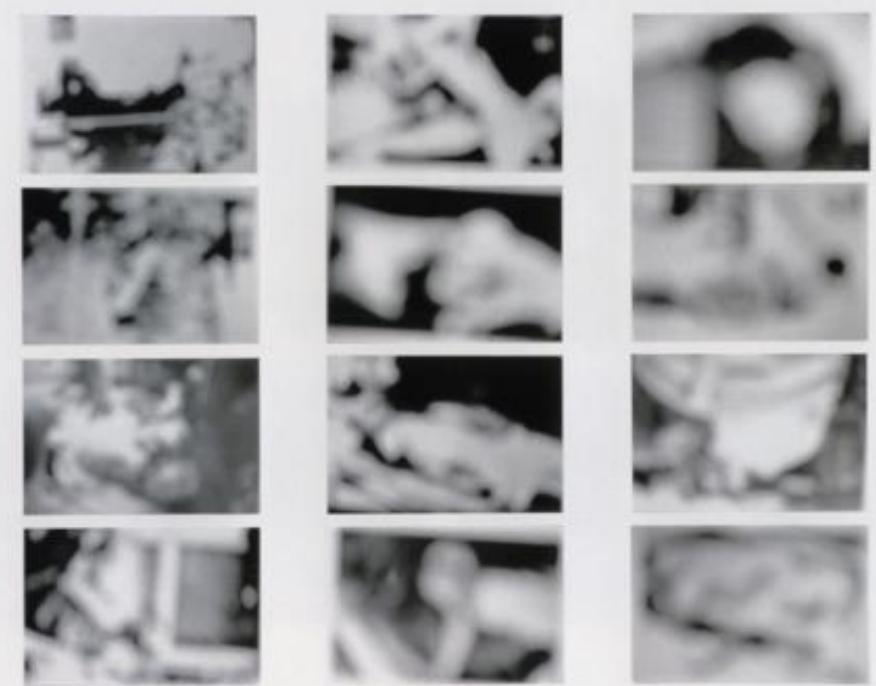

89

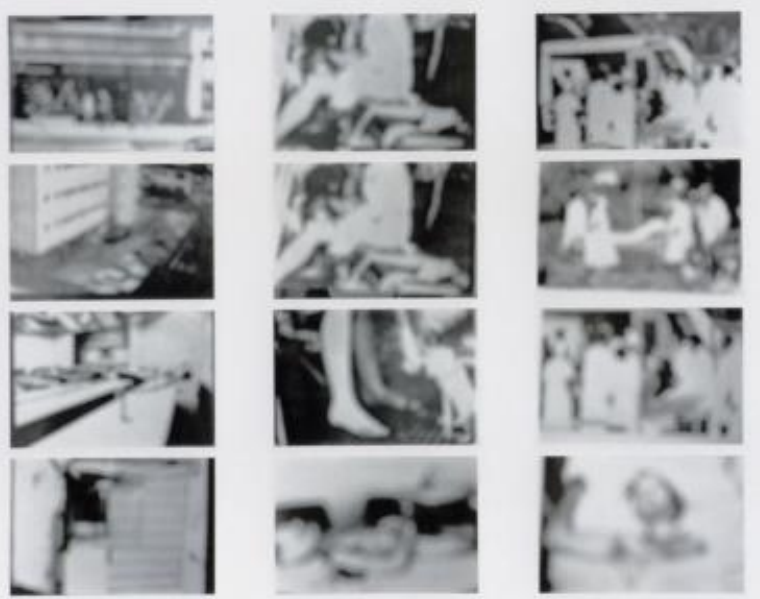

90 


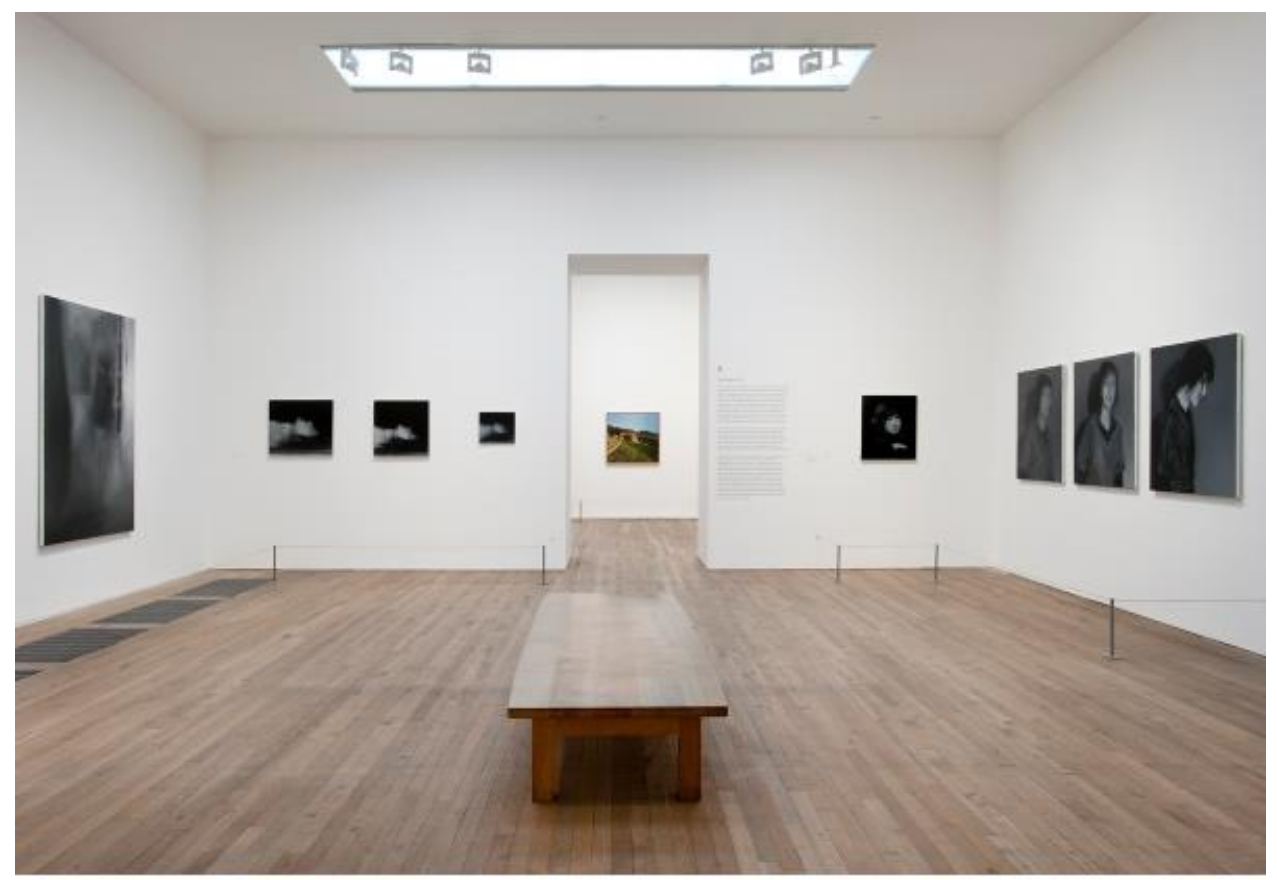

91

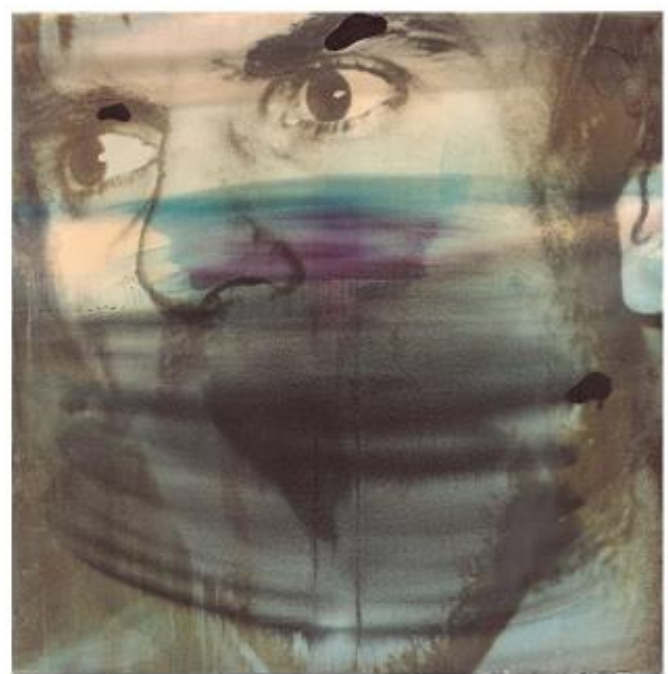

Wolf Vostell,

Dutschke, 1968,

foto impressa na lona, esmalte, acrílico. $101 \times 103 \mathrm{~cm}$

Stiftung Haus der Geschichte der

Bundesrepublik Deutschland,

Bonn 


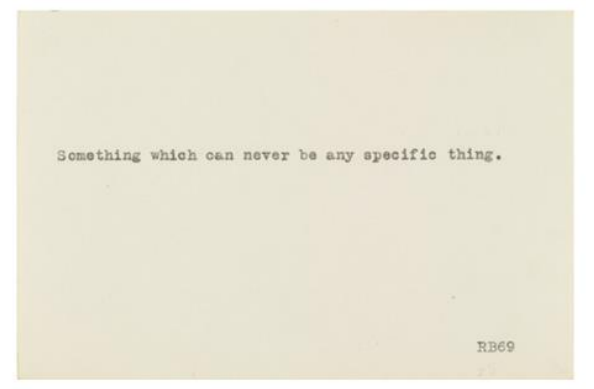

Robert Barry (1936)

93

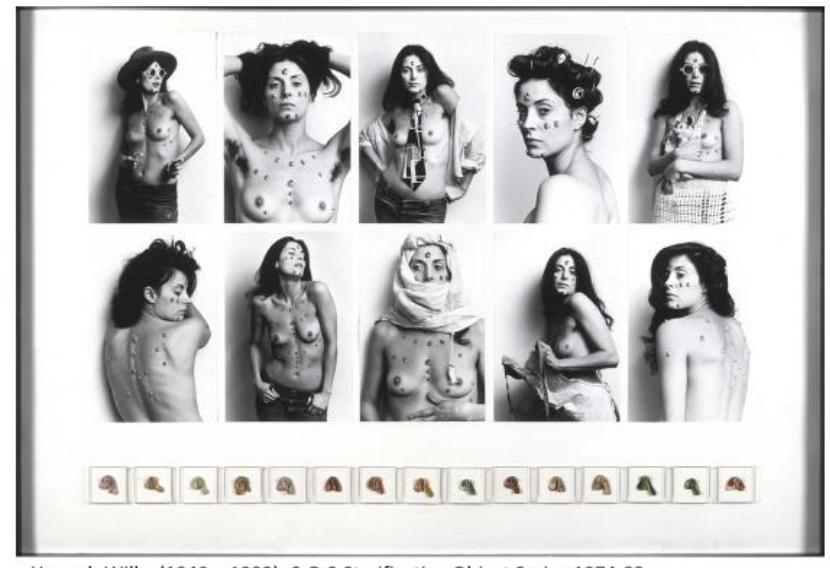

Hannah Wilke (1940 - 1993): S.O.S.Starification Object Series,1974-82

Emulsão a prata com esculturas de goma de mascar, 101,6 × 148,6 ×5,7 cm

94

Museum of Modern Art, NY

95

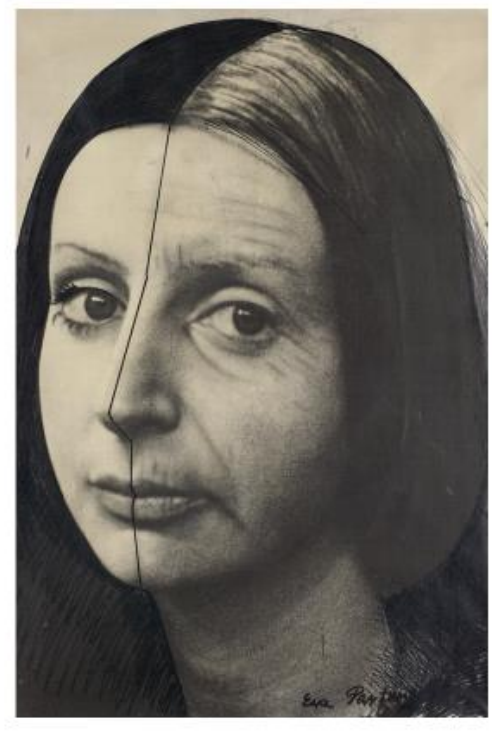

Ewa Partum

Change, 1974 


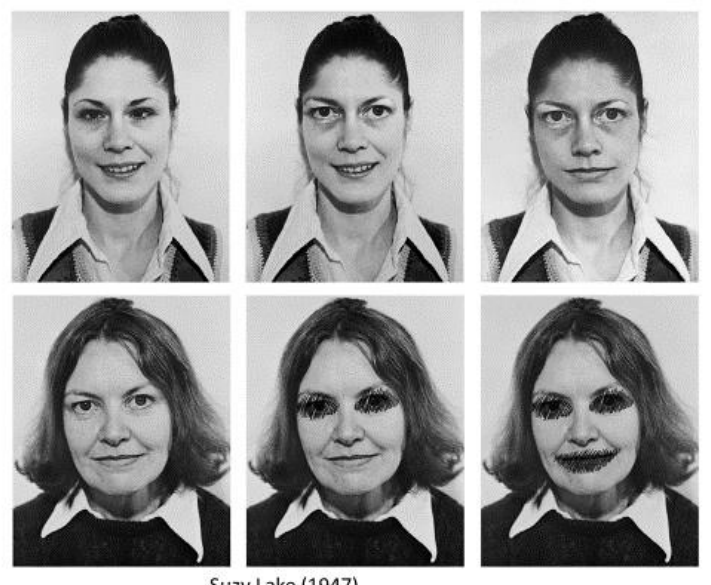

96 Transformations, 1973

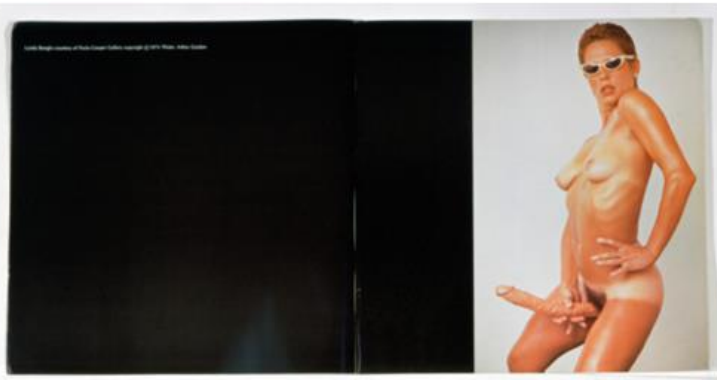

Lynda Benglis, "Advertisement in 'Artforum,'" 1974. A

97

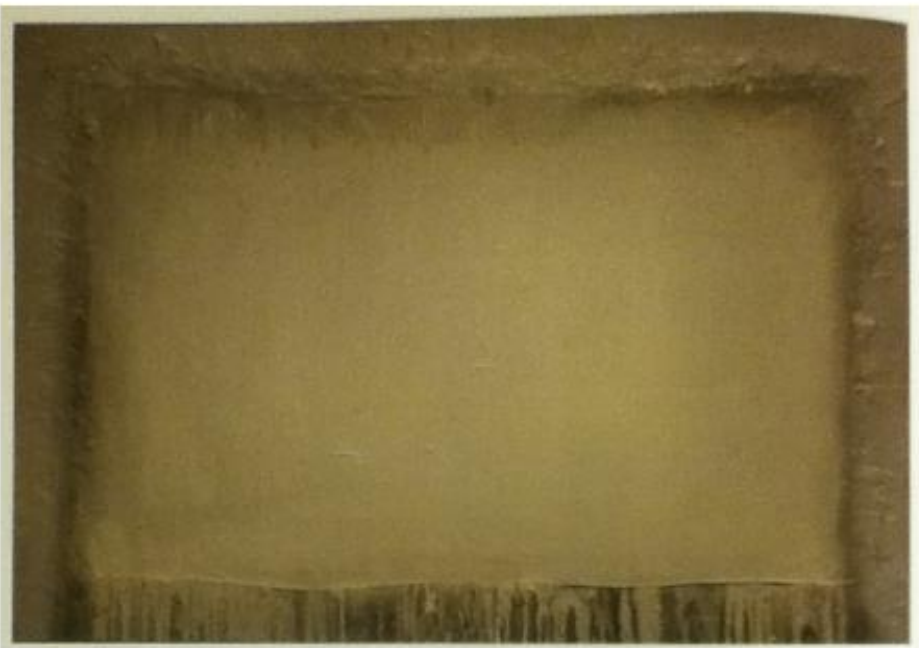




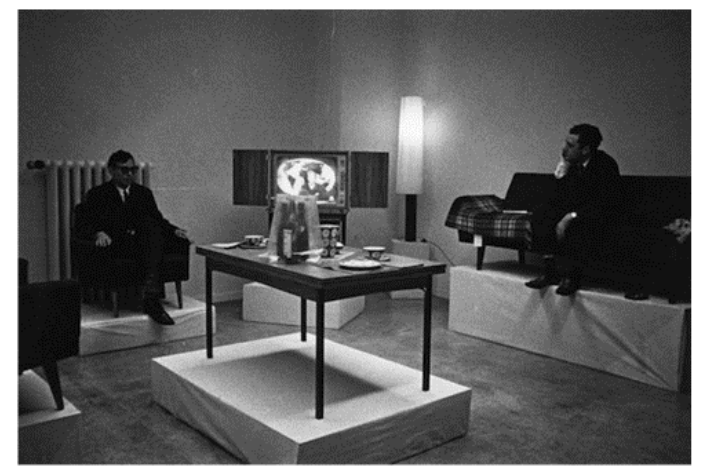

Leben mit Pop - Eine Demonstração für den kapitalistischen Realismus de 1963

(Viver com a Pop - uma demonstração do Realismo Capitalista)
11 de outubro de 1963, Konrad Lueg e Gerhard Richter na loja de móveis Berges, em Düsseldorf. 99 Foto: Reiner Ruthenbeck

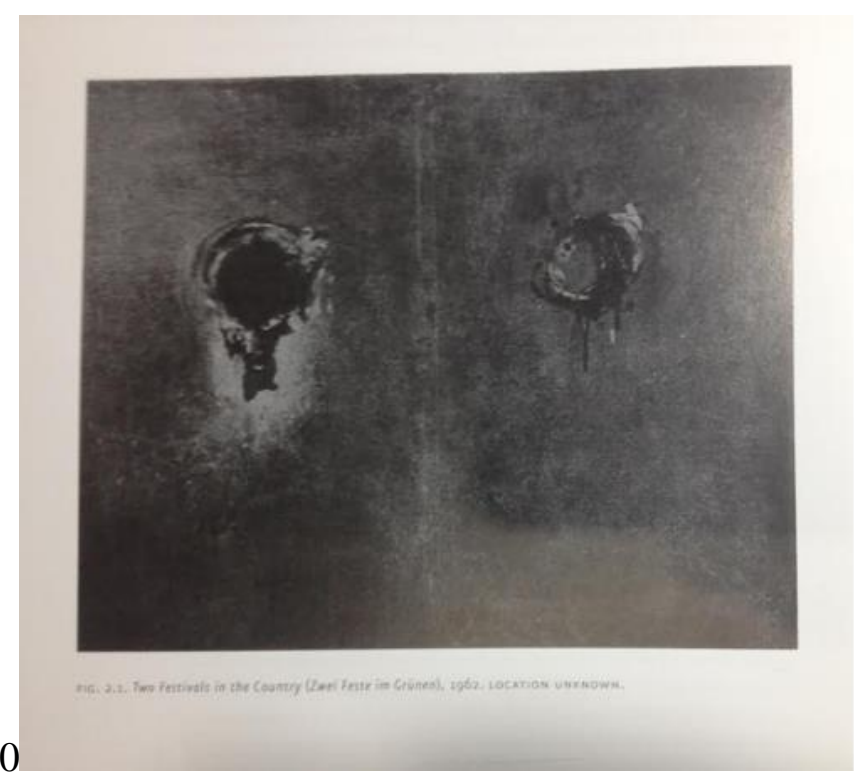

100

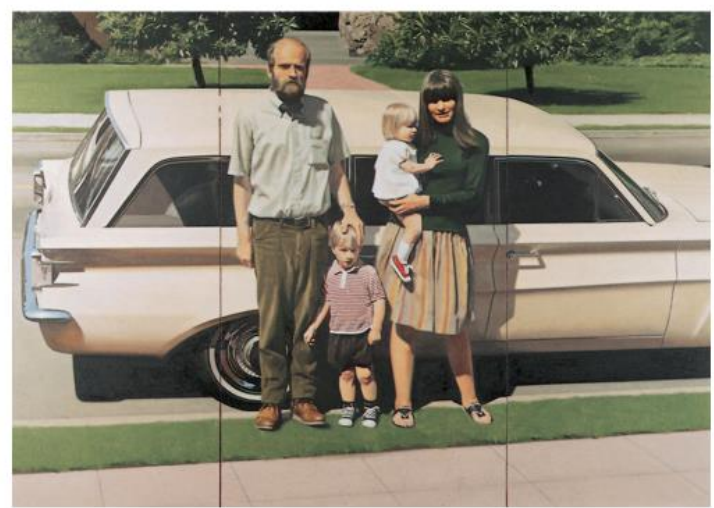

Robert Bechtle (1932): '61 Pontiac, 1968-1969.

Óleo sobre tela, $151,8 \times 214 \mathrm{~cm}$

101 Whitney Museum of American Art, New York; 


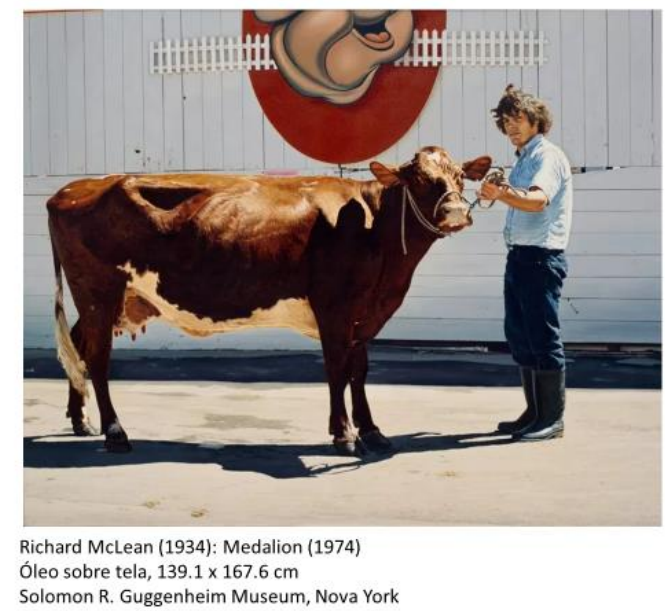

102

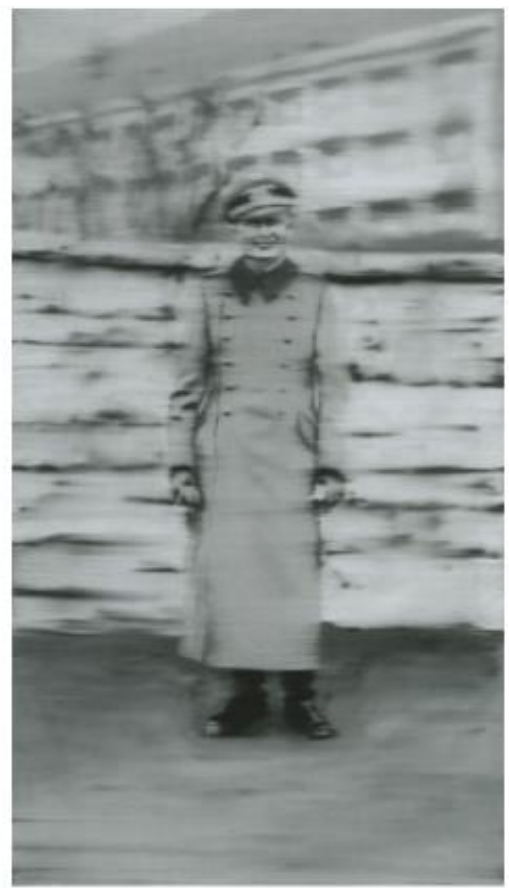

Gerhard Richter (1932):

Onkel Rudi (Tio Rudi), 1965

Óleo sobre tela, $87 \mathrm{~cm} \times 50 \mathrm{~cm}$

Lidice Collection, Lidice, Czech Republic 


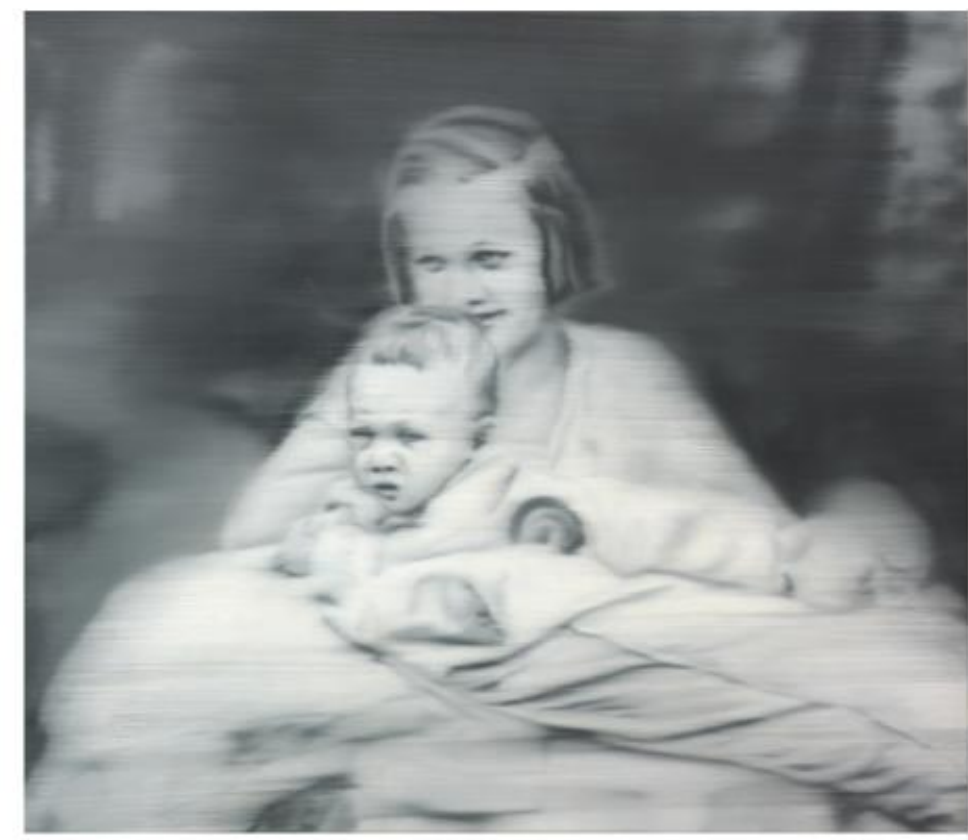

Essa espécie de Madonna é baseada em uma fotografia da Tia de

Richter com ele criança no colo. A fotografia não está no Atlas. Marianne era esquizofrênica e foi

Gerhard Richter (1932): Tante Marianne (tia Marianne), 1965

eliminada pelo programa 104 de eugenia dos nazistas.
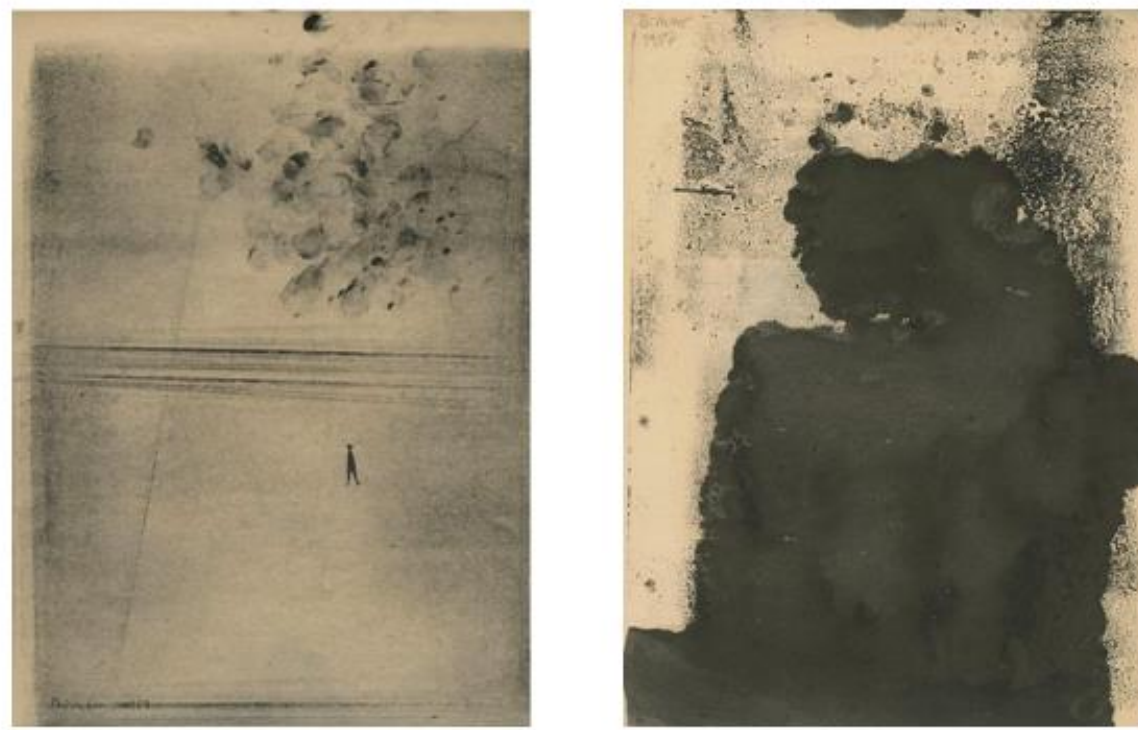

Elbe, 1957

31 monotipias $29.5 \times 21 \mathrm{~cm}$ (each) 

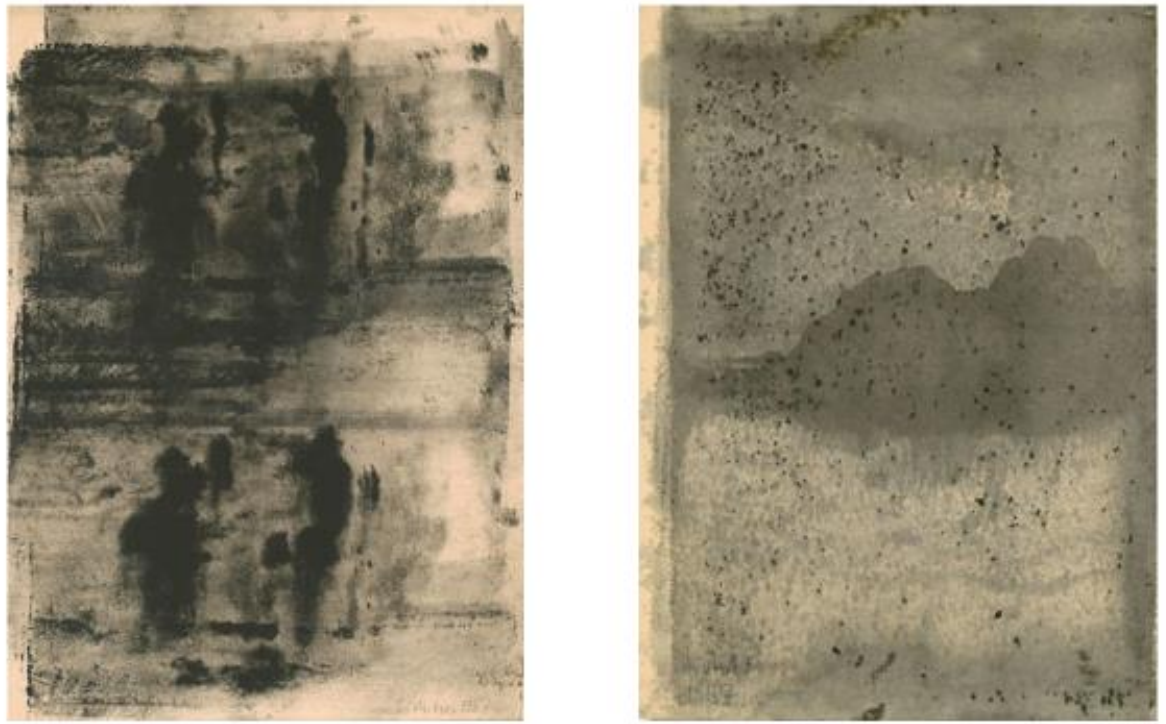

106

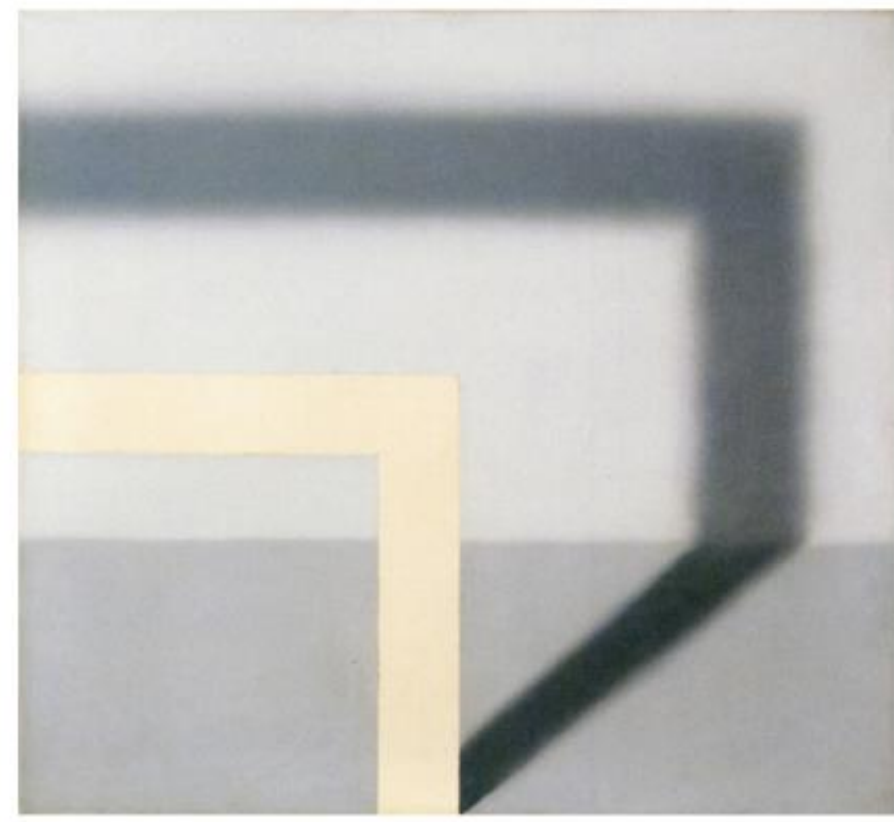

Gerhard Richter (1932): Schattenbild (Silhuetas), 1968

107 Óleo sobre tela, $55 \mathrm{~cm} \times 50 \mathrm{~cm}$ Catalogue Raisonné: 209-02 


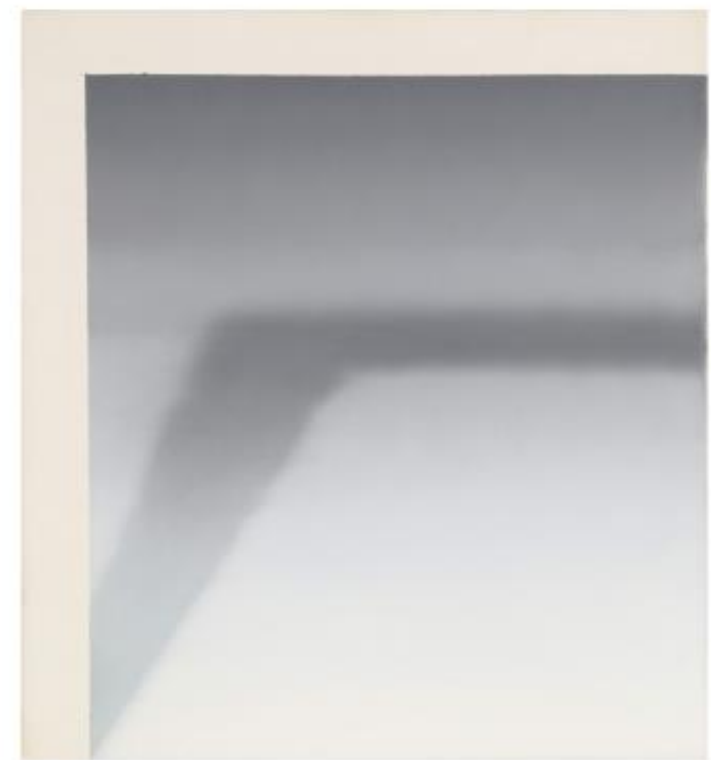

Gerhard Richter (1932): Schattenbild (Silhuetas), 1968

Óleo sobre tela, $55 \mathrm{~cm} \times 50 \mathrm{~cm}$ (Catalogue Raisonné: 209-5)

108

Coleção Privada

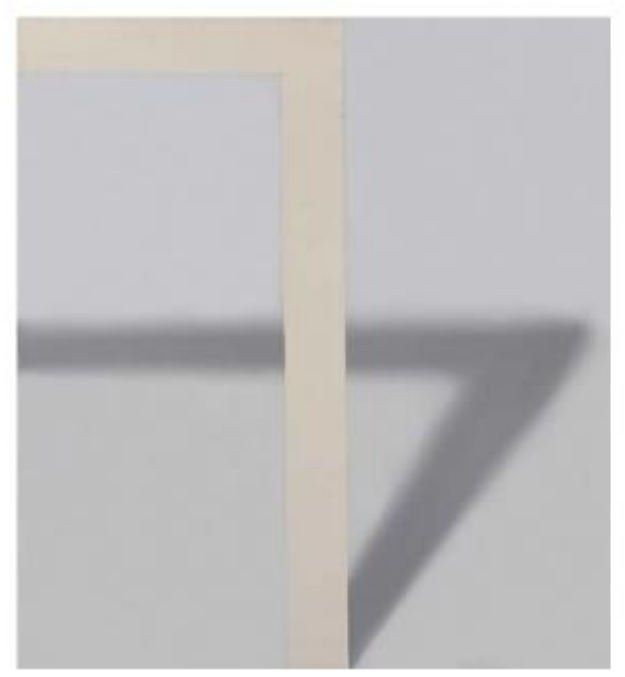

Gerhard Richter (1932): Schattenbild (Silhuetas), 1968

Óleo sobre tela, $55 \mathrm{~cm} \times 50 \mathrm{~cm}$ Catalogue Raisonné: 209-10 Coleção Privada 


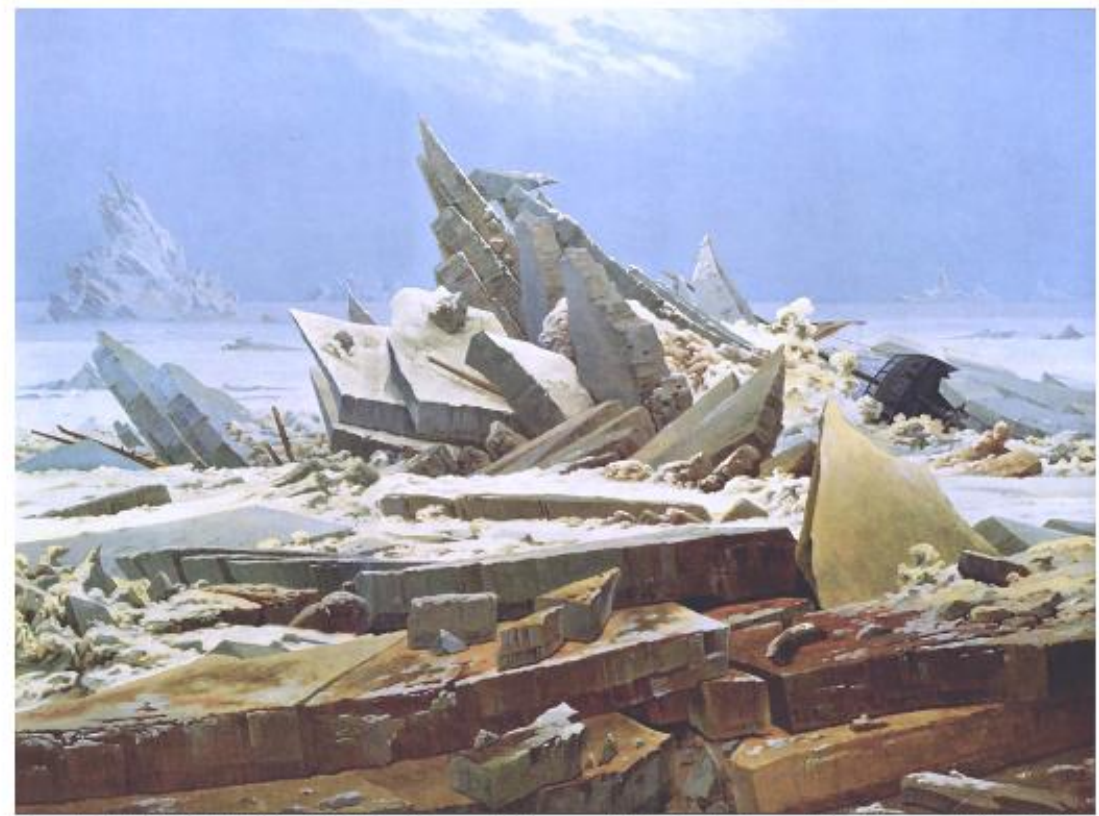

Caspar David Friedrich (1774-1840), Das Eismeer / Die verunglūckte Nordpolexpedition, Die verunglückte Hoffnung (1823 1824). Oll on canvas, $96,7 \times 126,9 \mathrm{~cm}$

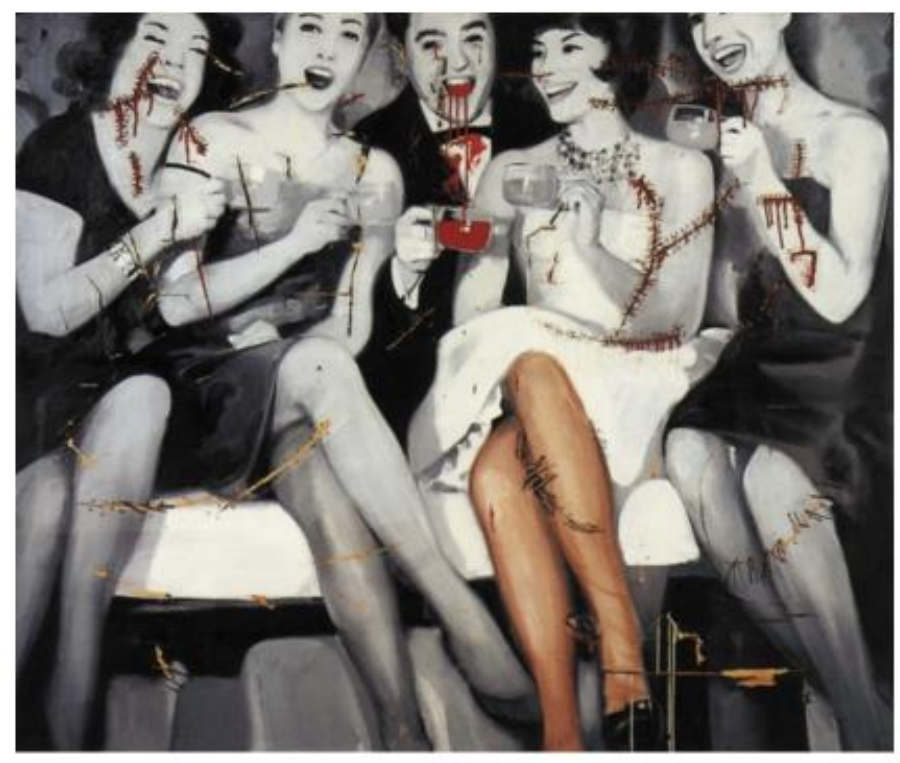

Gerhard Richter (1932): Festa, 1963

Técnica mista, $150 \mathrm{~cm} \times 182 \mathrm{~cm}$

111

Museum Frieder Burda, Baden-Baden,Alemanha 
Gerhard Richter (1932):

Eisläuferin (patinadora), 1962

Óleo sobre tela

$135 \mathrm{~cm} \times 120 \mathrm{~cm}$

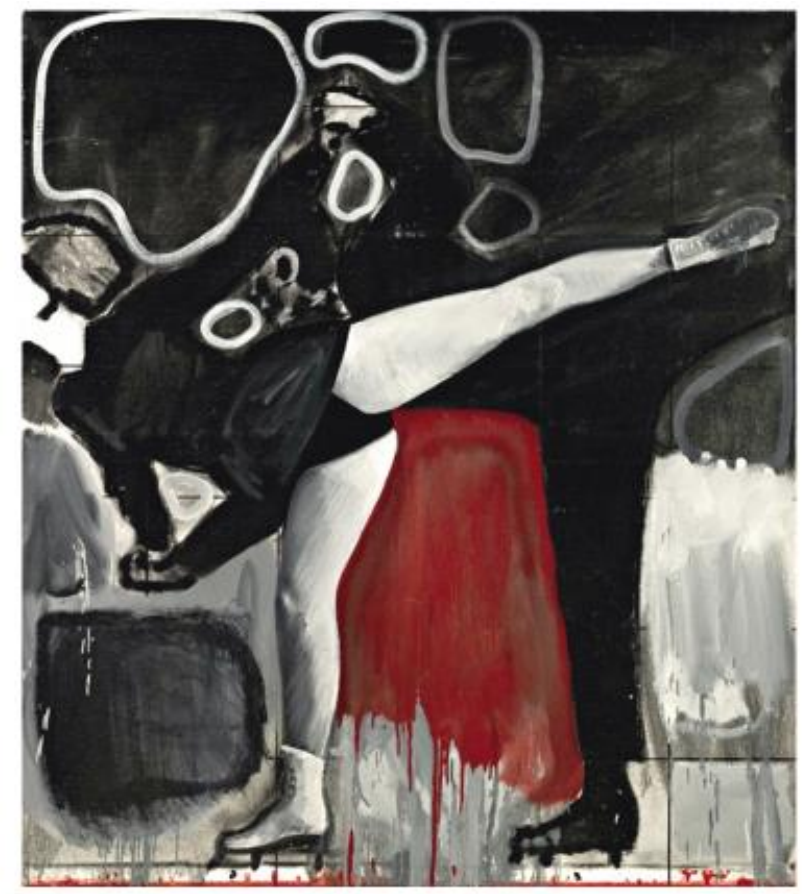

112

113

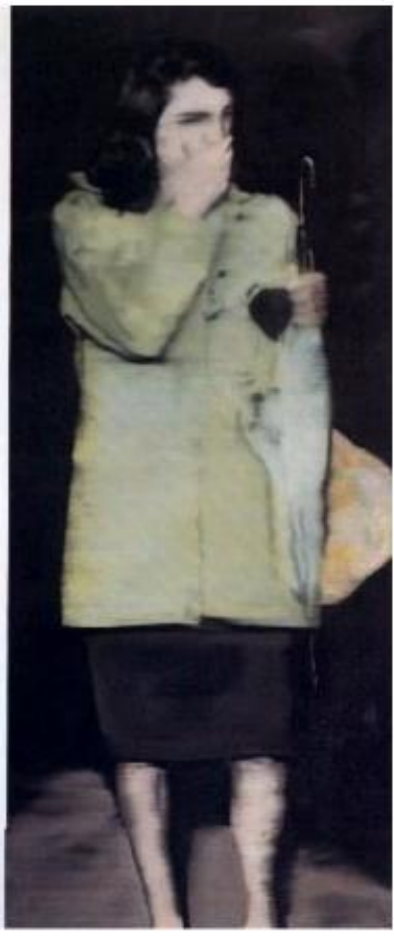

Gerhard Richter (1932)

Mulher com guarda-chuva de 1964

Óleo sobre tela, $60 \times 95 \mathrm{~cm}$

Daros Collection Zurique, Suiça 


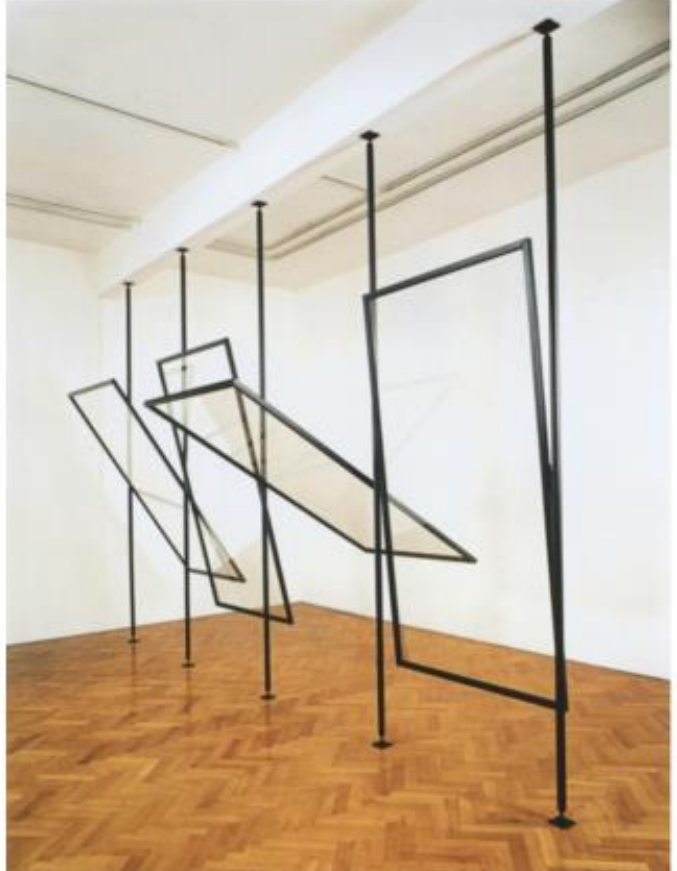

114 115
Gerhard Richter (1932):

4 Glasscheiben

(4 Painéis de vidro), 1967

4 partes, Vidro e ferro,

cada: $190 \mathrm{~cm} \times 100 \mathrm{~cm}$

Herbert Foundation, Ghent, Bélgica
Gerhard Richter (1932)

Eckspiegel, grün-rot

Corner Mirror, Green-Red

$1991225 \mathrm{~cm} \times 100 \mathrm{~cm}$

Colour-coated glass

Artist Room Collection, Tate, London 

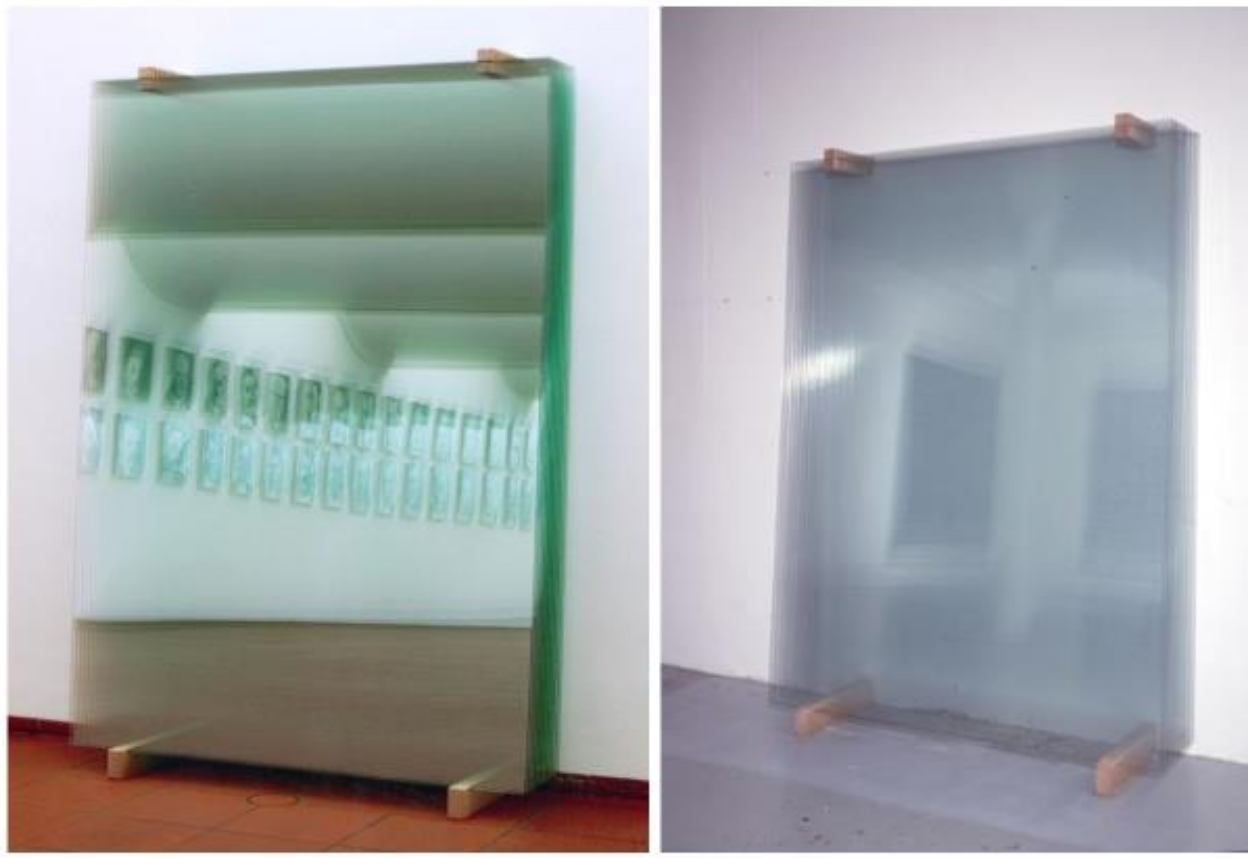

Gerhard Richter (1932): 11 Scheiben (11 Vidraças), 2003 116 Vidro e estrutura de madeira, $229 \mathrm{~cm} \times 160 \mathrm{~cm} \times 51 \mathrm{~cm}$

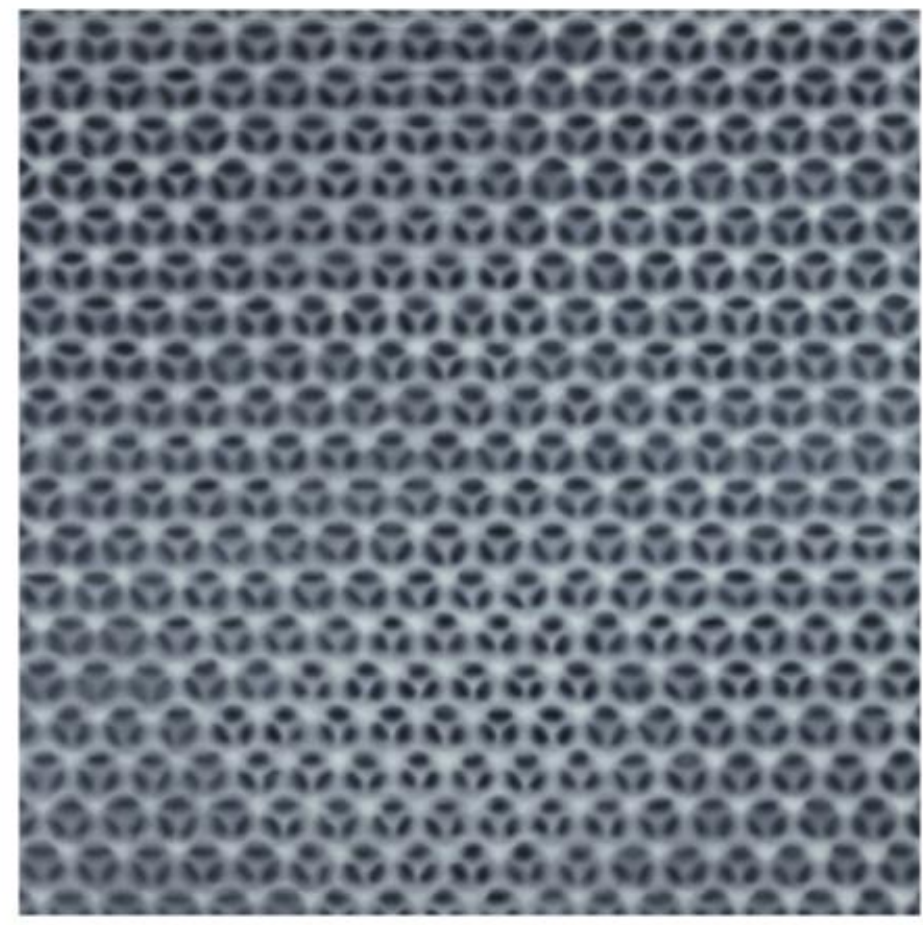

Gerhard Richter (1932)

Silicato, 2003

Óleo sobre tela,

$290 \mathrm{~cm} \times 290 \mathrm{~cm}$

Kunstsammlung

Nordrhein-Westfalen,

Düsseldorf 

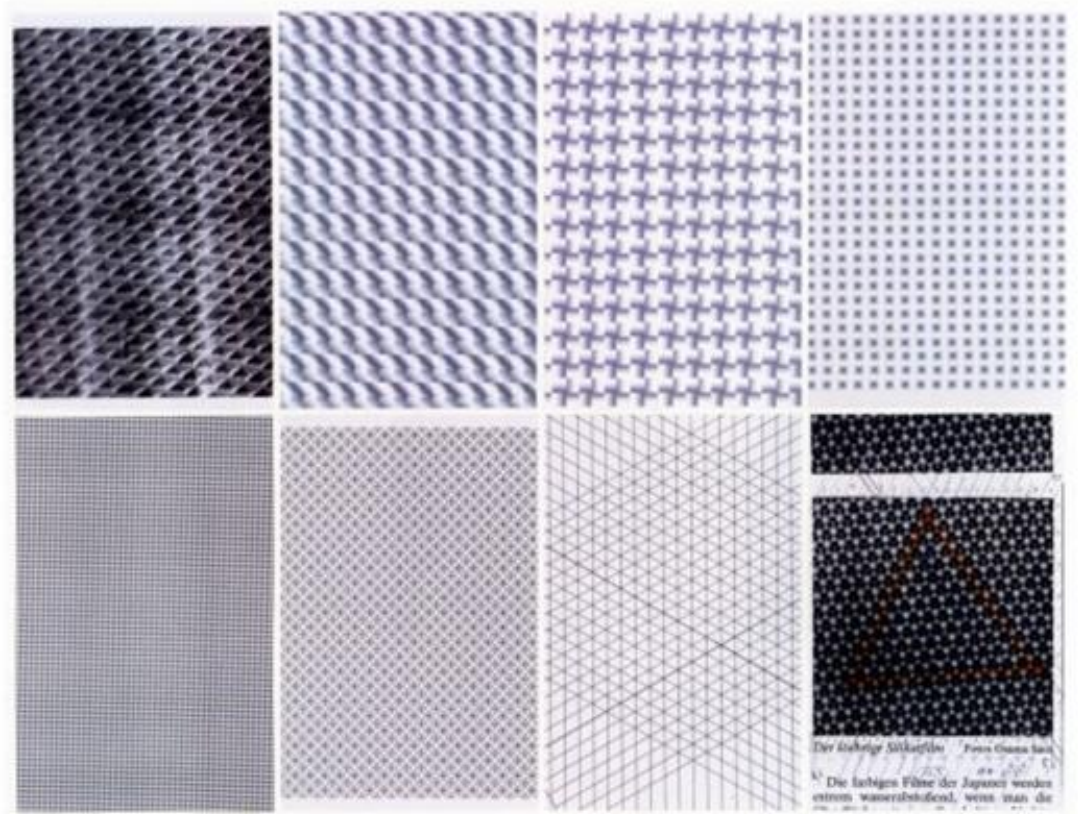

118

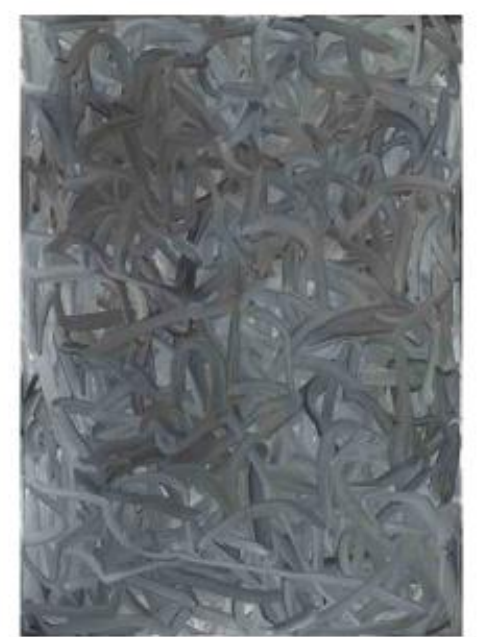

Gerhard Richter (1932)

Cinza (Retrato Albert Einstein), 1972

Óleo sobre tela, $151 \mathrm{~cm} \times 108 \mathrm{~cm}$

Catálogo Raisonné: 323-a

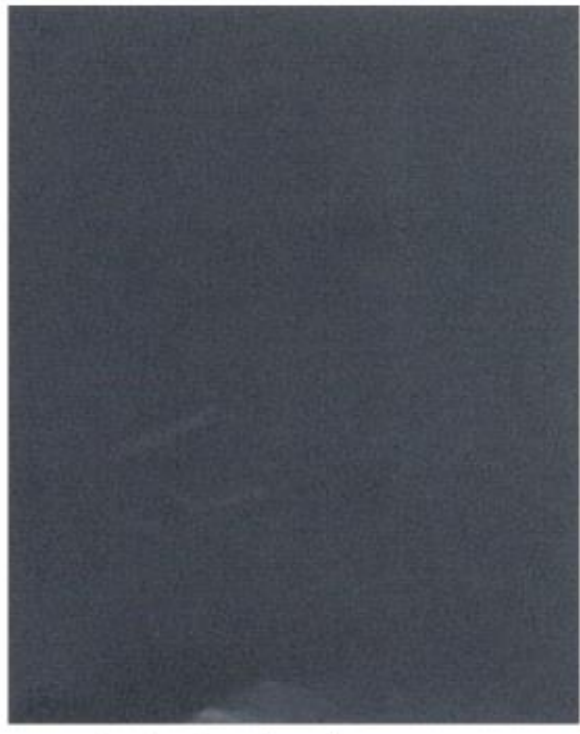

Gerhard Richter (1932): Grau,1972 Oil on canvas, $250 \mathrm{~cm} \times 200 \mathrm{~cm}$ Catalogue Raisonné: 323-a

MKM Museum Küppersmühle für Moderne Kunst, Duisburg, Germany 


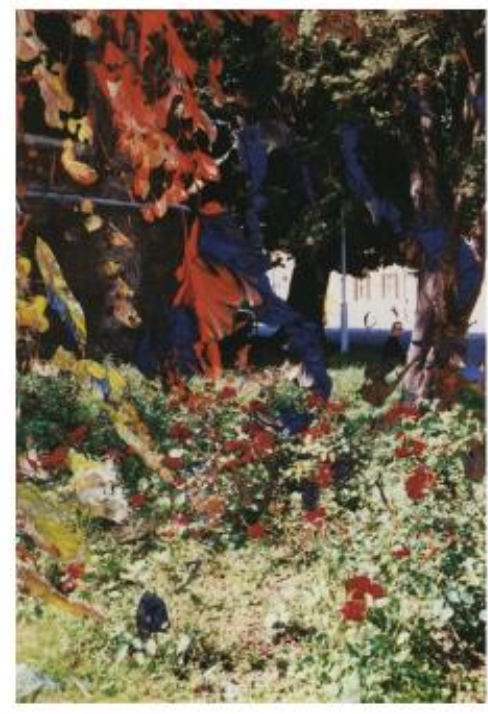

Gerhard Richter (1932)

10.8.89 [Betty],1989

Óleo sobre fotografia colorida, $15 \mathrm{~cm} \times 10.2 \mathrm{~cm}$

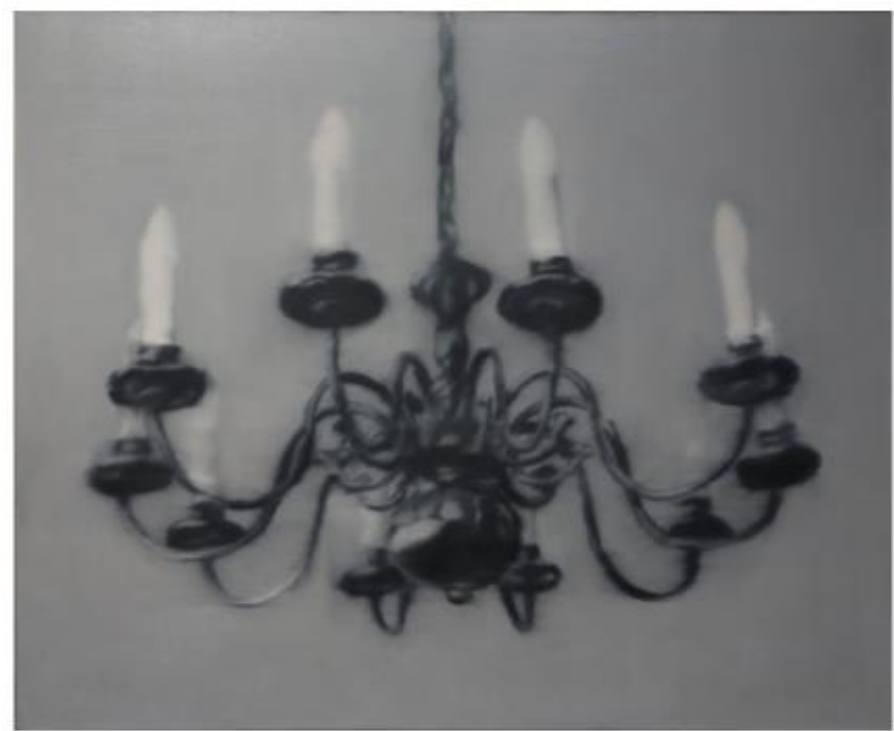

Gerhard Richter (1932)

Flämische Krone, 1965

Óleo sobre tela, $90 \mathrm{~cm} \times 110 \mathrm{~cm}$

121 Catálogo Raisonné: 77 

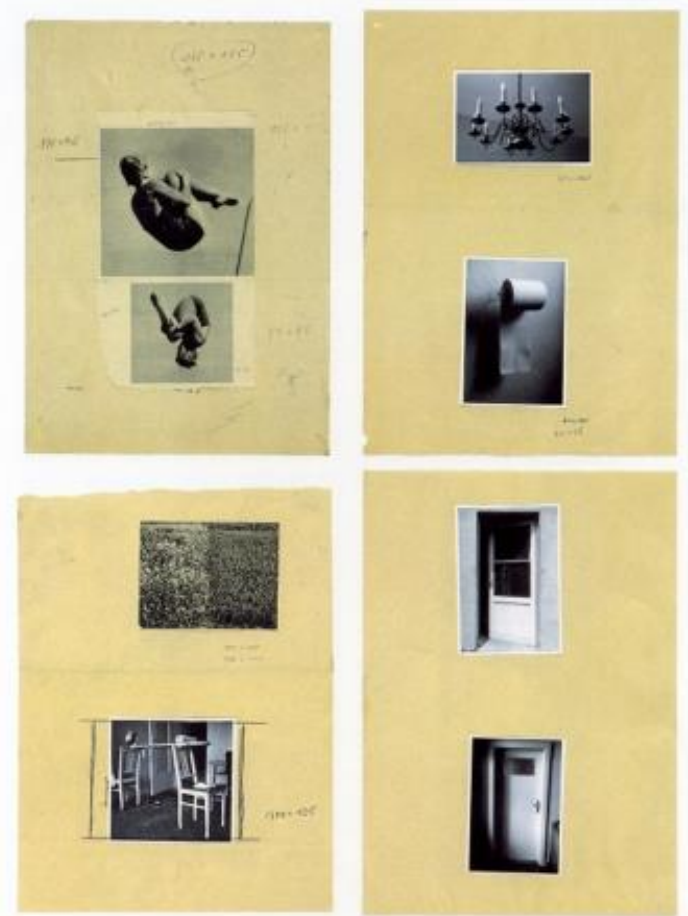

122

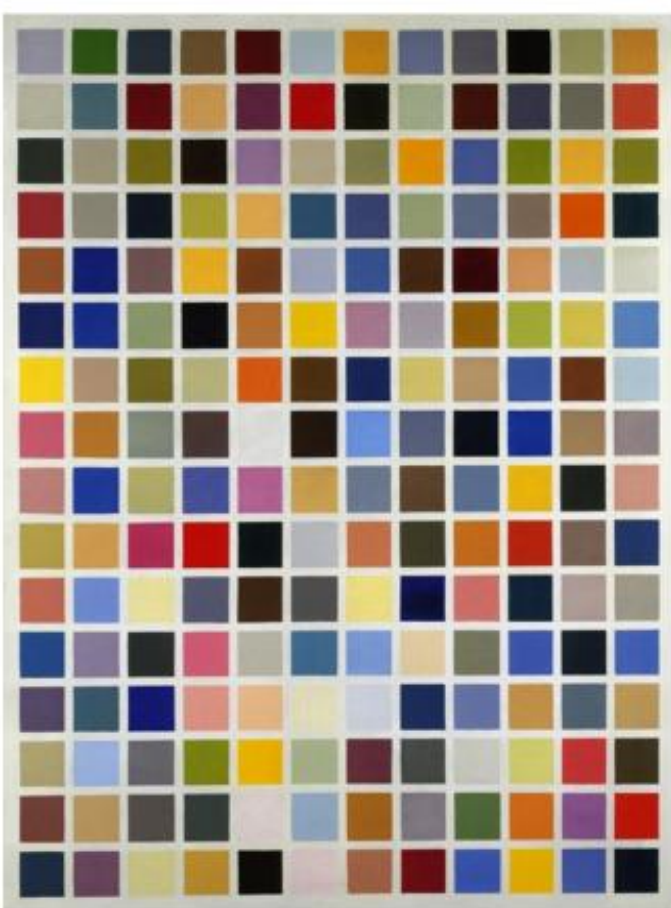

123
Gerhard Richter (1932);

192 Farben (192 Cores), 1966

Óleo sobre tela, $200 \mathrm{~cm} \times 150 \mathrm{~cm}$

Hamburger Kunsthalle,

Hamburgo

(emprestado da coleção de

Elisabeth e Gerhard Sohst) 
Gerhard Richter (1932):

Zwei Grau übereinander(dois cinzas,

um sobre o outro), 1966

Óleo sobre tela, $200 \mathrm{~cm} \times 130 \mathrm{~cm}$

Olbricht Collection, Berlim

124

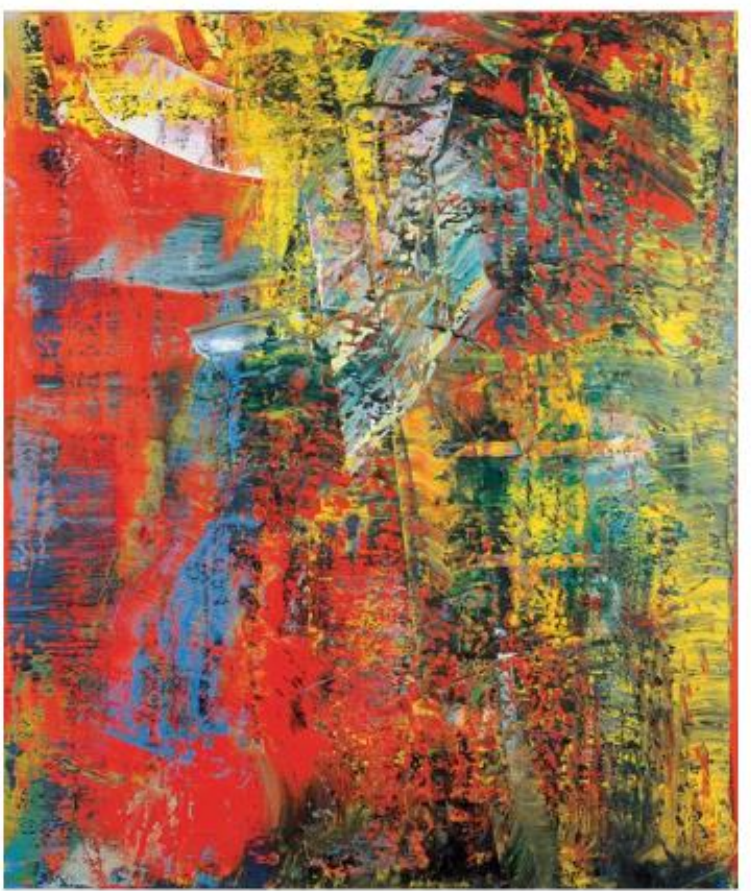

Gerhard Richter (1932):

A B, Courbet, 1986

Oil on canvas, $300 \mathrm{~cm} \times 250 \mathrm{~cm}$ MKM Museum Küppersmühle für Moderne Kunst, Duisburg, Germany 


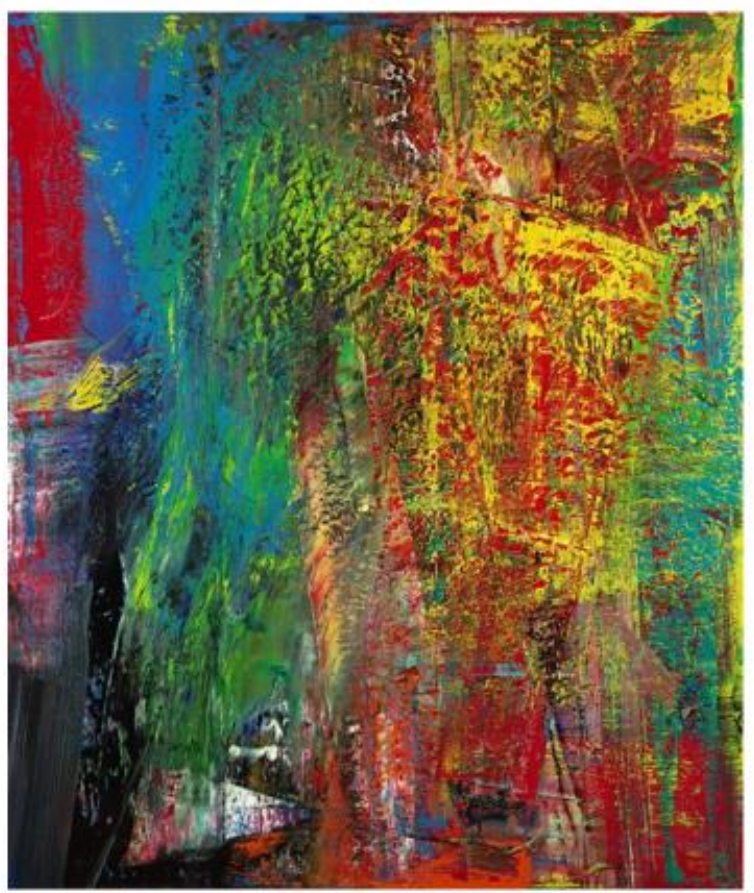

Gerhard Richter (1932):

A B, Courbet, 1986

Oil on canvas, $300 \mathrm{~cm} \times 250 \mathrm{~cm}$

Coleção Privada

126

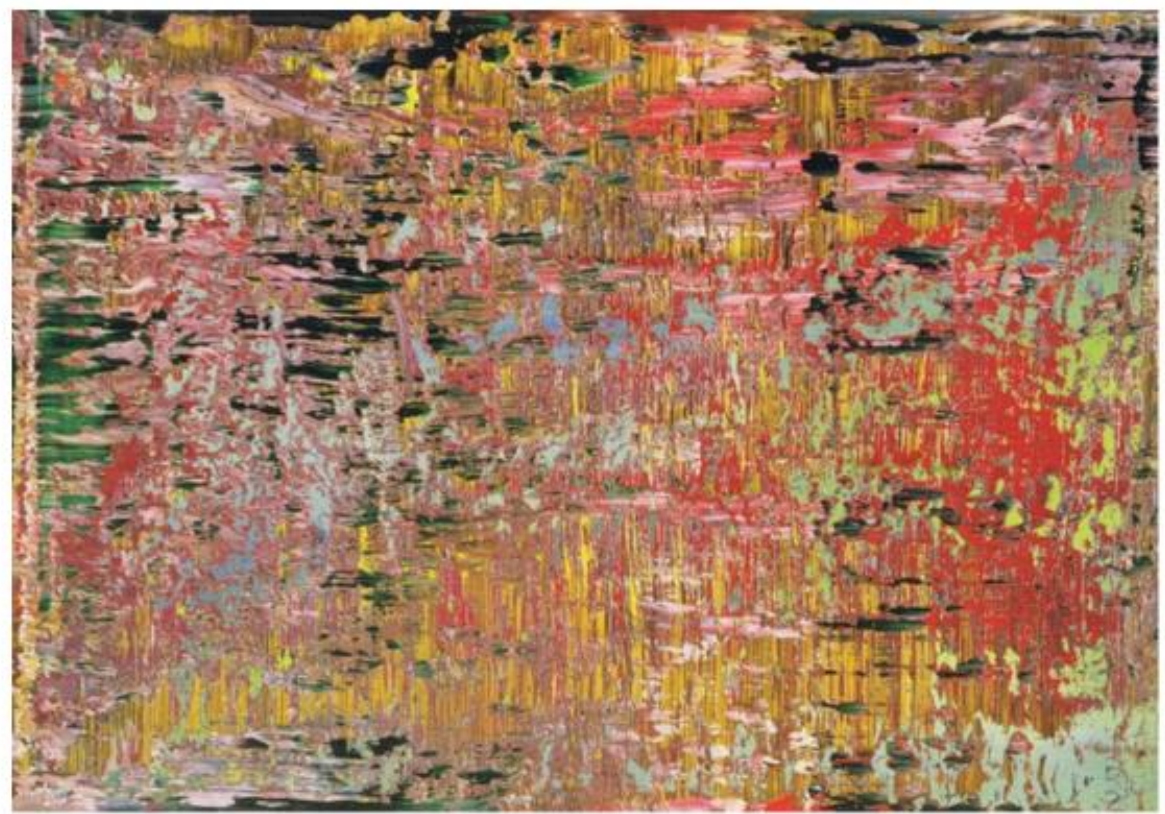

Gerhard Richter (1932): Abstraktes Bild, 1989

127

Oil on canvas, $72 \mathrm{~cm} \times 102 \mathrm{~cm}$ 


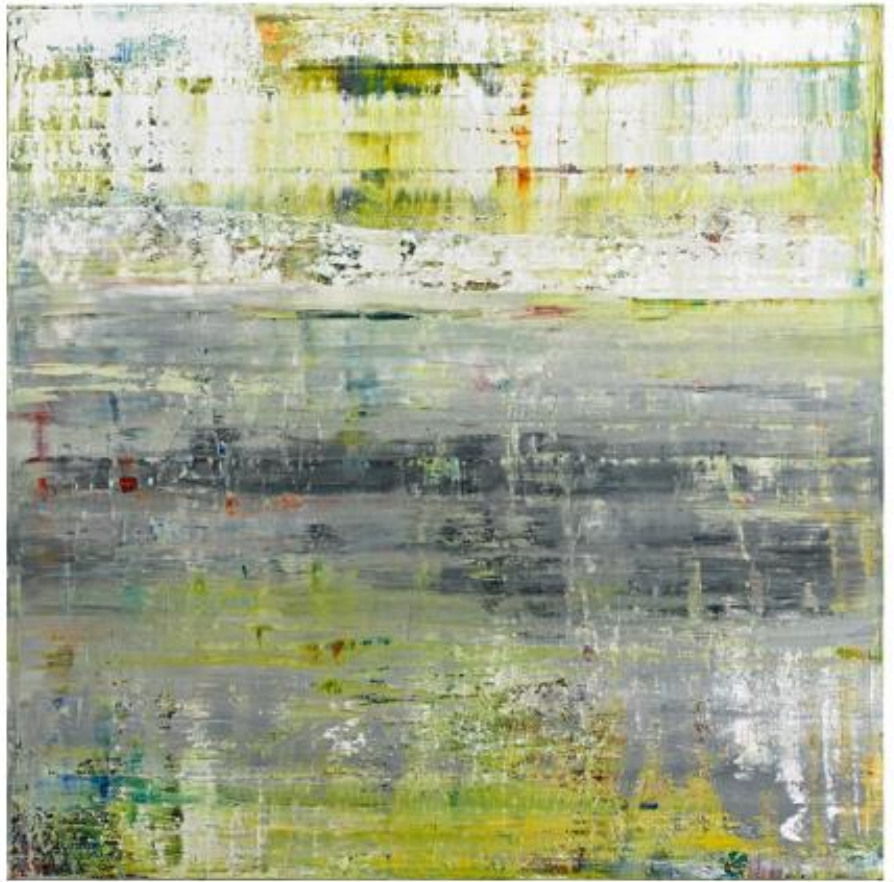

Gerhard Richter (1932)

Cage 2 (2006)

Óleo sobre tela,

$300 \mathrm{~cm} \times 300 \mathrm{~cm}$

Tate Modern, Londres

128

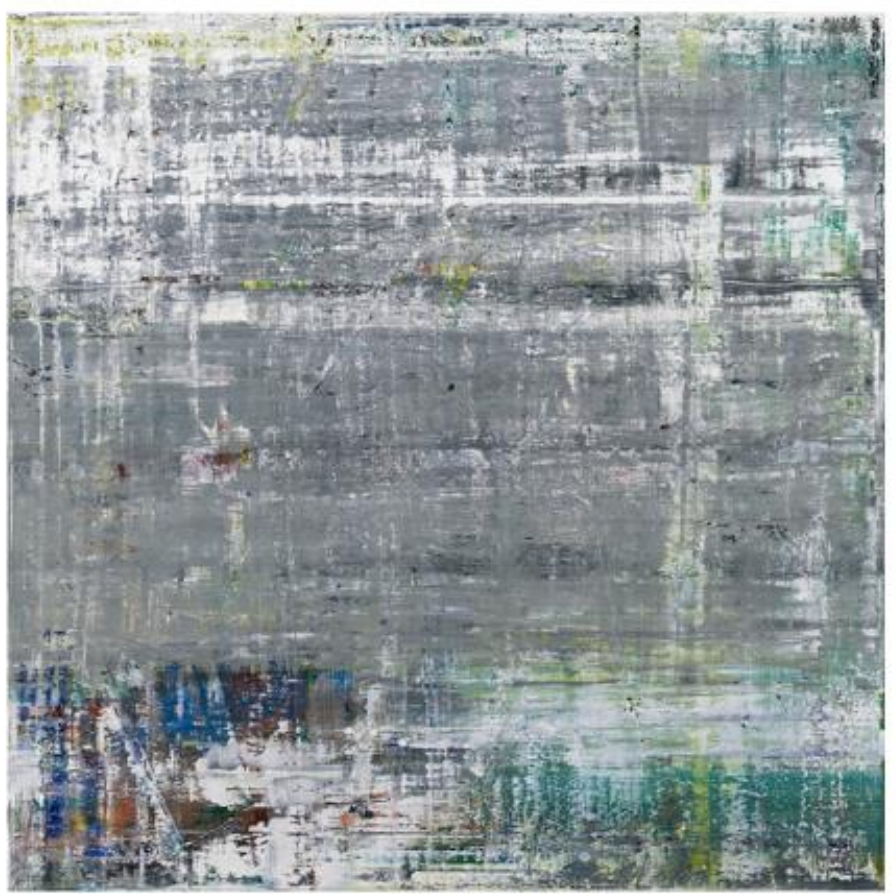

Gerhard Richter (1932)

Cage 3, 2006

Óleo sobre tela,

$290 \mathrm{~cm} \times 290 \mathrm{~cm}$

Tate 


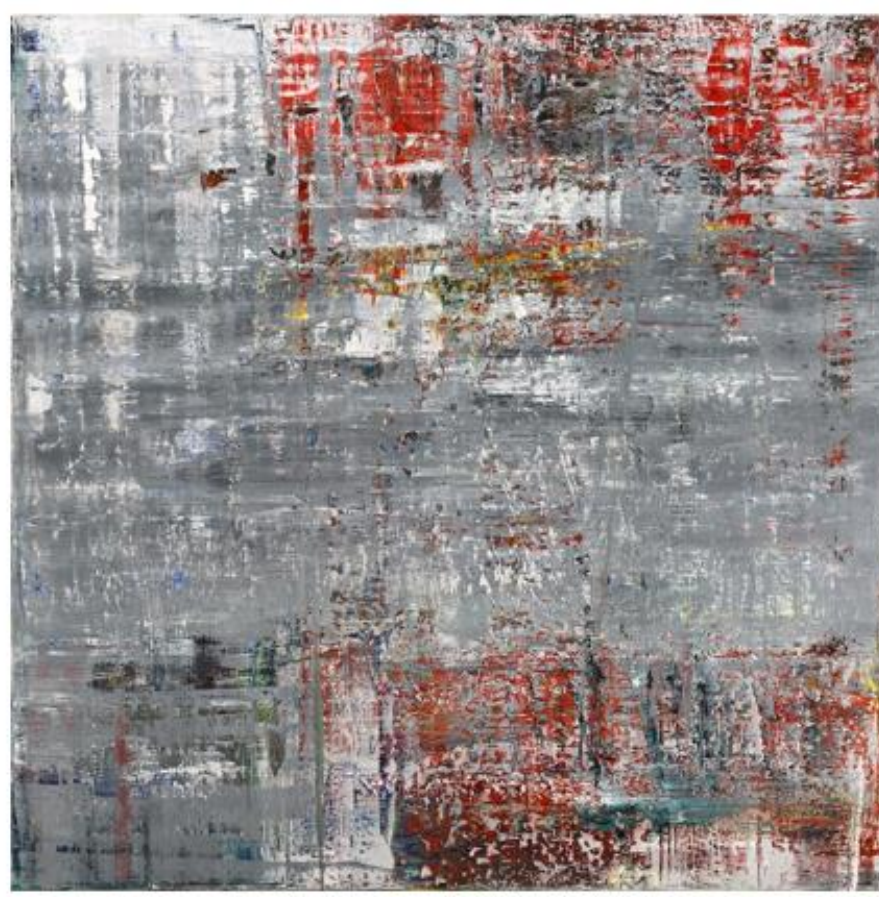

Gerhard Richter (1932)

Cage 4, 2006

Óleo sobre tela,

$290 \mathrm{~cm} \times 290 \mathrm{~cm}$

Tate

130

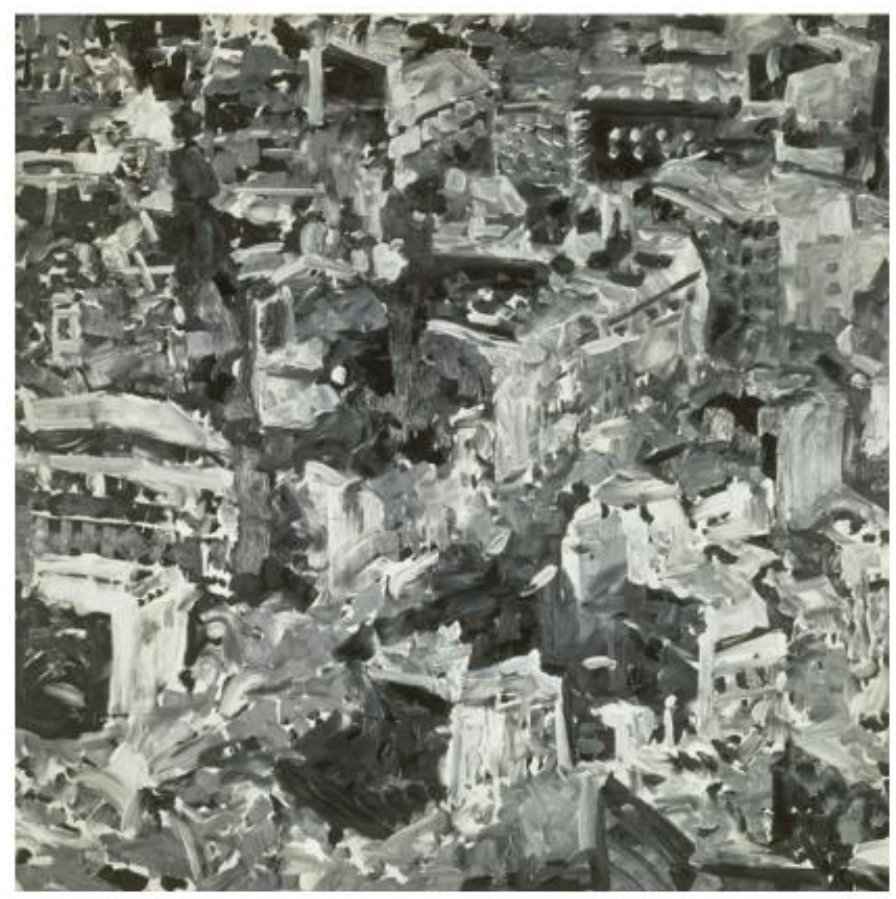

$\stackrel{\infty}{\circ}$

는

ป है

है छ

澡。

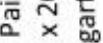

जह

oิ 웅

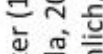

专

똔

흠 융

동흉

131 


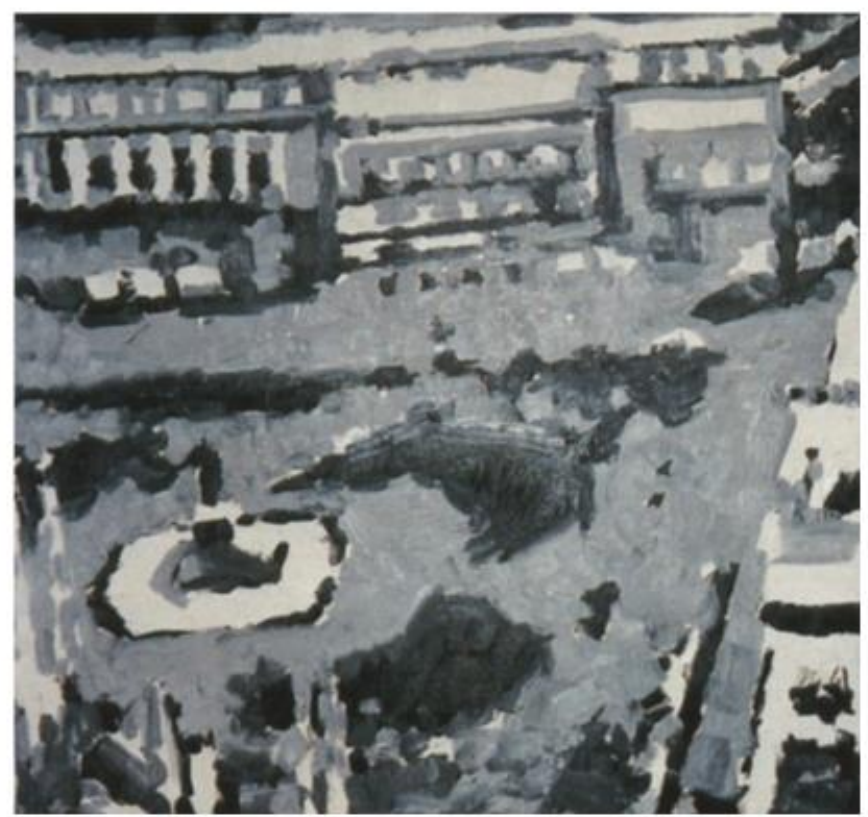

Gerhard Richter (1932):

Stadtbild M6,1968

Oil on canvas

$85 \mathrm{~cm} \times 90 \mathrm{~cm}$

Coleção particular

132

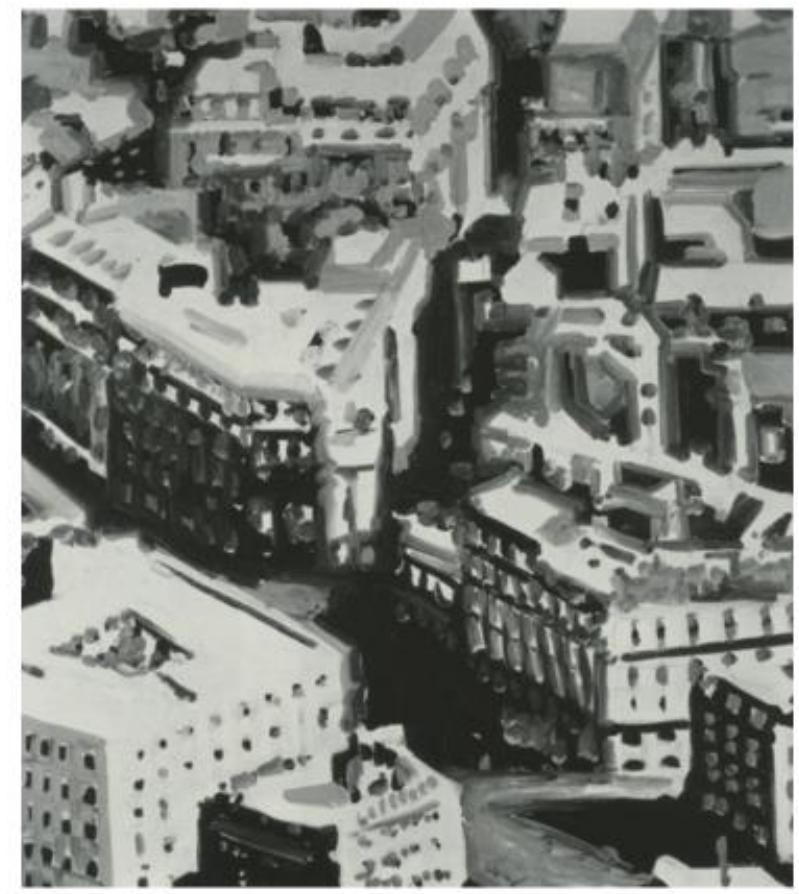

Gerhard Richter (1932):

Stadtbild P1

Townscape P1, 1968

Oil on canvas, $102 \mathrm{~cm} \times 92 \mathrm{~cm}$

Coleção Privada

133 


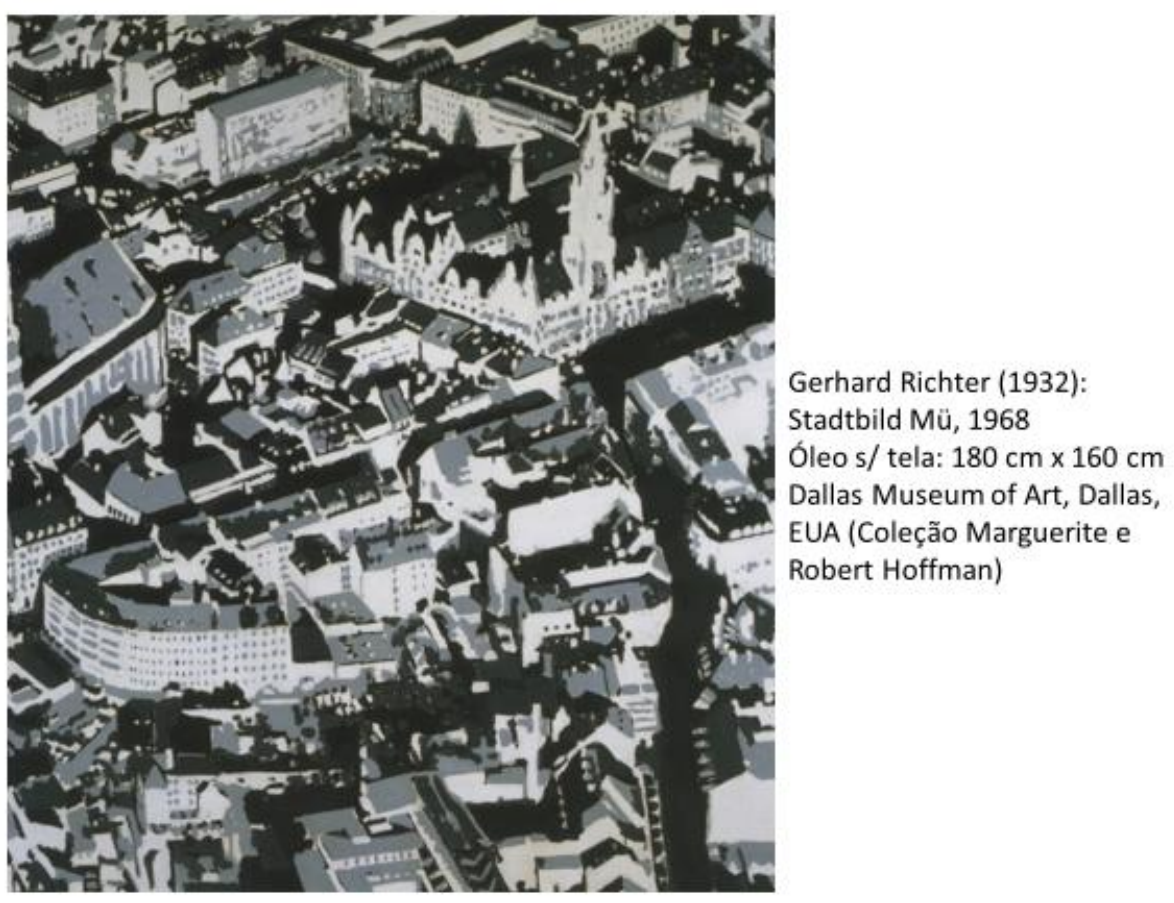

134
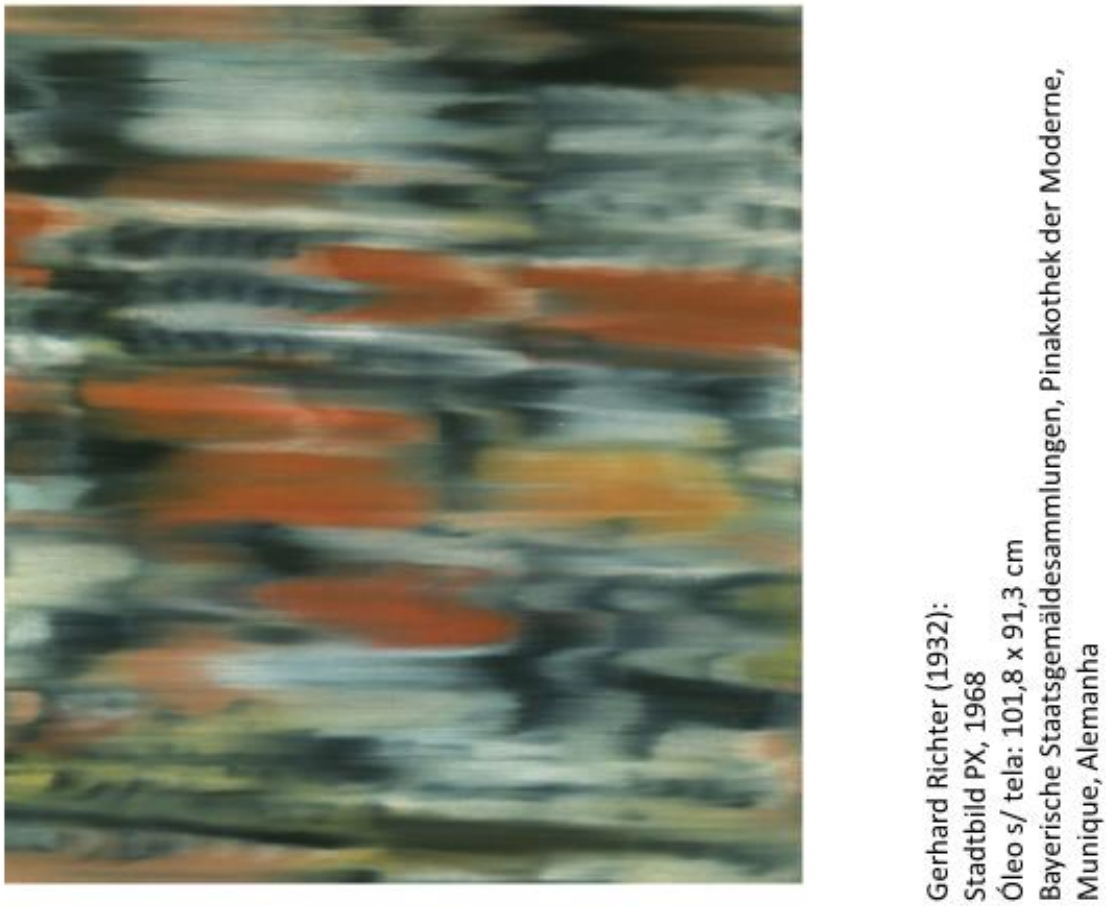


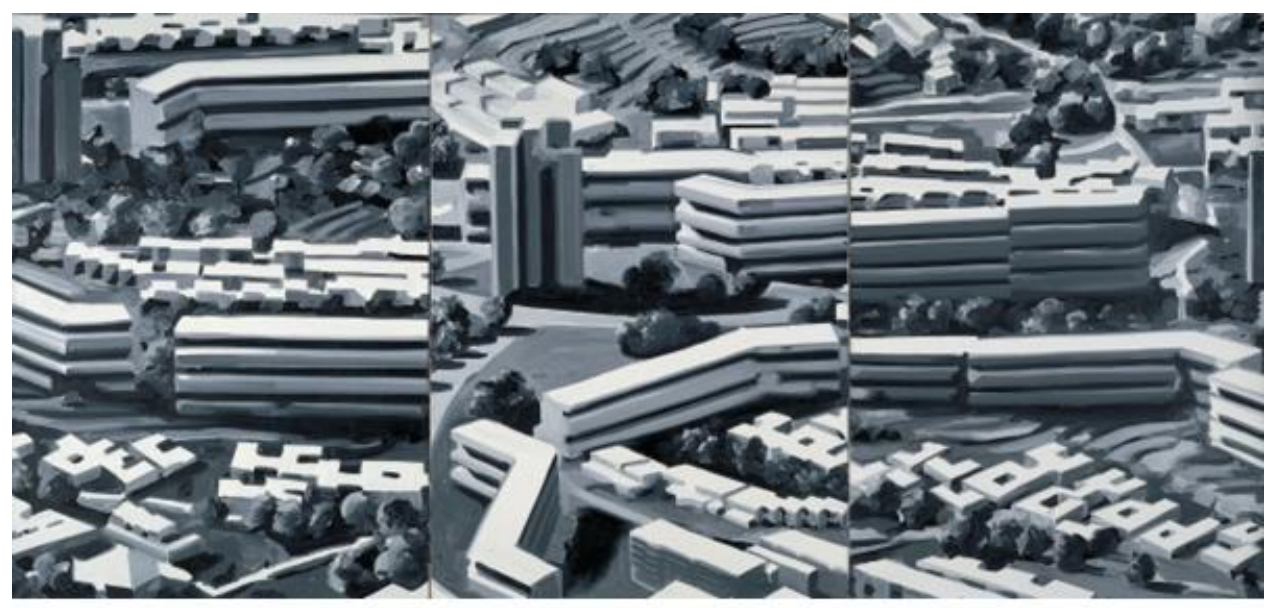

Gerhard Richter (1932):

Stadtbild TR (Paisagem Urbana), 1969

Óleo sobre tela, cada painel: $174 \mathrm{~cm} \times 124 \mathrm{~cm}$ Catálogo Raisonné: 217 / 1-3

Museum Frieder Burda, Baden-Baden, Alemanha

136

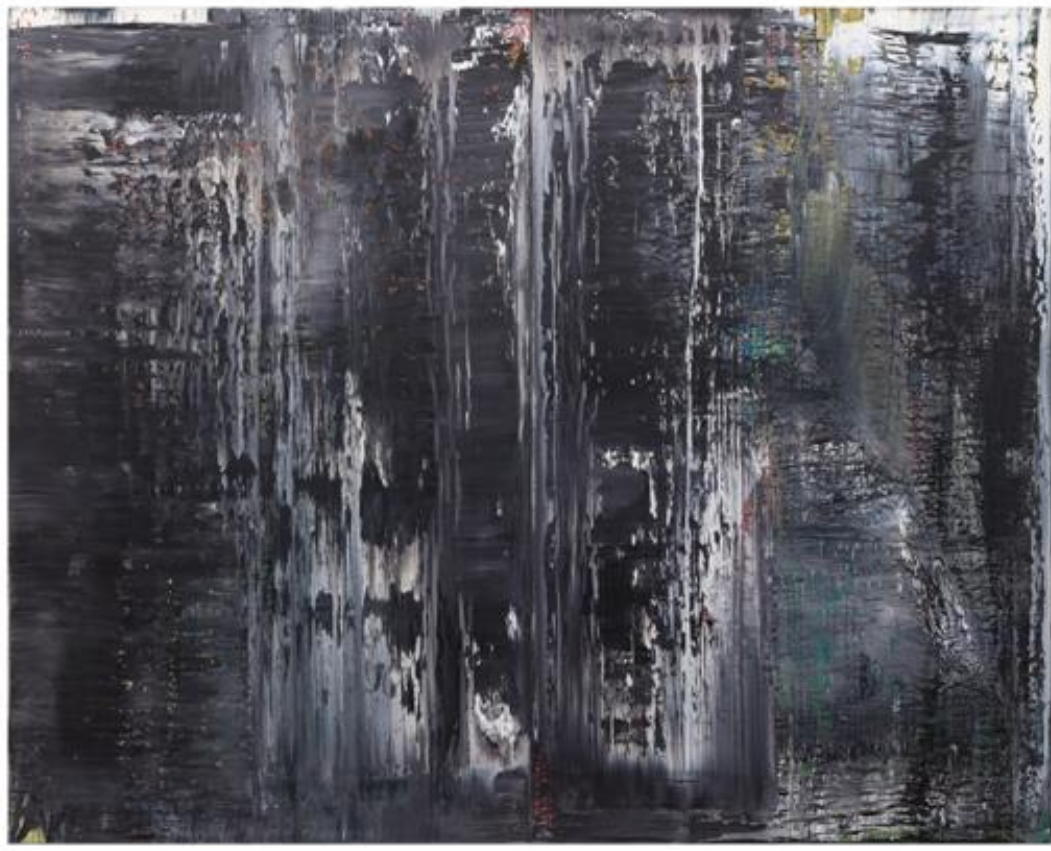

ஓ

$\varepsilon$

要 8

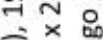

을

है ᄋ

m

음

高

틍 웅

汇

实

氜

음

N

焉

o

응

눙

동응 


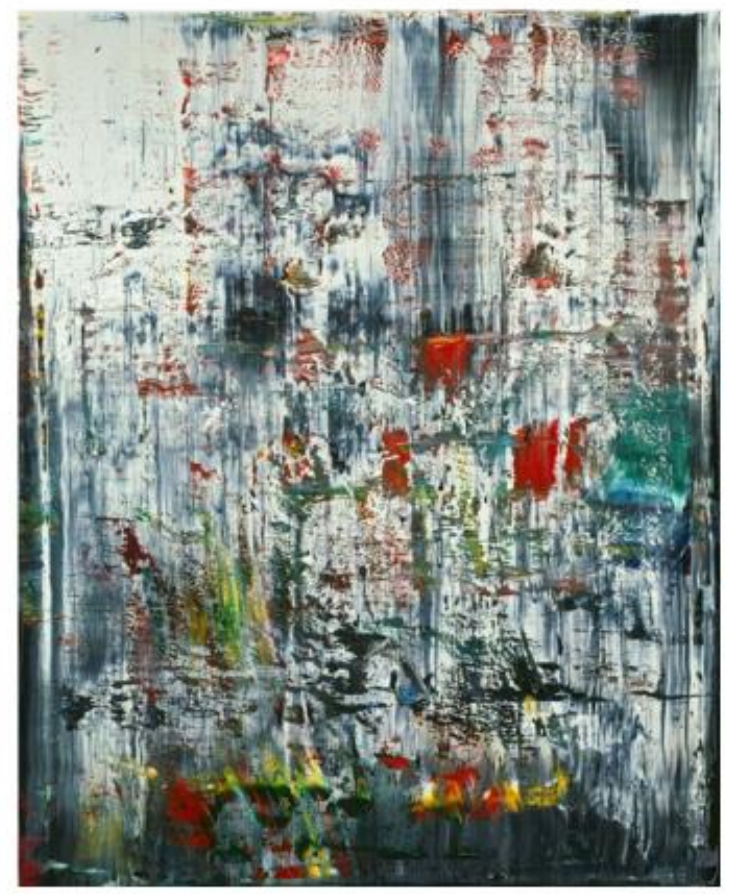

Gerhard Richter (1932): Eis (2)

(gelo, 2), 1989

óleo sobre tela, $200 \mathrm{~cm} \times 160 \mathrm{~cm}$

The Art Institute of Chicago,

Chicago, EUA

Catalogue Raisonné: 706-2

138

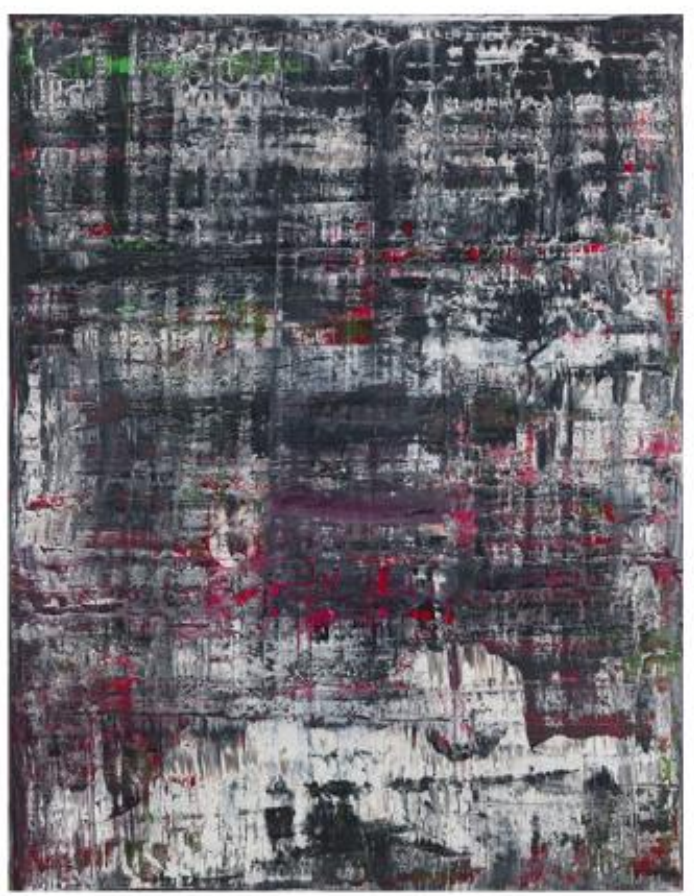

Gerhard Richter (1932),

Birkenau 1 (937-1), 2014

Óleo sobre tela,

$260 \times 200 \mathrm{~cm}$

Gerhard Richter Archiv, Staatliche

Kunstsammlungen Dresden, Dresden 


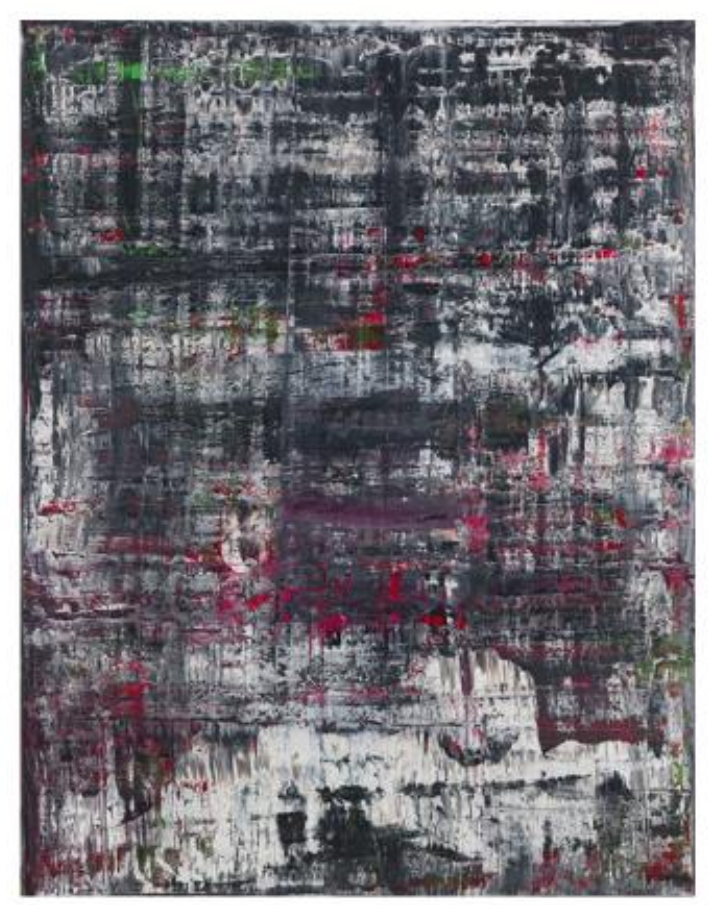

140

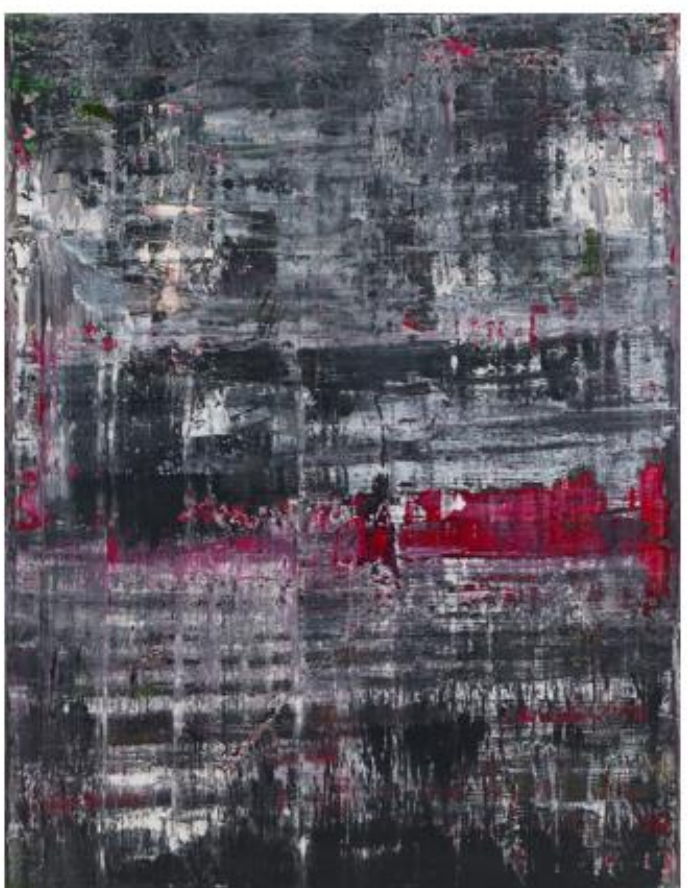

141
Gerhard Richter (1932),

Birkenau 1 (937-1), 2014

Óleo sobre tela,

$260 \times 200 \mathrm{~cm}$

Gerhard Richter Archiv, Staatliche

Kunstsammlungen Dresden, Dresden

Gerhard Richter (1932),

Birkenau 2 (937-1), 2014

Óleo sobre tela,

$260 \times 200 \mathrm{~cm}$

Gerhard Richter Archiv, Staatliche

Kunstsammlungen Dresden, Dresden 


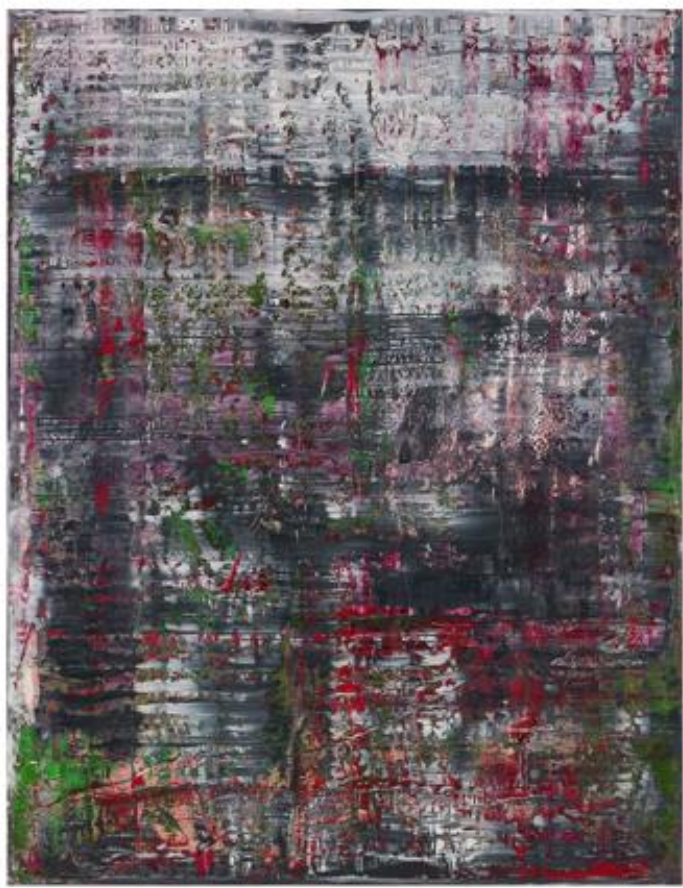

Gerhard Richter (1932),

Birkenau 3 (937-3), 2014

Óleo sobre tela,

$260 \times 200 \mathrm{~cm}$

Gerhard Richter Archiv, Staatliche

Kunstsammlungen Dresden, Dresden

142

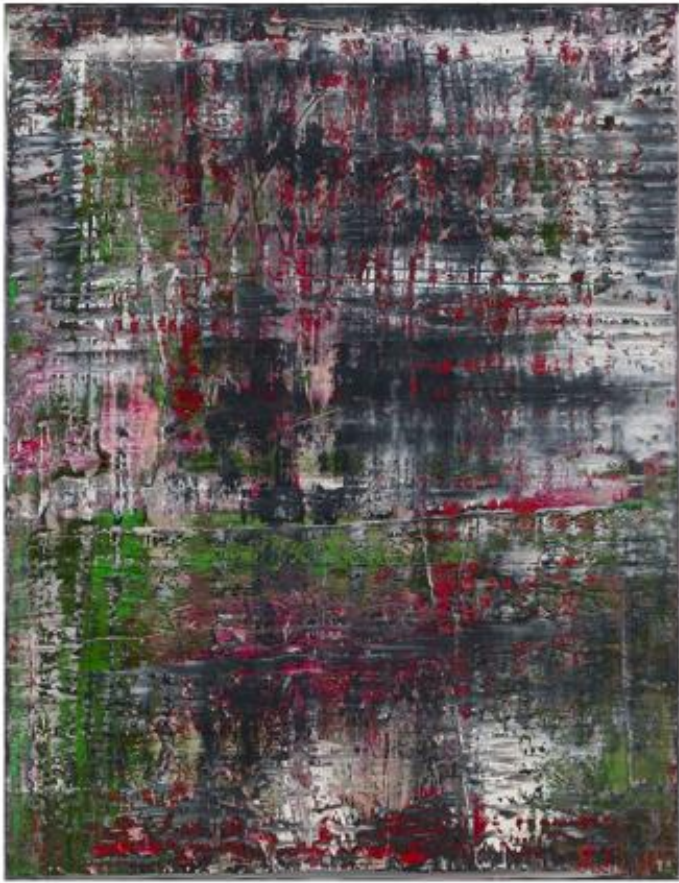

Gerhard Richter (1932),

Birkenau 4 (937-4), 2014

Óleo sobre tela,

$260 \times 200 \mathrm{~cm}$

Gerhard Richter Archiv, Staatliche

Kunstsammlungen Dresden, Dresden

143 


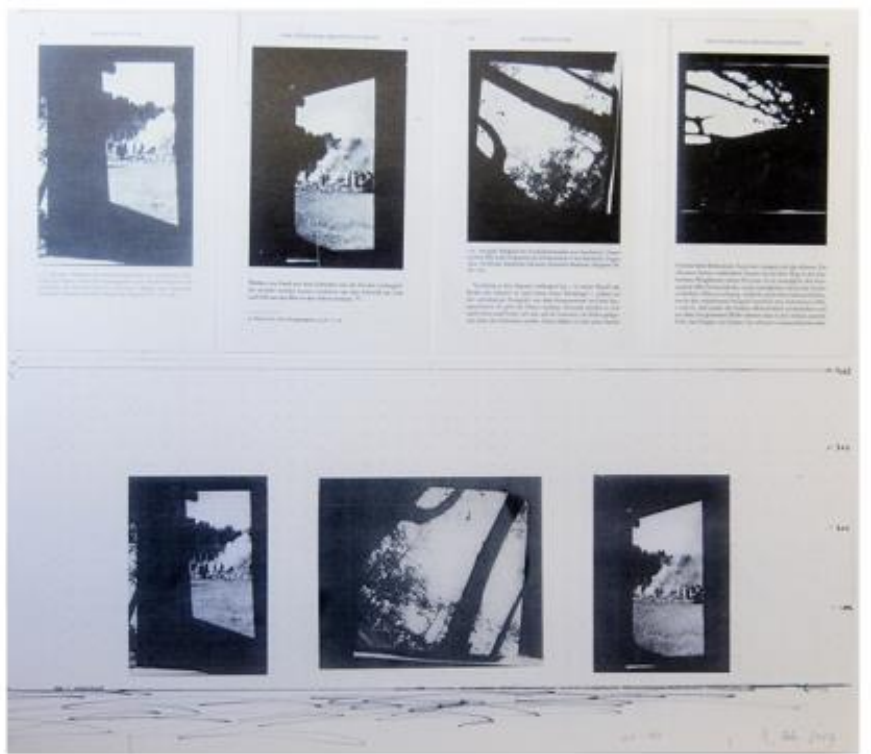

Gerhard Richter (1932): Studien für Birkenau (Estudos para Birkenau), 2013 Folha do Atlas: $808,50 \times 70 \mathrm{~cm}$

144

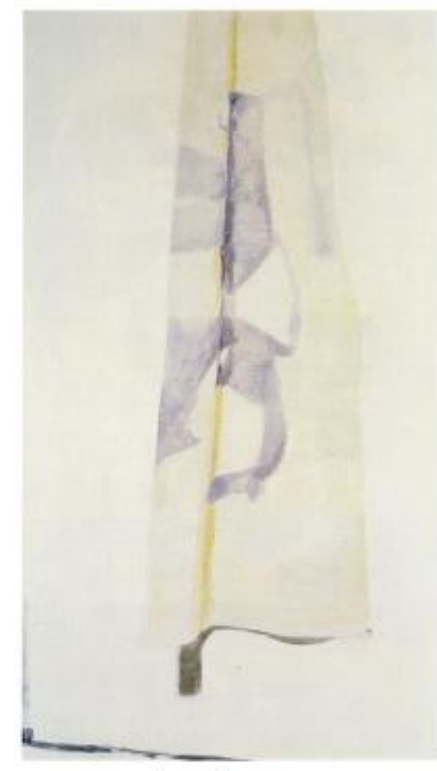

Luc Tuymans (1958)

A bandeira, 1995.

Óleo sobre tela, $138,1 \times 78,1 \mathrm{~cm}$

145
M HKA, Antuérpia, Bélgica

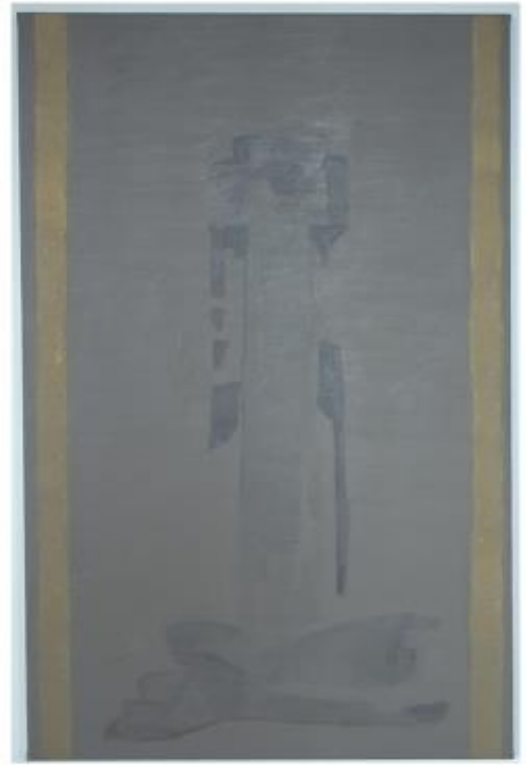

Luc Tuymans (1958)

ljzertoren [Torre Yser] , 1995

Óleo sobre tela, $15,5 \times 75,5 \mathrm{~cm}$

M HKA, Antuérpia, Bélgica 


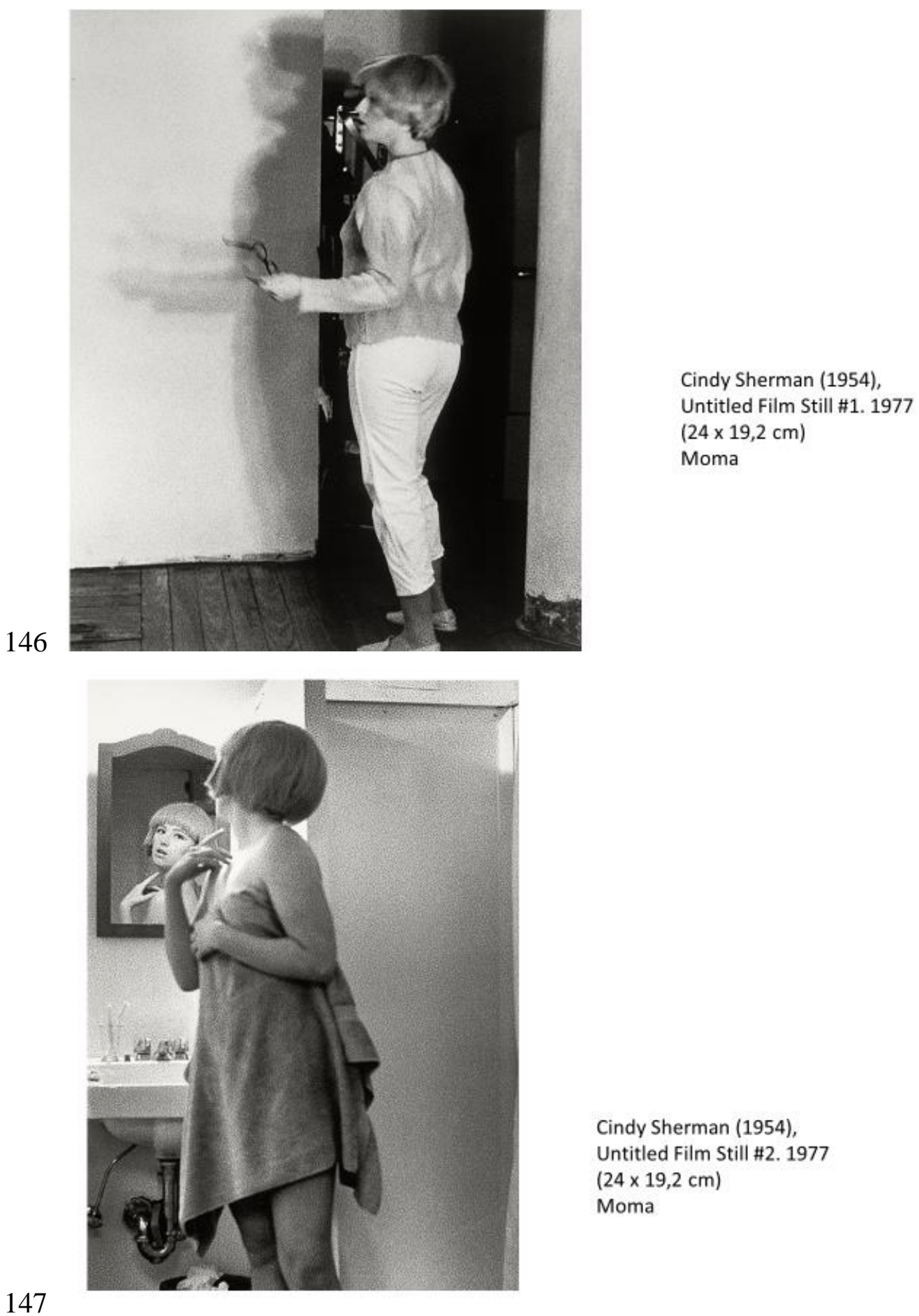




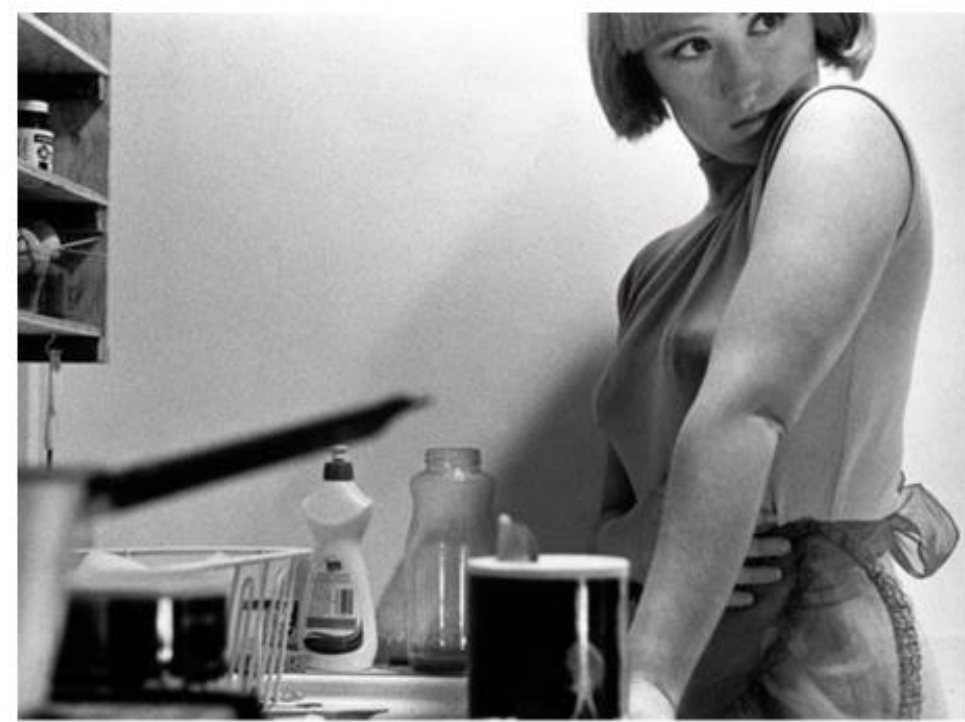

Cindy Sherman (1954),

Untitled Film Still \#3. 1977

$(19,2 \times 24 \mathrm{~cm})$

148

Moma

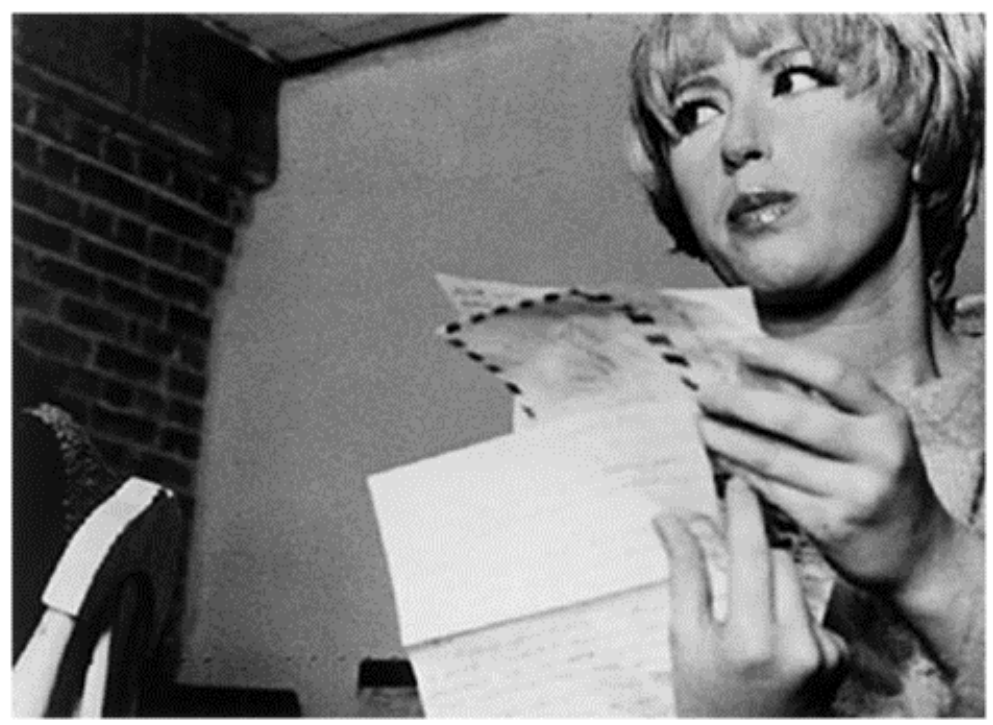

Cindy Sherman (1954),

Untitled Film Still \#3. 1977

$(19,2 \times 24 \mathrm{~cm})$ 


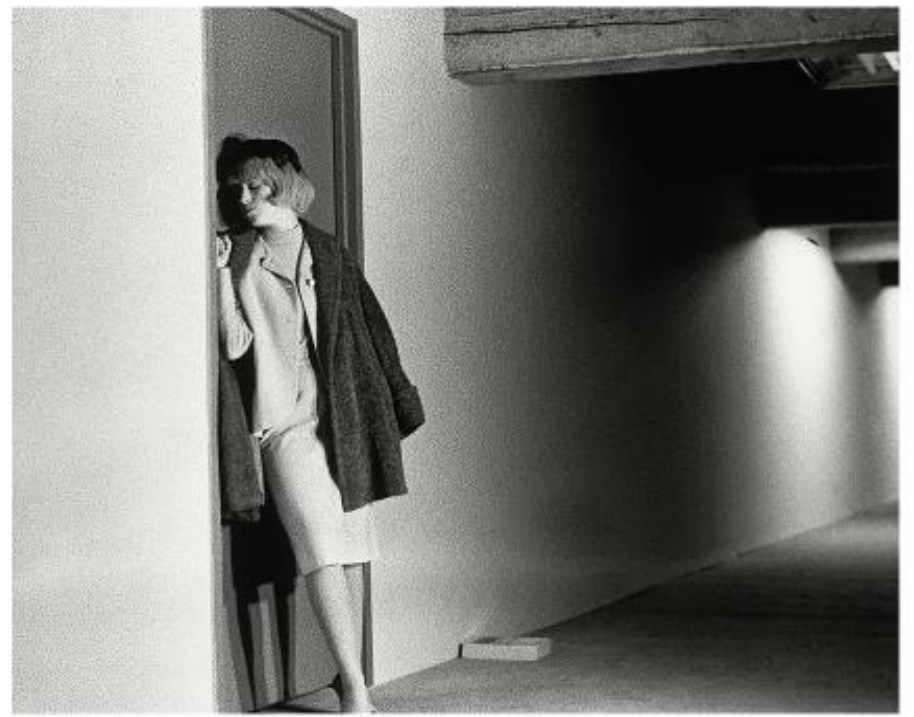

Cindy Sherman (1954),

Untitled Film Still \#3. 1977

$(19,2 \times 24 \mathrm{~cm})$

150

Moma

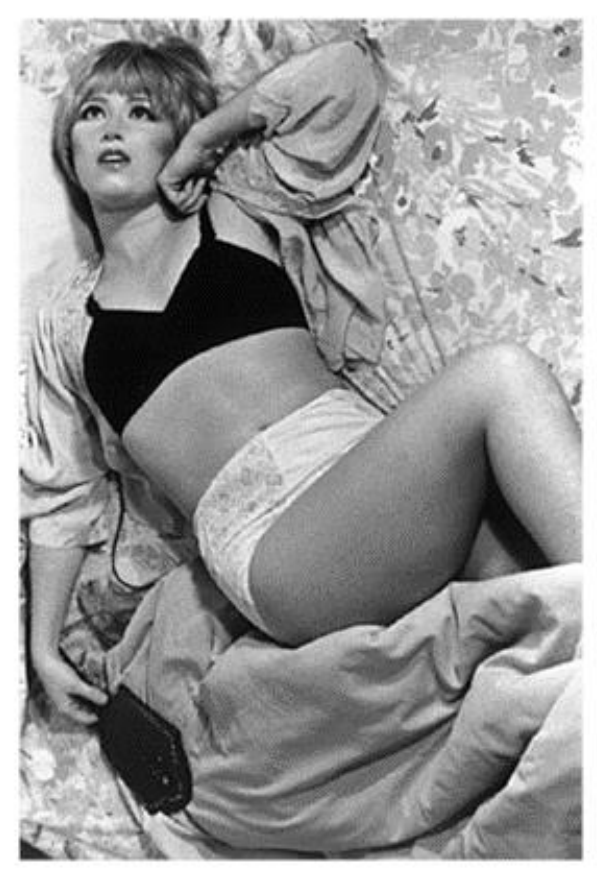

Cindy Sherman (1954),

Untitled Film Still \#6. 1977

$(24 \times 19,2 \mathrm{~cm})$

Moma 


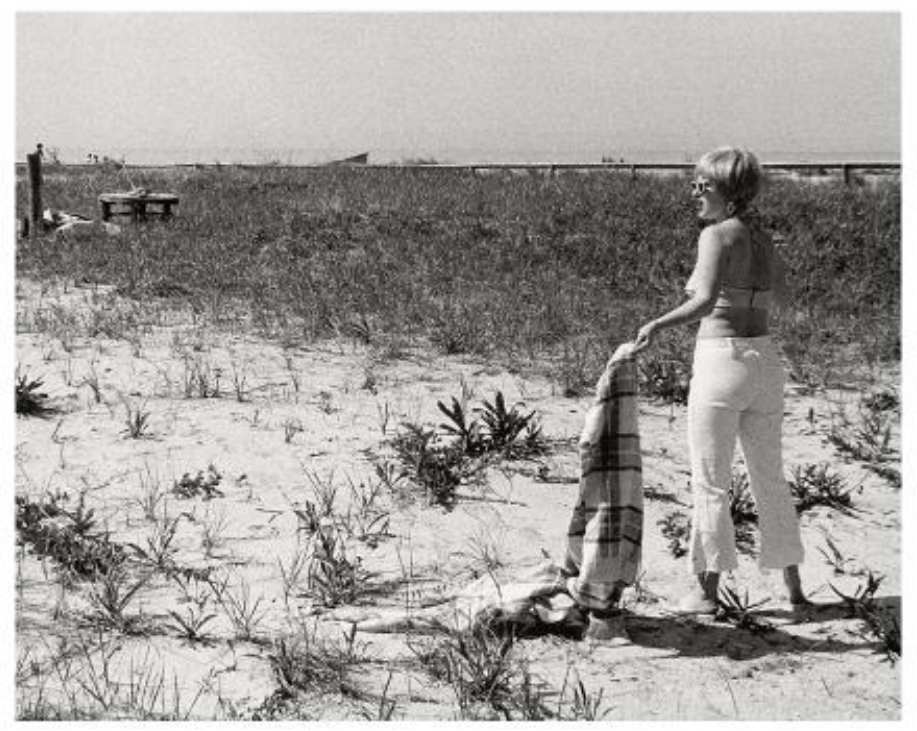

Cindy Sherman (1954),

Untitled Film Still \#09. 1978

152

$$
19,2 \times 24,1 \mathrm{~cm} \text {, Moma }
$$

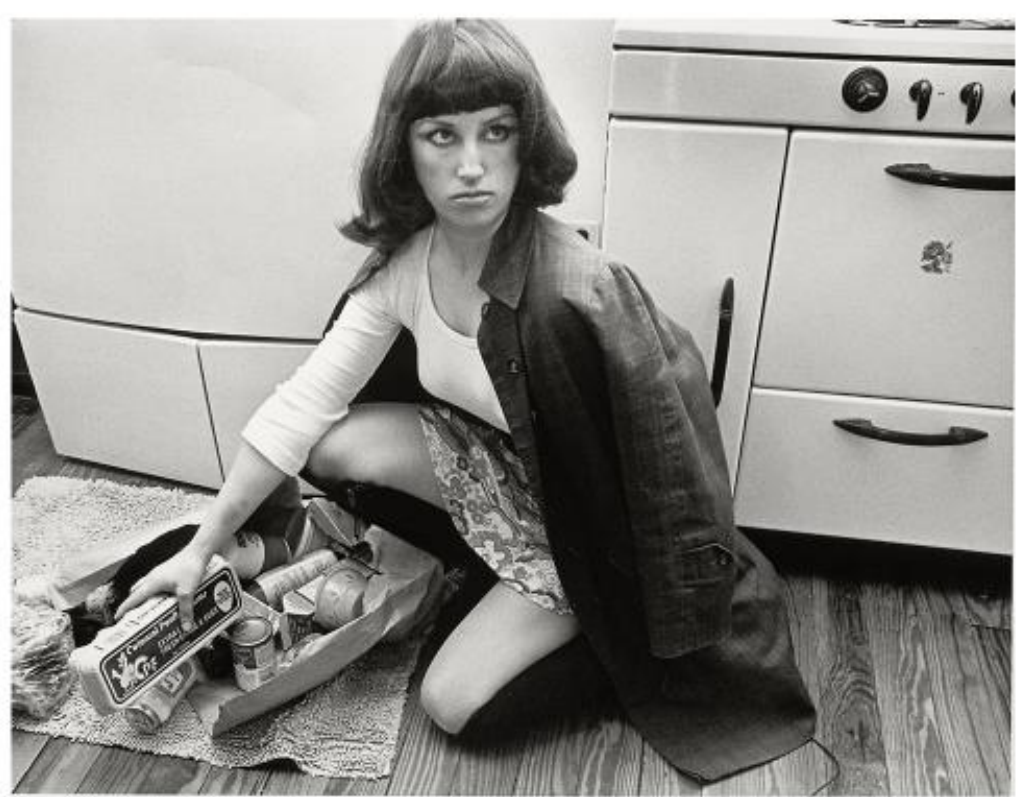

Cindy Sherman (1954),

Untitled Film Still \#10. 1978

153

$18,6 \times 24 \mathrm{~cm}$, Moma 


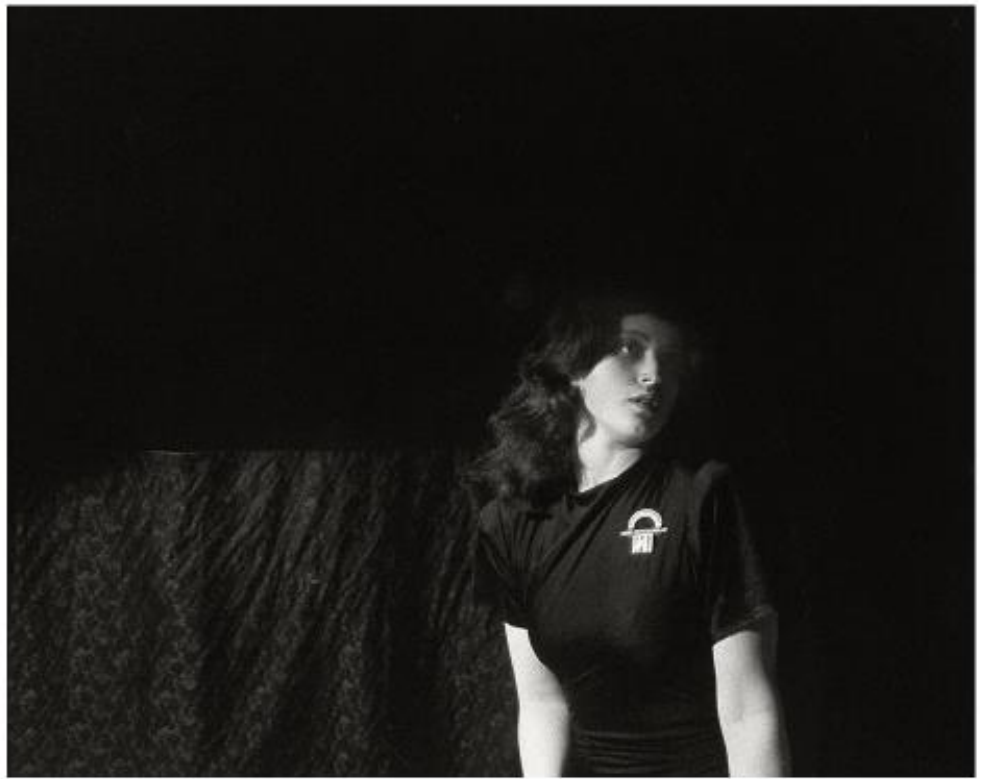

Cindy Sherman (1954),

Untitled Film Still \#31. $1979(19,2 \times 24 \mathrm{~cm})$

154 Moma

Cindy Sherman (1954),

Untitled Film Still \#7. 1978

$(24 \times 19,2 \mathrm{~cm})$

Moma

155 


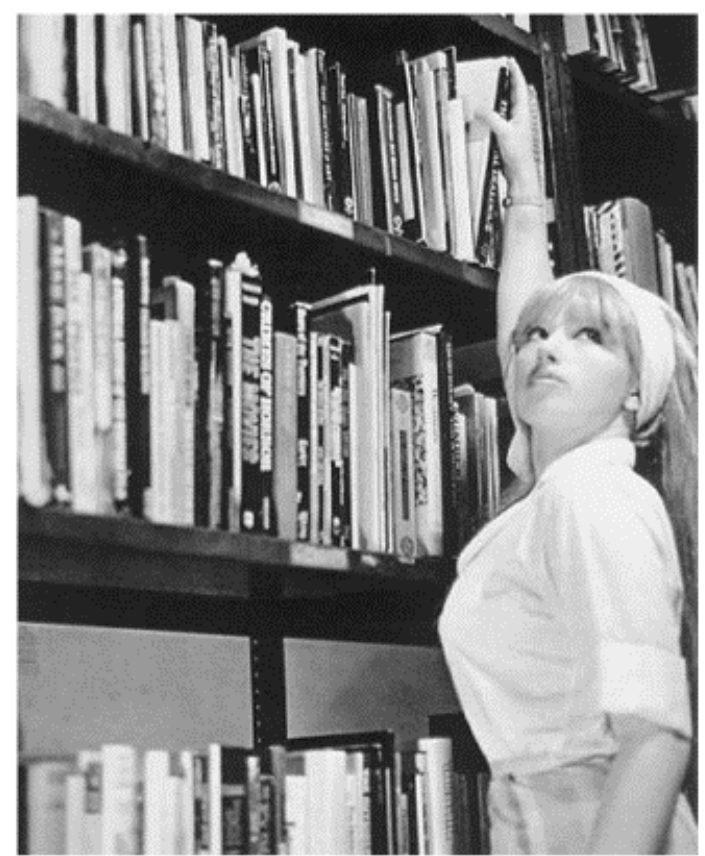

Cindy Sherman (1954),

Untitled Film Still \#13, 1978

156

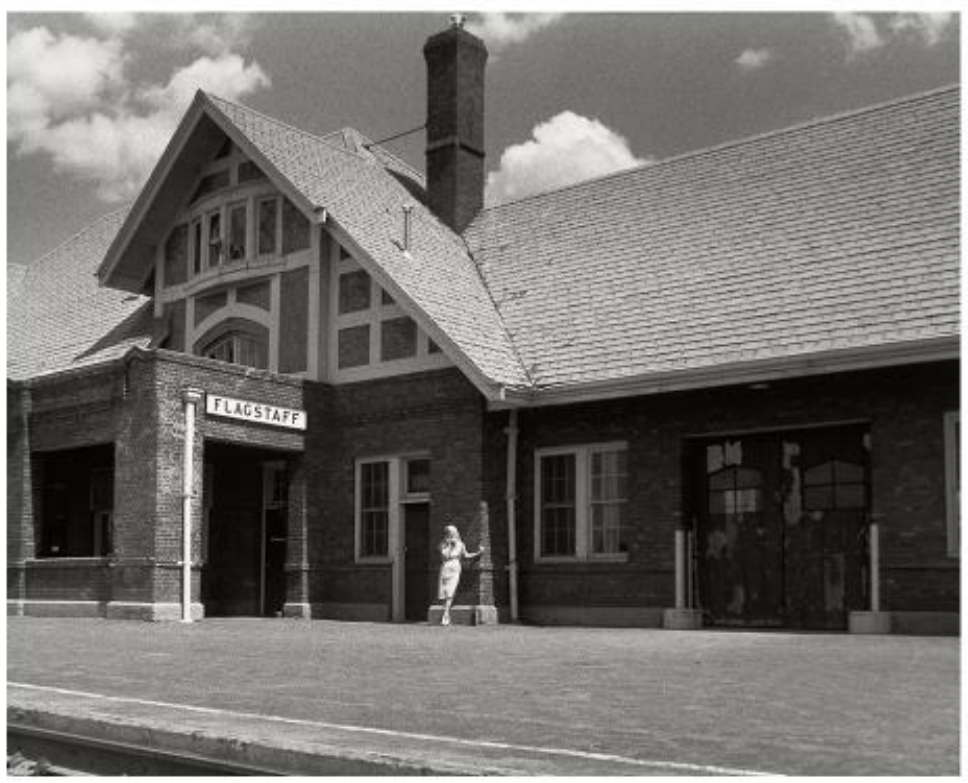

Cindy Sherman (1954), Untitled Film Still \#44, 1979

$(19,2 \times 24 \mathrm{~cm})$.

157 Moma 


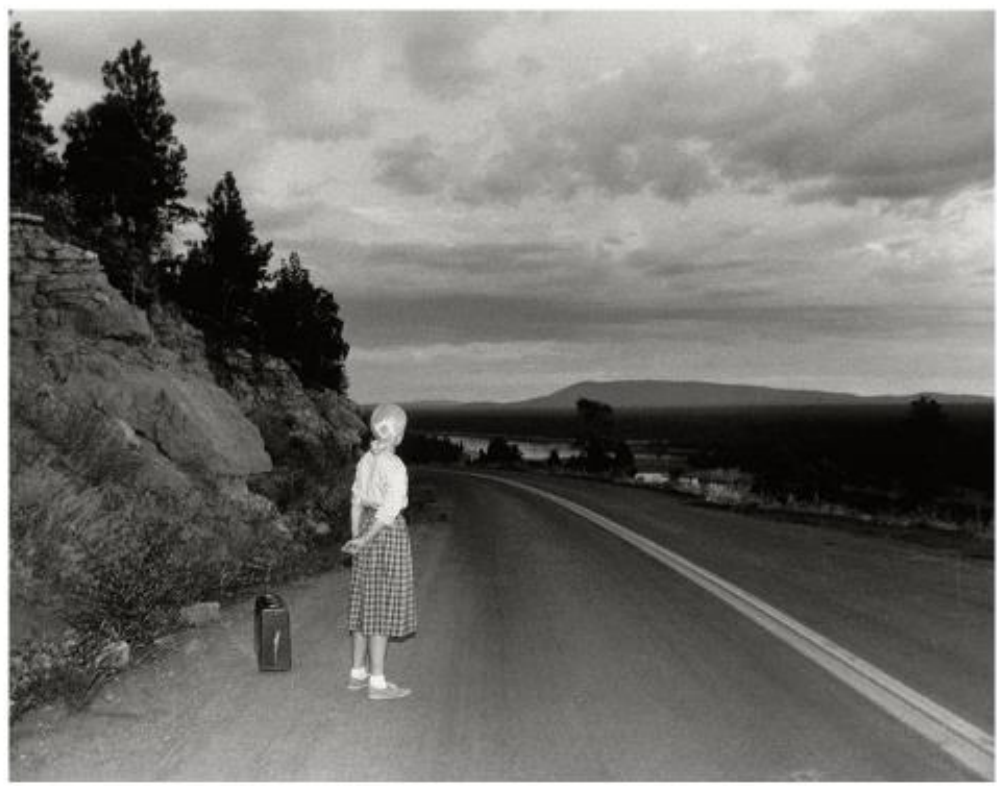

Cindy Sherman (1954), Untitled Film Still \#48. 1979 $(18,9 \times 24 \mathrm{~cm})$.

158 Moma

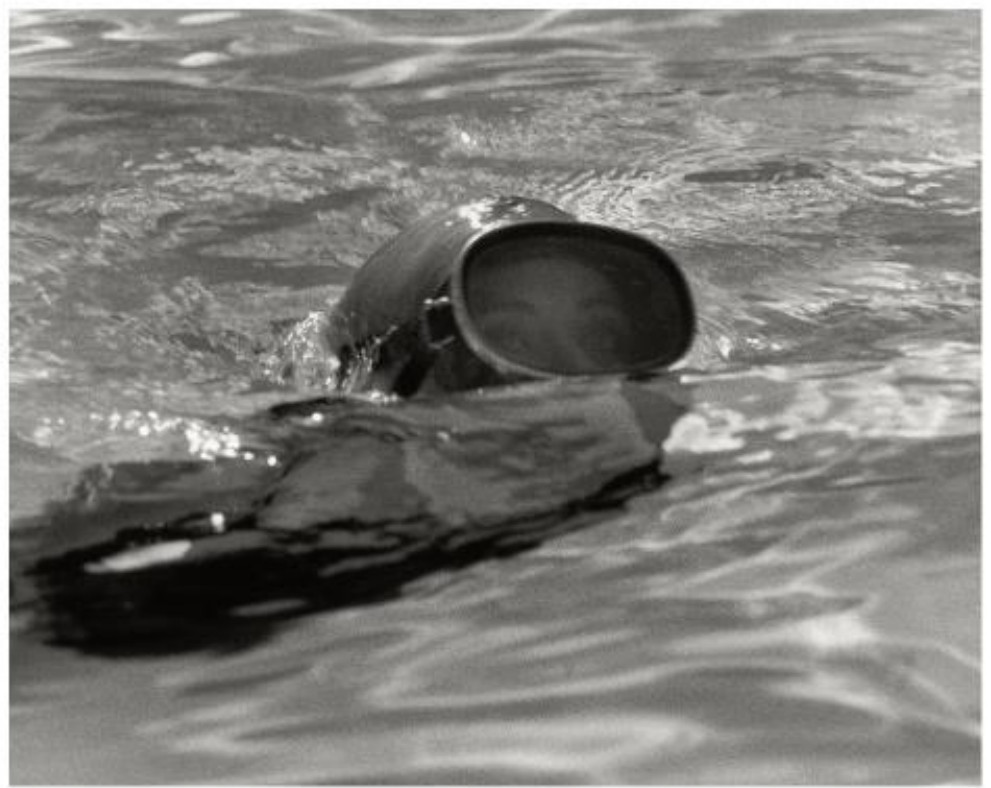

Cindy Sherman (1954), Untitled Film Still \#46. 1979

$(19,2 \times 24 \mathrm{~cm})$.

159

Moma 


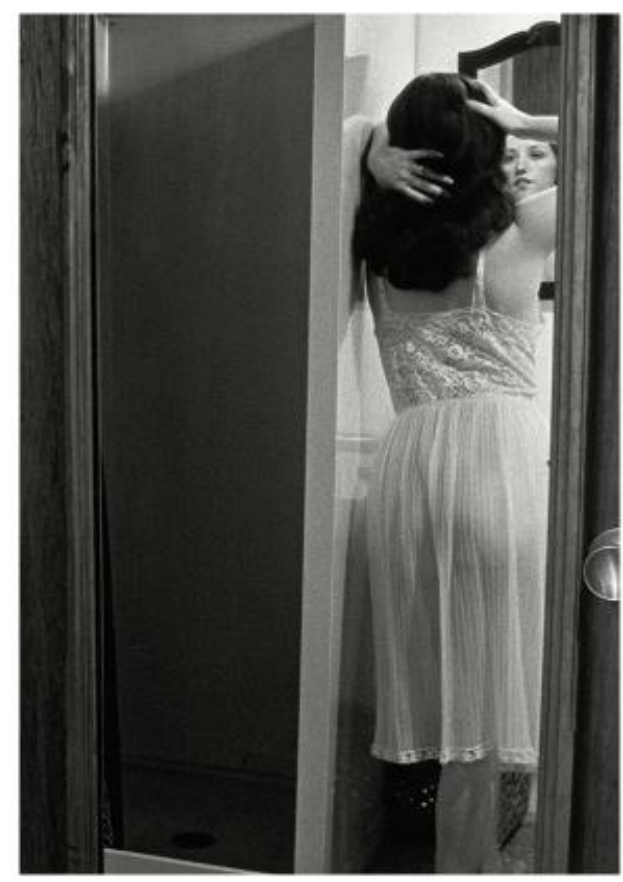

160

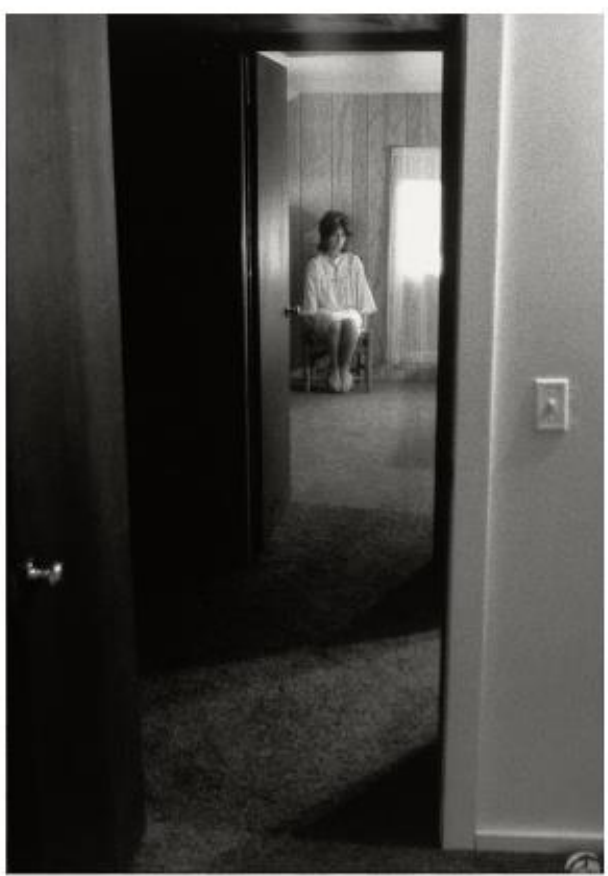

Cindy Sherman (1954),

Untitled Film Still \#81. 1980 $(24 \times 16,7 \mathrm{~cm})$.

Moma
Cindy Sherman (1954),

Untitled Film Still \#82. 1980 $(24 \times 16,7 \mathrm{~cm})$.

Moma 


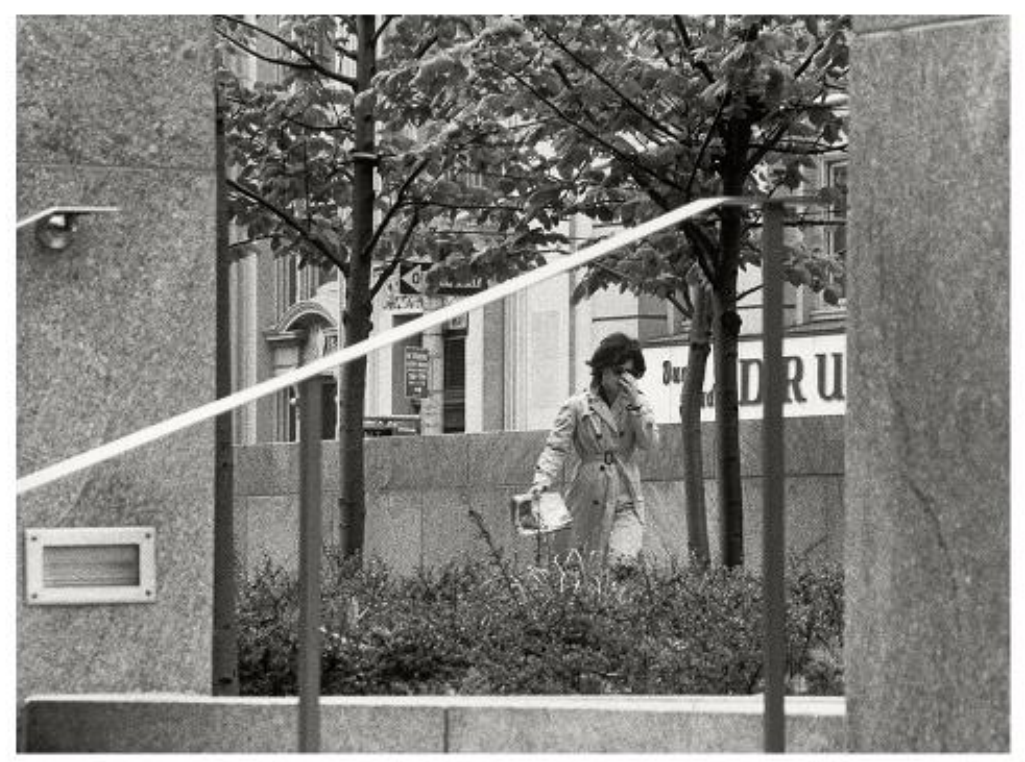

Cindy Sherman (1954), Untitled Film Still \#83. 1980 $(17,9 \times 24 \mathrm{~cm})$.

162 Moma

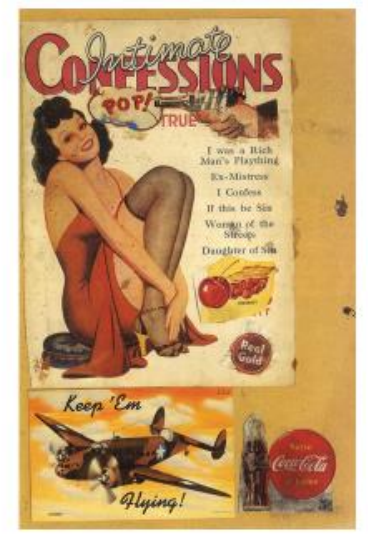

Eduardo Paolozzi (1924-2005):

I Was a Rich Man's Plaything (1947)

De Ten Collages from BUNK (1947-52

Colagem sobre cartão, $35,9 \times 23,8 \mathrm{~cm}$

Tate 

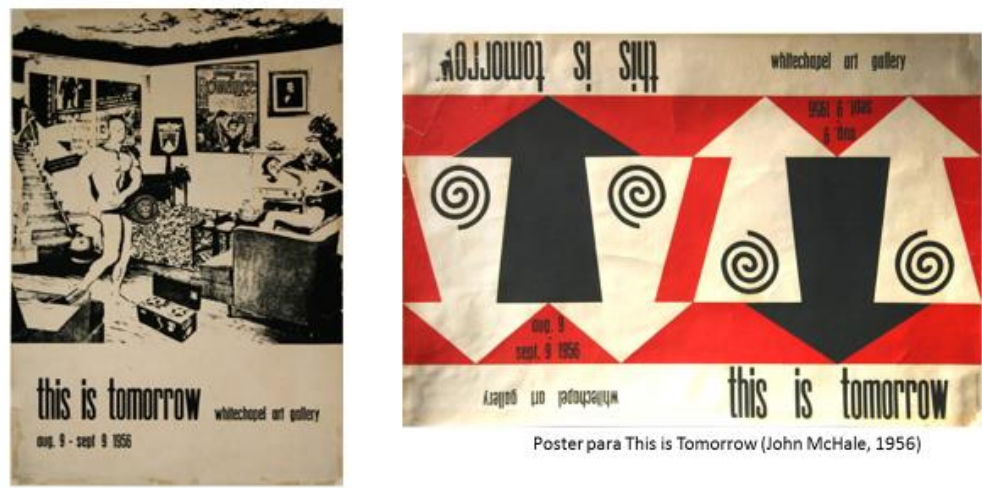

Poster para This is Tomorrow (Richard Hamilton, 1956)

164

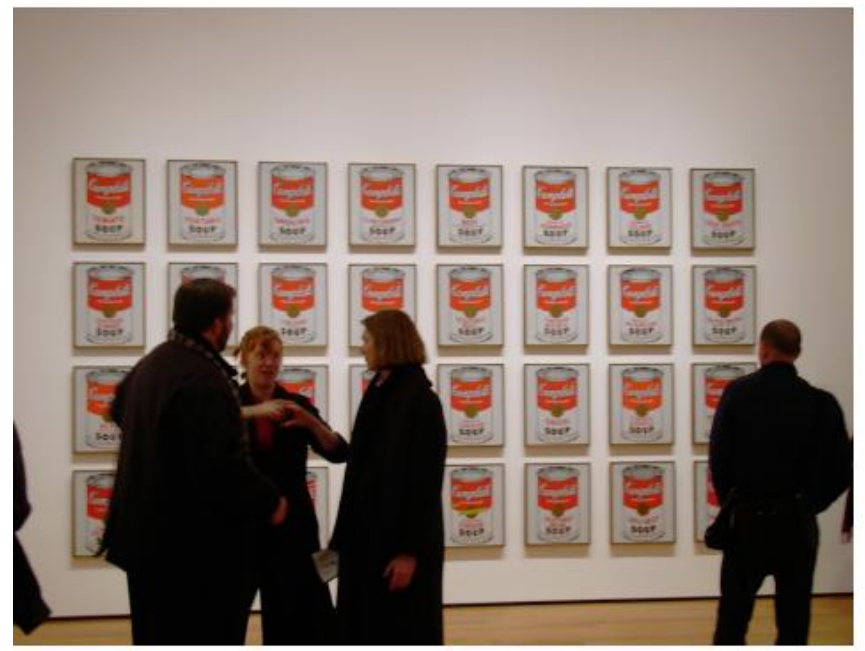

165

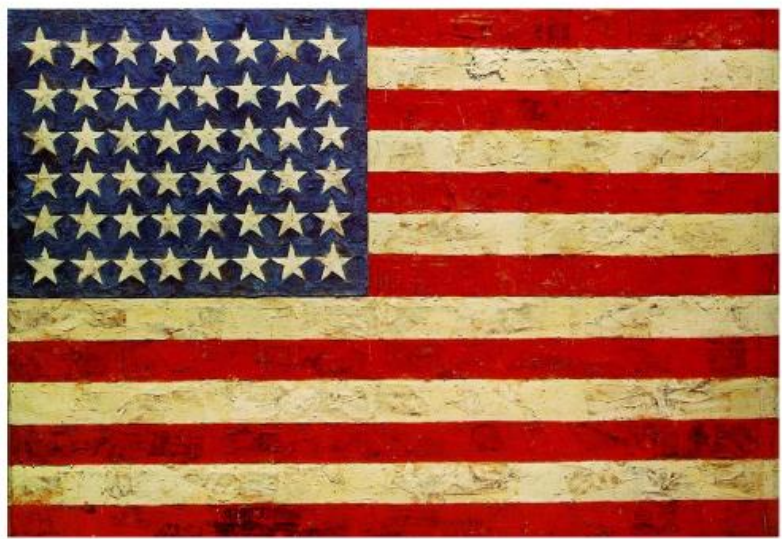

Jasper Johns (1930): Flag, 1954-55

Encáustica, óleo e colagem sobre tela montada sobre madeira compensada, três painéis Dimensões, $107,3 \times 153,8 \mathrm{~cm}$ 
167
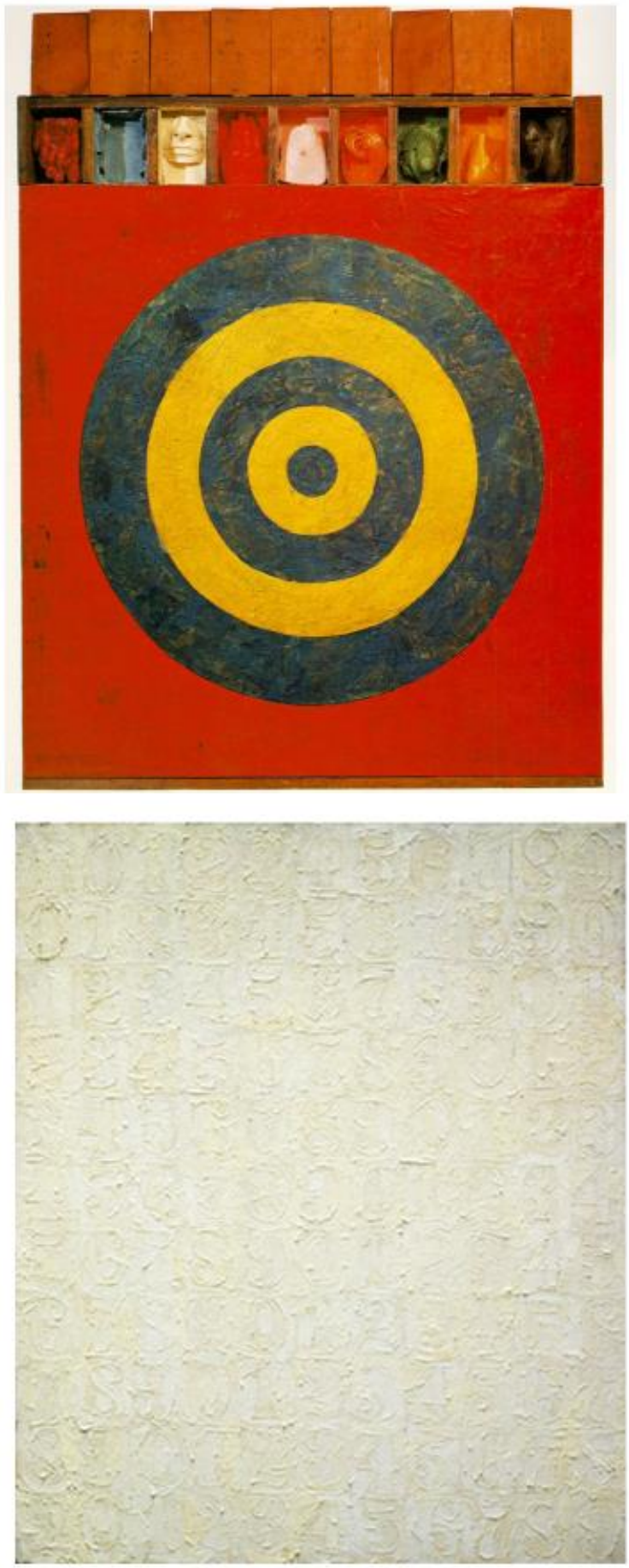

Jasper Johns (1930)

Target with Plaster Casts, 1955

$129.5 \times 111.8 \mathrm{~cm}$

Encáustica e colagem sobre tela com moldes de gesso pintadas Coleção de David Geffen, Los Angeles

\section{Jasper Johns}

White Numbers

1957. Encaustic on canvas, $(86.5 \times 71.3 \mathrm{~cm})$. 
